\author{
UNIVERSIDADE DE SÃO PAULO \\ FACULDADE DE FILOSOFIA, LETRAS E CIÊNCIAS HUMANAS \\ DEPARTAMENTO DE FILOSOFIA \\ PROGRAMA DE PÓS-GRADUAÇÃO EM FILOSOFIA
}

TOMÁS BASTIAN DE SOUSA

\title{
A CRÍTICA DA POLÍTICA EM MARX
}

da Questão Judaica à Crítica de Gotha 
TOMÁS BASTIAN DE SOUSA

\title{
A CRÍTICA DA POLIITICA EM MARX
} da Questão Judaica à Crítica de Gotha

\begin{abstract}
Tese apresentada ao Programa de PósGraduação em Filosofia da Faculdade de Filosofia Letras e Ciências Humanas da Universidade de São Paulo, para obtenção do título de Doutor em Filosofia sob a orientação do Prof. Dr. Milton Meira do Nascimento.
\end{abstract}


À Lua, minha pequena gigante, que na vida me ensina mais que qualquer livro 


\section{AGRADECIMENTOS}

Ao professor Milton Meira do Nascimento, meu orientador, pela confiança, pelo apoio e pela compreensão das minhas dificuldades de saúde.

À professora Lívia Cotrim, pelos esclarecimentos teóricos, pelo permanente estímulo e pelo acompanhamento do meu processo de pesquisa.

Aos professores Lincoln Secco e Carlos Toledo, pela compreensão das minhas dificuldades de saúde, pelo estímulo e pela disponibilidade de participar da banca de defesa.

À professora Vera Lucia Vieira, pela disponibilidade de participar da banca de defesa.

À Geni e à Mariê, pela compreensão das minhas dificuldades de saúde e pelo auxílio com os trâmites burocráticos que viabilizaram a continuidade dessa pesquisa.

À minha mãe, Maria Helena, e às minhas irmãs, Manuela e Roberta, pela compreensão das minhas dificuldades de saúde e pela garantia da estrutura material que me permitiu terminar essa pesquisa.

À Soraia, pela amizade, pelas conversas intermináveis e pelo estímulo constante.

À Ana e à Vera, amigas eternas, pelo apoio e incentivo permanentes, sem os quais esse doutorado não teria chegado ao fim.

Pesquisa realizada com o apoio da CAPES. 


\section{RESUMO}

SOUSA, Tomás Bastian de. A crítica da política em Marx: da Questão Judaica à Crítica de Gotha. 2016. $201 \mathrm{f}$. Tese (Doutorado) - Faculdade de Filosofia, Letras e Ciências Humanas. Departamento de Filosofia, Universidade de São Paulo, São Paulo, 2016.

A crítica de Marx à política, embora esparsa em seus escritos, possui um caráter bem definido e coerente, que se mantém ao longo de toda a sua obra desde a Questão Judaica (1843) até a Crítica de Gotha (1875). Essa pesquisa tem como objetivo apresentar, em seu conjunto, os principais aspectos dessa crítica. Começamos com a análise de seu princípio fundamental, a identificação da sociedade civil como base real do Estado, e a determinação do vínculo orgânico existente entre o Estado e a propriedade privada. Em seguida, passamos à crítica do Estado moderno, a partir de suas duas formas extremas: a forma bonapartista, que explicita a natureza do Estado como máquina de escravização do trabalho pelo capital, e a forma democrática, denunciada em seus limites intrínsecos e identificada como grau máximo de liberdade sob a dominação do capital. Seguimos com a crítica do direito, que atinge tanto o seu conteúdo quanto a sua forma, incluindo os direitos humanos. Passamos então à crítica da superstição política, isto é, às ilusões políticas teóricas e práticas, que abarcam desde as robinsonadas contratualistas às ilusões dos estadistas e revolucionários, com destaque para a crítica do viés democrático. Por fim, após explicitar a incompatibilidade radical entre política e liberdade humana e diferenciar a revolução meramente política da revolução social radical, chegamos à afirmação de uma nova qualidade de liberdade, para além da política, isto é, à abolição positiva da política, entendida como reabsorção das forças sociais usurpadas pelo Estado.

Palavras-chave: Marx, política, Estado, direito, liberdade. 


\begin{abstract}
SOUSA, Tomás Bastian de. Critique of politics in Marx: from On the Jewish Question to Critique of the Gotha Programme. 2016. $201 \mathrm{f}$. Thesis (Doctoral) - Faculdade de Filosofia, Letras e Ciências Humanas. Departamento de Filosofia, Universidade de São Paulo, São Paulo, 2016.

Marx's critique of politics, though spread throughout his writings, has a well-defined and coherent character that remains constant in all his work, from On the Jewish Question (1843) to Critique of the Gotha Programme (1875). This research aims to present the leading aspects of that critique as a whole. We start from the analysis of its main principles, namely the identification of civil society as the real base of State, and the organic connection between State and private property. Then we focus on the critique of modern State in both its extreme forms: the Bonapartist form, that accounts for the nature of the State as a slavering machine of labour by capital; and the democratic form, unveiled in its inherent limits and identified as the highest level of liberty under domination of capital. After that we turn to the critique of Right, which aims both its content and its form, including human rights. Then we approach the critique of political superstition, i.e., both theoretical and practical political illusions, that comprises a wide range of notions, from the contractualist robinsonades to the statesmen's and revolutionaries' illusions, with special emphasis on the critique of the democratic bias. At last, after clarifying the irreconcilability between politics and human liberty, and distinguishing between merely political revolution and radical social revolution, we get to the claim of a new quality of liberty, beyond politics, which means the positive suppression of politics, understood as reabsorption of social forces usurped by the State.
\end{abstract}

Keywords: Marx, Politics, State, Right, Liberty. 
o homem é mais infinito que o cidadão e a vida humana mais infinita que a vida política Karl Marx 


\section{SUMÁRIO}

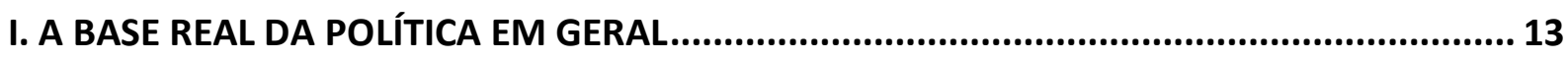

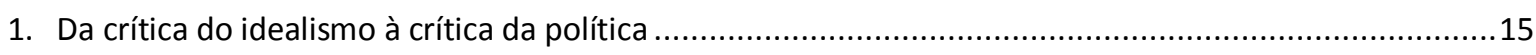

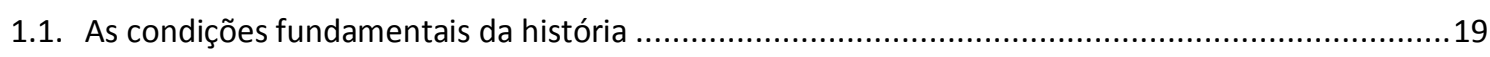

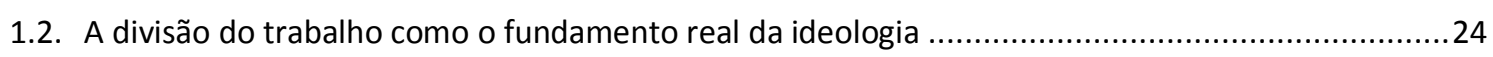

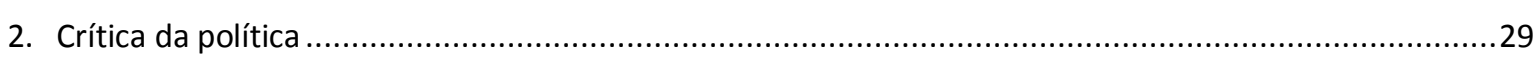

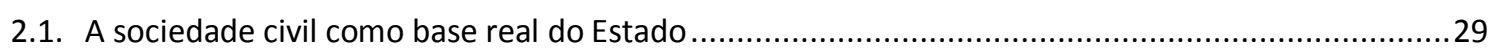

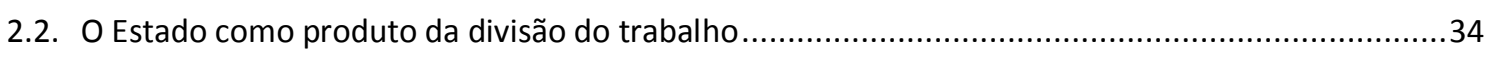

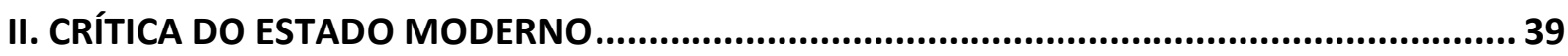

1. O vínculo orgânico entre o Estado e a propriedade privada ................................................................ 41

2. A substância do Estado: escravização do trabalho pelo capital ...........................................................46

3. Os limites intrínsecos da liberdade política: crítica do Estado democrático ............................................56

4. O Estado parasita: o poder político como força social usurpada ..........................................................64

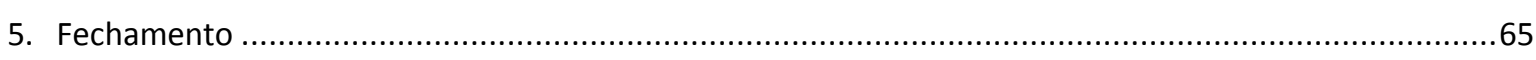

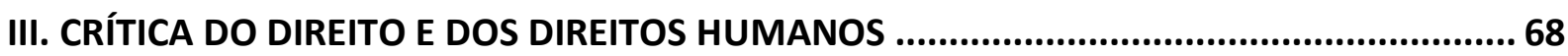

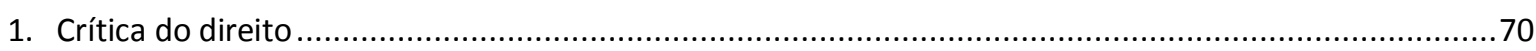

1.1. O conteúdo do direito: propriedade privada, dominação de classe e força .....................................72

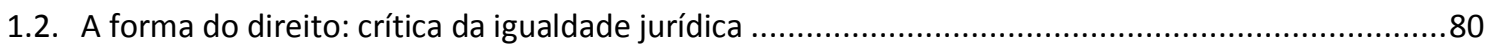

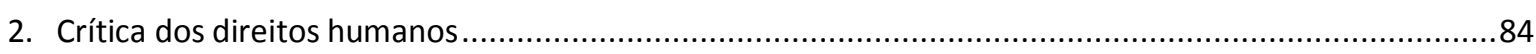

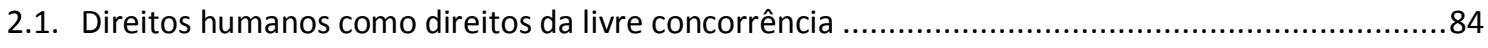

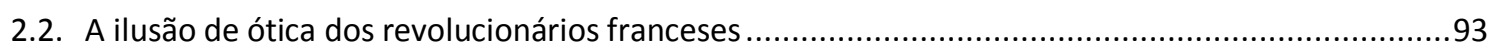

2.3. Contradição entre teoria e prática dos direitos do homem ...........................................................96

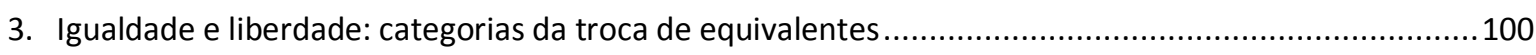

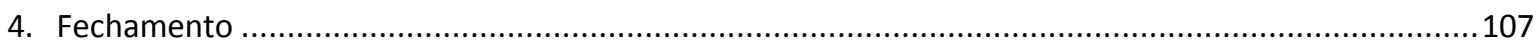

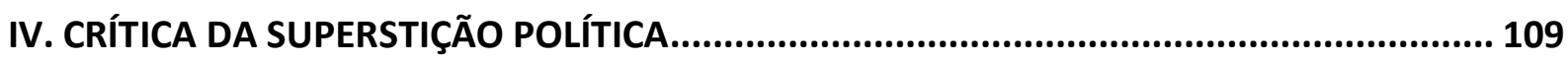

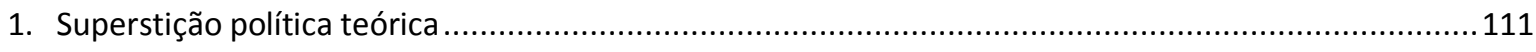

1.1. Crítica do ponto de vista do indivíduo isolado: as robinsonadas................................................111

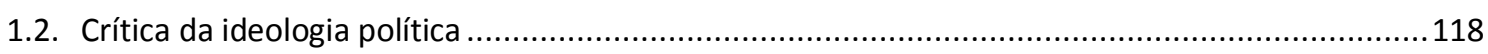

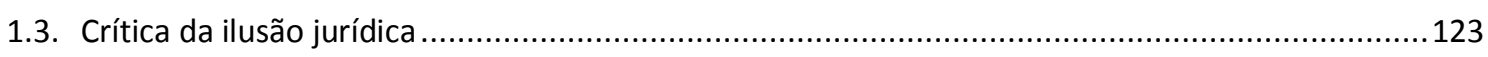

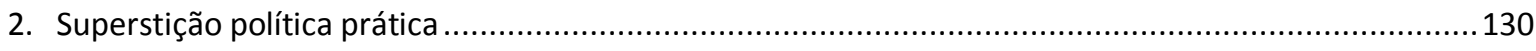

2.1. A ilusão dos estadistas: a impotência do Estado frente aos males sociais.....................................130

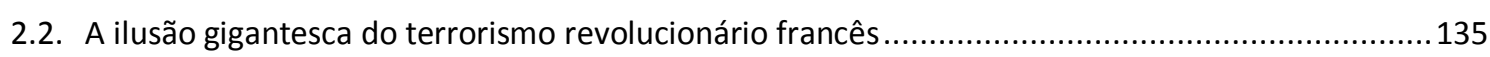

2.3. Crítica do viés democrático: as ilusões do proletariado e da pequena-burguesia ............................ 138

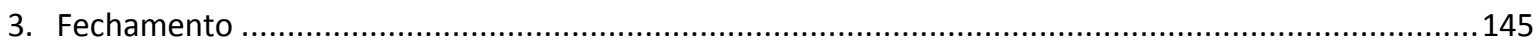


V. POLÍTICA E EMANCIPAÇÃO HUMANA .............................................................. 147

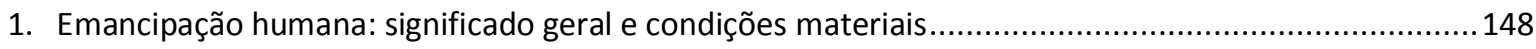

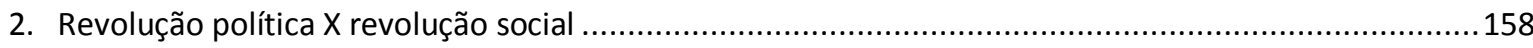

3. O momento político da revolução social: a ditadura do proletariado …………………………...........162

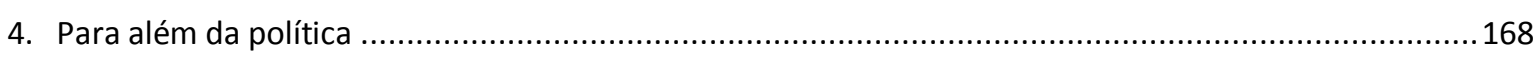

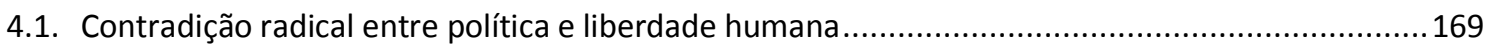

4.2. Abolição positiva da política: reabsorção das funções legítimas pelo corpo social..........................172

4.3. A Comuna de Paris: forma política não estatal e reabsorção das forças sociais .............................178

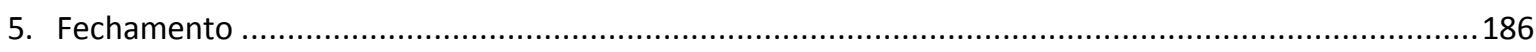

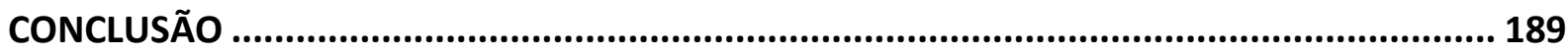

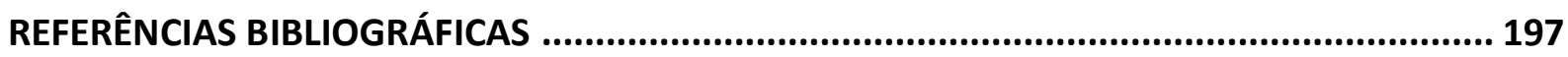




\section{APRESENTAÇÃO}

Essa pesquisa se apresenta como uma contribuição ao projeto teórico criado pelo filósofo brasileiro José Chasin, que tem como eixo principal a redescoberta de Marx, através da análise imanente de seus escritos. Neste sentido, busca desenvolver uma das determinações fundantes do pensamento original de Marx, aquela que diz respeito à política, designada por Chasin como determinação ontonegativa da politicidade - que, em uma palavra, significa a identificação da política como um atributo não necessário, e portanto contingente, à vida social. ${ }^{1}$

Sem a pretensão de esgotar a totalidade de sua obra, foram considerados como objeito de análise desta pesquisa os escritos de Marx compreendidos entre a Questão Judaica (1843) e a Crítica ao Programa de Gotha (1875). Embora a Crítica da Filosofia do Direito de Hegel represente, de fato, o ponto de virada na concepção de Marx acerca da política, especialmente pela determinação da sociedade civil como base do Estado e pela crítica da abstração do Estado moderno, em vários aspectos ela não é conclusiva, como por exemplo pela sustentação da "verdadeira democracia", que será completamente abandonada na sua obra posterior. ${ }^{2}$ Isso significa que o seu novo posicionamento sobre a política só se consuma na Questão Judaica, escrita logo em seguida, ainda no final de 1843. Por isso tomamos este texto, e não a Crítica, como o ponto de partida.

Um dos resultados mais evidentes desse estudo é a demonstração de que a crítica de Marx à política, embora se encontre esparsa ao longo de seus escritos, possui um caráter bem definido e coerente, que se mantém ao longo de toda a sua obra a partir da Questão Judaica, ainda que em diferentes graus de concretização. A falta de unidade na forma, nesse caso, é acompanhada de uma profunda unidade no conteúdo.

Trata-se, portanto, de um primeiro esforço no sentido de apresentar os principais aspectos da crítica de Marx à política em seu conjunto. Antes de tudo, no Capítulo 1, será

\footnotetext{
${ }^{1}$ A esse respeito, ver o texto de José Chasin "Marx: a determinação onto-negativa da politicidade" (Ensaios Ad Hominem, n. 1, tomo III, 2000).

${ }^{2}$ Sobre a incompletude da crítica da política na Crítica da Filosofia do Direito de Hegel e sobre o seu papel fundamental na trajetória intelectual de Marx, ver o capítulo 2 do texto de José Chasin "Marx: Estatuto Ontológico e Resolução Metodológica" (Ensaio, 1995) e as seguintes dissertações de mestrado realizadas sob a sua orientação: Leonardo Gomes de Deus, "Soberania Popular e Sufrágio Universal: o pensamento político de Marx na Crítica de 43" (FAFICH-UFMG, 2001); e Rúbens Moreira Enderle, "Ontologia e Política: a formação do pensamento marxiano de 1842 a 1846" (FAFICH-UFMG, 2000).
} 
feita a análise de seu princípio fundamental: a identificação da sociedade civil como a base real do Estado e das relações políticas e jurídicas em geral, princípio este conquistado na Crítica de 1843 e incansavelmente reafirmado por Marx ao longo de toda a sua obra, até o final de sua vida.

No Capítulo 2, após a identificação da propriedade privada desenvolvida como base real do Estado moderno, será analisada a crítica de Marx às duas formas extremas assumidas pelo Estado moderno: a forma bonapartista, que explicita a natureza do Estado enquanto máquina de guerra do capital contra o trabalho, e a forma democrática, denunciada em seus limites intrínsecos e intransponíveis, e identificada como o grau máximo de emancipação possível dentro da sociedade capitalista.

No Capítulo 3, analisaremos a crítica de Marx ao direito: partindo da indissociabilidade entre direito e propriedade privada, o direito será criticado tanto em geral quanto na sua forma mais desenvolvida, o direito burguês. Serão denunciados seus limites intrínsecos, tanto no que se refere ao seu conteúdo, enquanto expressão da vontade da classe dominante, quanto à sua forma, que se realiza necessariamente como desigualdade real. A crítica ao direito se estende também aos direitos humanos e, especialmente, às categorias de liberdade e igualdade, identificadas como produtos necessários e indissociáveis da relação de troca de mercadorias.

No Capítulo 4, analisaremos a crítica de Marx à superstição política, o que envolve a crítica das ilusões teóricas e práticas, tanto da burguesia como da classe trabalhadora, a respeito da política. Partiremos da crítica de Marx ao ponto de vista do indivíduo isolado, comum aos contratualistas e aos economistas clássicos, passando pela crítica da ideologia política e da ilusão jurídica, características dos filósofos alemães e dos juristas, para chegarmos à crítica das ilusões políticas práticas, denunciadas por Marx tanto na atuação de governantes como Napoleão e Frederico Guilherme IV, e dos revolucionários franceses da Convenção, quanto nos movimentos da classe trabalhadora, especialmente nas jornadas de 1848.

Por fim, no Capítulo 5, será analisada a relação entre política e emancipação humana. $\mathrm{Na}$ primeira parte, serão expostos o significado geral e as condições materiais da emancipação humana de acordo com Marx. Na segunda, partiremos da diferenciação entre revolução política e revolução social, demonstrando o sentido preciso do incontornável 
momento político da revolução social, mais conhecido como ditadura revolucionária do proletariado; passaremos pela incompatibilidade radical entre política e liberdade humana; chegando à perspectivação de uma nova qualidade de liberdade, para além da política, ou seja, à perspectiva da abolição positiva da política, no sentido de reabsorção das forças sociais usurpadas pelo Estado. Para encerrar o capítulo, traremos à tona as análises de Marx sobre a Comuna de Paris, identificada como a forma política da emancipação humana e, portanto, como um primeiro passo no processo de reabsorção das forças sociais pelo corpo da sociedade. 


\title{
I. A BASE REAL DA POLÍTICA EM GERAL
}

O ponto de partida fundamental da crítica de Marx à política é a afirmação de que o Estado e as relações políticas e jurídicas em geral não podem ser compreendidos a partir de si mesmos, como seres autônomos, mas apenas a partir de sua base real, ou seja, da sociedade civil, das relações sociais reais que formam a base da existência humana em cada período, portanto do modo de produção da vida, que tem como base a produção da vida material. Esse princípio fundamental é enunciado por Marx em seu famoso Prefácio de 1859 a Para a Crítica da Economia Política:

\begin{abstract}
"relações jurídicas, tais como formas de Estado, não podem ser compreendidas nem a partir de si mesmas, nem a partir do assim chamado desenvolvimento geral do espírito humano, mas, pelo contrário, elas se enraízam nas relações materiais de vida, cuja totalidade foi resumida por Hegel sob o nome de 'sociedade civil' (bürgerliche Gesellschaft), seguindo os ingleses e franceses do século XVIII; mas que a anatomia da sociedade burguesa (bürgerliche Gesellschaft) deve ser procurada na Economia Política. [...] na produção social da própria vida, os homens contraem relações determinadas, necessárias e independentes de sua vontade, relações de produção estas que correspondem a uma etapa determinada de desenvolvimento das suas forças produtivas materiais. A totalidade destas relações de produção forma a estrutura econômica da sociedade, a base real sobre a qual se levanta uma superestrutura jurídica e política, e à qual correspondem formas sociais determinadas de consciência. O modo de produção da vida material condiciona o processo em geral de vida social, política e espiritual” (Prefácio de 1859, p. 29-30).
\end{abstract}

Assim como as formas de consciência, as relações políticas só podem ser compreendidas a partir de sua base real, ou seja, das relações materiais de vida, do modo de produção da vida material. Esse princípio fundamental, cujo embrião se encontra já na Crítica da Filosofia do Direito de Hegel ${ }^{3}$, permanece explicitamente e se consolida como o princípio fundamental da crítica de Marx à política, recebendo consideráveis retomadas, aprofundamentos e concretizações ao longo de toda a sua obra até o final de sua vida. É na

\footnotetext{
${ }^{3}$ Embora já esteja claro o princípio fundamental de que é a sociedade civil que cria o Estado e não o inverso, é preciso enfatizar que a Crítica de 1843 ainda é inconclusiva no que se refere à crítica da política. A Questão Judaica, de fato, completa a virada crítica, mas a verdade é que esse resultado indicado por Marx no Prefácio de 1859 só vai aparecer explicitado dessa maneira pela primeira vez na Ideologia Alemã.
} 
Ideologia Alemã onde encontraremos as formulações mais ricas e completas sobre o assunto. Neste capítulo, portanto, serão explorados os vários aspectos desse princípio geral da crítica de Marx à política, tendo como eixo a análise da Ideologia Alemã.

Como é sabido, o tema principal da Ideologia Alemã é a crítica do idealismo neohegeliano. Entretanto, embora seu alvo imediato sejam os filósofos alemães da época, a crítica de Marx atinge não apenas toda a tradição filosófica idealista, como também toda a tradição materialista, isto é, os "empiristas ainda abstratos", "os ingleses e os franceses", e também Feuerbach. Desde a Crítica da Filosofia do Direito de Hegel, sob forte influência de Feuerbach, Marx rechaça a especulação hegeliana e estabelece como ponto de partida o ser objetivo, sensível. Com isso, Marx se insere na tradição do materialismo, mas desde o início de maneira crítica, embora isso ainda não esteja explicitado e embora Marx ainda esteja preso ao vocabulário neo-hegeliano ${ }^{4}$. É só na Ideologia Alemã e nas Teses Ad Feuerbach que Marx desenvolve explicitamente a sua crítica a Feuerbach e aos chamados "empiristas ainda abstratos". Se, contra os idealistas, Marx enfatiza o caráter sensível e objetivo da natureza, dos homens e da atividade humana, contra Feuerbach e os empiristas ainda abstratos Marx enfatiza o caráter ativo dos homens, a atividade de produção do mundo objetivo, atividade que é igualmente objetiva.

Podemos dizer que o mote principal da Ideologia Alemã é a sustentação de que a atividade prática de produção da vida é o fundamento de toda existência humana. E, se este é o princípio da crítica de Marx ao idealismo, é preciso enfatizar que este é também o princípio de sua crítica da política. Embora não receba o mesmo detalhamento que a crítica do idealismo, a crítica da política é um tema igualmente importante para Marx na Ideologia Alemã. Podemos dizer que ela é o segundo grande motivo do texto. E, se a crítica ao idealismo é voltada contra os filósofos neo-hegelianos, isto é, os "alemães", a crítica da política é dirigida principalmente contra os "ingleses e franceses".

\footnotetext{
${ }^{4}$ Nas palavras do próprio Marx: "Esta evolução era já indicada nos Anais franco-alemães, na Introdução à Crítica da Filosofia do Direito de Hegel e na Questão Judaica. Mas estava ainda na dependência do vocabulário filosófico tradicional, e os termos filosóficos tradicionais contidos nessas obras, tais como 'essência humana', 'gênero', etc., deram aos teóricos alemães a desejada oportunidade para desprezar o verdadeiro sentido e para crer que se tratava de uma nova transformação das suas usadas vestes teóricas [...]" (Ideologia Alemã, v. I, p. 306).
} 
Aqui, acompanharemos os momentos fundamentais da crítica de Marx ao idealismo, para em seguida desenvolver os aspectos principais de sua crítica à política.

\title{
1. Da crítica do idealismo à crítica da política
}

\begin{abstract}
"A missão da história consiste, pois, já que desapareceu o além da verdade, em descobrir a verdade do aquém. Em primeiro lugar, a missão da filosofia que está a serviço da história, consiste, uma vez que foi desmascarada a forma sacra da auto-alienação humana, em desmascarar a autoalienação em suas formas profanas. A crítica do céu transforma-se, com isto, em crítica da terra, a crítica da religião na crítica do direito, a crítica da teologia na crítica da política" (Introdução à Crítica da Filosofia do Direito de Hegel, p. 2).
\end{abstract}

A Ideologia Alemã foi redigida por Marx, juntamente com Engels, de outubro de 1845 a maio de 1846, e constitui um volumoso manuscrito, que veio a público somente em 1932. Como indica o longo subtítulo da obra - crítica da mais recente filosofia alemã representada por Feuerbach, B. Bauer e Stirner, e do socialismo alemão representado por seus diferentes profetas -, a Ideologia Alemã é uma crítica do conjunto da filosofia pós-hegeliana da época. Nas palavras de Marx no Prefácio de 1859, trata-se de um "acerto de contas com a nossa consciência filosófica anterior". Diante das dificuldades em publicar os seus "dois grossos volumes", Marx e Engels decidem abandonar o manuscrito à "crítica roedora dos ratos", uma vez que "já havíamos atingido o fim principal: a auto-compreensão" (Prefácio de 1859, p. 31).

Na Ideologia Alemã, mais especificamente no capítulo I, intitulado "Feuerbach", encontramos a apresentação positiva dos princípios de Marx e Engels ${ }^{5}$, já prometida na introdução da Sagrada Família. Essa apresentação é caracterizada pelos autores como "algumas considerações gerais", que "serão suficientes para caracterizar o ponto de vista de nossa crítica, na medida em que isto seja necessário para a compreensão e fundamentação das críticas individuais subsequentes" (Ideologia Alemã, p. 23). E, explicando por que a

\footnotetext{
${ }^{5}$ Vale enfatizar que o objeto deste trabalho é o pensamento de Marx, e não o de Engels. E, por mais que o texto seja assinado por ambos, recusamos qualquer identificação a priori entre o pensamento dos dois autores.
} 
exposição dos seus princípios é realizada no capítulo sobre Feuerbach, acrescentam: “Contrapomos estas considerações a Feuerbach em especial porque este é o único que fez ao menos algum progresso e cujos escritos podem ser examinados de bonne foi [de boa fé]. Tais considerações esclarecerão melhor os pressupostos ideológicos comuns a todos eles" (Ideologia Alemã, p. 23).

O principal objetivo de Marx no texto é desmascarar esses "pressupostos ideológicos comuns" que "formam o núcleo da atual filosofia neo-hegeliana" (Ideologia Alemã, p. 17). Este núcleo é sintetizado na seguinte passagem:

\begin{abstract}
"Todos os críticos filosóficos alemães afirmam que os homens reais têm sido até aqui dominados e determinados por ideias, representações e conceitos, que o mundo real é um produto do mundo ideal. Isso, que tem acontecido até o presente instante, deve, entretanto, modificar-se. Tais críticos diferenciam-se entre si pela maneira através da qual pretendem libertar o mundo dos homens, que, segundo eles, tanto sofre sob o peso de seus próprios pensamentos fixos; concordam na crença do domínio dos pensamentos; concordam na crença de que seu ato de pensar crítico levará, fatalmente, à destruição do estado de coisas existente [...]" (Ideologia Alemã, p. 18, suprimido do manuscrito).
\end{abstract}

Trata-se, portanto, de denunciar o idealismo característico dos jovens hegelianos, que, segundo Marx, além de não superar a filosofia de Hegel, ainda se apresenta como uma expressão empobrecida de seu pensamento. Porém, a crítica de Marx atinge não apenas os jovens hegelianos, mas também os velhos hegelianos, o próprio Hegel, todo o idealismo filosófico e toda forma de consciência invertida do mundo, desde a sua primeira manifestação, os sacerdotes. Ou seja, atinge "a ilusão dos ideólogos em geral" ou "a ideologia em geral".

O termo ideologia designa aqui o fundamento da posição idealista, isto é, a crença de que a consciência possui uma existência autônoma e determinante em relação ao mundo real e de que o mundo real é um produto do mundo ideal ${ }^{6}$.

O esforço central de Marx na Ideologia Alemã é justamente demonstrar que, ao contrário do que pensam os neo-hegelianos e os ideólogos em geral, a consciência é um produto das relações reais entre os homens e, enquanto tal, é determinada pelo seu

\footnotetext{
${ }^{6}$ Não é este o único sentido em que aparece o termo ideologia na obra de Marx. Além do sentido ontocrítico, há também o sentido ontodenominativo, que se refere a qualquer forma de consciência, seja ela idealista ou não. Para maiores detalhes, ver VAISMAN, Ester. "A Determinação Marxiana da Ideologia”, tese de doutorado, Belo Horizonte, Faculdade de Educação-UFMG, 1996.
} 
processo de vida real. Longe de possuir uma existência autônoma, a consciência é um dos predicados do ser social e só pode ser corretamente compreendida a partir dessa sua base real.

Essa determinação, segundo Marx, é válida para todos os produtos da consciência, inclusive as "formações nebulosas do cérebro dos homens". Assim, relembrando a Introdução de 1843, Marx reafirma que a inversão das formações ideais (como a religião, o idealismo filosófico e outras formas de ideologia) não é devida a um simples erro da subjetividade individual, mas sim a uma inversão real presente num determinado modo de vida prático dos homens.

Vale acompanhar na íntegra as conhecidas passagens de Marx sobre o assunto:

\begin{abstract}
"Os homens são os produtores de suas representações, de suas ideias etc., mas os homens reais e ativos, tal como se acham condicionados por um determinado desenvolvimento de suas forças produtivas e pelo intercâmbio que a ele corresponde até chegar às suas formações mais amplas. A consciência jamais pode ser outra coisa do que o ser consciente, e o ser dos homens é o seu processo de vida real. E se, em toda ideologia, os homens e suas relações aparecem invertidos como numa câmara escura, tal fenômeno decorre de seu processo histórico de vida, do mesmo modo por que a inversão dos objetos na retina decorre de seu processo de vida diretamente físico" (Ideologia Alemã, p. 36-37).
\end{abstract}

E, logo em seguida:

"Totalmente ao contrário do que ocorre na filosofia alemã, que desce do céu à terra, aqui se ascende da terra ao céu. Ou, em outras palavras: não se parte daquilo que os homens dizem, imaginam ou representam, e tampouco dos homens pensados, imaginados e representados para, a partir daí, chegar aos homens em carne e osso; parte-se dos homens realmente ativos e, partir de seu processo de vida real, expõe-se também o desenvolvimento dos reflexos ideológicos ${ }^{7}$ e dos ecos desse processo de vida. E mesmo as formações nebulosas no cérebro dos homens são sublimações necessárias do seu processo de vida material, empiricamente constatável e ligado a pressupostos materiais. A moral, religião, a metafísica e qualquer outra ideologia, assim como as formas de consciência que a elas correspondem, perdem toda a aparência de autonomia. Não têm história, nem desenvolvimento; mas os homens, ao desenvolverem sua produção material e seu intercâmbio material, transformam também, com esta sua realidade, seu pensar e os produtos de seu pensar. Não é a consciência que

\footnotetext{
${ }^{7}$ Eis um exemplo do sentido mais abrangente (ontodenominativo) do termo ideologia. Aqui, Marx se refere a qualquer produto da consciência humana, seja ele invertido ou não.
} 
determina a vida, mas a vida que determina a consciência. Na primeira maneira de considerar as coisas, parte-se da consciência como do próprio indivíduo vivo; na segunda, que é a que corresponde à vida real, parte-se dos próprios indivíduos reais e vivos, e se considera a consciência unicamente como sua consciência" (Ideologia Alemã, p. 37-38).

Nessas passagens, Marx condensa o núcleo de sua crítica ao idealismo neo-hegeliano e à ideologia em geral, que é o motivo que permeia a Ideologia Alemã do começo ao fim. No lugar do pensamento puro e da autoconsciência, surgem os indivíduos reais e ativos, o processo de vida real dos homens. Como é frequente no texto, Marx é enfático ao afirmar este seu ponto de partida:

"Os pressupostos de que partimos não são arbitrários, nem dogmas. São pressupostos reais de que não se pode fazer abstração a não ser na imaginação. São os indivíduos reais, sua ação e suas condições materiais de vida, tanto aquelas por eles já encontradas, como as produzidas por sua própria ação. Estes pressupostos são, pois, verificáveis por via puramente empírica." (Ideologia Alemã, p. 26-27).

E mais adiante:

“Esta concepção não é desprovida de pressupostos. Parte de pressupostos reais e não os abandona um só instante. Estes pressupostos são os homens, não em qualquer fixação ou isolamento fantásticos ${ }^{8}$, mas em seu processo de desenvolvimento real, em condições determinadas, empiricamente visíveis. Desde que se apresente este processo ativo de vida, a história deixa de ser uma coleção de fatos mortos, como para os empiristas ainda abstratos, ou uma ação imaginária de sujeitos imaginários, como para os idealistas" (Ideologia Alemã , p. 38). ${ }^{9}$

Para Marx, a "ciência real, positiva", o "saber real" só pode ser "a exposição da atividade prática, do processo prático de desenvolvimento dos homens" (Ideologia Alemã, p. 38), ou seja, o "estudo do processo de vida real e da vida dos indivíduos de cada época" (Ideologia Alemã, p. 39). Porém, na impossibilidade de desenvolver essa "exposição real", Marx afirma, com as devidas ressalvas, que é possível apresentar, "quando muito, um

\footnotetext{
${ }^{8}$ Referência ao estado de natureza idealizado pelos contratualistas e pela economia política. A crítica de Marx à concepção do indivíduo como naturalmente isolado, que ele ironicamente denomina de robinsonadas, será abordada com maior detalhe no Capítulo 4.

${ }^{9}$ Comparar com a I Tese sobre Feuerbach.
} 
resumo dos resultados mais gerais, que se deixam abstrair da consideração do desenvolvimento histórico dos homens". E, explicitando as ressalvas, continua:

\begin{abstract}
"Estas abstrações, separadas da história real, não possuem valor algum. Podem servir apenas para facilitar a ordenação do material histórico, para indicar a sequência de suas camadas singulares. Mas de forma alguma dão, como a filosofia [isto é, a filosofia especulativa alemã], uma receita ou um esquema onde as épocas podem ser enquadradas. [...] Destacaremos aqui algumas destas abstrações, para contrapô-las à ideologia, ilustrando-as com alguns exemplos históricos" (Ideologia Alemã, p. 38-39).
\end{abstract}

Com isso, Marx determina precisamente o sentido das considerações que fará em seguida, no item "História". São afirmações de ordem geral, um resumo geral, abstrações, que, embora isoladamente não tenham sentido, são capazes de evidenciar algumas "condições fundamentais de toda a história", "aspectos da atividade social [...] que coexistem desde os primórdios da história e desde os primeiros homens, e que ainda hoje se fazem valer" (Ideologia Alemã, p. 42).

\title{
1.1. As condições fundamentais da história
}

Segundo Marx,

"O primeiro pressuposto de toda história humana é naturalmente a existência de indivíduos humanos vivos. O primeiro fato a constatar é, pois, a organização corporal destes indivíduos e, por meio disto, sua relação dada com o resto da natureza. [...] Toda historiografia deve partir destes fundamentos naturais e de sua modificação no curso da história pela ação dos homens" (Ideologia Alemã, p. 27).

Para Marx, o homem é antes de tudo um ser objetivo, e um ser objetivo vivo. Como qualquer outro ser vivo, possui necessidades vitais. Para satisfazer essas necessidades, precisa estabelecer relações com o mundo exterior, ou seja, com o resto da natureza. Segundo Marx, o que diferencia o homem dos animais é o fato de ele produzir seus meios de vida e, com isso, produzir a sua própria vida material: 
"Pode-se distinguir os homens dos animais pela consciência, pela religião ou por tudo que se queira. Mas eles próprios começam a se diferenciar dos animais tão logo começam a produzir seus meios de vida, passo este que é condicionado por sua organização corporal. Produzindo seus meios de vida, os homens produzem, indiretamente, sua própria vida material" (Ideologia Alemã, p. 27).

O primeiro pressuposto de toda a história, para Marx, é a reprodução da existência física dos indivíduos, o que só é possível para os homens através da produção dos seus meios de vida e, consequentemente, da sua própria vida material. Assim, a base real da história é a própria atividade vital dos homens, isto é, o trabalho, a indústria, o intercâmbio material entre o homem e a natureza. Nas palavras de Marx,

\begin{abstract}
"o primeiro pressuposto de toda a existência humana e, portanto, de toda a história, é que os homens devem estar em condição de viver para poder 'fazer história'. Mas, para viver, é preciso antes de tudo comer, beber, ter habitação, vestir-se e algumas coisas mais. O primeiro ato histórico é, portanto, a produção dos meios que permitam a satisfação destas necessidades, a produção da própria vida material, e de fato este é um ato histórico, uma condição fundamental de toda a história, que ainda hoje, como há milhares de anos, deve ser cumprido todos os dias e todas as horas, simplesmente para manter os homens vivos. [...] A primeira coisa, portanto, em qualquer concepção histórica, é observar este fato fundamental em toda sua significação e em toda sua extensão e render-lhe toda justiça" (Ideologia Alemã, p. 39-40).
\end{abstract}

Em segundo lugar, Marx ressalta que essa produção dos meios de vida significa ao mesmo tempo a produção de novas necessidades:

"O segundo ponto é que, satisfeita esta primeira necessidade, a ação de satisfazê-la e o instrumento de satisfação já adquirido conduzem a novas necessidades - e esta produção de novas necessidades é o primeiro ato histórico" (Ideologia Alemã, p. 40).

Em terceiro lugar, Marx demonstra que os homens, além de produzir os meios necessários para a satisfação de suas necessidades através do trabalho, também produzem outros homens, isto é, procriam. Essa produção de outros homens através da procriação envolve necessariamente a relação entre vários indivíduos: 
"A terceira condição que já de início intervém no desenvolvimento histórico é que os homens, que diariamente renovam sua própria vida, começam a criar outros homens, a procriar: é a relação entre homem e mulher, entre pais e filhos, a familia" (Ideologia Alemã, p. 41).

Com isso, em quarto lugar, Marx constata o caráter necessariamente social da produção da vida humana, ou seja, o fato de que a produção da vida humana se dá necessariamente em sociedade:

"A produção da vida, tanto da própria, no trabalho, como da alheia, na procriação, aparece agora como dupla relação: de um lado, como relação natural, de outro como relação social - social no sentido de que se entende por isso a cooperação de vários indivíduos, quaisquer que sejam as condições, o modo e a finalidade" (Ideologia Alemã, p. 42).

Consequentemente, todo modo de produção está sempre associado a um determinado modo de cooperação ou, em outras palavras, toda fase industrial está sempre associada a um determinado estado social. Este modo de cooperação é condicionado pelo nível de desenvolvimento das forças produtivas, e ambos constituem o fundamento real de toda a vida humana e, portanto, de toda a história:

\begin{abstract}
"Donde se segue que um determinado modo de produção ou uma determinada fase industrial estão constantemente ligados a um determinado modo de cooperação e a uma fase social determinada, e que tal modo de cooperação é, ele próprio, uma 'força produtiva'; segue-se igualmente que a soma de forças produtivas acessíveis aos homens condiciona o estado social e que, por conseguinte, a 'história da humanidade' deve sempre ser estudada e elaborada em conexão com a história da indústria e das trocas" (Ideologia Alemã, p. 42).
\end{abstract}

Para Marx, a conexão social entre os indivíduos não é algo fortuito, que depende apenas da vontade dos indivíduos. Ao contrário, a cooperação entre os homens é determinada pela sua própria natureza, ou seja, pelas próprias necessidades e pelo modo de satisfazê-las (modo de produção da vida material). Sendo assim, trata-se de um aspecto necessário à vida humana. ${ }^{10} \mathrm{Em}$ crítica direta a Stirner, Marx afirma:

\footnotetext{
${ }^{10}$ Este é o fundamento da crítica de Marx à ideia comum aos contratualistas de um estado de natureza em que o homem viveria isolado dos demais, numa suposta independência original. Como já foi anunciado, esse tema será retomado com maior detalhe no Capítulo 4.
} 
“Os indivíduos 'partiram', sempre e em quaisquer circunstâncias, 'deles próprios', mas eles não eram únicos no sentido de que não poderiam deixar de ter relações entre si; pelo contrário, suas necessidades, portanto a sua natureza, e a maneira de as satisfazer, tornava-os dependentes uns dos outros (relações entre os sexos, trocas, divisão do trabalho); era portanto inevitável que se estabelecessem relações entre eles" (Ideologia Alemã, v. II, p. 300).

Em outras palavras:

\begin{abstract}
"Desde o início mostra-se, portanto, uma conexão materialista dos homens entre si, condicionada pelas necessidades e pelo modo de produção, conexão esta que é tão antiga quanto os próprios homens - e que toma, incessantemente, novas formas e apresenta, portanto, uma 'história', sem que exista qualquer absurdo político ou religioso que também mantenha os homens unidos" (Ideologia Alemã, p. 42-43).
\end{abstract}

Toda essa exposição conduz, por fim, ao quinto aspecto da história: a consciência. Segundo Marx, a consciência é de fato uma condição fundamental de toda a história humana. Porém, como vimos, não se trata de modo nenhum da consciência autônoma dos filósofos neo-hegelianos, da autoconsciência, nem do Espírito Absoluto de Hegel. Ao contrário, como diz Marx, o homem tem também consciência, ou seja, trata-se da constatação de um predicado do ser social que existe em meio a outros, e que, além disso, nasce da necessidade de intercâmbio entre os homens e, por conseguinte, é condicionado pela vida material dos homens. Como vimos, não é a consciência que distingue os homens dos animais, mas a atividade de produção dos seus meios de vida, atividade que por sua vez é consciente.

\footnotetext{
"Somente agora, depois de ter examinado quatro momentos, quatro aspectos das relações históricas originárias, verificamos que o homem tem também 'consciência'. Mas, ainda assim, não se trata de consciência 'pura'. Desde o início pesa sobre 'o espírito' a maldição de estar 'contaminado' pela matéria, que se apresenta sob a forma de camadas de ar em movimento, de sons, sem suma, de linguagem. A linguagem é tão antiga quanto a consciência - a linguagem é a consciência real, prática, que existe para os outros homens e, portanto, existe também para mim mesmo; e a linguagem nasce, como a consciência, da necessidade de intercâmbio com outros homens. [...] A consciência é, portanto, desde o início um produto social, e continuará sendo enquanto existirem homens" (Ideologia Alemã, p. 43).
} 
Até aqui, Marx expôs cinco momentos, cinco aspectos, cinco condições fundamentais de toda história, ou seja, condições que são tão antigas quanto o próprio homem e que estarão presentes enquanto existirem homens. São, portanto, aspectos inerentes à vida humana, comuns a todos os modos de produção e organizações sociais. O homem é o ser que produz a sua própria vida, pela sua própria atividade, e isso só é possível em conexão com outros homens e de maneira consciente.

Assim, tanto os meios de vida imediatos e as novas necessidades, quanto as relações sociais e as formas de consciência, ou seja, todas as manifestações da vida dos indivíduos, são apresentadas por Marx como produtos da atividade humana. Por isso, quando Marx se refere à produção da vida humana, é preciso esclarecer que se trata de um processo total, que envolve todas as manifestações da vida dos indivíduos, desde a sua base real, a produção material, até suas formações mais amplas. Diz Marx:

\footnotetext{
"Não se deve considerar tal modo de produção de um único ponto de vista, a saber: a reprodução da existência física dos indivíduos. Trata-se, muito mais, de uma determinada forma de atividade dos indivíduos, determinada forma de manifestar sua vida, determinado modo de vida dos mesmos. Tal como os indivíduos manifestam sua vida, assim são eles. $O$ que eles são coincide, portanto, com sua produção, tanto com o que produzem, como com o modo como produzem. $\mathrm{O}$ que os indivíduos são, portanto, depende das condições materiais de sua produção" (Ideologia Alemã, p. 27-28).
}

Aqui, Marx chama a atenção para o fato de que a produção da vida humana é a produção da existência humana em todos os seus aspectos, e não apenas do ponto de vista material, ou seja, da existência física dos indivíduos. A vida humana é apresentada por Marx como uma totalidade, e todos os seus aspectos (produção material, relações sociais, formas de consciência etc.) são igualmente produzidos pela própria atividade humana. Marx identifica o ser dos homens ao seu modo de atividade total, ao seu modo de vida. A história humana, portanto, é o processo total de produção da vida humana pelos próprios homens, o processo de autoprodução do homem.

Porém, em nenhum momento Marx abandona a determinação fundamental apresentada inicialmente e reiterada repetidamente ao longo do texto: o homem é o produtor de sua vida em todos os seus aspectos, mas sempre sobre a base real da produção material. Por isso, ao mesmo tempo em que todos os aspectos estão intimamente vinculados entre si, inclusive agindo reflexivamente uns sobre os outros, todos estão 
fundamentalmente condicionados pela produção da vida material. A produção da vida material é a base real da qual depende todo o modo de vida dos homens. "O que os indivíduos são, portanto, depende das condições materiais de sua produção" (Ideologia Alemã, p. 28). ${ }^{11}$

\title{
1.2. A divisão do trabalho como o fundamento real da ideologia
}

Toda a exposição de Marx até aqui, dado que seu alvo imediato são os filósofos neohegelianos, tem como objetivo principal a exposição do enraizamento real da consciência, ou seja, a apresentação da consciência como um produto social e, neste sentido, a determinação social da consciência. Como explicar, então, que os homens coloquem, na teoria, as suas relações reais de ponta cabeça? Como explicar as representações ideológicas do mundo? Através do processo de vida real dos homens. Como vimos, essas "formações nebulosas do cérebro humano são sublimações necessárias de seu processo de vida material". Mas qual o elemento específico, no interior do processo de vida real, que possibilita e, além disso, torna inevitável a inversão no plano da consciência? A divisão do trabalho. Segundo Marx,

\begin{abstract}
"A divisão do trabalho torna-se realmente divisão apenas a partir do momento em que surge uma divisão entre o trabalho material e o espiritual. A partir deste momento, a consciência pode realmente imaginar ser algo diferente da consciência da práxis existente, representar realmente algo sem representar algo real; desde este instante, a consciência está em condições de emancipar-se do mundo e entregar-se à criação da teoria, da teologia, da filosofia, da moral etc., 'puras'. Mas ainda que esta teoria, esta teologia, esta filosofia e esta moral etc. entrem em contradição com as relações sociais existentes, isso só pode acontecer porque as relações sociais existentes se encontram em contradição com as forças de produção existentes" (Ideologia Alemã, p. 45).
\end{abstract}

Generalizando, Marx afirma:

\footnotetext{
11 Às vezes, pode soar estranha a ênfase de Marx nessa determinação fundamental da vida humana pela produção material, o que se deve ao fato de seu texto dirigir-se aos idealistas neo-hegelianos. Porém, ainda assim, não há mecanicismo; há, isto sim, a constatação de uma determinação real, objetiva. Em nenhum momento Marx afirma que o pensamento dos homens é determinado imediatamente pela produção material. Ao contrário, Marx reconhece sempre a ação recíproca entre os diferentes elementos da vida humana, sem nunca perder de vista a determinação primordial das condições materiais de produção.
} 


\begin{abstract}
"de toda esta porcaria conservamos apenas um resultado, a saber: esses três momentos - a força de produção, o estado social e a consciência podem e devem entrar em contradição entre si, porque, com a divisão do trabalho, fica dada a possibilidade, mais ainda, a realidade, de que a atividade espiritual e a material - a fruição e o trabalho, a produção e o consumo - caibam a indivíduos diferentes; e a possibilidade de não entrarem esses elementos em contradição reside unicamente no fato de que a divisão do trabalho seja novamente superada" (Ideologia Alemã, p. 45-46).
\end{abstract}

Marx identifica a divisão do trabalho ou, mais especificamente, a divisão entre trabalho material e trabalho intelectual, entre "a atividade e o pensamento, isto é, atividade sem pensamento e pensamento sem atividade" (Ideologia Alemã, p. 45, suprimido do manuscrito) como o fundamento real da ideologia, ou seja, como a inversão real que gera a inversão no plano ideal. A divisão do trabalho gera a contradição prática entre as forças produtivas e as relações sociais; essa contradição prática é o que gera a contradição entre a teoria e as relações reais. Se na teoria os filósofos representam o mundo como um produto da consciência tornada autônoma, isso só é possível porque as próprias forças sociais reais estão separadas dos indivíduos, aparecendo como uma força estranha e independente deles.

"O poder social, isto é, a força produtiva multiplicada que nasce da cooperação de vários indivíduos exigida pela divisão do trabalho, aparece a estes indivíduos, porque sua cooperação não é voluntária mas natural, não como seu próprio poder unificado, mas como uma força estranha situada fora deles, cuja origem e cujo destino ignoram, que não podem mais dominar e que, pelo contrário, percorre agora uma série particular de fases e de estágios de desenvolvimento, independente do querer e do agir dos homens e que, na verdade, dirige este querer e agir" (Ideologia Alemã, p. 49-50).

Tanto a divisão do trabalho como a separação das forças sociais em relação aos indivíduos são condicionadas pelo baixo desenvolvimento das forças produtivas. Segundo Marx, o grau de emancipação possível em cada período histórico é determinado pelo nível de desenvolvimento das forças produtivas. Um desenvolvimento limitado das forças produtivas, pelo fato de não ser capaz de satisfazer toda a sociedade, gera necessariamente uma situação de antagonismo em que uns (uma minoria) se apropriam das forças produtivas 
enquanto outros (a maioria) são excluídos dessa apropriação e têm de lutar pelo necessário. Cada grau de emancipação conquistado ao longo da história foi fruto da criação de novas forças produtivas, que permitiram e impulsionaram o revolucionamento do modo anterior de satisfação das necessidades, isto é, da organização social anterior. Porém, até hoje, segundo Marx, toda emancipação conquistada foi limitada justamente porque foi realizada na base de forças produtivas insuficientes:

\begin{abstract}
"os homens atingiram de cada vez um grau de emancipação que lhes era prescrito e permitido, não pelo seu ideal de homem, mas pelas forças produtivas existentes. No entanto, todas as emancipações se realizaram até hoje na base de forças produtivas limitadas, cuja produção, incapaz de satisfazer toda a sociedade, só permitia o progresso se uns satisfizessem as suas necessidades a expensas dos outros, o que dava a uns - a minoria - o monopólio do progresso, enquanto os outros - a maioria - devido à sua luta contínua pela satisfação das necessidades mais elementares eram, entretanto (ou seja, até à criação de novas forças produtivas de caráter revolucionário), excluídos de todo o progresso. Assim, a sociedade evoluiu sempre no quadro de um antagonismo, o dos homens livres e dos escravos na antiguidade, dos nobres e dos servos na idade média, da bourgeoisie e do proletariado nos tempos modernos" (Ideologia Alemã, v. II, p. 291).
\end{abstract}

Isso significa que a divisão do trabalho e a propriedade privada, e de par com elas a ideologia, são produtos necessários do desenvolvimento limitado das forças produtivas. Segundo Marx, a ideologia não pode ser compreendida simplesmente como um erro da subjetividade individual. Ao contrário, a ideologia é uma "sublimação necessária" de relações reais baseadas na divisão do trabalho, ou seja, é um modo de afirmação necessário dos indivíduos que produzem a sua vida com base na divisão do trabalho, que por sua vez é determinada por forças produtivas limitadas. Sendo assim, a única maneira de superar a ideologia é superando a contradição que está na sua base, ou seja, superando a própria divisão do trabalho, o que por sua vez pressupõe um alto desenvolvimento das forças produtivas. $^{12}$

Segundo Marx, a divisão do trabalho é um sinônimo de propriedade privada, pois o que uma diz sobre a atividade, a outra diz sobre o produto da atividade. Uma determinada forma de organização da atividade produtiva implica necessariamente uma determinada forma de apropriação dos produtos dessa atividade. Assim, se a apropriação é desigual, isso

\footnotetext{
${ }^{12}$ Este tema será retomado com maior detalhe no Capítulo 5, sobre a emancipação humana.
} 
não se deve apenas à distribuição dos produtos: a desigualdade está presente já na própria distribuição da atividade produtiva, isto é, do trabalho, entre os indivíduos. Essa desigualdade, como vimos, tem como fundamento a divisão entre trabalho material e trabalho intelectual e, em última instância, o baixo nível de desenvolvimento das forças produtivas. Assim, a divisão do trabalho e a propriedade privada surgem como duas faces da mesma moeda. Nas palavras de Marx:

\begin{abstract}
"Com a divisão do trabalho, na qual todas estas contradições estão dadas e que repousa, por sua vez, na divisão natural do trabalho na família e na separação da sociedade em diversas famílias opostas umas às outras, dá-se ao mesmo tempo a distribuição, e com efeito a distribuição desigual, tanto quantitativa como qualitativamente, do trabalho e de seus produtos; ou seja, a propriedade, que já tem seu núcleo, sua primeira forma, na família, onde a mulher e os filhos são escravos do marido. [...] Além disso, divisão do trabalho e propriedade privada são expressões idênticas: a primeira enuncia em relação à atividade, aquilo que se enuncia na segundo em relação ao produto da atividade" (Ideologia Alemã, p. 46).
\end{abstract}

A transformação das forças produtivas gera uma transformação da divisão do trabalho que, por sua vez, gera uma transformação na propriedade. Para Marx, portanto, propriedade designa as relações dos indivíduos entre si, no que se refere ao material, ao instrumento e ao produto do trabalho. Nas suas palavras:

"cada nova força produtiva tem como consequência um novo desenvolvimento da divisão do trabalho [...] As diversas fases de desenvolvimento da divisão do trabalho representam outras tantas formas diferentes da propriedade: ou, em outras palavras, cada nova fase da divisão do trabalho determina igualmente as relações dos indivíduos entre si, no que se refere ao material, ao instrumento e ao produto do trabalho" (Ideologia Alemã, p. 29).

Apesar de serem de fato elementos necessários enquanto as forças produtivas não atingem um alto grau de desenvolvimento e de, por esse motivo, estarem presentes desde os primórdios da história humana, a divisão do trabalho e a propriedade privada não são para Marx elementos inerentes à vida social. Assim como a ideologia, portanto, são debilidades que podem e devem ser superadas no decorrer do desenvolvimento histórico dos homens, o que pressupõe forças produtivas altamente desenvolvidas. 
Até aqui, o foco da apresentação de Marx foi a consciência. Vimos que a consciência é uma condição fundamental de toda a história, mas que ela não possui existência autônoma; ao contrário, sendo um produto social, só pode ser compreendida a partir das relações reais entre os indivíduos. Indo mais além, Marx explica que a ideologia, essa forma de consciência de invertida do mundo, não é produto de um simples erro da subjetividade individual, mas, ao contrário, é fruto de uma inversão real, de uma debilidade social, mais especificamente, da divisão do trabalho, que tem como base a divisão entre trabalho material e trabalho intelectual. Mas de que nos serve tudo isso? O que tudo isso tem a ver com o nosso tema? Ocorre justamente que, para Marx,

\begin{abstract}
"A expressão idealista dos limites econômicos existentes não é apenas puramente teórica, mas existe também na consciência prática, isto é, a consciência que se emancipa e está em contradição com o modo de produção existente não constitui somente religiões e filosofias, mas também Estados" (Ideologia Alemã, p. 46, suprimido do manuscrito).
\end{abstract}

O paralelo entre a crítica do idealismo e a crítica da política está presente na obra de Marx desde a Crítica de 1843. Na Questão Judaica e na Introdução de 1843, Marx compara frequentemente a religião e o Estado moderno, apresentando ambos como diferentes formas de autoalienação humana, uma teórica e outra prática. Na Ideologia Alemã, Marx retoma e desenvolve essa comparação, concretizando as suas determinações e demonstrando que não se trata de uma simples analogia retórica, mas que, ao contrário, trata-se de um paralelo dado pela própria realidade - o que já está evidente na passagem citada acima. A crítica de Marx à política é, por um lado, uma ramificação de sua crítica da ideologia, isto é, crítica da ideologia política ${ }^{13}$, e, por outro lado, é a crítica da política enquanto tal, crítica do Estado e das relações políticas reais.

\footnotetext{
${ }^{13}$ Se bem que a própria crítica da ideologia política, como veremos no Capítulo 4, compreende não apenas a crítica dos filósofos e teóricos do direito e da política, como também a crítica do direito enquanto tal e da própria atuação política prática, seja dos estadistas, dos revolucionários franceses ou das insurreições operárias.
} 


\section{Crítica da política}

\subsection{A sociedade civil como base real do Estado}

Como vimos, a base de toda existência humana é a produção da vida material. A produção material condiciona (ainda que não de maneira mecânica, é claro) todos os aspectos da vida humana. Um modo determinado de produção material gera determinadas relações sociais e políticas, bem como determinadas formas de consciência. Sendo assim, Marx parte do reconhecimento de que o Estado e a política não possuem bases próprias, não têm existência autônoma, mas, ao contrário, são fruto de um determinado modo de vida dos indivíduos, cuja base é um determinado modo de produção material.

\footnotetext{
"O fato, portanto, é o seguinte: indivíduos determinados, que como produtores atuam de um modo também determinado, estabelecem entre si relações sociais e políticas determinadas. É preciso que, em cada caso particular, a observação empírica coloque necessariamente em relevo empiricamente e sem qualquer especulação ou mistificação - a conexão entre a estrutura social e política e a produção. A estrutura social e o Estado nascem constantemente do processo de vida de indivíduos determinados, mas destes indivíduos não como podem aparecer na imaginação própria ou alheia, mas tal e como realmente são, isto é, tal e como atuam e produzem materialmente e, portanto, tal e como desenvolvem suas atividades sob determinados limites, pressupostos e condições materiais, independentes de sua vontade" (Ideologia Alemã, p. 35).
}

Vimos acima que a conexão social é uma das condições fundamentais da existência humana e, enquanto tal, "é tão antiga quanto os homens". Essa conexão, segundo Marx, é dada pelo processo real de vida dos indivíduos, pelas necessidades e pela maneira de as satisfazer, ou seja, pelo modo de produção da vida material. No capítulo contra Stirner, Marx afirma:

"Os indivíduos 'partiram', sempre e em quaisquer circunstâncias, 'deles próprios', mas eles não eram únicos no sentido de que não poderiam deixar de ter relações entre si; pelo contrário, suas necessidades, portanto a sua natureza, e a maneira de as satisfazer, tornava-os dependentes uns dos outros (relações entre os sexos, trocas, divisão do trabalho); era portanto inevitável que se estabelecessem relações entre eles" (Ideologia Alemã, v. II, p. 300). 
Já na Sagrada Família Marx satirizava a "superstição política" (no caso, Bauer) por imaginar que o Estado seria o responsável pela coesão dos indivíduos, o que parte da suposição igualmente supersticiosa de que o indivíduo é naturalmente isolado. ${ }^{14}$ Aqui, Marx retoma essa crítica, demonstrando que a conexão social, tão antiga quanto os próprios homens, é determinada pelas necessidades e pela produção material, e não, como pretende a superstição política, pela vontade individual e pelo Estado, ou por "qualquer absurdo político ou religioso". Vale retomar as palavras do próprio Marx:

\begin{abstract}
"Desde o início mostra-se, portanto, uma conexão materialista dos homens entre si, condicionada pelas necessidades e pelo modo de produção, conexão esta que é tão antiga quanto os próprios homens - e que toma, incessantemente, novas formas e apresenta, portanto, uma 'história', sem que exista qualquer absurdo político ou religioso que também mantenha os homens unidos" (Ideologia Alemã, p. 42-43).
\end{abstract}

Ao determinar que a coesão social entre os homens é devida à sua própria natureza, isto é, às suas necessidades e ao modo de produção material; que, por esse motivo, era inevitável que os indivíduos estabelecessem relações entre si; e que, portanto, a conexão social é tão antiga quanto os próprios homens, Marx dissolve a identidade secular entre política e sociedade, demonstrando que a política não é intrínseca à vida social, ou seja, não é parte integrante da vida social como uma categoria eterna, mas apenas como um atributo historicamente circunstancial.

Ao mesmo tempo, Marx aprofunda o ponto de partida fundamental de toda sua crítica à política, isto é, a determinação conquistada já na Crítica de 1843 segundo a qual o Estado não é o produtor, mas sim o produto da sociedade civil. Agora, a sociedade civil é definida concretamente por Marx como a "organização social que se desenvolve imediatamente a partir da produção e do intercâmbio"; ela compreende, portanto, "toda a vida comercial e industrial de dada fase". Segundo Marx, é a sociedade civil assim definida ${ }^{15}$ que constitui a base real do Estado e do "resto da superestrutura idealista" - o que, diga-se

\footnotetext{
${ }^{14}$ A crítica da superstição política será desdobrada com maior detalhe no Capítulo 4.

${ }^{15}$ Como fica claro na citação a seguir, Marx utiliza o termo sociedade civil em dois sentidos: um geral, que abrange a organização social de qualquer época, e outro específico, que se refere apenas à sociedade burguesa. Este segundo sentido será desenvolvido no próximo capítulo. Por ora, interessa-nos apenas o primeiro sentido, geral.
} 
de passagem, inclui o Estado na "superestrutura idealista". Acompanhemos a definição geral de sociedade civil nas palavras de Marx:

\begin{abstract}
"A forma de intercâmbio, condicionada pelas forças de produção existentes em todas as fases históricas anteriores e que, por sua vez, as condiciona, é a sociedade civil; [...] A sociedade civil abrange todo o intercâmbio material dos indivíduos, no interior de uma fase determinada de desenvolvimento das forças produtivas. Abrange toda a vida comercial e industrial de uma dada fase e, neste sentido, ultrapassa o Estado e a nação, se bem que, por outro lado, deve se fazer valer frente ao exterior como nacionalidade e organizar-se no interior como Estado. A expressão 'sociedade civil' aparece no século XVIII, quando as relações de propriedade já se tinham desprendido da comunidade antiga e medieval. A sociedade civil, como tal, desenvolve-se apenas com a burguesia; entretanto, a organização social que se desenvolve imediatamente a partir da produção e do intercâmbio e que forma em todas as épocas a base do Estado e do resto da superestrutura idealista, foi sempre designada, invariavelmente, com o mesmo nome" (Ideologia Alemã, p. 52-53).
\end{abstract}

Isso significa que o Estado - assim como todo o resto da "superestrutura idealista" não é um ente autônomo, mas, ao contrário, se ergue sobre a base real da sociedade civil. Só a "superstição política" poderia ser capaz de inverter as coisas ao ponto de se limitar às ações políticas isoladas de sua base efetiva:

\footnotetext{
"Vê-se, já aqui, que esta sociedade civil é a verdadeira fonte, o verdadeiro cenário de toda a história, e quão absurda é a concepção histórica anterior que, negligenciando as relações reais, limitava-se às ações altissonantes dos príncipes e dos Estados" (Ideologia Alemã, p. 53).
}

A identificação da sociedade civil, no sentido geral de "organização social que se desenvolve imediatamente a partir da produção e do intercâmbio", como o verdadeiro cenário de toda história é ao mesmo tempo uma determinação fundamental da concepção de Marx sobre a vida humana em geral e o ponto de partida de sua crítica à política.

A história é o processo de produção da vida humana pela própria atividade dos homens. Compreender a história, para Marx, significa compreender esse processo real em sua totalidade. Mas, no interior dessa totalidade, há diferentes elementos, que ocupam diferentes posições. O pressuposto primeiro de todo esse processo, como vimos, é a produção material da vida imediata; essa produção gera uma determinada forma de intercâmbio, a sociedade civil - ela é o fundamento de toda a história. Daqui deve partir 
toda a compreensão das outras formas de atividade humana, sejam práticas ou teóricas. A base é a produção da vida material e a forma de intercâmbio associada a ela; sobre essa base, ergue-se a "superestrutura idealista", que inclui o Estado e os diversos produtos da consciência.

Marx sintetiza a relação entre os vários aspectos da vida humana, indicando suas determinações principais no interior da totalidade que formam, sem nunca perder de vista que há relações recíprocas e que, portanto, não se trata de mecanicismo:

\begin{abstract}
"Esta concepção da história consiste, pois, em expor o processo real de produção, partindo da produção material da vida imediata; e em conceber a forma de intercâmbio conectada a este modo de produção e por ele engendrada (ou seja, a sociedade civil em suas diferentes fases) como o fundamento de toda a história, apresentando-a em sua ação enquanto Estado e explicando a partir dela o conjunto dos diversos produtos teóricos e formas da consciência - religião, filosofia, moral etc. - assim como em seguir seu processo de nascimento a partir desses produtos; o que permite então, naturalmente, expor a coisa em sua totalidade (e também, por isso mesmo, examinar a ação recíproca entre estes diferentes aspectos)." (Ideologia Alemã, p. 55).
\end{abstract}

O Estado, que aqui é o nosso foco, deve ser explicado a partir de sua base real, isto é, da sociedade civil. Como se evidencia nesta passagem, explicar o Estado é na verdade apresentar a sociedade civil em sua ação enquanto Estado, o que revela que, para Marx, o Estado não passa de uma forma de atuação da sociedade civil. O Estado não é um conjunto de relações autônomas e determinantes da estrutura social; ao contrário, é um produto da sociedade civil e de sua ação. Em outras palavras, as relações políticas são formas assumidas pelas relações sociais num determinado momento histórico.

Em outra passagem, Marx reafirma da mesma maneira a articulação entre os diferentes aspectos da vida social - a base formada pela produção material e pela estrutura social, o Estado e as formas de consciência. Segundo ele, trata-se de

\footnotetext{
"explicar a partir das condições empíricas e de mostrar como certas relações industriais e de trocas $^{16}$ estão necessariamente ligadas a uma forma de sociedade determinada, portanto a uma certa forma de Estado e, consequentemente, a uma forma determinada da consciência religiosa [idealista, ideológica, invertida]" (Ideologia Alemã, v. I, p. 183).
}

\footnotetext{
${ }^{16}$ Troca tem aqui o sentido amplo de intercâmbio.
} 
Na Carta a Annenkov, Marx reafirma essa articulação geral de maneira ainda mais concreta e define o regime político como a expressão oficial da sociedade civil:

\begin{abstract}
"A um determinado nível de desenvolvimento das forças produtivas dos homens, corresponde determinada forma de comércio $^{17}$ e de consumo. A determinadas fases de desenvolvimento da produção, do comércio e do consumo, correspondem determinadas formas de constituição social, determinada organização da família, dos estamentos ou das classes; em uma palavra, uma determinada sociedade civil. A uma determinada sociedade civil, corresponde um determinado regime político, que não é mais do que a expressão oficial da sociedade civil." (Carta a Annenkov, p. 172).
\end{abstract}

E, logo adiante, referindo-se às revoluções inglesas de 1640 e 1688:

"Na Inglaterra, foram destruídas todas as velhas formas econômicas, as relações sociais com ela congruentes e o regime político que era expressão oficial da velha sociedade civil" (Carta a Annenkov, p. 172).

Vimos que o Estado e a política, assim como a consciência, são para Marx atributos do ser social, que portanto não podem ser compreendidos como seres autônomos, com história e desenvolvimento próprios. Nesse sentido, é preciso partir de seu enraizamento social real, de sua determinação pelas forças de produção e pela forma de intercâmbio de uma dada fase social. Porém, como vimos e como será enfatizado ao longo de toda esta tese, enquanto a consciência é uma condição fundamental de toda história, o Estado e a política são predicados extrínsecos à vida social. E, assim como a forma de consciência idealista, filosófica ou religiosa, também são necessários apenas sob o domínio da divisão do trabalho e da propriedade privada, ou seja, em formações sociais ainda limitadas, identificadas por Marx como a "pré-história da humanidade". A política em geral é identificada por Marx, desde já, como uma limitação, como uma debilidade, ou, mais precisamente, como fruto de formações sociais limitadas, ainda incapazes de autorregulação puramente social, justamente por estarem fundadas na divisão do trabalho.

\footnotetext{
${ }^{17}$ Aqui é o próprio Marx quem esclarece: "Faço uso aqui da palavra comércio em seu sentido mais amplo, do mesmo modo que empregamos em alemão o vocábulo Verkehr" (Carta a Annenkov, p. 171)
} 


\title{
2.2. O Estado como produto da divisão do trabalho
}

"o Estado, em razão da divisão do trabalho, constitui um organismo próprio, separado da sociedade" (Crítica de Gotha, 240).

Segundo Marx, o Estado e a política são tão historicamente circunstanciais quanto a propriedade privada e a divisão do trabalho.

\begin{abstract}
"A vida material dos indivíduos, que não depende de modo nenhum apenas da sua 'vontade', o seu modo de produção e as suas modalidades de troca, que se condicionam reciprocamente, são a base real do Estado e continuarão a sê-lo em todos os estádios em que sejam ainda necessárias a divisão do trabalho e a propriedade privada" (Ideologia Alemã, v. II, p. 135136).
\end{abstract}

Ao invés de aparecer como a esfera mais elevada da atividade humana, a política aparece em Marx como uma limitação, que aliás é fruto indissociável de uma fraqueza social, identificada por Marx concretamente no baixo nível de desenvolvimento das forças produtivas, que torna necessárias a divisão do trabalho e a propriedade privada. Segundo Marx, portanto, a política é um atributo necessário não à vida social em geral, mas apenas à vida social baseada na divisão do trabalho e na propriedade privada.

Como vimos, com a divisão do trabalho, o poder social aparece aos indivíduos não como seu próprio poder unificado, mas como uma força estranha, situada fora deles e eles oposta. O Estado, para Marx, é justamente uma das formas assumidas por essa força social alienada. Em outras palavras, o Estado é

"a esfera particular, à qual foi atribuída a administração dos interesses públicos em resultado da divisão do trabalho" (Ideologia Alemã, v. I, p. 242)

A divisão do trabalho leva à contradição entre interesse particular e interesse coletivo. Segundo Marx, esta contradição faz com que o interesse coletivo assuma uma forma autônoma na qualidade de Estado. Autônoma no sentido de que está separado dos reais interesses particulares e gerais, mas nunca no sentido de existir com bases próprias. Pois, como vimos e como será sempre reiterado por Marx, o Estado só existe sobre a base das relações sociais reais. 
"com a divisão do trabalho é dada ao mesmo tempo a contradição entre o interesse do indivíduo ou da família singulares e o interesse coletivo de todos os indivíduos que se relacionam entre si; e, com efeito, este interesse coletivo não existe apenas na representação, como 'interesse geral', mas se apresenta, antes de mais nada, na realidade, como a dependência recíproca de indivíduos entre os quais o trabalho está dividido. [...] É justamente desta contradição entre o interesse particular e o interesse coletivo que (1) o interesse coletivo toma, na qualidade de Estado, uma forma autônoma, separada dos reais interesses particulares e gerais e, ao mesmo tempo, na qualidade de uma coletividade ilusória, (2) mas sempre sobre a base real dos laços existentes em cada conglomerado familiar e tribal - tais como, laços de sangue, linguagem, divisão do trabalho em maior escala e outros interesses - e sobretudo, como desenvolveremos mais adiante, baseada nas classes, já condicionadas pela divisão do trabalho, que se isolam em cada um destes conglomerados humanos e entre as quais há uma que domina todas as outras" (Ideologia Alemã, p. 47).

O Estado é o interesse coletivo tornado autônomo, separado dos reais interesses gerais e particulares. Logo, o Estado surge como uma coletividade ilusória, uma comunidade aparente, separada dos próprios indivíduos, portanto uma comunidade abstrata. Essa ideia, que já aparecia na Questão Judaica principalmente em relação ao Estado moderno, aparece agora na Ideologia Alemã não apenas com um grau de concreção consideravelmente maior, como também estendida explicitamente a todas as formas de Estado, desde as primeiras, baseadas na propriedade tribal, até o próprio Estado moderno, baseado nas classes.

Vimos que, segundo Marx, o Estado é a expressão idealista prática dos limites econômicos existentes, assim como as religiões e as filosofias (idealistas) são sua expressão teórica. Em diversas passagens da Ideologia Alemã, Marx afirma que o Estado é o reflexo prático-idealista da sociedade civil. Isso na medida em que ele constitui a forma prática assumida pelo poder social separado dos próprios indivíduos. O Estado é, para Marx, uma alienação da força social, que se concentra num órgão à parte, separado da sociedade.

No entanto, uma vez que o Estado é fruto da cisão no interior da sociedade civil e da consequente autonomização do interesse coletivo, o poder político em geral se revela necessariamente como poder de uma parcela da sociedade sobre as demais. Isso significa que enquanto houver Estado e política haverá necessariamente dominação e servidão. $\mathrm{O}$ ilusório interesse geral se revela assim como o interesse de manutenção da ordem de coisas existente e, portanto, como o interesse de manutenção de determinadas relações de dominação. 
Na Ideologia Alemã, Marx é taxativo:

"As condições sob as quais determinadas forças produtivas podem ser utilizadas são as condições de dominação de determinada classe ${ }^{18}$ da sociedade, cujo poder social, decorrente de sua riqueza, encontra sua expressão prático-idealista na forma do Estado imperante em cada caso" (Ideologia Alemã, p. 108).

Esse poder pode se impor como um interesse geral estranho aos indivíduos, ou permitir que apareça o conflito entre esse interesse ilusoriamente coletivo e os interesses particulares, como ocorre na democracia. Porém, independentemente da forma que assuma, a oposição real, prática entre os interesses torna sempre necessária a intervenção igualmente prática do Estado nos momentos em que o interesse (ilusoriamente) coletivo é ameaçado:

\begin{abstract}
"Justamente porque os indivíduos procuram apenas seu interesse particular, que para eles não coincide com seu interesse coletivo (o geral é de fato a forma ilusória da coletividade), este interesse comum faz-se valer como um interesse 'estranho' aos indivíduos, 'independente' deles, como um interesse 'geral' especial e peculiar; ou têm necessariamente de enfrentar-se com este conflito, tal como na democracia. Por outro lado, a luta prática destes interesses particulares, que constantemente e de modo real chocam-se com os interesses coletivos e ilusoriamente tidos como coletivos, torna necessário o controle e a intervenção prática através do ilusório interesse-'geral' como Estado"' (Ideologia Alemã, p. 49).
\end{abstract}

Assim, em todas as épocas, o Estado surge necessariamente como o poder de manutenção da ordem, ou seja, de determinada forma social existente; ou, mais precisamente, de determinada forma de dominação da classe apropriadora sobre a classe produtora. Nas palavras de Marx, independentemente de sua forma,

"Ele fora sempre o poder para a manutenção da ordem, isto é, da ordem existente da sociedade e, portanto, da subordinação e exploração da classe produtora pela classe apropriadora" (A Guerra Civil na França, Segundo Rascunho, p. 170). ${ }^{19}$

\footnotetext{
${ }^{18}$ Aqui, o termo classe é usado no sentido amplo, valendo para qualquer forma social, não apenas para a sociedade burguesa.

${ }^{19}$ Embora nesse contexto Marx esteja se referindo especificamente à história do Estado moderno, é evidente que essa afirmação vale para qualquer forma de Estado.
} 
Como dizia Marx no Prefácio de 1859, com o qual iniciamos este capítulo, o segredo do Estado e das relações políticas e jurídicas em geral deve ser buscado na sociedade civil, que constitui sua base real; e o segredo da sociedade civil, por sua vez, deve ser buscado na economia política. Assim, é a análise da forma de produção da vida material de cada época que explica tanto a sua forma social quanto a sua consequente forma política.

A forma assumida pela relação direta entre os proprietários dos meios de produção e os produtores imediatos, sempre condicionada por um determinado nível de desenvolvimento das forças produtivas, é para Marx o verdadeiro segredo, o fundamento escondido de todo o edifício social e de sua correspondente forma política. A forma específica que reveste o Estado em cada caso surge agora, precisamente, como a forma política assumida pela relação de soberania e dependência, que tem como fundamento a forma econômica da relação entre os produtores e os apropriadores.

\begin{abstract}
"A forma econômica específica na qual o trabalho extra não remunerado é retirado dos produtores diretos determina a relação de dominação e servidão, uma vez que ela cresce diretamente da própria produção e reage por sua vez de modo determinante sobre ela. Nisso se baseia toda a configuração da comunidade econômica que surge das relações de produção presentes, e consequentemente também sua forma política específica. É em cada caso na relação direta entre os proprietários dos meios de produção e os produtores imediatos - relação cuja forma particular sempre corresponde naturalmente a um certo grau de desenvolvimento do tipo de trabalho, e portanto a um certo grau de força produtiva social - que se encontra o segredo mais profundo, o fundamento escondido de todo o edifício social, e por consequência da forma política que assume a relação de soberania e dependência, em suma, a base de toda a forma específica que reveste o Estado em cada caso. Isso não impede que a mesma base econômica - a mesma quanto às condições principais - possa, devido a inúmeras circunstâncias empíricas distintas, condições naturais, relações raciais, influências históricas externas etc., exibir infinitas variações e graduações em sua manifestação, que só podem ser entendidas mediante análise dessas circunstâncias empiricamente dadas." (O Capital, v. 3, p. 251-252). ${ }^{20}$
\end{abstract}

\footnotetext{
20 "The specific economic form, in which unpaid surplus-labour is pumped out of direct producers, determines the relationship of rulers and ruled, as it grows directly out of production itself and, in turn, reacts upon it as a determining element. Upon this, however, is founded the entire formation of the economic community which grows up out of the production relations themselves, thereby simultaneously its specific political form. It is always the direct relationship of the owners of the conditions of production to the direct producers - a relation always naturally corresponding to a definite stage in the development of the methods of labour and thereby its social productivity - which reveals the innermost secret, the hidden basis of the entire social structure and with it the political form of the relation of sovereignty and dependence, in short, the
} 
Vimos que o Estado não é um ser autônomo, mas se enraíza nas relações sociais reais, mais especificamente, nas relações materiais de vida. O Estado surge então como produto da sociedade civil ou, mais precisamente, como produto necessário da divisão do trabalho. Agora, o Estado aparece como o poder para a manutenção da ordem ou, mais precisamente, como a forma política assumida pela dominação dos produtores pelos apropriadores. Isso significa que, para Marx, em todas as épocas e em todas as formas, o Estado implica necessariamente a relação de dominação e servidão, ou seja, a ausência de liberdade. Essa relação de dominação e servidão constitui a sua base real, o fundamento sobre o qual repousa e do qual é impossível destacá-lo, a não ser através da abstração, pois eles estão organicamente fundidos entre si.

Já nas Glosas de 1844 Marx comparava o Estado antigo com o Estado moderno demonstrando que ambos repousam sobre formas diferentes de escravidão e que, portanto, o Estado, não apenas o Estado moderno ou o Estado antigo, mas o Estado em geral é indissociável da escravidão - nesse sentido de ausência de liberdade. Diz Marx:

\begin{abstract}
"Com efeito, essa dilaceração, essa infâmia, esta escravidão da sociedade civil, constitui o fundamento natural em que se baseia o Estado moderno, assim como a sociedade civil da escravidão constituía o fundamento sobre o qual descansava o Estado antigo. A existência do Estado e a existência da escravidão são inseparáveis. O Estado antigo e a escravidão antiga - francos e sinceros antagonismos clássicos - não se encontravam fundidos entre si mais estreitamente do que o Estado moderno e o moderno mundo das trocas, hipócritas antagonismos cristãos" (Glosas de 1844, p. 513).
\end{abstract}

corresponding specific form of the state. This does not prevent the same economic basis - the same from the standpoint of its main conditions - due to innumerable different empirical circumstances, natural environment, racial relations, external historical influences, etc. from showing infinite variations and gradations in appearance, which can be ascertained only by analysis of the empirically given circumstances." (Capital, v. 3, versão online). 


\title{
II. CRÍTICA DO ESTADO MODERNO
}

\author{
"os diferentes Estados dos diferentes países \\ civilizados, apesar de suas variadas configurações, \\ têm em comum o fato de estarem assentados \\ sobre o solo da moderna sociedade burguesa, \\ mais ou menos desenvolvida em termos \\ capitalistas. É o que confere a eles certas \\ características comuns essenciais." (Crítica de \\ Gotha, p. 42).
}

Neste capítulo, serão desenvolvidos alguns dos principais aspectos da crítica de Marx ao Estado moderno. Em primeiro lugar, será evidenciado que, apesar da imensa variedade de suas formas, todos os Estados têm em comum o fato de assentarem sobre a base da moderna sociedade burguesa. O Estado moderno é então revelado como produto da propriedade privada moderna. Na medida em que esta se despoja completamente da comunidade, o Estado se constitui como comunidade abstrata, ao lado e fora da sociedade. A liberdade concedida pelo Estado, ao invés de ser a liberdade real do homem, surge antes como a liberdade dos elementos da sociedade burguesa em relação ao privilégio, ou seja, a liberdade para a moderna sociedade burguesa se desenvolver freneticamente, sem nenhum empecilho. O Estado moderno, portanto, não apenas é fruto da escravidão da propriedade privada e descansa sobre ela, como é dela indissociável.

Em segundo lugar, o Estado moderno será revelado como cão de guarda da propriedade privada e, consequentemente, como instrumento de dominação de classe. Embora sua forma possa ser mais ou menos desenvolvida, o conteúdo do Estado é sempre a garantia da propriedade privada, ou seja, das condições materiais de dominação da burguesia. Isso significa que o Estado, em sua forma pura, ou seja, em sua essência, tem como objetivo eternizar a dominação do capital e a escravidão do trabalho. As formas de Estado mais desenvolvidas são as que mais trazem ameaças à dominação da burguesia. Portanto, nos momentos em que os trabalhadores questionam revolucionariamente os fundamentos da sociedade burguesa, o Estado não só manifesta nitidamente sua verdadeira natureza, como tende a se contrair ou regredir para formas menos desenvolvidas, e por isso mais seguras do ponto de vista da burguesia. Aqui fica evidente que a finalidade do Estado é manutenção da sociedade burguesa, portanto, da dominação econômica da burguesia, que 
não necessariamente precisa coexistir com sua dominação política. Pelo contrário, às vezes é inclusive necessário que a própria burguesia seja excluída da cena política para garantir a "manutenção ordem", como no caso do Estado bonapartista, no Segundo Império.

Em terceiro lugar, a partir da análise do fato da emancipação política, ou seja, da forma mais desenvolvida do Estado moderno, o Estado representativo democrático, serão desvendados os seus limites intrínsecos no que se refere à sua (in)capacidade de realizar a liberdade humana. Aqui, a crítica de Marx demonstra que a liberdade do Estado não significa a liberdade real do homem e que não há como aperfeiçoar o Estado para corrigir seus defeitos; pelo contrário, os defeitos estão presentes em sua forma mais acabada, mais perfeita, e portanto são defeitos absolutos, que fazem parte da sua própria natureza. Desde já, o Estado, inclusive e especialmente na sua configuração mais perfeita e acabada - o Estado democrático - se apresenta como forma limitada, e intrinsecamente limitada, de realização da liberdade humana. Ao mesmo tempo, segundo Marx, o Estado democrático representa o nível máximo de liberdade que pode ser alcançado dentro da sociedade capitalista.

Isso tudo nos leva, por fim, à desmistificação do Estado como esfera de realização da liberdade humana. O Estado não é um instrumento neutro, corrompido pela burguesia, que poderia ser utilizado para outros fins. Também não é uma instituição eterna, dada, a partir da qual se realiza a organização da sociedade. Pelo contrário, o Estado é uma criação histórica, indissociavelmente vinculada à propriedade privada e, portanto, à dominação da burguesia enquanto classe. A constatação do vínculo indissociável entre o Estado e o capital, sendo o primeiro súdito do segundo, conduz à conclusão de que mesmo em sua forma mais desenvolvida, a democracia, o Estado é intrinsecamente limitado, sendo a democracia o nível máximo de liberdade dentro da sociedade capitalista. Assim, embora o aperfeiçoamento de Estados ainda não desenvolvidos não seja nada desprezível, o prosseguimento da construção da liberdade humana só pode se dar, segundo Marx, para além do Estado e da política em geral. 


\section{O vínculo orgânico entre o Estado e a propriedade privada}

"o Estado só existe por causa da propriedade privada" (Ideologia Alemã, p. 98)

Como vimos no primeiro capítulo, a base real do Estado e das relações políticas em geral é a sociedade civil no sentido amplo, ou seja, a organização social que se desenvolve imediatamente a partir da produção e do intercâmbio. Já a base do Estado moderno é identificada por Marx na sociedade civil no seu sentido mais estrito, ou seja, na sociedade civil como tal, a sociedade burguesa, que tem como base a propriedade privada moderna, completamente emancipada da comunidade.

\footnotetext{
“A expressão 'sociedade civil' aparece no século XVIII, quando as relações de propriedade já se tinham desprendido da comunidade antiga e medieval. A sociedade civil, como tal, desenvolve-se apenas com a burguesia" (Ideologia Alemã, p. 52-53).
}

A dissolução dos laços genéricos entre os indivíduos e a consequente instauração da sociedade civil é identificada por Marx como o processo de gênese do Estado moderno. E a causa da dissolução dos laços comunitários, por sua vez, é identificada no surgimento da moderna propriedade privada. Aqui, ficará evidente que o Estado só existe por causa da propriedade privada, que ele é dela indissociável e, mais ainda, que sua função primordial (na história e pela sua natureza) é garantir, não a liberdade do homem, mas sim a liberdade dessa propriedade privada e dos elementos da sociedade burguesa, portanto, dessa forma de escravidão humana.

Segundo Marx, a antiga sociedade civil, a sociedade feudal, possui um caráter diretamente político, ou seja, os elementos da vida civil determinavam a relação do indivíduo singular com o Estado como totalidade, de modo que o poder político geral só poderia se manifestar como assunto de poucos indivíduos. Assim, ao derrubar o poder do soberano e ao elevar os negócios do Estado a negócios do povo,

"A revolução política aboliu [...] o caráter político da sociedade civil. Dissolveu a sociedade civil nos seus elementos simples, de um lado, os indivíduos, do outro, os elementos materiais e culturais que formam o 
conteúdo vital, a situação civil destes indivíduos" (Questão Judaica, p. 6061)

Com isso, a revolução política

"Pôs em liberdade o espírito político [...] libertou-o da sua adulteração com a vida civil e constituiu-o como a esfera da comunidade, o interesse geral do povo, numa independência ideal dos elementos particulares da vida civil. A atividade e a situação vitais específicas mergulharam numa significação puramente individual. Deixaram de constituir a relação geral entre o indivíduo e o Estado como totalidade. $\mathrm{O}$ assunto público tornou-se, antes, assunto geral de cada indivíduo e a função política transformou-se na sua função geral" (Questão Judaica, p. 61).

A revolução política "libertou o espírito político de sua adulteração com a vida civil" e transformou o assunto político em assunto geral de cada indivíduo.

\footnotetext{
"Mas a consumação do idealismo do Estado era ao mesmo tempo a realização do materialismo da sociedade civil. Os laços que acorrentavam o espírito egoísta da sociedade civil foram removidos juntamente com o jugo político. A emancipação política foi simultaneamente uma emancipação da sociedade civil a respeito da política, e até da aparência de um conteúdo geral" (Questão Judaica, p. 61).
}

Aqui, Marx destaca um outro aspecto da revolução política. Se ela significou a remoção do jugo político feudal, é preciso notar que ela significa ao mesmo tempo a remoção dos laços que acorrentavam o espírito egoísta da sociedade civil. Segundo Marx, a revolução política fez com que os elementos particulares da vida civil não tivessem mais caráter político, ou seja, não determinassem mais a relação do indivíduo singular com o Estado como totalidade. Mas, como vimos, ela só consegue isso através da separação entre os indivíduos, de um lado, e seu conteúdo vital, de outro.

Sendo assim, a revolução política não liberta o indivíduo dos elementos alienados que formavam o conteúdo de sua vida civil (constrangimentos seculares), mas, ao contrário, apenas põe esses elementos em liberdade, ou seja, permite que se movimentem freneticamente. A liberdade alcançada, segundo Marx, é portanto a liberdade daquele homem, que constituía o fundamento da sociedade feudal, o homem egoísta, isto é, o homem separado dos outros homens e da comunidade. 
“Napoleão já possuía também o conhecimento da essência do Estado moderno, e compreendia que este tem como base o desenvolvimento desenfreado da sociedade burguesa, o livre jogo dos interesses privados etc." (Sagrada Familia, p. 142)

Na Sagrada Família, Marx retoma, embora não nos mesmos termos, o seu desenvolvimento da Questão Judaica sobre a consumação simultânea do idealismo de Estado e do materialismo da sociedade civil e sobre o fato de que o Estado tem pressupostos reais, os quais, embora expulsos da esfera política, continuam agindo à sua maneira na sociedade civil. Na Sagrada Família, Marx demonstra que a moderna sociedade civil só começa a se desenvolver em toda a sua extensão ao se libertar do privilégio, ou seja, quando os elementos da sociedade civil deixam de ter caráter político e são abandonados a si mesmos:

"O Estado declara que a religião, assim como os demais elementos burgueses da vida, apenas começaram a existir em toda a sua extensão no mesmo instante em que os esclarece como apolíticos, deixando-os largados a si mesmos, portanto. À dissolução de sua existência política, como por exemplo à dissolução da propriedade mediante a abolição do censo eleitoral, ou à supressão da religião mediante a dissolução da Igreja estatal, a essa proclamação de sua morte civil dentro do Estado, corresponde sua vida mais poderosa, que agora obedece a suas próprias leis sem que ninguém a estorve, e pode estender sua própria existência em toda a sua extensão" (Sagrada Família, p. 136).

Mais adiante, Marx reafirma essa determinação, demonstrando que a indústria, a propriedade e o comércio, assim como a religião, só começam a se realizar verdadeiramente a partir do momento em que se encontram livres do privilégio, ou seja, abandonados a si mesmos:

"Porém, assim como a atividade industrial não é superada imediatamente depois de serem superados os privilégios das indústrias, das agremiações e corporações, mas, ao contrário, só depois da superação desses privilégios é que começa a indústria real; assim como a propriedade da terra não é superada, mas, ao contrário, seu movimento universal começa de fato com a superação de seus privilégios, através do livre parcelamento e da livre alienação; assim como o comércio não é superado com a superação dos privilégios comerciais, mas, ao contrário, passa a se realizar verdadeiramente no livre comércio; assim também a religião apenas se desdobra em sua universalidade prática (basta pensar nos Estado livres da 
América do Norte) justamente ali onde não existe uma religião privilegiada" (Sagrada Família, p. 134).

Com isso, a sociedade civil surge como o conjunto de indivíduos não mais vinculados aos outros nem sequer através da aparência de um nexo geral (o homem egoísta da Questão Judaica), ou seja, como a luta de todos contra todos:

\begin{abstract}
"Assim como a livre indústria e o livre comércio superam a determinação privilegiada e, com ela, superam a luta das determinações privilegiadas entre si, substituindo-as pelo homem isento de privilégios - do privilégio que isola da coletividade geral, tendendo ao mesmo tempo a constituir uma coletividade exclusiva mais reduzida -, não vinculado aos outros homens nem sequer através da aparência de um nexo geral e criando a luta geral do homem contra o homem, do indivíduo contra o indivíduo, assim a sociedade burguesa em sua totalidade é essa guerra de todos os indivíduos, uns contra os outros, já apenas delimitados entre si por sua individualidade, e o movimento geral desenfreado das potências elementares da vida, livres das travas dos privilégios" (Sagrada Família, p. 135).
\end{abstract}

Com isso, assim como na Questão Judaica, Marx demonstra a indissociabilidade e o condicionamento mútuo entre o Estado moderno acabado e a sociedade civil desenvolvida, apresentando a segunda como base do primeiro e o primeiro como garantia da segunda:

"A anarquia é a lei da sociedade burguesa emancipada dos privilégios que distinguem, e a anarquia da sociedade burguesa é a base do estado de coisas público moderno, assim como o estado de coisas público é, por sua vez, o que garante essa anarquia. Na mesma medida em que ambos se contrapõem, ambos se condicionam mutuamente" (Sagrada Família, p. 136).

Nas Glosas Críticas, como vimos no primeiro capítulo, Marx compara a relação entre o Estado antigo e a escravidão antiga com a relação entre o Estado moderno e a escravidão da sociedade civil (o moderno mundo das trocas), denunciando a indissociabilidade entre Estado e escravidão. Vale retomar a passagem:

"Com efeito, esta dilaceração, esta vileza, esta escravidão da sociedade civil, constitui o fundamento natural em que se baseia o Estado moderno, assim como a sociedade civil da escravidão constituía o fundamento sobre o qual descansava o Estado antigo. A existência do Estado e a existência da escravidão são inseparáveis. O Estado antigo e a escravidão antiga - francos e sinceros antagonismos clássicos - não se encontravam fundidos entre si 
mais estreitamente do que o Estado moderno e o moderno mundo das trocas, hipócritas antagonismos cristãos" (Glosas Críticas, p. 513).

Na Sagrada Família, Marx retoma esse desenvolvimento, articulando-o com as posições da Questão Judaica:

\begin{abstract}
"Demonstrou-se como o reconhecimento dos direitos humanos por parte do Estado moderno tem o mesmo sentido que o reconhecimento da escravatura pelo Estado antigo. Com efeito, assim como o Estado antigo tinha como fundamento natural a escravidão, o Estado moderno tem como base natural a sociedade burguesa e o homem da sociedade burguesa, quer dizer, o homem independente, entrelaçado com o homem apenas pelo vínculo do interesse privado e da necessidade natural inconsciente, o escravo do trabalho lucrativo e da necessidade egoísta, tanto da própria quanto da alheia" (Sagrada Família, p.132).
\end{abstract}

E, mais adiante:

\begin{abstract}
"A antítese entre o Estado representativo democrático e a sociedade burguesa é a culminação da antítese clássica entre a comunidade pública e a escravidão. No mundo moderno, todos são, a um só tempo, membros da escravidão e da comunidade. Precisamente a escravidão da sociedade burguesa é, em aparência, a maior liberdade, por ser a independência aparentemente perfeita do indivíduo, que toma o movimento desenfreado dos elementos estranhados de sua vida, já não mais vinculados pelos nexos gerais nem pelo homem, por exemplo, o movimento da propriedade, da indústria, da religião etc., por sua própria liberdade, quando na verdade é, muito antes, sua servidão e sua falta de humanidade completas e acabadas. O privilégio é substituído aqui pelo direito" (Sagrada Família, p. 135).
\end{abstract}

Aqui, a oposição entre o Estado democrático e a sociedade civil surge como a culminação da antítese clássica entre a comunidade pública e a escravidão. A sociedade civil moderna é denunciada como forma de escravidão, mas apenas no sentido de ausência de liberdade. Porém, continua Marx, trata-se de uma escravidão que aparenta ser a maior liberdade, na medida em que o indivíduo considera o movimento desenfreado dos elementos estranhados da sua vida civil como se fosse a sua própria liberdade. Essa liberdade aparente surge para Marx como a servidão e a falta de humanidade completas e acabadas do indivíduo. Assim, a liberdade alcançada com a emancipação política é a liberdade dos elementos estranhados da vida civil em relação ao privilégio, e não a liberdade real do homem. 
$\mathrm{Na}$ Ideologia Alemã, Marx reafirma essa determinação fundamental da Questão Judaica e da Sagrada Família, isto é, o fato de o Estado moderno ter como base a propriedade privada moderna. Marx reitera que a propriedade privada moderna é aquela que se emancipou completamente da comunidade e até da aparência de comunidade, instaurando a luta de todos contra todos, e que por isso a comunidade só pode existir como uma esfera à parte, separada da sociedade civil, e como uma comunidade abstrata, ilusória ou seja, a comunidade só pode existir sob a forma política, sob a forma de Estado. Nas palavras de Marx, a propriedade privada percorre uma longa história

\begin{abstract}
"até chegar ao capital moderno, condicionado pela grande indústria e pela concorrência universal, isto é, até chegar à propriedade privada pura, que se despojou de toda aparência de comunidade e que excluiu toda a influência do Estado sobre o desenvolvimento da propriedade. A esta propriedade privada moderna corresponde o Estado moderno [...]. Através da emancipação da propriedade privada em relação à comunidade, o Estado adquire uma existência particular, ao lado e fora da sociedade civil [...]" (Ideologia Alemã, p. 98).
\end{abstract}

\title{
2. A substância do Estado: escravização do trabalho pelo capital
}

\author{
"O imperialismo [Estado bonapartista] é a forma \\ mais prostituída e, ao mesmo tempo, a forma \\ mais acabada do poder estatal que a sociedade \\ burguesa nascente havia começado a criar como \\ meio de sua própria emancipação do feudalismo, \\ e que a sociedade burguesa madura acabou \\ transformando em meio para a escravização do \\ trabalho pelo capital." (A Guerra Civil na França, p. \\ 56, Boitempo).
}

Vimos que o Estado moderno se apresenta como a comunidade e que essa comunidade é ilusória na medida em que, na esfera política, são ignoradas as características particulares dos indivíduos. Vimos também que o Estado moderno, ao invés de ser a liberdade do homem, é antes a liberdade da propriedade privada moderna e, portanto, a liberdade da sociedade civil e a garantia de seu desenvolvimento desenfreado. Mas, segundo Marx, "A sociedade civil é representada positivamente pela burguesia" (Sagrada 
Família, p. 142), uma vez que ela é a classe dos proprietários. A garantia da propriedade privada significa a garantia da dominação dos proprietários privados, isto é, da burguesia. Assim, o Estado moderno se revela necessariamente como instrumento da classe burguesa para a garantia de sua propriedade e de seus interesses, ou seja, para a garantia de sua dominação enquanto classe. Como veremos adiante, o Estado moderno surge com esse objetivo e, ao longo de sua história, essa sua natureza apenas se torna cada vez mais evidente.

Se o Estado se constitui como comunidade ilusória, ao lado e fora da sociedade civil, isso não significa, de modo nenhum, que o Estado é uma entidade completamente autônoma, que paira sobre o nada, com bases próprias. Ao contrário, se é verdade que o Estado está separado e contraposto à sociedade civil, em momento nenhum deve-se perder de vista a sua base real, ou seja, as relações sociais reais nas quais o Estado se enraíza. De maneira geral, ou seja, para qualquer forma de Estado, como vimos no primeiro capítulo, Marx afirma que, com a divisão do trabalho:

"(1) o interesse coletivo toma, na qualidade de Estado, uma forma autônoma, separada dos reais interesses particulares e gerais e, ao mesmo tempo, na qualidade de uma coletividade ilusória, (2) mas sempre sobre a base real dos laços existentes em cada conglomerado familiar e tribal - tais como, laços de sangue, linguagem, divisão do trabalho em maior escala e outros interesses - e sobretudo, como desenvolveremos mais adiante, baseada nas classes, já condicionadas pela divisão do trabalho, que se isolam em cada um destes conglomerados humanos e entre as quais há uma que domina todas as outras" (Ideologia Alemã , p. 47).

Agora, nossa ênfase recai sobre o item 2, que reforça o fato de que o Estado, embora adquira uma forma autônoma e se constitua como coletividade ilusória, está sempre assentado sobre relações sociais reais; no caso do Estado moderno, sobre as classes. Em outra passagem, Marx explicita essa determinação especificamente no que se refere ao Estado moderno:

\footnotetext{
"Através da emancipação da propriedade privada em relação à comunidade, o Estado adquire uma existência particular, ao lado e fora da sociedade civil; mas este Estado não é mais do que a forma de organização que os burgueses necessariamente adotam, tanto no interior como no exterior, para a garantia recíproca de sua propriedade e de seus interesses" (Ideologia Alemã, p. 98).
} 
Marx chega a comparar o Estado a um cão de guarda da burguesia, uma vez que "os bourgeois [organizaram] a defesa da sua propriedade sob a forma do Estado" (Ideologia Alemã, v. II, p. 177). Trata-se, portanto, de reconhecer "O fato de a classe dominante constituir o seu domínio coletivo em força pública, em Estado" (Ideologia Alemã, v. II, p. 176).

Isso significa que, para Marx, o Estado está longe de ser um instrumento neutro, que foi corrompido pela burguesia. Pelo contrário, o Estado é, na sua essência, um instrumento criado para a garantia e a manutenção da propriedade privada e, portanto, da dominação da burguesia enquanto classe. Sendo assim, o interesse proclamado como geral, e ilusoriamente tido como geral, não passa do interesse médio da classe burguesa, fundado na garantia das condições materiais de sua dominação, ou seja, na escravização do trabalho pelo capital.

Definitivamente, para Marx o Estado não é um instrumento de realização da liberdade humana, como acreditavam os revolucionários de 1789. Por trás da aparente universalidade, do ilusório interesse geral proclamado pelo Estado, revela-se a particularidade concreta da dominação de uma classe sobre as outras, o interesse particular da burguesia e a garantia das condições materiais de sua dominação. Referindo-se à burguesia liberal francesa, Marx afirma:

“Em 1830, ela realizou enfim seus desejos do ano de 1789, mas com a diferença de que, agora, seu esclarecimento político já havia chegado a seu término, pois já não via no Estado representativo constitucional o ideal de Estado, não acreditava mais na aspiração de salvar o mundo, nem pensava mais em alcançar fins humanos de caráter geral, mas já havia reconhecido, muito antes, que o Estado era a expressão oficial de seu poder exclusivo e o reconhecimento político de seu interesse particular" (Sagrada Família, p. 143).

Nas Lutas de Classes na França, referindo-se ao julho de 1848, Marx é enfático ao afirmar que o proletariado obrigou a república burguesa nascente 
"a manifestar-se na sua forma pura como Estado, cujo objetivo confesso é eternizar a dominação do capital e a escravidão do trabalho" (As Lutas de Classes na França, p. 232).

Na Guerra Civil na França e em seus dois rascunhos, Marx denuncia incansavelmente essa natureza do Estado, utilizando expressões incisivas como: "instrumento de domínio de classe" (Segundo Rascunho, p. 169), "horrenda maquinaria de dominação de classe" (Primeiro Rascunho, p. 127), "maquinaria estatal, maquinaria governamental das classes dominantes" (Primeiro Rascunho, p. 138), entre muitas outras.

Porém, é preciso não perder de vista que ao longo da história há uma mudança significativa no caráter do Estado moderno, até que ele alcance o pleno desenvolvimento. 0 breve histórico do Estado moderno traçado por Marx no 18 de Brumário e na Guerra Civil na França demonstra que, se o Estado surge nos tempos do absolutismo como instrumento de luta contra o sistema feudal, com o desenvolvimento econômico da sociedade burguesa ele vai se convertendo, aos poucos e cada vez mais explicitamente, em maquinaria repressiva de escravização do trabalho, até atingir o seu ápice com o Segundo Império (Estado bonapartista). Em síntese, nas palavras de Marx,

\footnotetext{
"Esse poder estatal é, na verdade, uma criação da classe média, primeiramente [como] um meio para eliminar o feudalismo, depois [como] um meio para esmagar as aspirações emancipatórias dos produtores, da classe trabalhadora" (Primeiro Rascunho, p. 127).
}

A primeira fisionomia do Estado moderno se verifica no processo de luta contra o feudalismo, que se inicia na monarquia absoluta, tem sua coroação com a Revolução Francesa e se consuma com o Primeiro Império, com Napoleão. Esse processo de gênese do Estado moderno é o processo de centralização do poder político e da consequente separação e contraposição do Estado em relação à sociedade. No texto final da Guerra Civil na França, Marx caracteriza cada um desses momentos dessa primeira fisionomia do Estado moderno, que revela seu processo de gênese:

"O poder estatal centralizado, com seus órgãos onipresentes, com seu exército, polícia, burocracia, clero e magistratura permanentes - órgãos traçados segundo um plano de divisão sistemática e hierárquica do trabalho -, data dos temos da Monarquia absoluta, quando serviu à nascente 
sociedade da classe média como arma poderosa em suas lutas para emancipar-se do feudalismo. A Revolução Francesa do século XVIII varreu todo esse lixo dos privilégios senhoriais, locais, municipais, limpando assim o solo social dos últimos obstáculos que se erguiam ante a superestrutura final do Estado. Este recebeu sua forma final sob o Primeiro Império, o fruto das guerras de coalizão da velha Europa semifeudal contra a França moderna." (A Guerra Civil na França, Boitempo, p. 182).

Isso significa que a Revolução Francesa continuou o processo de "centralização e organização do poder do Estado" iniciado pela monarquia absoluta, intensificando "sua independência e seu poder sobrenatural sobre a sociedade real, poder que, de fato, tomou o lugar do céu sobrenatural medieval e seus santos" (Primeiro Rascunho, p. 125), até chegar ao Primeiro Império.

Entretanto, após o primeiro Bonaparte, com o início dos regimes parlamentares, há uma mudança significativa na fisionomia do Estado, causada justamente pelo desenvolvimento da sociedade burguesa enquanto tal:

"o seu caráter político mudou juntamente com as mudanças econômicas ocorridas na sociedade. No mesmo passo em que o progresso da moderna indústria desenvolvia, ampliava e intensificava o antagonismo de classe entre o capital e o trabalho, o poder do Estado foi assumindo cada vez mais o caráter de poder nacional do capital sobre o trabalho, de uma força pública organizada para a escravização social, de uma máquina do despotismo de classe. Após toda revolução que marca uma fase progressiva na luta de classes, o caráter puramente repressivo do poder do Estado revela-se com uma nitidez cada vez maior." (A Guerra Civil na França, p. 55, Boitempo).

No Segundo Rascunho, Marx apresenta a mesma ideia com algumas variações esclarecedoras:

\footnotetext{
"porque o progresso econômico da sociedade moderna inchava as fileiras da classe trabalhadora, acumulava suas misérias, organizava sua resistência e desenvolvia suas tendências à emancipação - em uma palavra, porque a moderna luta de classes, a luta entre trabalho e capital, tomava forma -, a fisionomia e o caráter do poder estatal sofreram uma notável mudança. [...] Com a entrada da própria sociedade em nova fase, a fase da luta de classes, o caráter de sua força pública organizada - o poder estatal - teve de mudar (mas também operar uma marcante mudança) e cada vez mais desenvolver seu caráter de instrumento de despotismo de classe, de engrenagem política voltada a perpetuar a escravização social dos produtores da riqueza por seus apropriadores, do domínio econômico do capital sobre o trabalho.
} 
Após cada revolução popular, resultando na transferência da direção da maquinaria estatal de um grupo das classes dominantes a outro, o caráter repressivo do Estado foi mais plenamente desenvolvido e mais impiedosamente usado, porque as promessas feitas - e aparentemente garantidas pela Revolução - só podiam ser quebradas pelo emprego da força." (Segundo Rascunho, p. 170).

Essa "notável mudança" na fisionomia e no caráter do poder estatal se inicia com a Revolução de 1830 - quando os capitalistas substituem os latifundiários no leme do Estado, agora na forma de uma monarquia parlamentar - e se consuma com a República de Fevereiro de 1848, mais especificamente após os massacres de junho. Após junho de 1848, quem assume o poder não é mais uma fração da burguesia, mas sim o "Partido da Ordem", "coalizão formada por todas as frações e facções rivais das classes apropriadoras, em seu antagonismo, agora publicamente declarado, às classes produtoras" (A Guerra Civil na França, p. 55).

Nos Rascunhos, Marx caracteriza essa nova fisionomia assumida pelo Estado a partir da República de Fevereiro da seguinte maneira:

"Durante o período da República parlamentar, o poder estatal tornou-se, enfim, o confesso instrumento da guerra, empregado pela classe apropriadora contra a massa produtora do povo" (Segundo Rascunho, p. 171)

"Todas as frações da burguesia se coligaram no Partido da Ordem, que é o partido dos proprietários e dos capitalistas, unindo-se para manter a subjugação econômica do trabalho e a maquinaria repressiva estatal que Ihe presta suporte. [...] a República era a sociedade anônima das frações burguesas coligadas, de todos os exploiteurs do povo agrupados [...]. Antagonismo direto e confesso entre seu domínio de classe e a emancipação das massas produtoras - ordem, o nome para as condições econômicas e políticas de seu domínio de classe e da servidão do trabalho, essa forma anônima ou republicana do regime burguês -, essa república burguesa, essa República do Partido da Ordem, é o mais odioso de todos os regimes políticos. Seu interesse imediato, sua única raison d'être é esmagar o povo. É o terrorismo do domínio de classe." (Primeiro Rascunho, p. 105106)

“A República parlamentar do Partido da Ordem é não apenas o reino do terror da classe dominante. O poder estatal torna-se, em suas mãos, o instrumento confesso da guerra civil nas mãos do capitalista e do proprietário fundiário, de seus parasitas estatais, contra [as] aspirações revolucionárias do produtor" (Segundo Rascunho, p. 183). 
A República parlamentar é referida por Marx ao longo do Primeiro Rascunho com expressões como "despotismo anônimo de classe" (Primeiro Rascunho, p. 106), "forma anônima do domínio de classe" (Primeiro Rascunho, p. 107), "forma republicana do despotismo de classe", "terror anônimo do domínio de classe" e "domínio anônimo de todas as frações dos pretendentes a escravocratas da França" (Primeiro Rascunho, p. 137). Ou seja, trata-se de uma forma política específica do domínio da classe dominante, na qual o Estado assume a forma de confesso instrumento de guerra do trabalho pelo capital.

Segundo Marx, essa nova fisionomia do Estado, que explicita a sua natureza intrínseca de instrumento para a manutenção da ordem burguesa, se consuma com a República do Partido da Ordem. Entretanto, ela só atinge a sua forma final, o seu mais alto grau de desenvolvimento, após o golpe de Luís Bonaparte, com o Segundo Império. A caracterização da forma política específica instaurada pelo Segundo Império revela diversos aspectos fundamentais da crítica de Marx ao Estado moderno e à política em geral. No texto final sobre a Comuna de Paris, Marx é categórico:

"O imperialismo é a forma mais prostituída e, ao mesmo tempo, a forma mais acabada do poder estatal que a sociedade burguesa nascente havia começado a criar como meio de sua própria emancipação do feudalismo, e que a sociedade burguesa madura acabou transformando em meio para a escravização do trabalho pelo capital" (A Guerra Civil na França, p. 56, Boitempo).

Ou seja, para Marx

“O Império não é, como seus predecessores - a Monarquia legítima, a Monarquia constitucional e a República parlamentar -, [apenas] uma das formas políticas da sociedade burguesa; ela é, ao mesmo tempo, sua forma mais prostituída, mais completa e acabada. O Império é o poder estatal do domínio moderno de classe, ao menos no continente europeu" (Segundo Rascunho, p. 184).

Em outras palavras,

"O que os trabalhadores tinham de derrubar era não uma mais ou menos incompleta forma do poder governamental da velha sociedade, mas sim esse poder mesmo em sua forma acabada e exaustiva: o Império." (Segundo Rascunho, p. 172). 
Ao longo dos dois rascunhos, proliferam expressões que explicitam a mesma ideia de maneira ainda mais clara. O Segundo Império deve ser compreendido, segundo Marx,

"não como uma forma peculiar de poder governamental (centralizado), mas como sua mais poderosa expressão" (Primeiro Rascunho, p. 128).

"O poder estatal recebera sua última e suprema expressão no Segundo Império" (Primeiro Rascunho, p. 126).

"o Estado parasita recebeu seu último desenvolvimento apenas durante o Segundo Império" (Primeiro Rascunho, p. 126).

"O Segundo Império foi a forma final dessa usurpação estatal" (Primeiro Rascunho, p. 127).

"O Segundo Império, o corolário final e, ao mesmo tempo, a marca definitiva da prostituição do Estado [...]" (Primeiro Rascunho, p. 128).

"Tal era o poder estatal em sua forma acabada e mais prostituída, em sua suprema e mais pérfida realidade [...]" (Segundo Rascunho, p. 172).

O Segundo Império é a forma final, acabada, mais desenvolvida etc. do poder estatal no sentido de que ele é a redução do aparelho estatal à sua natureza mais fundamental, àquilo que caracteriza o de maneira mais essencial: a manutenção da sociedade burguesa e, consequentemente, das condições de dominação da burguesia.

Quando Marx afirma que o Estado é um instrumento de dominação de classe, isso não significa que o Estado seja sempre dominado diretamente pela burguesia. A forma assumida pelo poder estatal no Segundo Império deixa isso claro, uma vez que até a própria burguesia é excluída do poder político, a fim de se garantir a preservação da ordem social burguesa.

"O Império, [...] despindo o poder estatal de sua forma direta de despotismo de classe ao frear o poder parlamentar e, portanto, o poder político direto das classes apropriadoras, esse Império era a única forma possível de Estado capaz de garantir alguma sobrevida à velha ordem social" (Segundo Rascunho, p. 171).

De um lado, temos a República parlamentar, que aparenta ser o autogoverno da sociedade. De outro, temos o Segundo Império, que aparenta ser um poder superior à sociedade, acima de todas as classes. Entretanto, a crítica de Marx demonstra que tanto 
uma como o outro são apenas duas formas políticas distintas da dominação de classe. $O$ que os diferencia é apenas a forma como essa dominação acontece: no caso da República parlamentar, o despotismo de classe é realizado diretamente, enquanto no Segundo Império, indiretamente. Na situação extrema em que a burguesia não consegue mais garantir a sua própria dominação, colocando em risco não apenas a sua dominação política, mas também a sua dominação econômica, ela é desapropriada do poder político por um poder aparentemente separado e superior a todos os interesses particulares de classe. Porém, apesar dessa aparência, e ainda que isso contrarie os interesses imediatos da burguesia, o Segundo Império é, segundo Marx, apenas a última forma possível de se garantir a perpetuação da "ordem - isto é, a 'ordem' da sociedade burguesa" (Segundo Rascunho, p. 184) ou, em outras palavras, "de se manter a 'ordem' - quer dizer, o domínio do proprietário fundiário e do capitalista sobre o produtor" (Primeiro Rascunho, p. 126-127).

\begin{abstract}
"A usurpadora ditadura do corpo governamental sobre a própria sociedade, que à primeira vista dá a impressão de elevar-se por sobre todas as classes e humilhá-las, tornou-se na verdade, ao menos no continente europeu, a única forma possível de Estado em que a classe apropriadora pode continuar a dominar a classe produtora" (Primeiro Rascunho, p. 169).
\end{abstract}

Dessa forma, dizer que o Estado é um instrumento de dominação de classe significa, mais precisamente, que o Estado é um instrumento para a garantia das condições sociais que permitem a dominação de uma classe. Assim, quando a própria burguesia, no exercício direto do poder político (República parlamentar), se torna incapaz de garantir a perpetuação de sua dominação, o Estado assume outra forma (Segundo Império), que, embora exclua a burguesia do exercício do poder político e portanto esteja em conflito com seus interesses imediatos, é a única forma capaz de garantir a sobrevivência da ordem social que permite a sua dominação. Portanto, a desapropriação política da burguesia, neste caso, está longe de ameaçar a sua dominação enquanto classe. Ao contrário, ela não apenas é a única forma possível de perpetuá-la, como ainda lhe dá pleno impulso, especialmente nos seus aspectos mais degradantes:

"Até mesmo a última expressão desse poder de Estado - o Segundo Império -, mesmo que humilhando o orgulho das classes dominantes e varrendo suas pretensões parlamentares de autogoverno, fora apenas a última forma possível de seu domínio de classe. Se, por um lado, ele 
desapropriou politicamente as classes dominantes, por outro lado, esse Estado foi a orgia sob a qual todas as infâmias econômicas e sociais de seu regime ganharam pleno impulso" (Primeiro Rascunho, p. 128).

No Segundo Rascunho, Marx é mais específico e mais incisivo:

"Por mais incômodo que possa ser para o orgulho político da classe dominante e de seus parasitas estatais, ele prova ser o regime realmente adequado à 'ordem' burguesa, na medida em que dá rédeas soltas a todas as orgias de sua indústria, às torpezas de sua especulação e a todos os esplendores meretrícios de sua vida. Assim, o Estado, aparentemente a flutuar sobre a sociedade civil, torna-se ao mesmo tempo a incubadora de todas as corrupções dessa sociedade" (Segundo Rascunho, p. 184)

Vale também acompanhar a síntese realizada por Marx no texto final, que demonstra ainda mais claramente que o Segundo Império, apesar de sua aparência de superioridade em relação à sociedade e a apesar de excluir a burguesia do poder político, deu pleno impulso à sociedade burguesa e, neste sentido, foi a incubadora de todas as corrupções dessa sociedade:

"O Império foi aclamado por todo mundo como o salvador da sociedade. Sob sua égide, a sociedade burguesa, liberta de preocupações políticas, atingiu um desenvolvimento inesperado até para ela mesma. Sua indústria e comércio assumiram proporções colossais; a especulação financeira celebrou orgias cosmopolitas; a miséria das massas contrastava com a descarada ostentação de um luxo pomposo, prostibular e vil. O poder estatal, que aparentemente pairava acima da sociedade, era, na verdade, o seu maior escândalo e a incubadora de todas as suas corrupções" (A Guerra Civil na França, p. 56) 


\title{
3. Os limites intrínsecos da liberdade política: crítica do Estado democrático
}

\begin{abstract}
Se Bauer tivesse feito o caminho correto, teria chegado "ao Estado representativo democrático, ao Estado moderno acabado [...] teria chegado primeiramente ao fato da emancipação política, ao Estado moderno desenvolvido e, portanto, ali onde podem ser contemplados e caracterizados não apenas os males relativos, mas também os males absolutos, aqueles que constituem sua própria essência" (Sagrada Família, p. 133).
\end{abstract}

A Questão Judaica é o primeiro texto de Marx que apresenta uma crítica da política enquanto tal. Seu foco é justamente uma investigação sobre a natureza da emancipação política, portanto, sobre a natureza do Estado político acabado e, portanto, sobre a política enquanto tal. Neste texto originário, os principais eixos da crítica de Marx à política já estão nitidamente presentes, embora muitos aspectos apareçam ainda de maneira incipiente. Acompanhemos, portanto, os principais momentos da argumentação de Marx.

Em meados do século XIX, o Estado alemão era um Estado cristão e, por incompatibilidade religiosa, os judeus não possuíam direitos políticos. A chamada "questão judaica", muito discutida pelos jovens hegelianos, é justamente a questão da emancipação política dos judeus na Alemanha. A Questão Judaica de Marx, redigida no final de 1843 em Kreuznach e publicada no início de 1844 ao lado da Introdução à Crítica da Filosofia do Direito de Hegel nos Anais Franco-Alemães, tem como objeto imediato o escrito homônimo de Bruno Bauer, um dos principais filósofos neo-hegelianos da época. Mas, como já indicamos, a crítica de Marx transcende a condição de mera polêmica local com Bauer, adquirindo o caráter de crítica do Estado político e, em última análise, de crítica da política.

Ao longo do texto, Marx segue basicamente o mesmo procedimento crítico: depois de expor cada uma das posições sustentadas por Bauer, trazendo à tona diversas citações do texto de seu oponente, inicia seu ataque através da simples constatação de um fato, que serve de base para o desenvolvimento positivo de sua própria posição.

No primeiro passo crítico da Questão Judaica, Marx começa expondo a posição de Bauer segundo a qual o judeu, e o homem em geral, só poderia emancipar-se como cidadão se abandonasse o judaísmo, e a religião em geral, valendo-se de diversas citações do texto de seu oponente. Diz Marx: 
“O judeu alemão, em particular, sofre da geral carência de emancipação política e do acentuado cristianismo do Estado. Mas, na acepção de Bauer, a questão judaica tem um significado geral, independente das condições especificamente alemãs. É o problema da relação entre religião e Estado, da contradição entre preconceito religioso e emancipação política. A emancipação da religião põe-se como condição, quer ao judeu que aspira à emancipação política, quer ao Estado que o deveria emancipar e emancipar-se a si próprio" (Questão Judaica, p. 37).

Segundo Marx, esta formulação da questão judaica é exclusivamente teológica. E isso, pelo fato de confinar-se às fronteiras da Alemanha, "onde não existe nenhum Estado político, nenhum Estado como tal" (Questão Judaica, p. 40), mas apenas o Estado cristão, ou seja, um Estado que ainda mantém uma atitude teológica em relação à religião. Ao tratar a questão judaica como "independente das condições especificamente alemãs", Bauer acaba por generalizá-las, chegando assim a uma contradição geral entre preconceito religioso e emancipação política.

Para Marx, porém,

"A questão judaica recebe uma formulação diferente conforme o Estado onde o judeu se encontra. [...] Só nos Estados livres da América do Norte ${ }^{21}$ pelo menos em alguns deles - é que a questão judaica perde o significado teológico e se torna questão verdadeiramente secular. Só onde o Estado político existe na sua forma plenamente desenvolvida é que a relação do judeu, do homem religioso em geral, ao Estado político, pode surgir na sua especificidade, na sua pureza. A crítica de tal relação deixa de ser teológica logo que o Estado cessa de manter uma atitude teológica perante a religião, quer dizer, quando se comporta como Estado, ou seja, politicamente. A crítica torna-se então crítica do Estado político. Neste ponto, onde a questão deixa de ser teológica, a crítica de Bauer deixa também de ser crítica" (Questão Judaica, p. 41).

Logo em seguida, apoiado em historiadores da época - como Beaumont, Tocquevile e Hamilton -, Marx traz à tona o fato de que os Estados Unidos eram, ao mesmo tempo, o país da religiosidade e o país da plena emancipação política. O que lhe permite concluir:

"Se mesmo no país da plena emancipação política descobrimos que a religião não só continua a existir, mas é viçosa e cheia de vigor, é sinal de

\footnotetext{
21 “O exemplo mais acabado do Estado moderno é a América do Norte” (Ideologia Alemã, p. 98).
} 
que a existência da religião não se opõe de nenhum modo à perfeição do Estado" (Questão Judaica, p. 41-42).

É a partir deste simples fato - que por si basta para desmontar toda a argumentação de Bauer - que Marx inicia a exposição de sua crítica da emancipação política.

Com isso, fica claro que, embora o objeto imediato de Marx na Questão Judaica sejam as ideias de Bruno Bauer, o alvo de sua crítica é o próprio Estado político plenamente desenvolvido, o Estado enquanto tal, ou - como dirá na Sagrada Família ${ }^{22}$ - o Estado moderno acabado, o Estado representativo democrático. Ou seja, a crítica de Marx não se dirige a esta ou aquela teoria política, nem a esta ou aquela forma de Estado, mas ao Estado político como tal, ao fato da emancipação política, às condições que se fundam na natureza da emancipação política (Questão Judaica, p. 39).

Primeiramente, Marx explica a natureza da emancipação política partindo do caso específico da religião e, logo em seguida, generaliza as conclusões para qualquer pressuposto do Estado, como por exemplo a propriedade privada.

Segundo Marx, o Estado se emancipa da religião do modo que corresponde à sua natureza, ou seja, libertando-se da religião de Estado. Isso significa que a religião é expulsa do Estado e que o Estado, enquanto tal, não reconhece mais nenhuma religião: o Estado tornou-se ateu. Mas a religião continua a existir na realidade. Assim, conclui Marx,

"Os limites da emancipação política aparecem imediatamente no fato de o Estado poder libertar-se de um constrangimento ${ }^{23}$ sem que o homem se

\footnotetext{
${ }^{22}$ No capítulo VI da Sagrada Família, Marx retoma explicitamente a polêmica com Bauer a respeito da questão judaica.

${ }^{23} \mathrm{Na}$ Questão Judaica, Marx se refere à religião como um "constrangimento", um "defeito". A posição de Marx sobre a religião, que na Questão Judaica está pressuposta, é desenvolvida logo nas primeiras páginas da Introdução à Crítica da Filosofia do Direito de Hegel, texto escrito poucos meses depois da Questão Judaica (entre dezembro de 1843 e janeiro de 1844) e publicado no mesmo periódico, os Anais Franco-Alemães. Marx abre o texto concordando com os neo-hegelianos quanto ao fato de que a religião é um produto do próprio homem e de que este homem é um homem distante de si mesmo, alienado, uma vez que se reflete como ser celestial, em oposição à sua realidade terrena. Entretanto, acrescenta Marx superando a crítica neo-hegeliana, a inversão que o homem opera na religião não é mero produto da sua consciência, não é simplesmente causada por um erro de compreensão, como se a correção deste erro levasse ao fim da religião. Diferentemente, o homem, que na sua consciência se separa de si e se vê como criatura de Deus, não é um ser abstrato, isto é, isolado, fechado em si mesmo, independente do mundo; não é pura consciência. O homem é o mundo dos homens, o Estado, a sociedade. Assim, se ocorre uma inversão na consciência (como é o caso da religião), esta inversão é produto de um mundo (um Estado, uma sociedade) que é ele mesmo invertido. Para
} 
encontre realmente liberto; de o Estado conseguir ser um Estado livre sem que o homem seja um homem livre" (Questão Judaica, p. 43). Em outras palavras, "A emancipação do Estado a respeito da religião não é a emancipação do homem real quanto à religião" (Questão Judaica, p. 53).

O mesmo vale para qualquer outro elemento particular, seja espiritual ou material, uma vez que, segundo Marx,

\begin{abstract}
"A elevação política do homem por cima da religião compartilha todas as carências e todos os méritos da elevação política em geral" (Questão Judaica, p. 43).
\end{abstract}

Acompanhemos a análise do caso específico da propriedade privada:

"Por exemplo, o Estado como Estado abole a propriedade privada (isto é, o homem, de modo político, decreta a abolição da propriedade privada), ao abolir o censo para a elegibilidade ativa e passiva, como aconteceu em muitos Estados da América do Norte" (Questão Judaica, p. 44).

A abolição política da propriedade privada significa, assim como no caso da religião, a expulsão da propriedade privada da esfera do Estado. O Estado, enquanto Estado, não reconhece mais distinções de propriedade. Isso, concretamente, se traduz na abolição do censo eleitoral. Depois de enunciar o fato, Marx expõe seus méritos e seus limites:

"Hamilton interpreta este fato de modo inteiramente correto do ponto de vista político. As massas alcançaram uma vitória sobre os detentores da propriedade e sobre a riqueza financeira. Não se encontrará a propriedade privada idealmente abolida quando o não proprietário se tornou o legislador do detentor da propriedade? O censo é a última forma política em que se reconhece a propriedade privada" (Questão Judaica, p. 44).

Marx concorda com Hamilton quando este afirma que a abolição do censo significa uma vitória das massas sobre os detentores de propriedade e, assim, reconhece o mérito da abolição política da propriedade privada. Porém, simultaneamente, evidencia que essa vitória e esse mérito são reais apenas do ponto de vista político. Isso porque, assim como no caso da religião, a propriedade privada foi abolida apenas na esfera do Estado,

Marx, portanto, a inversão no plano da consciência (no caso, a religião) é produto, expressão e complemento ideal da inversão no plano real. 
politicamente, idealmente, mas continua a existir na realidade. Com isso, Marx demonstra novamente que a liberdade política não coincide com a liberdade real do homem.

“Mas a supressão política da propriedade privada não abole unicamente a propriedade; pressupõe de fato a sua existência" (Questão Judaica, p. 44).

Aqui, através do exemplo da propriedade privada, Marx revela uma outra determinação fundamental da natureza da emancipação política: o Estado pressupõe a existência efetiva dos elementos particulares que expulsa de sua esfera. Vimos que a abolição política da propriedade privada e da religião não significa a abolição efetiva da propriedade privada, nem da religião. Agora, Marx evidencia que o Estado nem sequer procura abolir esses elementos; ao contrário, pressupõe a sua existência efetiva. Só se constitui enquanto Estado por cima desses elementos particulares. É nesta passagem que Marx estende as conclusões sobre a relação do Estado com a religião para qualquer elemento que compõe a vida real da nação:

"O Estado elimina, à sua maneira, as distinções estabelecidas por nascimento, posição social, educação e profissão, ao decretar que o nascimento, a posição social, a educação e a profissão são distinções não políticas; ao proclamar, sem olhar a tais distinções, que todo o membro do povo é igual parceiro da soberania popular, e ao tratar do ponto de vista do Estado todos os elementos que compõem a vida real da nação. No entanto, o Estado permite que a propriedade privada, a educação e a profissão atuem à sua maneira, a saber: como propriedade privada, como educação e profissão, e manifestem a sua natureza particular" (Questão Judaica, p. 44).

Portanto,

"Longe de abolir estas diferenças efetivas, ele só existe na medida em que as pressupõe; apreende-se como Estado político e revela a sua universalidade apenas em oposição a tais elementos. [...] Não há dúvida! Unicamente assim, por cima dos elementos particulares, é que o Estado se constitui como universalidade" (Questão Judaica, p. 44-45).

Assim, o Estado se apresenta como esfera da universalidade em oposição, em contradição com a particularidade dos elementos reais da vida. 
“O Estado político aperfeiçoado é, por natureza, a vida genérica do homem em oposição à sua vida material. Todos os pressupostos da vida egoísta continuam a existir na sociedade civil, fora da esfera política, como propriedade da sociedade civil" (Questão Judaica, p. 45).

Dada essa oposição, o homem tem a sua vida duplicada: "Vive na comunidade política [isto é, no Estado], em cujo seio é considerado um ser comunitário, e na sociedade civil, onde age como simples indivíduo privado", egoísta, oposto aos outros homens. Porém, no Estado, “onde é olhado como ser genérico, o homem é o membro imaginário de uma soberania imaginária, despojado de sua vida real individual, e dotado de universalidade irreal" (Questão Judaica, p. 46). Isso revela o caráter abstrato e sofístico da própria qualidade da cidadania e, portanto, do próprio Estado político. Partindo do exemplo concreto do judeu, Marx afirma:

"É verdade que o bourgeois [isto é, o membro da sociedade civil], tal como o judeu, participa na vida política só de modo sofístico, assim como o citoyen [isto é, o membro do Estado político] é judeu ou bourgeois só sofisticamente. Mas a sofisticação não é pessoal. É a sofisticação do próprio Estado político. A diferença entre o homem religioso e o cidadão é a diferença entre o comerciante e o cidadão, entre o jornaleiro [assalariado] e o cidadão, entre o proprietário de terras e o cidadão, entre o indivíduo vivo e o cidadão. A contradição em que o homem religioso se encontra com o homem político é igual à contradição em que o bourgeois se vê com o citoyen e o membro da sociedade civil com a sua política pele de leão" (Questão Judaica, p. 46).

Eis que, partindo da questão judaica, Marx nos leva até a contradição entre o Estado político e a sociedade civil, a qual é revelada como expressão da contradição entre a vida individual e a vida genérica do homem.

Uma leitura cuidadosa do texto de Marx é suficiente para demonstrar que, na Questão Judaica, vida genérica aparece sempre como um sinônimo de vida comunitária, social. Quando Marx afirma: "a própria vida genérica - a sociedade -" (Questão Judaica, p. 58), está apresentando explicitamente a sociedade como um sinônimo de vida genérica do homem. No final do primeiro artigo, Marx especifica essa categoria, apresentando-a como as forças sociais do homem, que, nesta organização da sociedade, são alienadas sob a forma de força política. 
Na primeira vez em que a expressão aparece na Questão Judaica, Marx afirma que "O Estado político aperfeiçoado é, por natureza, a vida genérica do homem em oposição à sua vida material" (Questão Judaica, p. 45). Em seguida, explica que, no Estado, o homem é um ser apenas imaginariamente comunitário (isto é, genérico), uma vez que tem sua individualidade real completamente anulada nesta esfera; porém, na sociedade civil, onde existe como indivíduo real, surge como um ser concretamente isolado, egoísta, oposto aos outros homens, como um ser anti-social. Sendo assim, Marx revela uma contradição entre o Estado, "onde o homem se comporta, se bem que de maneira limitada e numa forma e esfera particular, como ser genérico, em comunidade com os outros homens", e a sociedade civil, que surge como a "esfera do egoísmo e do bellum omnium contra omnes [guerra de todos contra todos]" (Questão Judaica, p. 47), uma vez que nesta esfera foram rompidos todos os laços genéricos do homem (Questão Judaica, p. 72). ${ }^{24}$

Esse percurso conduz Marx à denúncia dos limites intrínsecos da emancipação política, identificada agora como uma fase limitada e transitória do processo de construção da liberdade humana:

\begin{abstract}
"A emancipação política representa, sem dúvida, um grande progresso. Não constitui, porém, a forma final de emancipação humana, mas é a forma final de emancipação humana dentro da ordem mundana até agora existente. Nem vale a pena dizer que estamos aqui a falar de emancipação real, prática" (Questão Judaica, p. 47).
\end{abstract}

Aqui, surge uma nova determinação: a emancipação política é a forma final de emancipação humana dentro da ordem mundana até agora existente. Assim como antes Marx dizia que a religião permanece como forma de consciência dos cidadãos livres porque ela é a forma ideal de um "estágio evolutivo humano", agora dá um passo além e afirma que a emancipação política é o nível máximo de emancipação humana dentro da ordem

\footnotetext{
${ }^{24}$ Isso demonstra que o gênero humano ou a vida genérica do homem está longe de ser para Marx uma qualidade natural da espécie humana, uma essência imutável, de caráter a-histórico, comum a todos os indivíduos. Ao contrário, como é nítido em todo o percurso da Questão Judaica, para Marx a vida genérica, isto é, a vida comunitária, social do homem possui caráter histórico, ou seja, assume uma forma diferente conforme a organização da sociedade. Esta organização social, ao destituir as forças sociais dos próprios indivíduos e aliená-las sob a forma de força política, gera o conflito entre a vida individual e a vida genérica do homem, entre o indivíduo vivo e o cidadão abstrato, entre os interesses gerais e os interesses particulares, enfim, entre a sociedade civil e o Estado político.
} 
mundana até agora existente. Isso implica, desde já, que a superação da religião e da emancipação política envolve necessariamente a superação de toda a "ordem mundana até agora existente", identificada por Marx no texto à propriedade privada, à troca e seus pressupostos.

Desde o início, Marx enfatiza que sua crítica se dirige à própria emancipação política, às condições que se fundam na natureza da emancipação política e, com isso, revela os limites intrínsecos da emancipação política. Isso significa que, segundo Marx, não há como corrigir os seus defeitos, pois a limitação não é pessoal ou contingente, mas reside "na natureza e na categoria da emancipação política" (Questão Judaica, p. 53). Para não deixar dúvidas, Marx insiste:

\begin{abstract}
"Mas ninguém deve iludir-se quanto aos limites da emancipação política. A cisão do homem em pessoa pública e pessoa privada, o deslocamento da religião do Estado para a sociedade civil, não é uma fase, mas a consumação da emancipação política. Desta maneira, a emancipação política não abole, nem sequer procura abolir, a religiosidade real do homem" (Questão Judaica, p. 48).
\end{abstract}

E continua:

"A desintegração do homem em judeu e cidadão, protestante e cidadão, homem religioso e cidadão, não é uma fraude praticada contra o sistema político, nem sequer um subterfúgio da emancipação política. É a própria emancipação política, o modo político de se emancipar da religião" (Questão Judaica, p. 48).

Na Sagrada Família, ao retomar a polêmica com Bauer, Marx reitera essa ideia de forma ainda mais enfática, afirmando que sua crítica se dirige não aos males relativos, mas aos males absolutos da emancipação política, os quais só podem ser contemplados no Estado moderno desenvolvido, isto é, o Estado representativo democrático, onde a emancipação política está realizada de forma plena. Segundo Marx, se Bauer tivesse feito o caminho correto, teria chegado

"ao Estado representativo democrático, ao Estado moderno acabado [...] teria chegado primeiramente ao fato da emancipação política, ao Estado moderno desenvolvido e, portanto, ali onde podem ser contemplados e caracterizados não apenas os males relativos, mas também os males absolutos, aqueles que constituem sua própria essência" (Sagrada Família, p. 133). 


\section{O Estado parasita: o poder político como força social usurpada}

No início de sua produção teórica madura, no período que vai da Questão Judaica até a Ideologia Alemã, Marx identifica o poder político como forma alienada do poder social. Mais tarde, a partir das Lutas de Classes na França, mas principalmente nos textos sobre a Comuna, Marx não fala mais em alienação, e sim em usurpação. Essa mudança de termos, longe de significar uma mudança na posição teórica de Marx, ao contrário, demonstra um aprofundamento que simultaneamente esclarece e concretiza o significado desse processo de separação das forças sociais do corpo da sociedade.

Assim como nos Manuscritos de 1844 Marx demonstrava que o outro lado da alienação do trabalho é a apropriação do seu produto por um terceiro, ou seja, que o fruto necessário do trabalho alienado é a propriedade privada, assim também, no que se refere à política, Marx demonstra que, se de um lado as forças sociais são alienadas do corpo da sociedade, por outro, elas são apropriadas por um órgão estranho, o Estado. Se no início a ênfase de Marx recaía sobre a alienação, mais tarde recairá sobre a apropriação dessas forças sociais, e o Estado aparecerá então como usurpador, como parasita das forças sociais.

A partir da instauração do Estado moderno - que como vimos é indissociável da instauração da propriedade privada moderna e da consequente quebra de todos os laços comunitários - tudo o que diz respeito à comunidade (interesses comuns) deixa de ser atribuição dos próprios membros da sociedade e passa a ser atribuição do poder estatal centralizado. No 18 de Brumário, Marx nos fornece uma das raras e preciosas concretizações desse fato:

\footnotetext{
"Todo e qualquer interesse comum foi imediatamente desvinculado da sociedade e contraposto a ela como interesse mais elevado, geral, subtraído à atividade dos próprios membros da sociedade e transformado em objeto da atividade governamental, desde a ponte, o prédio escolar e o patrimônio comunal de um povoado até as ferrovias, o patrimônio nacional e a universidade nacional da França" (18 de Brumário, p. 141).
}

Depois de diferenciar o interesse comum, enquanto verdadeiro interesse da comunidade, do interesse geral, enquanto interesse comum ilusório, separado da comunidade e a ela contraposto na forma de Estado, Marx afirma que o interesse comum foi 
subtraído da própria sociedade e atribuído ao poder governamental. Com isso, o Estado se configura como uma

"terrível corporação de parasitas, que envolve o organismo da sociedade francesa como uma membrana e entope todos os seus poros" (18 de Brumário, p. 140).

Nos textos sobre a Comuna, Marx apresenta formulações muito semelhantes, porém com imagens ainda mais enfáticas, todas elas ressaltando a separação e a oposição violenta do Estado em relação à sociedade civil. No Primeiro Rascunho, proliferam expressões como "Estado parasita", "usurpação estatal", "pesadelo sufocante", "excrescência parasitária", "aborto sobrenatural da sociedade" (Primeiro Rascunho, p. 126-127). No Segundo Rascunho, Marx é ainda mais enfático, quando se refere ao Estado como uma "enorme maquinaria governamental, que como uma jiboia constringe o verdadeiro corpo social" ou como

"O enorme parasita governamental, constringindo o corpo social como uma jiboia na malha ubíqua de sua burocracia, polícia, exército permanente, clero e magistratura" (Segundo Rascunho, p. 169-170).

No texto final, Marx mantém o tom, referindo-se ao Estado como "autoridade que usurpava a preeminência sobre a própria sociedade" (A Guerra Civil na França, p. 241). Ou então ao afirmar que

\footnotetext{
"O regime comunal teria restaurado ao corpo social todas as forças até então absorvidas pelo parasita estatal, que se alimenta da sociedade e obstrui seu livre movimento" (A Guerra Civil na França, p. 59, Boitempo).
}

\section{Fechamento}

Neste capítulo, analisamos alguns dos principais elementos da crítica de Marx ao Estado moderno. Começamos pelo seu processo de gênese, ou seja, pela caracterização do Estado enquanto fruto necessário e indissociável da propriedade privada moderna, que rompe os laços comunitários e faz com que os interesses comuns assumam a forma autônoma e abstrata de interesses gerais, constituindo-se enquanto Estado. Desde já, o 
Estado moderno aparece socialmente enraizado, como uma construção edificada sobre a base real da propriedade privada e, portanto, indissociável da ordem do capital e da dominação de classe.

Em seguida, analisamos duas formas específicas assumidas pelo Estado ao longo da história, a democracia e o Estado bonapartista. Embora diametralmente opostas, ambas são referidas por Marx como a forma mais desenvolvida, a forma acabada ou a forma final do Estado moderno e, enquanto tais, explicitam características e limites intrínsecos ao Estado moderno. Entretanto, essa qualificação assume sentidos bem distintos em cada um dos casos.

Para Marx, a democracia é a forma final do Estado moderno no sentido de que é o grau máximo de emancipação possível no interior da esfera política, ou seja, é a forma final da emancipação política. Em outras palavras, a forma democrática é a forma mais desenvolvida de Estado do ponto de vista da capacidade de realização da liberdade humana. Já o Estado bonapartista é referido por Marx como a forma final do Estado moderno no sentido de que ele é a encarnação nua e crua de sua essência mais íntima, de sua substância - a escravização do trabalho pelo capital. Isso significa que qualquer forma assumida pelo Estado, desde a sua forma mais perfeita do ponto de vista da liberdade, a democracia, até a sua última e suprema expressão do ponto de vista de sua natureza, o Estado bonapartista, será sempre uma forma organizada de escravização do trabalho pelo capital. Essas duas formas, cada uma à sua maneira, explicitam características e limitações intrínsecas ao Estado enquanto tal.

Sua última e suprema expressão, o Estado bonapartista, ao excluir a burguesia do poder político com a finalidade de garantir a perpetuação da ordem do capital, revela que o Estado não está colado aos interesses imediatos da burguesia e não implica necessariamente a sua dominação política direta. Sendo assim, o Estado é instrumento de dominação de classe, mas não no sentido de garantir os interesses imediatos da burguesia, e sim no sentido de garantir as condições que permitem que a burguesia exerça a sua dominação enquanto classe, ou seja, de garantir a ordem do capital e, com ela, a escravização do trabalho. A retirada da burguesia do cenário político, nesse caso, corresponde a um enorme desenvolvimento da sociedade burguesa, especialmente em seus aspectos econômicos e sociais mais degradantes. 
Já a forma de Estado mais desenvolvida do ponto de vista da liberdade humana, a democracia, revela não apenas os limites relativos do Estado moderno, mas também seus limites absolutos, ou seja, seus limites intrínsecos e portanto intransponíveis. A forma democrática do Estado, enquanto máximo grau possível de liberdade na esfera estatal, ou, em outras palavras, a plena emancipação política, não efetiva a liberdade real do homem, mas apenas dos elementos estranhados da sua vida, ou seja, do mundo da propriedade privada. Sendo assim, a democracia, atualmente cultuada como a forma final da liberdade humana, é identificada por Marx como a forma final da liberdade humana apenas dentro da ordem do capital.

Isso não significa que, para Marx, o aperfeiçoamento do Estado seja desprezível, mas apenas que ele é intrinsecamente limitado e insuficiente. O Estado, mesmo na sua forma mais livre, a democracia, não deixa de ser Estado, portanto, não deixa de ser forma organizada de escravização do trabalho pelo capital. Ao mesmo tempo, isso não significa de maneira nenhuma que a forma de Estado seja indiferente à burguesia ou aos trabalhadores. Ao longo da história, conforme as lutas da classe trabalhadora avançam, mais o Estado tende a se retrair, para garantir a continuidade da ordem do capital. No 18 de Brumário, referindose à burguesia, Marx afirma:

"Foi a sensação de debilidade que os fez recuar diante das condições puras do seu próprio domínio de classe e ansiar por retornar às formas mais incompletas, mais subdesenvolvidas e, por isso mesmo, menos perigosas de tal domínio" (18 de Brumário, p. 62)

Nem o Estado bonapartista é um poder que está acima da própria sociedade, nem a democracia é o autogoverno da sociedade. Para Marx, trata-se de desconstruir estas ilusões, através do reconhecimento de que o Estado, inclusive na sua forma mais livre, a democracia, é um usurpador do poder de auto-organização da sociedade. E, na prática, trata-se de restituir ao corpo da sociedade esse poder que Ihe foi usurpado, o que só é possível através da extinção do Estado. Sendo assim, para Marx, não existe um para-além da democracia que não seja ao mesmo tempo um para-além do Estado e da política enquanto tal. 


\title{
III. CRÍTICA DO DIREITO E DOS DIREITOS HUMANOS
}

\author{
"No que toca ao direito, já sublinhamos, aliás \\ como muitos outros, a oposição entre o \\ comunismo e o direito, quer se trate do público, \\ do privado ou da sua formulação mais genérica \\ enquanto direitos do homem." (Ideologia Alemã, \\ v. I, p. 265).
}

Este capítulo será dividido em três partes: 1) crítica do direito, 2) crítica dos direitos humanos e 3) igualdade e liberdade como categorias da troca de equivalentes.

A primeira, a crítica do direito em geral, começará expondo a base real do direito, ou seja, a vinculação orgânica entre o direito e as relações materiais de vida, mais especificamente as relações de produção, evidenciando que o direito não cria essas relações, mas, ao contrário, é um produto delas, é a sua expressão jurídica. Aqui, o direito é concebido em seu sentido mais amplo, designando as relações jurídicas de qualquer modo de produção, não apenas do capitalismo. A crítica apresentada no primeiro capítulo à política em geral aplica-se inteiramente ao direito neste sentido mais amplo.

Em segundo lugar, o direito será oposto ao privilégio, o primeiro correspondendo ao modo de produção capitalista e o segundo ao modo de produção medieval. Aqui, direito ganha o sentido específico de relações jurídicas correspondentes à propriedade privada moderna; trata-se agora do direito propriamente dito, do direito puro e simples, isto é, do direito igual, o direito burguês. Esse direito será criticado tanto em seu conteúdo, identificado como expressão geral da vontade da classe dominante e portanto baseado na força, quanto em sua forma, que por sua natureza desconsidera as particularidades individuais, fazendo do direito, inevitavelmente, o direito da desigualdade - este último aspecto, relativo à forma, será exposto com base na Crítica ao Programa de Gotha.

Em terceiro lugar, será analisada a crítica de Marx à ilusão jurídica, especificamente no que se refere ao direito de propriedade privada, isto é, ao jus utendi e abutendi, tal como desenvolvida no primeiro capítulo da Ideologia Alemã. Essa crítica, no entanto, será retomada com maior detalhe no próximo capítulo.

Na segunda parte, o objeto será a crítica de Marx aos direitos humanos. Em primeiro lugar, tendo como base a Questão Judaica e a Sagrada Família, os direitos humanos serão apresentados como direitos da sociedade civil, ou seja, não do homem enquanto tal, mas do 
homem burguês, o homem egoísta, separado dos outros homens e da comunidade, produto da propriedade privada moderna. Assim, os direitos humanos não significam a liberdade do homem, mas sim a liberdade dos elementos estranhados da vida burguesa e, por consequência, a sanção de sua própria escravidão. Trata-se, antes, da liberdade da propriedade privada em relação ao privilégio.

Em segundo lugar, será abordado o que Marx chama de enigma ou ilusão de ótica da consciência dos revolucionários. Aqui, será explicado por que, nas Declarações, o homem da sociedade civil aparece como homem natural, por que os direitos humanos aparecem como direitos naturais, por que a vida política é declarada como simples meio para a garantia da vida da sociedade civil e por que o homem da sociedade civil aparece como o homem verdadeiro e autêntico.

Em terceiro lugar, será analisado o único momento em que Marx se refere uma contradição entre a teoria e a prática dos direitos, que se limita ao momento do Terror revolucionário francês. E desde já será indicado que, ao contrário do que sustenta a imensa maioria dos intérpretes, não há em Marx nada parecido com uma crítica da abstração dos direitos humanos e, além disso, não há como compatibilizar sua teoria com a defesa dos direitos humanos e do direito em geral, a não ser através da desconsideração da especificidade do tratamento que confere ao tema.

Na terceira e última parte, o ponto de partida será a análise dos direitos humanos enquanto direitos da troca de mercadorias. Indo além, a igualdade e a liberdade serão analisadas como categorias intrínsecas à troca de equivalentes e esta será apresentada como a base produtiva, real, de toda igualdade e liberdade, ou seja, tanto como ideias puras quanto como desenvolvidas em relações jurídicas, políticas e sociais. Isso significa que, para Marx, a igualdade e a liberdade políticas e jurídicas em geral - não apenas nos direitos humanos - têm como fundamento real a troca de equivalentes e, nesse sentido, são precisamente essa base em outra potência.

Em seguida, será analisada a crítica de Marx à tolice dos socialistas que entendem o socialismo como a realização efetiva, verdadeira, correta, da igualdade e da liberdade burguesas. Aqui, será demonstrado que a liberdade e a igualdade são de fato respeitadas na troca de mercadorias, que a sua realização se dá necessariamente como realização da desigualdade e da ausência de liberdade e que essas contradições não são uma fraude 
contra o sistema burguês, ou uma corrupção da sua verdadeira natureza. Ao contrário, essas contradições lhes são imanentes. Por fim, essa crítica será relacionada à crítica de Marx aos direitos humanos e à emancipação política. Toda essa terceira parte será desenvolvida com base no Capital e principalmente nos Grundrisse.

\section{Crítica do direito}

"o direito não concede nada, mas apenas se limita a sancionar o existente" (Sagrada Família, p. 214).

A certa altura da Crítica ao Programa de Gotha, Marx faz uma pergunta indignada a Lassalle:

\footnotetext{
"As relações econômicas são reguladas por conceitos jurídicos ou, ao contrário, são as relações jurídicas que derivam das relações econômicas?" (Crítica de Gotha, p. 27).
}

Essa pergunta, que está presente na sua obra desde a Crítica da Filosofia do Direito de Hegel, de 1843, já foi respondida diversas vezes, no que se refere às relações políticas em geral. Como vimos no Capítulo 1, para Marx as relações políticas e jurídicas não podem ser compreendidas como entidades autônomas, mas apenas em sua vinculação orgânica com as relações de produção. Aqui, trata-se de reiterar essa posição no que se refere especificamente ao direito, tomado na sua acepção geral. Na Introdução de 1857, Marx é categórico:

"cada forma de produção cria suas próprias relações de direito, formas de governo, etc. A grosseria e a incompreensão consistem em não relacionar, senão fortuitamente, uns aos outros, em não enlaçar, senão como mera reflexão, elementos que se acham unidos organicamente." (Introdução de 1857, p. 7).

Segundo Marx, as relações de direito, isto é, as relações jurídicas, assim como as formas de governo e as relações políticas em geral, possuem um vínculo orgânico com as 
relações de produção. Não se trata de uma conexão contingente, mas sim de uma conexão necessária. Determinadas relações de produção criam determinadas relações de direito. Ou, em outras palavras, determinadas formas econômicas da sociedade criam determinadas formas jurídicas. Sendo assim,

"O direito nunca pode ultrapassar a forma econômica e o desenvolvimento cultural, por ela condicionado, da sociedade" (Crítica de Gotha, p. 31, Boitempo).

Dito de outra forma, o direito está organicamente vinculado à propriedade. No Prefácio de 1859, Marx identifica explicitamente as relações de propriedade como expressão jurídica das relações de produção:

\footnotetext{
"Em uma certa etapa do desenvolvimento, as forças produtivas materiais da sociedade entram em contradição com as relações de produção existentes ou, o que nada mais é do que a sua expressão jurídica, com as relações de propriedade dentro das quais aquelas até então se tinham movido" (Prefácio de 1859, p. 30).
}

Como podemos notar, embora somente a sociedade capitalista desenvolva o direito propriamente dito, existem diversas afirmações de Marx que se referem ao direito de maneira abrangente, ou seja, incluindo outras formas sociais que não a capitalista. Nesta acepção geral, o direito designa a forma jurídica assumida pelas relações materiais de produção em cada período da história.

Sendo assim, para Marx, o direito está longe de ser um conjunto de leis criadas a partir do nada, de maneira autônoma, que determinam a forma da sociedade. Ao contrário, determinadas formas sociais, baseadas em determinadas formas de produção, criam necessariamente determinadas formas jurídicas. Antes de tudo, portanto, o direito é um produto indissociável das relações materiais de produção. 


\subsection{O conteúdo do direito: propriedade privada, dominação de classe e força}

Cada modo de produção gera determinadas relações jurídicas, mas o direito propriamente dito, o direito puro e simples, é um produto específico da sociedade capitalista. Trata-se, agora, do direito burguês, em oposição a outras formas jurídicas, como o privilégio medieval, por exemplo. No que se refere ao seu conteúdo, portanto, o direito é antes de tudo um produto necessário e indissociável da propriedade privada moderna.

Marx sustenta essa vinculação orgânica entre o direito burguês e a propriedade privada moderna já desde a Questão Judaica e a Sagrada Família, ainda que em outros termos. Na Questão Judaica, Marx afirma:

\footnotetext{
"A constituição do Estado político e a dissolução da sociedade civil em indivíduos independentes, cujas relações são regulamentadas por lei, da mesma maneira que as relações entre os homens nas ordens e guildas eram reguladas por privilégio, cumprem-se num só e mesmo ato" (Questão Judaica, p. 62).
}

Tanto o privilégio como o direito aparecem como formas de regulação social determinadas por uma base social específica. Se no sistema feudal as relações entre os homens são reguladas pelo privilégio, no sistema capitalista, isto é, com o surgimento da propriedade privada moderna e a consequente dissolução da sociedade civil em indivíduos independentes, as relações passam a ser reguladas pela lei, isto é, pelo direito.

Desde já fica evidente que, para Marx, o direito não é um meio de realização da liberdade humana, um instrumento autônomo forjado a partir da vontade pura para tal magnânima finalidade, mas sim uma forma de regulação social baseada na sociedade civil moderna e, portanto, na propriedade privada desenvolvida, que rompe todos os laços comunitários, ao mesmo tempo tornando os indivíduos independentes e opostos entre si e constituindo a comunidade na forma abstrata e estranha de Estado. Ou seja, o direito para Marx não é nada além da forma de regulação social da escravidão moderna e, enquanto tal, ironicamente, uma nova forma de privilégio. Na Sagrada Família, Marx é tão sarcástico quanto incisivo:

"A antítese entre o Estado representativo democrático e a sociedade burguesa é a culminação da antítese clássica entre a comunidade pública e 
a escravidão. No mundo moderno, todos são, a um só tempo, membros da escravidão e da comunidade. Precisamente a escravidão da sociedade burguesa é, em aparência, a maior liberdade, por ser a independência aparentemente perfeita do indivíduo, que toma o movimento desenfreado dos elementos estranhados de sua vida, já não mais vinculados pelos nexos gerais nem pelo homem, por exemplo, o movimento da propriedade, da indústria, da religião etc., por sua própria liberdade, quando na verdade é, muito antes, sua servidão e sua falta de humanidade completas e acabadas. O privilégio é substituído aqui pelo direito" (Sagrada Família, p. 135).

O direito aparece aqui, assim como em toda a Questão Judaica, como forma de regulação da escravidão da sociedade burguesa e, portanto, não como a libertação real do homem, mas sim como a libertação da propriedade privada, que agora, livre de todo vínculo comunitário, pode se movimentar freneticamente. O direito, que segundo a ilusão jurídica seria o instaurador da liberdade humana, aparece em Marx, sem rodeios, como direito à escravidão.

Na Ideologia Alemã, Marx referenda e reitera essa mesma posição, de maneira ainda mais incisiva:

\footnotetext{
"Ver os Anais franco-alemães, onde o privilégio é considerado como correspondendo à propriedade privada ligada a um estado [nota de Marx: "na acepção que a palavra toma na expressão 'terceiro estado'"], e o direito como correspondendo às condições da concorrência, da propriedade privada livre [...]" (Ideologia Alemã, v. I, p. 265)
}

Marx se refere ao privilégio e ao direito como expressões jurídicas específicas correspondentes a formas determinadas da propriedade privada: o privilégio à propriedade privada ainda não completamente desenvolvida, ou seja, à propriedade privada ainda ligada a um estamento, e o direito à propriedade privada livre, isto é, à propriedade privada moderna, capitalista. Mais adiante, ironizando o procedimento idealista de Max Stirner (que aqui não nos vem ao caso), Marx reafirma a mesma posição:

\footnotetext{
"Tal atitude evita-Ihe ter de saber alguma coisa sobre o modo de produção medieval, que tem como expressão política o privilégio, e sobre o modo de produção moderno, que tem como expressão o direito puro e simples, o direito igual, e, também, sobre as relações entre estes dois modos de produção e as relações jurídicas que Ihes correspondem" (Ideologia Alemã, v. II, p. 133)
} 
Ao longo toda a Ideologia Alemã, é nítido o esforço de Marx em demonstrar que, diferentemente do que reza a superstição política, o direito não é baseado na vontade, muito menos na vontade destacada de sua base real, a "vontade soberana", mas, ao contrário, se fundamenta nas relações materiais, mais especificamente nas relações de propriedade e, portanto, não possui uma história própria: “Não se deve esquecer que tanto o direito quanto a religião não têm história própria" (Ideologia Alemã, p. 99).

No primeiro capítulo, no item "A relação do Estado e do Direito com a Propriedade", Marx é ainda mais específico acerca do condicionamento do direito pela propriedade privada. Sendo ele, "O direito privado desenvolve-se simultaneamente com a propriedade privada" (Ideologia Alemã, p. 98). Por exemplo, "Amalfi, a primeira cidade da Idade Média que teve um extenso comércio marítimo, foi também a primeira a elaborar o direito marítimo" (Ideologia Alemã, p. 99). Sendo assim, cada novo desenvolvimento da propriedade privada implica necessariamente um novo desenvolvimento do direito:

"Cada vez que, através do desenvolvimento da indústria e do comércio, surgem novas formas de intercâmbio (por exemplo, companhias de seguro etc.), o direito tem sido sempre obrigado a admiti-las entre os modos de adquirir propriedade" (Ideologia Alemã, p. 101).

Uma vez reconhecido o seu efetivo enraizamento nas relações materiais de produção, o direito é despido de sua aura mística libertadora, de tal maneira que seus axiomas, longe de conduzirem à superação do capital, são explicitamente revelados enquanto axiomas da propriedade privada. Enquanto tais, só podem ter como conteúdo os interesses da classe apropriadora, isto é, da classe dominante.

Assim como o direito não é e nem pode ser revolucionário, assim também não é e não pode ser neutro. Como expressão das relações da propriedade privada moderna, o direito só pode ser a expressão da vontade da classe dominante. Para Marx, portanto, o direito moderno, o direito burguês, é a vontade da classe dominante elevada a lei:

"As vossas próprias ideias são produtos das relações de produção e propriedade burguesas, tal como o vosso direito é apenas a vontade da 
vossa classe elevada a lei, uma vontade cujo conteúdo está dado nas condições materiais de vida da vossa classe" (Manifesto Comunista, p. 121).

Porém, a vontade da classe dominante não é uma vontade autônoma, que paira sobre a sociedade. Ao contrário, o conteúdo dessa vontade é também determinado pelas condições materiais da vida e, portanto, pela sua condição de classe detentora da propriedade privada e, enquanto tal, dominante. Aqui, cabe ressaltar que não é uma opção da burguesia expressar a sua vontade de classe enquanto direito ou não. Sob o modo de produção da vida baseado na propriedade privada, isso ocorre necessariamente. O direito, portanto, é inerente à sociedade capitalista e organicamente vinculado aos interesses da classe dominante.

\footnotetext{
"Os indivíduos que exercem o poder nestas condições [domínio da propriedade privada e da divisão do trabalho] não podem, portanto, abstraindo já do fato de o seu poder se dever constituir em Estado, fazer outra coisa senão dar à sua vontade determinada por estas condições precisas, a expressão geral de uma vontade de Estado, de uma lei - e o conteúdo dessa expressão é sempre dado pelas suas condições de classe, o que é possível deduzir com muita clareza do exame do direito privado e do direito penal" (Ideologia Alemã, v. II, p. 136).
}

No próximo capítulo, abordaremos com maior detalhe a crítica de Marx à vontade destacada de sua base real como fundamento do direito. Aqui, importa apenas a identificação do direito como expressão, não de uma vontade autônoma, mas sim de uma vontade bem específica, a vontade da classe dominante enquanto detentora da propriedade privada. Além disso, importa também enfatizar que essa forma de expressão da sua vontade enquanto lei, enquanto direito, não é uma contingência, mas uma necessidade intrínseca à sociedade capitalista.

Se o direito é produto da propriedade privada e tem como conteúdo os interesses da classe dominante, é evidente que para Marx o direito se fundamenta, não numa vontade autônoma, justa, livre e igual, que paira sobre a sociedade, mas sim na própria dominação de classe e, portanto, na força. Segundo Marx, o direito é sempre, em última análise, o direito do mais forte. 
"Na história real, os teóricos que têm tomado o poder como fundamento do direito opuseram-se diretamente àqueles que consideravam a vontade como base [...]. Se tornarmos o poder, a força, no fundamento do direito, tal como fizeram Hobbes e outros mais, então o direito, a lei, etc., apenas são o sintoma, a expressão de outras relações sobre que repousam o poder do Estado." (Ideologia Alemã, v. II, p. 135).

Essas outras relações são justamente as relações materiais de produção e, mais precisamente, todos os conflitos sociais que elas implicam em cada momento histórico. Vejamos alguns exemplos que ilustram nitidamente a força enquanto fundamento do direito.

Antes de tudo, para a garantia da propriedade privada, é imprescindível todo um aparato jurídico e repressivo. Desde logo, o "Estado de Direito", tão alardeado enquanto superação do direito da força, surge como uma forma de institucionalização do direito do mais forte, o que inclui não apenas a polícia, como também todo o aparato da justiça organizada. O "Estado de Direito", longe de ser a realização de uma justiça abstrata e universal, fundada na razão ou no pretenso acordo entre vontades livres e iguais, surge antes como a institucionalização do direito da burguesia enquanto classe mais forte, isto é, enquanto classe dominante. Nas palavras de Marx na Introdução de 1857:

"A noção que flutua no espírito dos economistas burgueses é que a polícia é mais favorável à produção que o direito da força, por exemplo. Esquecem apenas que o direito da força é também um direito, e que o direito do mais forte sobrevive ainda sob outra forma em seu "Estado de Direito'" (Introdução de 1857, p. 7).

Isso significa que não é a suposta equidade ou justiça de determinada lei que faz com ela domine, mas sim o fato de ela expressar uma determinada força social dominante. É a dominação social que garante a dominação da lei. A lei apenas é a expressão política, o sintoma, da dominação social. Sendo assim, uma lei só é capaz de vigorar na medida em que a força social que lhe fundamenta seja capaz de perpetuar sua dominação.

Na Nova Gazeta Renana, Marx analisa um caso emblemático sob este ponto de vista: a disputa entre a Coroa e Assembleia Nacional na Alemanha de 1848. Aqui, não nos importam os detalhes da situação história específica analisada por Marx, mas apenas seus contornos gerais. A certa altura, a Coroa vê a sua dominação política ameaçada por um outro poder político, a Assembleia Nacional, representante dos interesses da burguesia. Os 
debates passam a evocar o terreno do direito como o terreno da legitimidade que deve ser respeitada, em oposição ao terreno revolucionário. Para Marx, entretanto, essa situação foge à alçada do direito propriamente dito. Não se trata de aplicar o direito existente, uma vez que é precisamente a sua legitimidade que está sendo questionada por outro poder político. Trata-se, antes, de uma luta entre dois poderes políticos que, enquanto tal, só pode ser decidida pela força. No artigo 231, Marx é didático em sua explanação:

\begin{abstract}
"Em situações ordinárias, o poder público é o executor das leis existentes; criminoso é aquele que quebra essas leis ou que se opõe violentamente ao poder público no exercício delas. Em nosso caso, um dos poderes públicos quebrou a lei, o outro poder público, não importa qual, defendeu-a. A luta entre dois poderes políticos não diz respeito nem à esfera do direito privado nem à esfera do direito criminal. A questão sobre quem está com a razão, a coroa ou a Assembleia Nacional, é uma questão histórica. Todos os júris, todos os tribunais da Prússia, tomados em conjunto, não poderiam decidi-la. Só há um poder que a resolverá, a história. [...] se tratava aqui de uma luta entre dois poderes, e entre dois poderes só o poder pode decidir. [...] Agora não se trata mais do direito, e sim do poder [...] Poder contra poder. A vitória devia ser decidida entre ambos." (Nova Gazeta Renana, p. 461, n. 231).
\end{abstract}

Em outro artigo, Marx é ainda mais incisivo:

\begin{abstract}
"Dois soberanos! [...] Tão logo os dois soberanos não possam ou não queiram mais conciliar, transformam-se em dois soberanos inimigos. $\mathrm{O}$ rei tem o direito de atirar a luva à Assembleia, e a Assembleia tem o direito de atirar a luva ao rei. O maior direito está do lado do maior poder. O poder se comprova na luta. A luta se comprova na vitória. Ambos os poderes só podem fazer valer seu direito pela vitória, seu não-direito só pela derrota." (Nova Gazeta Renana, p. 262, n. 138).
\end{abstract}

Marx é categórico: o maior direito está do lado do maior poder. Trata-se, aliás, de um bordão que ecoa ao longo de toda a Nova Gazeta Renana: "O direito está do lado do poder" (Nova Gazeta Renana, p. 263, n. 138), "Quem tem o poder, tem o direito" (Nova Gazeta Renana, p. 288, n. 149), entre muitos outros casos. Como lembra Marx, a própria burguesia "alcançara o seu direito pela revolução" (Nova Gazeta Renana, p. 463, n. 231).

Esses casos de profunda transformação social evidenciam nitidamente a força enquanto fundamento do direito. Porém, mesmo em "situações ordinárias", ou seja, mesmo pressupondo o domínio consolidado da burguesia enquanto classe e, consequentemente, do 
direito burguês enquanto forma de regulação social, é possível ocorrer o mesmo impasse. Nesse caso, entretanto, a questão fica ainda mais clara, e mais interessante para nós, uma vez que se trata de um impasse interno ao próprio direito burguês, ou seja, ao direito baseado na lei da troca de mercadorias. Trata-se da luta entre a classe capitalista e a classe trabalhadora para a regulamentação da jornada de trabalho. Acompanhemos as palavras de Marx no Capital:

"O capitalista afirma seu direito, como comprador, quando procura prolongar o mais possível a jornada de trabalho e transformar, sempre que possível, um dia de trabalho em dois. Por outro lado, a natureza específica da mercadoria vendida impõe um limite ao consumo pelo comprador, e o trabalhador afirma seu direito, como vendedor, quando quer limitar a jornada de trabalho a determinada magnitude normal. Ocorre assim uma antinomia, direito contra direito, ambos baseados na lei da troca de mercadorias. Entre direitos iguais e opostos decide a força. Assim, a regulação da jornada de trabalho se apresenta, na história da produção capitalista, como luta pela limitação da jornada de trabalho, um embate que se trava entre a classe capitalista e a classe trabalhadora." (Capital, l, p. 265 , grifos meus).

A luta pela limitação da jornada de trabalho se configura também como uma "situação ordinária", no sentido de que se trata da sociedade capitalista consolidada e do seu funcionamento interno, com as suas próprias regras. Porém, aqui não se trata da quebra de uma lei, e portanto de um crime, mas sim da disputa entre dois direitos iguais. Do ponto de vista do direito, trata-se de uma troca de equivalentes como qualquer outra. Capitalista e trabalhador se confrontam em situação de igualdade na medida em que se apresentam como proprietários privados que querem trocar suas mercadorias. Ao capitalista, evidentemente, interessa prolongar ao máximo a jornada de trabalho, enquanto ao trabalhador, interessa limitá-la. Estes dois interesses opostos têm igual legitimidade do ponto de vista do próprio direito burguês. E nesse caso Marx é igualmente categórico: entre dois direitos iguais e opostos decide a força.

Não se trata aqui da força enquanto aplicação de uma lei, mas sim da força enquanto força social que fundamenta o direito. $O$ direito, enquanto expressão jurídica da propriedade privada, expressa igualmente os conflitos sociais que lhe são imanentes. O domínio da burguesia enquanto classe só é possível através da reiteração de seu poder e, portanto, através de um conflito permanente, em especial com a classe trabalhadora. 
Embora este não seja o nosso foco, a luta pela limitação da jornada de trabalho traz inevitavelmente a questão do papel do direito nas lutas da classe trabalhadora no interior da sociedade capitalista. Sobre isto, aqui cabe apenas enfatizar que a crítica de Marx à política e ao direito, embora revele seus limites intrínsecos, não implica de maneira alguma a recusa de toda e qualquer ação política imediata, e nem o desmerecimento de conquistas jurídicas pontuais. A luta prática se dá na particularidade de cada situação, e a própria atuação de Marx na Nova Gazeta Renana é um dos maiores exemplos disso, como bem exemplifica esta passagem:

\footnotetext{
"Não fazemos a utópica exigência de que seja proclamada a priori uma república alemã una e indivisível, mas exigimos do Partido Democrata Radical que não confunda o ponto de partida da luta e do movimento revolucionários com seu ponto de chegada. A unidade alemã, assim como a constituição alemã, só pode advir como resultado de um movimento no qual os conflitos internos e a guerra com o leste desempenharão papéis igualmente decisivos. A organização definitiva não pode ser decretada. Ela coincide com o movimento que temos de percorrer. Eis por que também não se trata de realizar esta ou aquela opinião, esta ou aquela ideia política; trata-se de entender o curso do desenvolvimento. A Assembleia Nacional tem apenas de dar os passos práticos possíveis no momento." (Nova Gazeta Renana, n. 7, p. 98-99).
}

A questão fundamental, para Marx, e para nós neste trabalho, é apenas não perder de vista a limitação intrínseca dessas conquistas. Em outras palavras, o reconhecimento da importância de conquistas específicas e imediatas não deve deixar-nos sucumbir à ilusão de que uma transformação jurídica seria suficiente para solucionar as contradições da sociedade capitalista ou conduzir a uma forma social superior. A ênfase aqui, portanto, recairá sempre sobre a vinculação orgânica do Estado e do direito com o capital e, consequentemente, sobre as limitações inerentes ao direito e à política no que se refere à realização da liberdade humana.

Sobre este aspecto, a crítica do direito realizada por Marx na Crítica do Programa de Gotha é incrivelmente esclarecedora. Mesmo supondo a realização do direito burguês sem contradições, ou seja, não somente na aparência, na esfera da circulação, mas também na esfera da produção; mesmo supondo a realização efetiva do direito igual, ainda assim subsistiriam limitações que the são imanentes. Mesmo supondo uma transformação 
significativa no conteúdo do direito, suas limitações se evidenciam nitidamente em sua própria forma.

\title{
1.2. A forma do direito: crítica da igualdade jurídica
}

\author{
“Já Platão teve a perspicácia necessária para \\ compreender que a lei tem de ser \\ necessariamente unilateral e fazer caso omisso da \\ individualidade" (Sagrada Família, p. 202).
}

A certa altura da Crítica ao Programa de Gotha, Marx se dedica a desmistificar as expressões direito igual e repartição equitativa, utilizados pelo programa. Em sua argumentação, Marx supõe uma forma social em que o direito igual e a repartição equitativa estivessem plenamente realizados. Trata-se de uma sociedade baseada na propriedade comum dos meios de produção, na qual todos os indivíduos são produtores. Uma vez abolida a propriedade privada, não existe mais a troca entre os produtos do trabalho. 0 trabalhador dá à sociedade uma determinada quantidade de trabalho e recebe a mesma quantidade de trabalho em produtos para o consumo.

\footnotetext{
"o produtor individual obtém da sociedade - depois de feitas as devidas deduções - precisamente aquilo que deu. $O$ que o produtor deu à sociedade constitui sua cota individual de trabalho. Assim, por exemplo, a jornada social de trabalho compõe-se da soma das horas de trabalho individual; o tempo individual de trabalho de cada produtor em separado é a parte da jornada social de trabalho com que ele contribui, é sua participação nela. A sociedade entrega-lhe um bônus consignando que prestou tal ou qual quantidade de trabalho (depois de descontar o que trabalhou para o fundo comum), e com este bônus ele retira dos depósitos sociais de meios de consumo a parte equivalente à quantidade de trabalho que prestou. A mesma quantidade de trabalho que deu à sociedade sob uma forma, recebe-a desta sob uma outra forma diferente." (Crítica de Gotha, p. 231).
}

Embora não exista mais a troca entre os produtos, a distribuição é realizada segundo a lei da troca de equivalentes, isto é, segundo o mesmo princípio que regula a troca de mercadorias. 


\begin{abstract}
"Aqui impera, evidentemente, o mesmo princípio que regula o intercâmbio de mercadorias, uma vez que este é um intercâmbio de equivalentes. Variaram a forma e o conteúdo, porque sob as novas condições ninguém pode dar senão seu trabalho, e porque, de outra parte, agora nada pode passar a ser propriedade do indivíduo, fora dos meios individuais de consumo. Mas, no que se refere à distribuição destes entre os diferentes produtores, impera o mesmo princípio que no intercâmbio de mercadorias equivalentes: troca-se uma quantidade de trabalho, sob uma forma, por outra quantidade igual de trabalho, sob outra forma diferente." (Crítica de Gotha, p. 231-232).
\end{abstract}

Entretanto, ao contrário do que ocorre na sociedade capitalista, a troca de equivalentes seria uma realidade. Nesse sentido, o direito igual seria a realização efetiva e sem contradições do princípio do direito burguês.

"Por isso, o direito igual continua sendo aqui, em princípio, o direito burguês, ainda que agora o princípio e a prática já não estejam mais em conflito, enquanto que no regime de intercâmbio de mercadorias, o intercâmbio de equivalentes não se verifica senão como termo médio, e não nos casos individuais." (Crítica de Gotha, p. 232).

Tomemos o direito burguês. Agora, imaginemos o princípio do direito burguês realizado plenamente e sem contradições. Pois bem, esta é precisamente a situação desenhada por Marx. E é justamente esta situação que evidencia os limites intrínsecos ao direito burguês. Acompanhemos a argumentação de Marx na íntegra:

\footnotetext{
"Apesar deste progresso, este direito igual continua trazendo implícita uma limitação burguesa. O direito dos produtores é proporcional ao trabalho que prestou; a igualdade, aqui, consiste em que é medida pelo mesmo critério: pelo trabalho.

"Mas, alguns indivíduos são superiores, física e intelectualmente, a outros e, pois, no mesmo tempo, prestam mais trabalho, ou podem trabalhar mais tempo; e o trabalho, para servir de medida, tem que ser determinado quanto à duração ou intensidade; de outro modo, deixa de ser uma medida. Este direito igual é um direito desigual para trabalho desigual. Não reconhece nenhuma distinção de classe, porque aqui cada indivíduo não é mais do que um operário como os demais; mas reconhece, tacitamente, como outros tantos privilégios naturais, as desiguais aptidões dos indivíduos, e, por conseguinte, a desigual capacidade de rendimento. No fundo é, portanto, como todo direito, o direito da desigualdade. 0 direito só pode consistir, por natureza, na aplicação de uma medida igual; mas os indivíduos desiguais (e não seriam indivíduos diferentes se não fossem desiguais) só podem ser medidos por uma mesma medida sempre e quando sejam considerados sob um ponto de vista igual, sempre e quando sejam olhados apenas sob um aspecto determinado: por exemplo, no caso
} 
concreto, só como operários, e não se veja neles nenhuma outra coisa, isto é, prescinda-se de tudo o mais. Prossigamos: uns operários são casados e outros não, uns têm mais filhos que outros, etc., etc. Para igual trabalho e, por conseguinte, para igual participação no fundo social de consumo, uns obtêm de fato mais do que outros, uns são mais ricos do que outros, etc. Para evitar todos estes inconvenientes, o direito não teria que ser igual, mas desigual. (Crítica de Gotha, p. 232).

Marx é enfático: este direito igual é um direito desigual para trabalho desigual; no fundo é, portanto, como todo direito, o direito da desigualdade. Isso significa que a igualdade, fundamento do direito burguês, ainda que supondo a sua realização sem contradições, produz necessariamente desigualdade.

A natureza do direito, segundo Marx, é a aplicação de uma medida igual e, portanto, a consideração dos indivíduos apenas sob um aspecto determinado, justamente para permitir a equiparação. Assim, necessariamente, todos os demais aspectos que diferenciam os indivíduos são desconsiderados. Nessa situação hipotética, os indivíduos seriam considerados apenas enquanto trabalhadores e seu trabalho medido de acordo com o tempo ou a intensidade. Porém, como observa Marx, os indivíduos são diferentes entre si, no que se refere tanto às suas capacidades quanto às suas necessidades. No que se refere às capacidades, uns são mais fortes, outros mais fracos, uns mais inteligentes, outros menos, e portanto uns podem prestar mais trabalho no mesmo tempo, ou podem trabalhar durante mais tempo do que outros. No que se refere às necessidades, por exemplo, uns são casados, outros não, uns têm filhos, outros não, uns têm mais que outros etc. Isso significa que, mesmo a igualdade jurídica sendo realizada sem contradições, o seu resultado seria necessariamente remunerações desiguais para trabalhos desiguais.

Segundo Marx, essa limitação faz parte da natureza do direito, é intrínseca a ele, e portanto é incorrigível. Como ele afirma, "este direito igual é, como todo o direito, o direito da desigualdade". Não existe em Marx uma proposta de transformação do direito que poderia torná-lo justo. Para Marx, o direito é injusto por natureza. A única afirmação que ele faz nesse sentido carrega uma profunda ironia: "para evitar todos estes inconvenientes, o direito não teria que ser igual, mas desigual". Isso significa que a verdadeira igualdade, para Marx, só seria possível levando em conta as desigualdades reais entre os indivíduos. Mas, se o direito levasse em conta as desigualdades, ou seja, se fosse desigual, deixaria de ser 
direito. Nesse sentido, a crítica do direito burguês é ao mesmo a crítica do direito enquanto tal.

Entretanto, Marx esclarece que essas limitações do direito burguês seriam inevitáveis na "primeira fase da sociedade comunista, tal como brota da sociedade capitalista, depois de um longo e doloroso parto" (Crítica de Gotha, p. 233). Isso porque

\begin{abstract}
"Do que se trata aqui não é de uma sociedade comunista que se desenvolveu sobre sua própria base, mas de uma que acaba de sair precisamente da sociedade capitalista e que, portanto, apresenta ainda em todos os seus aspectos, no econômico, moral e no intelectual, o selo da velha sociedade de cujas entranhas procede." (Crítica de Gotha, p. 231).
\end{abstract}

Somente na fase superior da sociedade comunista é que seria possível a superação completa do direito enquanto tal e, consequentemente, a realização da igualdade verdadeira, a partir da consideração das desigualdades reais entre os indivíduos, tanto no que se refere às suas capacidades quanto às suas necessidades, tal como sintetizado no lema: de cada um conforme suas capacidades; a cada um conforme duas necessidades. Nas palavras de Marx:

"Na fase superior da sociedade comunista, quando houver desaparecido a subordinação escravizadora dos indivíduos à divisão do trabalho e, com ela, o contraste entre o trabalho intelectual e o trabalho manual; quando o trabalho não for somente um meio de vida, mas a primeira necessidade vital; quando, com o desenvolvimento dos indivíduos em todos os seus aspectos, crescerem também as forças produtivas e jorrarem em caudais os mananciais da riqueza coletiva, só então será possível ultrapassar-se totalmente o estreito horizonte do direito burguês e a sociedade poderá inscrever em suas bandeiras: De cada qual, segundo sua capacidade; a cada qual, segundo suas necessidades." (Crítica de Gotha, p. 232-233). 


\title{
2. Crítica dos direitos humanos
}

\subsection{Direitos humanos como direitos da livre concorrência}

A Questão Judaica é reconhecidamente o texto de Marx em que o tema dos direitos do homem aparece de maneira mais desenvolvida. A certa altura do primeiro artigo, Marx convida o leitor a acompanhá-lo em sua análise:

\begin{abstract}
"Consideremos por um momento os chamados direitos do homem; examinemo-los na sua forma autêntica, na forma que possuem entre aqueles que os descobriram, os Norte-Americanos e os Franceses! Os direitos do homem são, em parte, direitos políticos, que só podem exercerse quando se é membro de uma comunidade. O seu conteúdo é a participação na vida da comunidade, na vida política da comunidade, na vida do Estado. Integram-se na categoria de liberdade política, de direitos civis, que, como vimos, não pressupõem de nenhum modo a abolição consistente e positiva da religião; nem por conseguinte do judaísmo. Fica ainda por considerar a outra parte, a saber, os droits de l'homme enquanto distintos dos droits du citoyen" (Questão Judaica, p. 54-55).
\end{abstract}

Antes de tudo, é preciso ressaltar que Marx considera os direitos do homem não segundo qualquer teoria ou ideal pré-estabelecido de caráter filosófico, moral ou jurídico, mas em sua "forma autêntica", ou seja, tal como foram expressos pelos seus "descobridores" nas Declarações de Direitos e nas Constituições norte-americanas e francesas do século XVIII ${ }^{25}$.

Tomando-as como base, Marx constata que os direitos do homem têm duas ramificações: 1) os direitos do homem enquanto cidadão, ou seja, os direitos políticos, que dizem respeito à participação na vida da comunidade, do Estado, e 2) os direitos do homem enquanto distintos dos direitos do cidadão, estes os "chamados direitos do homem". A análise dos direitos do homem enquanto cidadão foi o que Marx desenvolveu desde o início da Questão Judaica até este ponto e é o que constitui o núcleo de sua crítica da emancipação política, o que foi abordado no segundo capítulo desta tese. A análise dos direitos do homem enquanto distintos dos direitos do cidadão, ou seja, dos "chamados

\footnotetext{
${ }^{25}$ Em sua análise, Marx cita as Declarações francesas de 1791 e 1793, as Constituições francesas de 1791, 1793 e 1795, e também as Constituições da Pensilvânia e do New Hampshire.
} 
direitos do homem", é o que vai ocupar Marx deste ponto do texto até o final do primeiro artigo.

Como vimos no capítulo anterior, no primeiro passo crítico da Questão Judaica Marx começa expondo a posição de Bauer segundo a qual o judeu, e o homem em geral, só poderia emancipar-se como cidadão se abandonasse o judaísmo, e a religião em geral, valendo-se de diversas citações do texto de seu oponente. Logo em seguida, apoiado em historiadores da América do Norte da época, Marx traz à tona o fato de que os Estados Unidos eram, ao mesmo tempo, o país da religiosidade e o país da plena emancipação política. É a partir deste simples fato - que por si basta para desmontar toda a argumentação de Bauer - que Marx desenvolve a "crítica da própria emancipação política" (Questão Judaica, p. 39), cujos principais momentos foram analisados acima.

No caso específico dos direitos humanos, verificamos o mesmo procedimento. Primeiro, através de várias citações, Marx expõe a posição de Bauer segundo a qual os judeus só poderiam adquirir os "direitos universais do homem" sob a condição de abandonarem sua religião, condição que seria válida também para os cristãos. Nas palavras de Marx: "Segundo Bauer, o homem vê-se forçado a sacrificar o 'privilégio da fé' a fim de adquirir os direitos gerais do homem" (Questão Judaica, p. 54). E, num segundo momento, inicia o ataque citando, de cada uma das Declarações e Constituições, os artigos que estabelecem a liberdade religiosa como um direito do homem - Marx cita a Declaração de 1791, a Constituição de 1791, a Declaração de 1793, a Constituição de 1795, a Constituição da Pensilvânia e a Constituição do New Hampshire. Isso Ihe permite concluir, em frontal oposição a Bauer, que

"Entre eles [os direitos do homem], encontra-se a liberdade de consciência, o direito de praticar a religião que se escolher. o privilégio da fé é expressamente reconhecido, ou como um direito do homem, ou como consequência de um direito do homem, isto é, a liberdade" (Questão Judaica, p. 55).

Ou, em outras palavras, mais incisivas:

"A incompatibilidade entre a religião e os direitos do homem encontra-se tão pouco manifesta no conceito dos direitos do homem que o direito de 
ser religioso, segundo o costume de cada qual, e de praticar o culto da sua religião particular, vem expressamente entre eles incluído. 0 privilégio da fé é um direito universal do homem" (Questão Judaica, p. 55-56).

Só depois desse xeque-mate em Bauer é que Marx se volta à análise específica dos direitos do homem enquanto distintos dos direitos do cidadão, isto é, dos chamados direitos do homem. Vimos que Marx considera os direitos do homem não segundo um ideal préestabelecido, e sim segundo a sua "forma autêntica", ou seja, da maneira como vêm expressos nas Declarações e Constituições redigidas por seus descobridores, os norteamericanos e os franceses. Mas quais são, afinal, estes direitos? Para identificá-los, Marx evoca a "constituição mais radical", ou seja, a Constituição francesa de 1793, o que já indica a dimensão do alvo de sua crítica. Segundo esta Constituição, os direitos do homem são: liberdade, propriedade, igualdade e segurança. Marx começa por citar os artigos que enunciam cada um dos direitos para em seguida apresentar sua análise crítica. Acompanhemos a argumentação de Marx, começando pela enunciação do direito à liberdade:

"A liberdade é o poder que o homem tem de fazer tudo o que não prejudique os direitos dos outros'” (Constituição de 1793, Art. 6 in Questão Judaica, p. 56).

Depois da enunciação, a análise:

\begin{abstract}
"Por conseguinte, a liberdade é o direito de fazer tudo o que não cause dano aos outros. Os limites dentro dos quais cada um pode atuar sem prejudicar os outros são determinados pela lei, assim como a fronteira entre dois campos é assinalada por uma estaca. Trata-se da liberdade do homem enquanto mônada isolada, retirado para o interior de si mesmo. [...] a liberdade como direito do homem não se funda nas relações entre homem e homem, mas antes na separação do homem a respeito do homem. É o direito de tal separação, o direito do indivíduo circunscrito, fechado em si mesmo" (Questão Judaica, p. 56-57).
\end{abstract}

Já aqui fica patente que Marx não parte do direito à liberdade como um postulado jurídico, filosófico ou moral de caráter universal, pretensamente auto-evidente. Ao contrário, parte da enunciação real deste direito e o denuncia, não por se referir ao indivíduo em geral, e sim por se referir a este indivíduo, isto é, ao indivíduo "circunscrito, 
fechado em si mesmo", ao "homem enquanto mônada isolada, retirado para o interior de si mesmo", ou seja, ao homem separado da comunidade e em oposição aos outros homens. É evidente no texto que a crítica de Marx não se volta contra a liberdade pessoal em geral, mas apenas contra "esta liberdade pessoal", na medida em que "Leva cada homem a ver nos outros homens, não a realização, mas a limitação da sua própria liberdade" (Questão Judaica, p. 57).

Continuemos a análise com a enunciação do direito à propriedade:

"'O direito da propriedade é o que pertence a cada cidadão de desfrutar e de dispor como quiser dos seus bens e rendimentos, dos frutos do próprio trabalho e diligência'"' (Constituição de 1793, Art. 16, in Questão Judaica, p. 57).

Segundo Marx,

"O direito humano da propriedade privada, portanto, é o direito de fruir da própria fortuna e de dela dispor como se quiser, sem atenção pelos outros homens, independentemente da sociedade. É o direito do interesse pessoal" (Questão Judaica, p. 57).

O interesse pessoal, egoísta, é elevado à categoria de direito do homem. Tanto no caso do direito à liberdade como no do direito à propriedade, Marx denuncia o fato de o homem ser considerado enquanto homem egoísta, ou seja, enquanto indivíduo circunscrito, separado da comunidade e oposto aos outros homens. Mas, além disso, Marx revela uma íntima conexão entre os direitos de liberdade e de propriedade, demonstrando que não foi à toa a sua comparação da lei, enquanto delimitadora da esfera de liberdade dos indivíduos, com a estaca que demarca a fronteira entre dois campos. Segundo ele,

\footnotetext{
"A aplicação prática do direito humano de liberdade é o direito da propriedade privada. [...] Esta liberdade individual e a respectiva aplicação formam a base da sociedade civil. Leva cada homem a ver nos outros homens, não a realização, mas a limitação da sua própria liberdade" (Questão Judaica, p. 57).
}

Segundo Marx, o direito de propriedade privada é a aplicação prática do direito de liberdade. Como podemos ver, Marx não aponta nenhuma contradição entre a liberdade e a propriedade enquanto direitos do homem e, por isso, não se vê obrigado a exigir a limitação 
de uma para a garantia da outra, como ocorre na tradição filosófica liberal. Pelo contrário, a liberdade e a propriedade são aqui denunciadas em conjunto como dois lados de uma mesma moeda, precisamente pelo fato de se referirem ao homem enquanto separado da comunidade, fechado em si mesmo e em oposição aos outros homens. A liberdade e a propriedade, tal como enunciadas nas Declarações, estão para Marx em tanta harmonia entre si, que uma é apresentada como o princípio e a outra como sua aplicação prática.

Ao identificar a liberdade e a propriedade privada como a base da sociedade civil, a crítica de Marx aos direitos do homem se volta explicitamente para os pressupostos do Estado político. Assim, depois de explicar os constrangimentos religiosos a partir dos constrangimentos profanos, Marx começa agora a explicar os constrangimentos políticos a partir dos constrangimentos sociais - depois de transformar a crítica da religião na crítica da política, começa agora a transformar a crítica da política na crítica da sociedade civil. Isso mostra que a crítica dos direitos do homem é ao mesmo tempo o início da crítica da sociedade civil.

Prossigamos com a enunciação do direito à igualdade:

\footnotetext{
"'A igualdade consiste no fato de que a lei é igual para todos, quer ela proteja ou puna'" (Constituição de 1795, Art. 3, in Questão Judaica, p. 57).
}

Segundo Marx

\footnotetext{
"A igualdade não possui aqui significado político. É apenas o igual direito à liberdade como antes foi definido; a saber, todo homem é igualmente considerado como mônada auto-suficiente" (Questão Judaica, p. 57).
}

Quando Marx afirma que "A igualdade não possui aqui significado político", quer dizer que ela não se refere ao homem enquanto membro da comunidade política, do Estado, mas ao homem enquanto membro da sociedade civil, ou seja, ao homem egoísta, fechado em si mesmo, separado da comunidade e oposto aos outros homens. Por isso, se o direito de propriedade é a aplicação prática do direito de liberdade, podemos dizer que o direito de igualdade é a generalização do direito de liberdade: segundo Marx, a igualdade enquanto direito do homem significa apenas que "todo homem é igualmente considerado como mônada auto-suficiente". 
Como vemos, em sua crítica dos chamados direitos do homem, Marx não denuncia a igualdade por seu caráter formal ou abstrato, ou seja, por estar em contradição com uma flagrante desigualdade concreta; e nem propõe realizar efetivamente essa igualdade, abolindo a desigualdade real. Como vimos no segundo capítulo, ao afirmar que o Estado só pode proclamar "que todo membro do povo é igual parceiro na soberania popular" (Questão Judaica, p. 44) por cima das diferenças efetivas e ao mostrar que no Estado o homem "é despojado de sua vida real individual, e dotado de universalidade irreal" (Questão Judaica, p. 46), Marx de fato denuncia o caráter abstrato ou formal da igualdade; mas, naquele contexto, Marx se referia à igualdade enquanto direito do cidadão, ou seja, à igualdade entre os homens enquanto membros da comunidade política, do Estado, e não à igualdade enquanto direito do homem.

Por fim, acompanhemos a enunciação do direito à segurança:

\begin{abstract}
"A segurança consiste na proteção concedida pela sociedade a cada um dos seus membros para a preservação da sua pessoa, dos seus direitos e da sua propriedade" (Constituição de 1793, Art. 18, in Questão Judaica, p. 57).
\end{abstract}

Segundo Marx,

\begin{abstract}
"A segurança constitui o supremo conceito social da sociedade civil, o conceito da polícia. Toda sociedade existe unicamente para garantir a cada um dos seus membros a preservação de sua pessoa, dos direitos e da sua propriedade. [...] $O$ conceito de segurança não chega para elevar a sociedade civil acima do próprio egoísmo. A segurança surge antes como a garantia do seu egoísmo" (Questão Judaica, p. 58).
\end{abstract}

A segurança enquanto direito do homem vem para garantir a liberdade, a propriedade e a igualdade tal como foram formuladas anteriormente. Ou seja, vem para garantir a existência do homem egoísta, separado e oposto aos outros homens. Sendo assim, a segurança não vem para elevar a sociedade civil acima do próprio egoísmo, mas sim para garantir o seu egoísmo.

Após a análise específica de cada um dos "chamados direitos do homem", tais como enunciados pelos seus descobridores, Marx chega à seguinte conclusão: 


\begin{abstract}
"Assim, nenhum dos supostos direitos do homem vai além do homem egoísta, do homem enquanto membro da sociedade civil; quer dizer, enquanto indivíduo separado da comunidade, confinado a si próprio, aos seus interesses privados e ao seu capricho pessoal. O homem está longe de ser considerado, nos direitos do homem, como um ser genérico; pelo contrário, a própria vida genérica - a sociedade - surge como sistema que é externo ao indivíduo, como limitação da sua independência original. 0 único laço que os une é a necessidade natural, a carência e o interesse privado, a preservação da sua propriedade e das suas pessoas egoístas" (Questão Judaica, p. 58).
\end{abstract}

Segundo Marx, os direitos do homem são de fato "os direitos do homem egoísta". Porém, como fica evidente nas passagens citadas, Marx se refere ao homem egoísta no sentido do "indivíduo separado da comunidade, confinado a si próprio, aos seus interesses privados e ao seu capricho pessoal", ou seja, do "homem separado dos outros homens e da comunidade" (Questão Judaica, p. 58). Assim, os direitos do homem são, para Marx, os direitos do homem egoísta no mesmo sentido em que são os direitos do burguês - isto é, do bourgeois distinto do citoyen -, pois as duas expressões designam igualmente o membro da sociedade civil, ou seja, o indivíduo efetivamente separado da comunidade, efetivamente isolado dos outros homens pela oposição real entre os interesses particulares. ${ }^{26}$

Por conseguinte, nas declarações o homem não é visto como ser genérico, isto é, como ser comunitário, em relação com os outros homens. Como vimos, Marx demonstra que a relação com os outros surge como limitação, e não realização, da liberdade do indivíduo. Isso significa que a própria vida genérica - isto é, a sociedade - surge, nos direitos do homem, como algo externo e oposto ao indivíduo. Para Marx, os direitos do homem se apresentam como a tradução conceitual da sociedade civil e de seus elementos, inclusive no que se refere ao seu conflito com a vida genérica.

Como vimos no Capítulo 2, se a revolução política (no caso a Revolução Francesa de 1789) significou a remoção do jugo político feudal, é preciso notar que ela significou ao mesmo tempo a remoção dos laços que acorrentavam o espírito egoísta da sociedade civil. Segundo Marx, a revolução política fez com que os elementos particulares da vida civil não

\footnotetext{
${ }^{26}$ Como vemos, nem o termo "egoísta" é utilizado exclusivamente no sentido moral, e nem o termo "burguês" é utilizado no sentido de membro da classe burguesa. Ao longo de toda a Questão Judaica, aliás, não há nenhuma referência a classes sociais, e o termo "burguês" designa invariavelmente o bourgeois distinto do citoyen, ou seja, o membro da sociedade civil em oposição ao membro do Estado político.
} 
tivessem mais caráter político, ou seja, não determinassem mais a relação do indivíduo singular com o Estado como totalidade. Mas ela só consegue isso através da separação entre os indivíduos, de um lado, e seu conteúdo vital, de outro.

Sendo assim, a revolução política que dissolve a sociedade feudal não liberta o indivíduo dos elementos alienados que formavam o conteúdo de sua vida civil (constrangimentos seculares), mas, ao contrário, apenas põe esses elementos em liberdade, ou seja, permite que se movimentem freneticamente. A liberdade alcançada, segundo Marx, é portanto a liberdade daquele homem, que constituía o fundamento da sociedade feudal, o homem egoísta, isto é, o homem separado dos outros homens e da comunidade.

E os direitos do homem, de acordo com Marx, surgem justamente como a expressão teórica dessa transformação prática, como o reconhecimento, por parte do Estado, de sua base real, isto é, da sociedade civil e de seus elementos alienados. Acompanhemos as palavras de Marx:

\footnotetext{
"A sociedade feudal foi dissolvida no seu elemento básico, o homem; mas no homem que constituía o seu real fundamento, no homem egoísta.

"Este homem, o membro da sociedade civil, é agora a base e o pressuposto do Estado político. Como tal é reconhecido nos direitos do homem.

"Mas a liberdade do homem egoísta e o reconhecimento desta liberdade surge mais exatamente como o reconhecimento do movimento frenético dos elementos culturais e materiais, que formam o conteúdo da sua vida.

"Assim o homem não se libertou da religião; recebeu a liberdade religiosa. Não ficou liberto da propriedade; recebeu a liberdade da propriedade. Não foi libertado do egoísmo do comércio; recebeu a liberdade para se empenhar no comércio" (Questão Judaica, p. 61).
}

Nesta passagem, fica evidente a imbricação entre a crítica aos direitos do homem e a crítica da emancipação política. Marx está explicitando a gênese do Estado político através da análise da revolução política e é neste contexto que sua crítica aos direitos do homem atinge a maior intensidade. Os direitos do homem surgem como o reconhecimento da base real do Estado político, isto é, do espírito egoísta da sociedade civil. Ou, mais ainda, como o reconhecimento da liberdade dos elementos alienados da vida civil; não da liberdade do indivíduo, mas apenas da liberdade do indivíduo burguês, isto é, do membro da sociedade civil, do homem egoísta. A emancipação política e, com ela, os direitos do homem vêm para 
dar liberdade aos elementos alienados de sua vida, que agora podem se movimentar freneticamente, seguir sua própria lógica, sem entraves políticos.

Essa conclusão é quase literalmente repetida na Sagrada Família, na retomada da polêmica com Bauer sobre a Questão Judaica. Depois de reafirmar os principais aspectos de sua crítica da emancipação política, Marx ironiza a identificação feita por Bruno Bauer entre a proclamação dos direitos do homem e o reconhecimento da "humanidade livre", como se os direitos do homem instituíssem a liberdade humana, remetendo o leitor ao primeiro artigo de sua Questão Judaica. Os direitos do homem surgem novamente como os direitos do indivíduo burguês egoísta e a liberdade, não como a liberdade dos indivíduos, mas sim como a liberdade dos elementos materiais e espirituais da sua vida civil, que agora, livres do privilégio, podem se movimentar freneticamente. Os direitos do homem, portanto, não têm como finalidade a superação, mas sim a garantia e a manutenção das limitações da vida civil atual. Diz Marx:

\begin{abstract}
"Reconhecimento da humanidade livre? A 'humanidade livre', cujo reconhecimento os judeus não pensavam ambicionar, mas de fato ambicionavam, é a mesma 'humanidade livre' que encontrou seu reconhecimento clássico nos assim chamados direitos gerais do homem. [...] “Nos 'Anais franco-alemães' desenvolveu-se para o senhor Bauer a prova de que essa 'humanidade livre' e seu 'reconhecimento' não são nada mais do que o reconhecimento do indivíduo burguês egoísta e do movimento desenfreado dos elementos materiais e espirituais que formam o conteúdo de sua situação de vida, o conteúdo da vida burguesa atual; que, portanto, os direitos humanos não liberam o homem da religião, mas apenas lhe outorgam a liberdade religiosa, não o liberam da propriedade, mas apenas Ihe conferem a liberdade da propriedade, não o liberam da sujeira do lucro, mas, muito antes, Ihe outorgam a liberdade para lucrar" (Sagrada Família, p. 131-132).
\end{abstract}

Mais adiante, ecoando nitidamente as Glosas de 1844, Marx apresenta essa ideia de uma maneira ainda mais incisiva, ao comparar o reconhecimento dos direitos humanos pelo Estado moderno com o reconhecimento da escravatura pelo Estado antigo. Vale acompanhar a passagem na íntegra:

"Demonstrou-se como o reconhecimento dos direitos humanos por parte do Estado moderno tem o mesmo sentido que o reconhecimento da escravatura pelo Estado antigo. Com efeito, assim como o Estado antigo 
tinha como fundamento natural a escravidão, o Estado moderno tem como base natural a sociedade burguesa e o homem da sociedade burguesa, quer dizer, o homem independente, entrelaçado com o homem apenas pelo vínculo do interesse privado e da necessidade natural inconsciente, o escravo do trabalho lucrativo e da necessidade egoísta, tanto da própria quanto da alheia. O Estado moderno reconhece essa sua base natural, enquanto tal, nos direitos gerais do homem. Mas não os criou. Sendo como é, o produto da sociedade burguesa, impulsionada por seu próprio desenvolvimento até mais além dos velhos vínculos políticos, ele mesmo reconhece, por sua vez, seu próprio local de nascimento e sua própria base mediante a proclamação dos direitos humanos. Portanto, a emancipação política dos judeus e a concessão a estes dos 'direitos humanos' constitui um ato mutuamente condicionante" (Sagrada Família, p. 132).

Nesta passagem, fica evidente que a crítica dos direitos do homem é ao mesmo tempo a crítica da sociedade civil. Os direitos do homem surgem, não como a instauração e a garantia da liberdade humana real, mas antes como o reconhecimento e a garantia da escravidão da sociedade civil e, portanto, como o reconhecimento, por parte do Estado moderno, do seu próprio local de nascimento e de sua própria base.

\subsection{A ilusão de ótica dos revolucionários franceses}

A certa altura de sua crítica dos direitos do homem, Marx apresenta um "enigma", algo "incompreensível", "uma ilusão de ótica" da "consciência dos libertadores políticos"27. Acompanhemos Marx desde a formulação do enigma:

"É já enigmático que uma nação, que começara precisamente a libertar-se, a eliminar todas as barreiras entre as diferentes seções da população e a estabelecer uma comunidade política, tenha de proclamar solenemente (Declaração de 1791) os direitos do homem egoísta, separado dos outros homens e da comunidade, e tenha de renovar semelhante proclamação num momento em que só a mais heroica dedicação pode salvar a nação (e, por conseguinte, a isso é chamada com urgência), num momento em que o sacrifício de todos os interesses da sociedade civil é elevado a ordem do dia e o egoísmo deve ser castigado como crime (Declaração dos Direitos do Homem, etc., 1793)" (Questão Judaica, p. 58).

\footnotetext{
${ }^{27}$ Quando Marx se refere à "consciência dos libertadores políticos", é evidente que está se dirigindo às Declarações e Constituições, na medida em que elas são o modo como os revolucionários efetivamente expressaram o seu pensamento, a sua consciência.
} 
E continua:

"O assunto torna-se ainda mais incompreensível ao observarmos que os libertadores políticos reduzem a cidadania, a comunidade política, a simples meio para preservar os chamados direitos do homem; e que, por consequência, o citoyen é declarado como servo do 'homem' egoísta, a esfera em que o homem age como ser genérico vem degradada para a esfera onde ele atua como ser parcial; e que, por fim, é o homem como bourgeois e não o homem como citoyen que é considerado como o homem verdadeiro e autêntico" (Questão Judaica, p. 58-59).

Marx cita as declarações, que corroboram sua afirmação:

"'O objetivo de toda associação política é a preservação dos direitos naturais e imprescritíveis do homem' (Declaração dos Direitos do Homem, etc. 1791, Artigo 2). 'O governo é instituído a fim de garantir ao homem o desfrutar dos seus direitos naturais e imprescritíveis' (Declaração, etc., 1793, Artigo 1)'" (Questão Judaica, p. 59).

E conclui:

"Desse modo, mesmo no período do seu entusiasmo juvenil, que atingiu o clímax pela força das circunstâncias, a vida política se declara como simples meio, cuja finalidade é a vida da sociedade civil" (Questão Judaica, p. 59).

Como vimos, Marx se refere a esse enigma como uma ilusão de ótica da consciência dos revolucionários, ou seja, um enigma psicológico e teórico, na medida em que está presente, não na sua ação direta, na sua prática (que aliás contradiz a sua teoria), mas sim nas declarações e constituições elaboradas por eles, as quais expressam a sua compreensão da realidade. Nas palavras de Marx:

"por que será que, na consciência dos libertadores políticos, a relação se encontra invertida e o fim aparece como meio e o meio como fim?" (Questão Judaica, p. 59).

De acordo com Marx, a ilusão de ótica da consciência dos revolucionários consiste, primeiro, em considerar o membro da sociedade civil, isto é, o homem egoísta, isolado e oposto aos demais, como o homem natural, e os seus direitos como direitos naturais, inatos, e, segundo, em considerar este homem como o homem verdadeiro e autêntico. Essa ilusão 
de ótica está intimamente associada às questões que Marx colocou logo no início de sua análise dos direitos do homem:

\begin{abstract}
"Por que é que ao membro da sociedade civil lhe chamam 'homem', simplesmente homem, e por que é que os seus direitos recebem o nome de 'direitos do homem'? Como se explicará semelhante fato? Pela relação entre o Estado político e a sociedade civil e pela natureza da emancipação política" (Questão Judaica, p. 56).
\end{abstract}

A breve indicação de resposta já fornece vários elementos: pela relação entre $o$ Estado e a sociedade civil e pela natureza da emancipação política. Marx nos remete ao fato de que a sociedade civil é base do Estado, contém seus pressupostos, e de que o Estado só existe sobre essa base, bem como ao fato de que a emancipação política abole idealmente as particularidades, mas na realidade as pressupõe e as deixa atuar enquanto tais.

Depois da análise da revolução política, Marx é categórico em sua resposta:

"A revolução política dissolve a sociedade civil nas suas componentes sem revolucionar estas componentes e as submeter à crítica. Esta revolução considera a sociedade civil, o mundo das necessidades, o trabalho, os interesses privados e a lei civil como a base da sua própria existência, como um pressuposto inteiramente subsistente, portanto, como a sua base natural" (Questão Judaica, p 62).

Sendo assim,

"O homem, como membro da sociedade civil - o homem apolítico -, surge necessariamente como o homem natural", uma vez que "O homem egoísta é o resultado passivo, apenas dado, da dissolução da sociedade, objeto de certeza imediata e, consequentemente, um objeto natural" (Questão Judaica, p. 62).

Quanto aos direitos do homem, por sua vez, Marx explica:

"Os droits de l'homme aparecem como droit naturels, porque a atividade autoconsciente se concentra na ação política" (Questão Judaica, p. 62).

Marx demonstra que a revolução política dissolve os elementos da sociedade feudal sem revolucioná-los e, além disso, tomando-os como seu pressuposto, como sua base 
natural. É assim que a revolução política se efetiva. E é precisamente essa maneira de se efetivar que gera a ilusão de ótica dos revolucionários. Pois, exatamente por se concentrarem na ação política, os próprios revolucionários acabam tomando a sociedade civil e seus elementos como algo apenas dado, como um pressuposto inteiramente subsistente, como uma base natural. Sendo assim, o homem egoísta só poderia aparecer como homem natural e os direitos do homem só poderiam aparecer como direitos naturais e inatos.

Isso soluciona o primeiro aspecto do enigma. Resta ainda explicar por que "é o homem como bourgeois e não o homem como citoyen que é considerado como o homem verdadeiro e autêntico". Diz Marx:

"Por fim, o homem como membro da sociedade civil é identificado como o homem autêntico, o homme como distinto do citoyen, porque é o homem na sua existência sensível, individual e imediata, ao passo que o homem político é unicamente o homem abstrato, artificial, o homem como pessoa alegórica, moral. Deste modo, o homem tal como é na realidade reconhece-se apenas na forma do homem egoísta, e o homem verdadeiro, unicamente na forma do citoyen abstrato" (Questão Judaica, p. 62).

\subsection{Contradição entre teoria e prática dos direitos do homem}

Marx constata que, no período revolucionário, há uma flagrante contradição entre a teoria e a prática dos direitos do homem. Se na teoria, para os revolucionários, a vida política serve como simples meio para garantir os direitos do homem, na prática, esses direitos são suprimidos assim que entram em conflito com a vida política. Nas palavras de Marx:

\footnotetext{
"Sem dúvida, a sua prática revolucionária encontra-se em flagrante contradição com a teoria. Por exemplo, enquanto a segurança é proclamada como um dos direitos do homem, a violação da intimidade da correspondência estava abertamente na ordem do dia. Enquanto a 'ilimitada liberdade de imprensa' (Constituição de 1793, Artigo 122), como corolário do direito do homem, da liberdade individual, é garantida, a liberdade de imprensa é inteiramente destruída, uma vez que a liberdade de imprensa não deve ser permitida quando compromete a liberdade
} 
pública'. Equivale isto a dizer: o direito humano à liberdade deixa de ser um direito a partir do momento em que entra em conflito com a vida política, enquanto, na teoria, a vida política é apenas a garantia dos direitos do homem, dos direitos do homem individual e deve, portanto, suspender-se logo que entre em contradição com o seu objetivo, os direitos do homem" (Questão Judaica, p. 59)

Esta é a única passagem da Questão Judaica em que Marx aponta uma contradição entre a teoria e a prática dos direitos do homem. Ainda assim, é preciso enfatizar que a teoria a que se refere Marx é a enunciação desses direitos conforme as Declarações e Constituições, e a prática é a prática dos revolucionários franceses, especialmente no momento mais dramático da revolução ${ }^{28}$.

Os exemplos anteriores de Marx sobre a violação da intimidade e da liberdade de imprensa descrevem um desses momentos "em que a autolibertação humana procura realizar-se sob a forma da emancipação política" ou, mais especificamente, em que "a vida política procura abafar os próprios pressupostos - a sociedade civil e seus elementos - e estabelecer-se como a genuína e harmoniosa vida genérica do homem". Nesses momentos, a prática revolucionária, em contradição com a teoria, afirma a vida política como o objetivo e a vida da sociedade civil apenas como o meio. A liberdade pública é colocada, na prática, como objetivo supremo, que acaba justificando a supressão dos direitos individuais solenemente proclamados.

Porém, se é verdade que Marx se refere a uma contradição entre a teoria e a prática dos direitos do homem, é preciso enfatizar que essa contradição é apenas de um momento histórico particular, identificado aqui como o período mais dramático da revolução francesa, o qual, aliás, não é a regra, e sim a exceção (nas próprias palavras de Marx).

Além do mais, ao retomar a questão judaica na Sagrada Família, Marx é enfático ao afirmar que após esse período, ou seja, após o terrorismo revolucionário, sob o governo do Diretório, a sociedade burguesa começa a se desenvolver freneticamente e, por isso, os direitos humanos deixam de existir tão somente na teoria:

\footnotetext{
${ }^{28}$ Na Sagrada Família, a posição desses revolucionários será designada por Marx como "terrorismo", e seus porta-vozes como "terroristas". Nessa passagem da Questão Judaica, Marx indica os primeiros traços dessa caracterização, que será retomada e desenvolvida primeiro nas Glosas Críticas de 1844 e depois na própria Sagrada Família. Essas indicações são preciosas para compor a crítica marxiana ao ponto de vista político ou entendimento político (Glosas Críticas), à superstição política (Sagrada Família), à ilusão política e jurídica ou ideologia política (Ideologia Alemã) ou, no dizer de J. Chasin, ao politicismo - assunto que será o objeto do próximo capítulo.
} 
"precisamente depois da derrubada de Robespierre é que começa a se realizar prosaicamente o iluminismo político que havia querido exceder-se a si mesmo, que havia sido superabundante. Sob o governo do Diretório a sociedade burguesa - a própria Revolução a havia libertado das amarras feudais e reconhecido oficialmente, por mais que o terrorismo tivesse tentado sacrificá-la a uma vida política antiga - irrompe em formidáveis correntes de vida. Tempestade e ímpeto em busca de empresas comerciais, febre de enriquecimento, a vertigem da nova vida burguesa, cujo autogozo inicial ainda é insolente, leviano, frívolo e embriagado; esclarecimento real da propriedade territorial francesa, cuja ordem feudal havia sido destruída pelo martelo da Revolução e que o primeiro ardor febril dos muitos novos proprietários submete agora a um cultivo total; primeiros movimentos da indústria liberada: esses são alguns dos sinais de vida da sociedade burguesa recém-nascida. A sociedade civil é representada positivamente pela burguesia. A burguesia começa, pois, a governar. Os direitos humanos deixam de existir tão-só na teoria" (Sagrada Família, p. 141-142).

Na Ideologia Alemã, Marx não apresenta nenhum desenvolvimento substancial no que se refere à questão dos direitos do homem. Se as conquistas são imensas no que se refere à política e ao direito em geral, o problema específico dos direitos do homem aparece pouquíssimas vezes ao longo do texto e, quando aparece, Marx dá a questão por resolvida, remetendo o leitor direta e explicitamente à Questão Judaica e à Introdução de 1843, publicadas nos Anais Franco-Alemães - o que já é uma evidência da continuidade de sua posição a respeito do tema.

Há basicamente duas passagens em que o tema é referido por Marx. Na primeira, Marx revela que a sua crítica dos direitos do homem é apenas uma parte de sua crítica do direito enquanto tal. Mais ainda, ao mesmo tempo em que reafirma a indissociabilidade entre direito e propriedade privada, marca a incompatibilidade entre comunismo e direito. $\mathrm{E}$ nem se dá ao trabalho de explicar, apenas remetendo às passagens dos Anais FrancoAlemães em que os temas foram tratados:

"No que toca ao direito, já sublinhamos, aliás como muitos outros, a oposição entre o comunismo e o direito, quer se trate do público, do privado ou da sua formulação mais genérica enquanto direitos do homem. Ver os Anais franco-alemães, onde o privilégio é considerado como correspondendo à propriedade privada ligada a um estado [nota: "na acepção que a palavra toma na expressão 'terceiro estado'"], e o direito como correspondendo às condições da concorrência, da propriedade privada livre (pág. 206 e segs.). Do mesmo modo, o próprio direito do homem é estudado enquanto privilégio e a propriedade privada enquanto monopólio. Por outro lado, a crítica do direito é relacionada com a filosofia alemã e apresentada como consequência da crítica da religião (pág. 72); e 
os axiomas do direito, que se afirma deverem conduzir ao comunismo, são concebidos como axiomas da propriedade privada, tal como o direito da propriedade comum é concebido como condição imaginária do direito da propriedade privada (pág. 98-99)" (Ideologia Alemã, v. I, p. 265).

A outra passagem está no capítulo contra Max Stirner. Nela, depois de apresentar a posição do filósofo neo-hegeliano de maneira extremamente irônica, Marx nem se dá ao trabalho de argumentar, e apenas lamenta: "Tudo isto depois de terem sido suficientemente desmascaradas nos Anais franco-alemães as ilusões sobre o Estado e os Direitos do Homem". Esta simples frase demonstra que Marx considera de fato válida a sua crítica do Estado e dos direitos do homem tal como apresentada na Questão Judaica e na Introdução de 1843 e, justamente por isso, confirma a continuidade de sua posição sobre o tema. Vale conferir a passagem na íntegra:

"O nosso mestre-escola [referência irônica a Max Stirner] não deixou de fazer notar que, muito recentemente, se têm confundido os liberais com a bourgeoisie. Dado que São Max confunde a bourgeoisie com os bravos cidadãos, os pequenos-burgueses alemães, nunca interpreta os fatos que Ihe foram transmitidos de acordo com o seu significado real, conforme os expressaram todos os outros componentes, isto é, de modo a revelar nas fórmulas liberais a expressão idealista dos interesses reais da bougeoisie. $\mathrm{Na}$ sua opinião, o fim último do bourgeois é converter-se num liberal perfeito, num cidadão. Para ele, não é o bourgeois que é a verdade do citoyen, mas o citoyen que é a verdade do burgeois. Servindo-se desta concepção, tão sagrada como alemã, vai ao ponto de, na página 130 , transformar 'a burguesia' (deve ler-se: o domínio da bourgeoisie) 'numa ideia, nada mais do que uma ideia', e de apresentar 'o Estado' como 'o homem verdadeiro' que, através dos 'Direitos do homem', atribui a cada bourgeois individualmente os direitos do Homem, conferindo-lhe assim a verdadeira consagração. Tudo isto depois de terem sido suficientemente desmascaradas nos Anais franco-alemães as ilusões sobre o Estado e os Direitos do Homem [...]" (Ideologia Alemã, v. I, p. 246).

E, em nota, esclarece:

"[Nota de Marx e Engels:] Nos An[ais] franco-al[emães], dado o contexto, essas ilusões só eram desmascaradas relativamente aos Direitos do homem da Revolução francesa. Aliás, esta concepção da concorrência como 'Direitos do homem' já se encontra um século antes nos porta-vozes da bourgeoisie (John Hamp[den], Petty, Boisguillebert, Child, etc.)" (Ideologia Alemã, v. I, p 246-247). 


\title{
3. Igualdade e liberdade: categorias da troca de equivalentes
}

\author{
"Igualdade e liberdade, por conseguinte, não \\ apenas são respeitadas na troca baseada em \\ valores de troca, mas a troca de valores de troca é \\ a base produtiva, real, de toda igualdade e \\ liberdade. Como ideias puras, são simples \\ expressões idealizadas dessa base; quando \\ desenvolvidas em relações jurídicas, políticas e \\ sociais, são apenas essa base em uma outra \\ potência" (Grundrisse, p. 188).
}

Como vimos, na Questão Judaica, na Sagrada Família e na Ideologia Alemã Marx identifica o direito como um produto necessário da propriedade privada e da livre concorrência. Entretanto, em textos posteriores, Marx é mais específico a esse respeito. $\mathrm{O}$ direito e suas categorias fundamentais surgem então como derivação necessária da relação de troca entre equivalentes.

Historicamente, o direito moderno, fruto do desenvolvimento da propriedade privada, toma como base o direito privado romano. Entretanto, segundo Marx, isso só acontece na medida em que o direito privado romano já contém as determinações da pessoa jurídica, isto é, as determinações do indivíduo da troca. Aqui, já aparece nitidamente a relação imediata existente entre a troca e o direito. Nas palavras de Marx nos Grundrisse,

\footnotetext{
"é igualmente claro que esse direito [o direito romano], embora corresponda a uma situação social na qual a troca não estava de modo algum desenvolvida, pôde, entretanto, na medida em que estava desenvolvida em determinado círculo, desenvolver as determinações da pessoa jurídica, precisamente as do indivíduo da troca, e antecipar, assim, o direito da sociedade industrial (em suas determinações fundamentais)" (Grundrisse, p. 188-189).
}

Vale enfatizar: segundo Marx, as determinações fundamentais do direito moderno são as determinações da pessoa jurídica ou, mais precisamente, as determinações do indivíduo da troca. Essas determinações fundamentais já surgem no direito privado romano, na medida em que a troca já estava desenvolvida, ainda que apenas em um círculo reduzido, na Roma antiga.

No Capital, com seu sarcasmo costumeiro, Marx faz um resumo dessas determinações fundamentais, na sua expressão mais geral enquanto direitos do homem, 
demonstrando-as enquanto determinações inerentes à troca de mercadorias e, portanto, à esfera da circulação simples:

\begin{abstract}
"A esfera que estamos abandonando, da circulação ou da troca de mercadorias, dentro da qual se operam a compra e a venda da força de trabalho, é realmente um verdadeiro paraíso dos direitos inatos do homem. Só reinam aí liberdade, igualdade, propriedade e Bentham. Liberdade, pois o comprador e o vendedor de uma mercadoria, a força de trabalho, por exemplo, são determinados apenas pela sua vontade livre. Contratam como pessoas livres, juridicamente iguais. O contrato é o resultado final, a expressão jurídica comum de suas vontades. Igualdade, pois estabelecem relações mútuas apenas como possuidores de mercadorias e trocam equivalente por equivalente. Propriedade, pois cada um só dispõe do que é seu. Bentham, pois cada um dos dois só cuida de si mesmo. A única força que os junta e os relaciona é a do proveito próprio, da vantagem individual, dos interesses privados. E justamente por cada um só cuidar de si mesmo, não cuidando ninguém dos outros, realizam todos, em virtude de uma harmonia preestabelecida das coisas, ou sob os auspícios de uma providência onisciente, apenas as obras de proveito recíproco, de utilidade comum, de interesse geral" (Capital, Livro I, Volume I, Bertrand Brasil, p. 197).
\end{abstract}

De maneira profundamente irônica, vemos as principais determinações do direito (liberdade, igualdade e propriedade) serem associadas imediatamente às determinações fundamentais da relação de troca entre mercadorias. Esse trecho concretiza significativamente a posição, enunciada desde a Questão Judaica, a Sagrada Família e a Ideologia Alemã, de que os direitos do homem são os direitos da livre concorrência. Porém, é nos Grundrisse que encontramos a exposição mais detalhada de Marx a esse respeito.

Nos Grundrisse, Marx faz uma análise detalhada da forma da relação de troca entre equivalentes e demonstra que as categorias de liberdade e igualdade derivam justamente desta relação. Na verdade, igualdade e liberdade são formas assumidas necessariamente pela relação de troca. E isso, primeiro no sentido econômico, mas também, imediatamente, no sentido jurídico. Antes de tudo, portanto, esta igualdade e esta liberdade, longe de serem categorias universais, são categorias históricas, derivadas de uma forma social em que o objetivo primordial da produção é a troca.

A esfera da troca, ou esfera da circulação simples, é identificada por Marx como a superfície da sociedade capitalista, na qual as antíteses mais profundas, pertencentes à esfera da produção, estão apagadas. 
"No conjunto da sociedade burguesa existente, esse pôr como preços e sua circulação etc. aparece como o processo superficial sob o qual, no entanto, na profundidade, sucedem processos inteiramente diferentes, nos quais desaparece essa aparente igualdade e liberdade dos indivíduos" (Grundrisse, p. 190).

Trata-se da aparência da sociedade capitalista. Porém, da aparência no sentido objetivo, ou seja, no sentido de que é assim que ela efetivamente aparece na realidade. A contradição entre a sua aparência e a sua essência é uma contradição objetiva, é a maneira específica pela qual a sociedade capitalista se efetiva. No nosso tema específico, isso fica ainda mais nítido, uma vez que a igualdade e a liberdade, que efetivamente existem e são respeitadas na superfície, na esfera da troca, acabam por se realizar, na esfera da produção, como desigualdade e escravidão.

Marx começa por analisar a igualdade enquanto categoria fundamental da relação de troca. O primeiro aspecto a ressaltar é que, na relação de troca, os indivíduos aparecem unicamente sob a qualidade de trocadores, ou seja, de comprador ou vendedor, e todas as suas outras determinações são ignoradas.

"No assim chamado comércio a varejo, no intercâmbio cotidiano da vida burguesa, como se dá diretamente entre produtores e consumidores, no pequeno comércio, no qual a finalidade é, de um lado, a troca de mercadoria por dinheiro e, de outro, a troca de dinheiro por mercadoria para a satisfação de necessidade individuais - é somente nesse movimento, que transcorre na superfície do mundo burguês, que o movimento dos valores de troca, sua circulação, se realiza de maneira pura. Um trabalhador que compra um pão e um milionário que faz o mesmo aparecem nesse ato só como simples compradores, do mesmo modo que o comerciante aparece frente a eles apenas como vendedor. Todas as outras determinações estão aqui canceladas. O conteúdo de suas compras, bem como o seu volume, aparece completamente indiferente diante dessa determinação formal" (Grundrisse, p. 193).

Não importa se é um trabalhador ou um milionário, ambos aparecem enquanto formalmente iguais na relação de troca, na medida em que ambos são apenas considerados enquanto trocadores: 
"Cada um dos sujeitos é um trocador, i.e., cada um tem a mesma relação social com o outro que o outro tem como ele. A sua relação como trocadores é, por isso, a relação da igualdade" (Grundrisse, p. 185).

A igualdade surge então, desde já, como igualdade meramente formal, isto é, como indiferença às peculiaridades individuais:

"como sujeitos de igual valor, são ao mesmo tempo indiferentes uns aos outros, suas outras diferenças individuais não lhes interessam; são indiferentes a todas as suas outras peculiaridades individuais" (Grundrisse, p. 185).

A igualdade que existe entre os sujeitos da troca se verifica também entre os objetos trocados e no próprio ato da troca:

\begin{abstract}
"Na medida em que é considerada a forma pura, o lado econômico da relação [...], destacam-se então apenas três momentos formalmente distintos: os sujeitos da relação, os trocadores, postos na mesma determinação; os objetos de sua troca, valores de troca, equivalentes, que não apenas são iguais, mas devem ser expressamente iguais e são postos como iguais; e finalmente o próprio ato da troca, a mediação pela qual os sujeitos são postos precisamente como trocadores, como iguais, e seus objetos postos como equivalentes, como iguais" (Grundrisse, p. 185).
\end{abstract}

Sendo assim, a forma da relação de troca não apenas pressupõe como afirma a igualdade, tanto entre os sujeitos como entre os objetos da troca. Não se trata de uma mentira, de uma farsa. A igualdade se realiza efetivamente enquanto igualdade formal, isto é, enquanto indiferença às particularidades reais.

Como vemos, esta igualdade é um produto necessário da relação de troca ou, mais ainda, é a forma necessariamente assumida por essa relação econômica fundamental. Assim como os produtos do trabalho, na sociedade capitalista, assumem necessariamente a forma de mercadorias, a própria relação social, baseada na troca, assume a forma da igualdade. A igualdade é, portanto, a forma da relação social baseada na relação de troca de mercadorias. Além da igualdade, a relação de troca pressupõe também a liberdade e a propriedade, na medida em que a troca não é realizada pela força, mas através de um contrato entre vontades livres, e que cada um só dispõe do que é seu: 
"Ainda que o indivíduo $A$ sinta necessidade da mercadoria do indivíduo $B$, não se apodera dela pela força, nem vice-versa, mas reconhecem-se mutuamente como proprietários, como pessoas cuja vontade impregna suas mercadorias. Em decorrência, aqui entra de imediato o momento jurídico da pessoa e da liberdade, na medida em que está contida na primeira. Nenhum deles se apodera da propriedade do outro pela força. Cada um a cede voluntariamente" (Grundrisse, p. 187).

Por fim, a relação de troca contém ainda o que Marx chamou no Capital, ironicamente, de "Bentham". Trata-se, na realidade, do interesse egoísta, isto é, dos interesses contrapostos, sem ligação uns com os outros, da utilização recíproca do outro enquanto meio:

"Mas isso não é tudo: o indivíduo $A$ serve à necessidade do indivíduo $B$ por meio da mercadoria $a$ somente na medida em que, e porque, o indivíduo $B$ serve à necessidade do indivíduo $\mathrm{A}$ por meio da mercadoria $b$ e vice-versa. Cada um serve ao outro para servir a si mesmo, cada um se serve reciprocamente do outro como seu meio" (Grundrisse, p. 187).

Entretanto,

"essa reciprocidade tem interesse para o indivíduo apenas na medida em que satisfaz seu interesse, como interesse que exclui o interesse do outro, sem ligação com ele" (Grundrisse, p. 187).

Com isso, Marx desmistifica a ideia de que a troca é a realização do interesse comum, de um pretenso interesse maior, que não apenas os interesses egoístas contrapostos entre si:

"O que significa dizer que o interesse comum, que aparece como motivo do ato como um todo, é certamente reconhecido como fato por ambas as partes, mas não é motivo enquanto tal, ao contrário, atua, por assim dizer, por detrás dos interesses particulares refletidos em si mesmo, do interesse singular contraposto ao do outro" (Grundrisse, p. 187).

Dessa maneira,

“Pelo próprio ato da troca, o indivíduo, cada um dos indivíduos, está refletido em si mesmo como sujeito exclusivo e dominante (determinante) do ato da troca" (Grundrisse, p. 187). 
O interesse comum é desmascarado, assim, não como um interesse superior, maior, mas apenas enquanto a universalidade dos interesses egoístas:

\begin{abstract}
"Com isso, portanto, está posta a completa liberdade do indivíduo: transação voluntária; nenhuma violência de parte a parte; posição de si como meio, ou a serviço, unicamente como meio de se pôr como fim em si, como o dominante e o prevalecente; enfim, o interesse egoísta, que não realiza nenhum interesse superior; o outro também é reconhecido e conhecido como sujeito que realiza seu interesse egoísta exatamente da mesma maneira, de modo que ambos sabem que o interesse comum consiste precisamente na troca do interesse egoísta em sua bilateralidade, multilateralidade e autonomização. $O$ interesse universal é justamente a universalidade dos interesses egoístas" (Grundrisse, p. 187-188).
\end{abstract}

Sendo assim, nas palavras incisivas e conclusivas de Marx:

\begin{abstract}
"Igualdade e liberdade, por conseguinte, não apenas são respeitadas na troca baseada em valores de troca, mas a troca de valores de troca é a base produtiva, real, de toda igualdade e liberdade. Como ideias puras, são simples expressões idealizadas dessa base; quando desenvolvidas em relações jurídicas, políticas e sociais, são apenas essa base em uma outra potência" (Grundrisse, p. 188).
\end{abstract}

Marx é categórico: a igualdade e a liberdade, seja enquanto ideias puras, seja enquanto relações jurídicas, políticas e sociais, são categorias inerentes à troca de mercadorias. Isso significa que a igualdade e a liberdade, enquanto categorias fundamentais do direito, são derivadas dessa relação econômica fundamental.

Porém, como vimos, considerar a esfera da troca de mercadorias isoladamente é considerar apenas a superfície do sistema capitalista, na qual todas as contradições mais profundas simplesmente desaparecem, como se não existissem, restando apenas abstrações puras.

"Toda essa sabedoria, portanto, em nada mais consiste do que parar nas relações econômicas mais simples, as quais, tomadas autonomamente, são puras abstrações; abstrações que na realidade são mediadas pelas mais profundas antíteses e só mostram um lado, aquele em que a expressão das antíteses está apagada" (Grundrisse, p. 191). 
Entretanto, isso não significa que essa superfície não seja real. Pelo contrário, como vimos, para Marx igualdade e liberdade não apenas são respeitadas como também são derivadas da relação de troca entre mercadorias. A questão é que essa superfície não existe isoladamente e que a troca de mercadorias só existe integrada à esfera da produção, onde se revelam as mediações mais profundas e contraditórias do sistema. Ou seja, a igualdade e a liberdade, que de fato existem na esfera da circulação simples, se realizam necessariamente como desigualdade e escravidão na esfera da produção. Nas palavras de Marx:

"o valor de troca ou, mais precisamente, o sistema monetário é de fato o sistema da igualdade e liberdade, e as perturbações que enfrentam no desenvolvimento ulterior do sistema são perturbações a ele imanentes, justamente a efetivação da liberdade e igualdade, que se patenteiam como desigualdade e ausência de liberdade" (Grundrisse, p. 191).

É com base nisso que, com seu costumeiro sarcasmo, Marx critica a tolice dos socialistas, especialmente os franceses, com destaque especial para Proudhon:

\begin{abstract}
"Por outro lado, evidencia-se igualmente a tolice dos socialistas (notadamente os franceses, que querem provar que o socialismo é a realização das ideias da sociedade burguesa expressas pela Revolução Francesa), que demonstram que a troca, o valor de troca etc. são originalmente (no tempo) ou de acordo com o seu conceito (em sua forma adequada) um sistema da liberdade e igualdade de todos, mas que têm sido deturpados pelo dinheiro, pelo capital etc. Ou ainda, que a história só fez até o momento tentativas malsucedidas de realizá-las de um modo corresponde à sua verdade, e agora os socialistas, como Proudhon, por exemplo, descobriram o verdadeiro Jacob, com o que deve ser providenciada a genuína história dessas relações, em lugar de sua falsa história" (Grundrisse, p. 191).
\end{abstract}

Assim como o Estado não é um instrumento neutro de organização social que pode ser direcionado para finalidades emancipatórias, assim também a igualdade e a liberdade, enquanto categorias fundamentais do direito, não podem ser entendidas como categorias universais, mas apenas enquanto categorias imanentes à sociedade capitalista e, mais precisamente, à relação de troca entre mercadorias. Sendo assim, esta liberdade e esta igualdade são categorias que estão de fato realizadas na esfera da troca e que, no desenvolvimento do sistema, necessariamente se desdobram no seu oposto, em 
desigualdade e escravidão. Assim como não é possível isolar a esfera da circulação da esfera da produção, assim também não é possível isolar a igualdade e liberdade do seu ulterior desdobramento enquanto desigualdade e escravidão. Em termos econômicos, o valor de troca se desdobra necessariamente em capital, assim como o trabalho que produz valor de troca se desdobra necessariamente em trabalho assalariado. Sendo assim, propor a realização verdadeira ou correta desta igualdade e desta liberdade é não compreendê-las em sua efetividade, mas apenas em sua abstração, isolada das mediações mais profundas.

\begin{abstract}
"É tão piedoso quanto tolo desejar que o valor de troca não se desenvolva em capital, ou que o trabalho produtor de valor de troca não se desenvolva em trabalho assalariado. $O$ que distingue esses senhores dos apologistas burgueses é, de um lado, a sensibilidade das contradições que o sistema encerra; de outro, o utopismo, não compreender a diferença necessária entre a figura real e ideal da sociedade burguesa e, consequentemente, pretender assumir o inútil empreendimento de querer realizar novamente a própria expressão ideal, expressão que de fato nada mais é do que a fotografia dessa realidade" (Grundrisse, p. 191).
\end{abstract}

\title{
4. Fechamento
}

Embora Marx não tenha dedicado nenhum texto exclusivamente à crítica do direito enquanto tal, como pudemos perceber, as diversas passagens da sua obra em que o tema aparece revelam uma concepção significativamente coerente a esse respeito.

Para Marx, o direito não é uma categoria eterna da vida social, mas sim uma categoria historicamente circunstancial - é uma forma assumida pelas relações sociais num determinado momento histórico, tão necessária quanto transitória. Não é um valor universal e tampouco possui a capacidade de instituir a liberdade humana, mas, ao contrário, é a sanção e a garantia da escravidão da sociedade civil, isto é, da propriedade privada moderna, na qual se baseia a sociedade capitalista. O direito e a propriedade privada, segundo Marx, são irmãos siameses, absolutamente indissociáveis. Não há propriedade privada sem direito, assim como não há direito sem propriedade privada.

Sendo assim, de acordo com Marx, não há como corrigir esta organização social a partir do direito, e nem há como corrigir o próprio direito enquanto tal. Suas limitações não são circunstanciais, mas intrínsecas, fazem parte de sua própria natureza. Para ser corrigido, 
o direito precisaria deixar de ser direito. Ou seja, longe de aparecer como um meio de libertação, o direito aparece como um instrumento de escravização, na exata medida em que serve à propriedade privada.

Com base nisso, fica evidente que uma transformação radical da organização social a partir do direito, para Marx, não passa de mais um sonho piedoso dos socialistas. Da mesma maneira, um direito proletário é uma contradição em termos. Para Marx, uma revolução socialista não implica a invenção e instituição de uma nova forma de direito, mas sim a abolição do direito enquanto tal. Assim como o Estado e o poder político, para Marx o direito está em contradição direita com a efetivação da liberdade humana. $E$ isso vale para todas as formas do direito, incluindo a sua expressão mais geral, enquanto direitos humanos. Sendo assim, para Marx, o prosseguimento do processo de construção da liberdade humana só pode se dar para além do direito enquanto tal. 


\section{CRÍTICA DA SUPERSTIÇÃO POLÍTICA}

$\mathrm{Na}$ Questão Judaica, como vimos, Marx se refere à ilusão de ótica dos revolucionários; nas Glosas de 1844, ao ponto de vista político ou entendimento político; na Sagrada Família, à superstição política e à ilusão gigantesca dos terroristas revolucionários; na Ideologia Alemã, à ideologia política e às ilusões dos juristas e dos políticos (incluindo os estadistas práticos); no 18 de Brumário, ao viés democrático; na Guerra Civil na França, aos olhos turvos que veem apenas a superfície política; e, por fim, na Crítica de Gotha, à superstição democrática e às patranhas ideológicas e jurídicas tão em voga entre os democratas e os socialistas franceses. Essas expressões traduzem, cada uma à sua maneira, diversos aspectos de uma mesma crítica de Marx, que se encontra dispersa ao longo de sua obra, assim como toda a sua crítica da política. Neste capítulo, o objetivo será justamente apresentar esses diversos elementos de forma organizada, demonstrando não apenas que possuem uma unidade facilmente verificável, como também que se trata de um momento privilegiado para a compreensão da natureza específica da crítica de Marx à política. ${ }^{29}$

O capítulo está dividido em duas grandes partes: a primeira é voltada à crítica da ilusão política em seu aspecto teórico, o que inclui os historiadores, os filósofos, os juristas e as próprias declarações de direitos do homem; e a segunda ao seu aspecto prático, ou seja, à atuação política prática, o que inclui os estadistas, como Napoleão e Frederico Guilherme IV, os revolucionários franceses e as próprias insurreições operárias.

Na primeira parte, voltada ao aspecto teórico, será abordada em primeiro lugar a crítica de Marx ao ponto de vista do indivíduo isolado, ou seja, à naturalização do indivíduo da sociedade burguesa, compartilhada tanto pelos filósofos contratualistas e pela economia política, quanto pelos juristas, pelos códigos de direito e pelas declarações de direitos humanos. Neste contexto, será evidenciado que a coesão entre os indivíduos, longe de ser determinada pela política, é antes imposta pelas necessidades e pelo modo de as satisfazer, e por isso é tão antiga quanto os homens. Em segundo lugar, será exposta a crítica à ideologia política, que arranca a política de sua base real, isto é, das relações materiais da

\footnotetext{
${ }^{29}$ A identificação dessa unidade crítica é devida a José Chasin, que a designou de crítica do politicismo, termo que permite sintetizar todas essas expressões utilizadas por Marx com uma mesma finalidade. Ver: CHASIN, José. Ensaios Ad Hominem. São Paulo: Ad Hominem, 2000, n. 1, tomo III (Política).
} 
vida, e a estabelece como categoria eterna e determinante da vida social. Por fim, será desenvolvida a crítica de Marx à ilusão jurídica, que compreende a vontade ideológica (isto é, a vontade arrancada de sua base real) como a base do direito.

Na segunda parte, voltada ao aspecto prático, em primeiro lugar será desenvolvida a crítica de Marx ao entendimento político, tal como aparece nas Glosas de 1844, onde Marx analisa a relação entre o Estado (governantes, partidos, legislação etc.) e os problemas sociais, especificamente a miséria. Aqui, Marx demonstra que o Estado é intrinsecamente impotente diante dos males sociais, uma vez que ele está assentado sobre a fonte real desses males, a sociedade civil, à qual se encontra organicamente vinculado e à qual serve de garantia. Da mesma forma, o entendimento político, quanto mais perfeito, mais será incapaz de compreender a origem desses males, visto que, justamente por pensar dentro dos limites da política, não consegue apreender a natureza do Estado. Em segundo lugar, será abordada a crítica de Marx à ilusão gigantesca dos revolucionários franceses, ilusão compartilhada parcialmente por Napoleão. Por conceberem o Estado como um fim em si mesmo e, portanto, como a esfera determinante da vida social, ou seja, por não compreenderem que o Estado moderno está organicamente vinculado à moderna sociedade burguesa, sendo na verdade seu servo, ambos serviram-se do Estado, em maior ou menos medida, para tentar abafar os seus próprios pressupostos, no que necessariamente fracassaram. Em terceiro lugar, será exposta a ilusão política dos trabalhadores, quando dirigem suas revoltas à esfera política, contra uma determinada forma de governo, por exemplo, e não, como deveriam fazer, contra a própria organização da sociedade burguesa, que é a base real do Estado e a verdadeira fonte dos problemas sociais. Aqui, será apenas indicada a crítica de Marx à revolução política, que será desenvolvida com maior detalhe no próximo capítulo. 


\title{
1. Superstição política teórica
}

\subsection{Crítica do ponto de vista do indivíduo isolado: as robinsonadas}

\begin{abstract}
"O homem é no sentido mais literal, um zoon politikon, não só animal social, mas animal que só pode isolar-se em sociedade" (Introdução de 1857, p. 4).
\end{abstract}

No capítulo anterior, abordamos a crítica de Marx à ilusão de ótica dos revolucionários franceses nas declarações dos direitos do homem, tal como exposta pelo autor na sua Questão Judaica. Vimos que, nas declarações, o homem da sociedade civil é apresentado como homem natural e a sociedade aparece como simples meio para a vida do indivíduo privado. Naquela ocasião, Marx atribui a causa dessa ilusão de ótica à limitação da natureza da revolução política, ou seja, ao fato de a revolução política dissolver a velha sociedade sem revolucionar as suas componentes. ${ }^{30}$ No final do século XVIII, segundo MarX, o indivíduo burguês, isto é, o homem egoísta, separado dos outros homens e da comunidade, produto da propriedade privada moderna, já é o fundamento da sociedade feudal. A revolução política, ao dissolver a velha sociedade sem revolucionar esse fundamento, trata na prática o indivíduo burguês como um pressuposto inteiramente subsistente, como sua base natural. A própria ação revolucionária, por se concentrar na ação política e, portanto, por não abalar os pilares do edifício, gera a aparência de que o homem da sociedade civil, isto é, o indivíduo burguês, completamente separado da comunidade, é o homem enquanto tal, o homem em sua natureza, o homem natural; e seus direitos, direitos naturais.

Anos mais tarde, por conta de seus estudos de economia política, Marx retorna a esse tema, da naturalização do indivíduo da sociedade burguesa, na medida em que a economia política, assim como os revolucionários franceses, toma como ponto de partida o indivíduo isolado. De acordo com Marx, essa ilusão, de que o indivíduo é naturalmente isolado, pertence às "pobres ficções das robinsonadas do século XVIII", ou seja, à corrente teórica que ficou conhecida como contratualismo.

\footnotetext{
${ }^{30}$ A crítica de Marx à revolução política, que já encontra seu primeiro embrião na Questão Judaica, será analisada com maior detalhe no próximo capítulo, sobre a emancipação humana.
} 
Segundo a filosofia contratualista, os indivíduos são naturalmente isolados e só se reúnem em sociedade por meio de um contrato; não apenas a coesão social é dada pelo Estado como a finalidade confessa da sociedade é a vida do indivíduo privado. Essa concepção é para Marx um exemplo típico da superstição política. Na Introdução de 1857, Marx faz a crítica dessa ilusão, sustentando que na verdade o isolamento do indivíduo é um produto histórico, mais especificamente, um produto da sociedade civil moderna, gestada a partir do século XVI e já madura no século XVIII. De acordo com Marx, como vimos no primeiro capítulo, a conexão social é tão antiga quanto os homens e a existência humana é sempre e necessariamente social. Este indivíduo isolado, que é transportado para um passado fictício ou para a natureza do homem e postulado como ponto de partida da história, é na verdade uma antecipação do indivíduo isolado que surge com a sociedade civil no século XVIII. Só então, com o desenvolvimento da propriedade moderna e da livre concorrência, dissolvem-se os laços entre o indivíduo e a comunidade, laços que existiam desde a família, a tribo e as formas de comunidade antiga e medieval. Só então surge na realidade, como resultado histórico, o indivíduo que os "profetas do século XVIII" idealizaram como indivíduo natural e como ponto de partida da história. Vale acompanhar a argumentação de Marx na íntegra:

"Indivíduos produzindo em sociedade, portanto a produção dos indivíduos determinada socialmente, é por certo o ponto de partida. O caçador e o pescador, individuais e isolados, de que partem Smith e Ricardo, pertencem às pobres ficções das robinsonadas do século XVIII. [...] Trata-se, ao contrário, de uma antecipação da 'sociedade' (bürgelichen Gesellschaft), que se preparava desde o século XVI, e no século XVIII deu larguíssimos passos em direção à sua maturidade. Nesta sociedade da livre concorrência, o indivíduo aparece desprendido dos laços naturais que, em épocas históricas remotas, fizeram dele um acessório de um conglomerado humano limitado e determinado. Os profetas do século XVIII, sobre cujos ombros se apoiam inteiramente Smith e Ricardo, imaginam este indivíduo do século XVIII - produto, por um lado, da decomposição das formas feudais de sociedade e, por outro, das novas forças de produção que se desenvolvem a partir do século XVI - como um ideal, que teria existido no passado. Veem-no não como um resultado histórico, mas como ponto de partida da História, porque o consideravam como um indivíduo conforme à natureza - dentro da representação que tinham de natureza humana -, que não se originou historicamente, mas foi posto como tal pela natureza. Esta ilusão tem sido partilhada por todas as novas épocas até o presente. Steuart, que em muitos aspectos se opõe ao século XVIII e que na sua condição de aristocrata se situa mais sobre o terreno histórico, escapou desta ingenuidade" (Introdução de 1857, p. 3-4). 
E, logo adiante:

\begin{abstract}
"Quanto mais se recua na história, mais dependente aparece o indivíduo, e portanto, também o indivíduo produtor, e mais amplo é o conjunto a que pertence. De início, este aparece de um modo ainda muito natural, numa família e numa tribo, que é família ampliada; mais tarde, nas diversas formas de comunidade resultantes do antagonismo e da fusão das tribos. Só no século XVIII, na 'sociedade burguesa', as diversas formas do conjunto social passaram a apresentar-se ao indivíduo como simples meio de realizar seus fins privados, como necessidade exterior. Todavia, a época que produz este ponto de vista, o do indivíduo isolado, é precisamente aquela na qual as relações sociais (e, deste ponto de vista, gerais) alcançaram o mais alto grau de desenvolvimento. O homem é no sentido mais literal, um zoon politikon, não só animal social, mas animal que só pode isolar-se em sociedade" (Introdução de 1857, p. 4).
\end{abstract}

Na realidade, segundo Marx, só existem e só existiram até então homens vivendo em sociedade. Longe de ser dado naturalmente, o isolamento do indivíduo é resultado de um longo processo histórico. Naturalmente social, o homem só pode isolar-se em sociedade. Quanto mais antiga a época, mais o indivíduo aparece vinculado aos laços comunitários. A dissolução desses laços e o consequente isolamento do indivíduo ocorrem como resultado de um longo processo histórico, que atinge sua maturidade apenas no século XVIII, com o surgimento da sociedade civil.

Não é à toa, segundo Marx, que este ponto de vista, o do indivíduo isolado, tenha surgido exatamente nessa época, entre os séculos XVI e XVIII, ou seja, no período de gestação dessa nova configuração social, e que tenha perdurado não apenas até os tempos de Marx, como até os dias de hoje. De qualquer maneira, segundo Marx, essas "pobres ficções das robinsonadas do século XVIII" não passam de uma "ilusão", uma "ingenuidade", uma "banalidade que teve sentido e razão entre os homens do século XVIII" (Introdução de 1857, p. 4).

De acordo com Marx, além dos revolucionários franceses nas declarações de direitos humanos, dos economistas políticos e dos filósofos contratualistas, essa ilusão é compartilhada também, e principalmente, pelos juristas e seus códigos de direito. Para eles, as relações entre os indivíduos, longe de serem necessárias, são antes fortuitas e fruto da simples vontade individual. Nas palavras de Marx, 
"Esta ilusão dos juristas também explica o fato de que, para eles e para todos os códigos jurídicos, é algo fortuito que indivíduos estabeleçam relações entre si (por exemplo contratos); explica por que consideram que essas relações [podem] ser estabelecidas de acordo ou não com a vontade, e que seu conteúdo descansa inteiramente sobre o [arbítrio] individual das partes contratantes" (Ideologia Alemã, p. 100). ${ }^{31}$

Assim, seja nas declarações de direito humanos, na economia política, na filosofia contratualista ou no próprio direito (incluindo a teoria jurídica e os códigos de direito), o fundamento é o mesmo, ou seja, a naturalização do indivíduo da sociedade burguesa e a consequente desnaturalização da relação social, que aparece como exterior ao indivíduo, como meio para a garantia e proteção deste indivíduo independente e, mais ainda, como algo fortuito, como fruto da mera vontade. Como veremos ao longo deste capítulo, a crítica de Marx se dirige a cada um desses pontos: o indivíduo não é naturalmente isolado, as relações sociais entre os homens não são fortuitas e nem fruto da mera vontade; ao contrário, a conexão social, uma vez que é determinada pela própria natureza do homem, isto é, pelas suas necessidades e pelo modo de satisfazê-las, é tão antiga quanto os homens, só fazendo sentido pensar a existência humana como existência social. E, por fim, a sociedade não é simples meio para a realização dos fins privados deste indivíduo independente; a coisa aparece assim pois isso é realidade na sociedade burguesa, mas, como veremos no capítulo seguinte, a conexão social é o local por excelência da existência humana e portanto da própria liberdade.

Desde já, portanto, cai por terra a superstição política segundo a qual o que mantém a coesão social entre os homens é o Estado e a política. Mas então o que determina essa coesão?

Na Ideologia Alemã, como vimos no primeiro capítulo, Marx demonstra que a conexão social, tão antiga quanto os próprios homens, é determinada pelas necessidades e pela produção material, e não, como pretende a superstição política ou a ilusão jurídica, pela vontade individual e pelo Estado, ou por "qualquer absurdo político ou religioso". Vale retomar as incisivas palavras de Marx, agora com este foco:

\footnotetext{
${ }^{31}$ Por vezes, Marx reafirma sua posição dirigindo-se explicitamente contra Rousseau e o seu Contrato Social, como nesta passagem: "A união anterior (de forma alguma arbitrária, como é apresentada, por exemplo, no Contrat Social, mas necessária) [...]" (Ideologia Alemã, p. 118).
} 


\begin{abstract}
"Desde o início mostra-se, portanto, uma conexão materialista dos homens entre si, condicionada pelas necessidades e pelo modo de produção, conexão esta que é tão antiga quanto os próprios homens - e que toma, incessantemente, novas formas e apresenta, portanto, uma 'história', sem que exista qualquer absurdo político ou religioso que também mantenha os homens unidos" (Ideologia Alemã, p. 42-43).
\end{abstract}

No capítulo contra Stirner, Marx reafirma essa ideia, demonstrando a inevitabilidade da conexão social entre os indivíduos, uma vez que ela se funda nas necessidades e no modo de as satisfazer, portanto na própria natureza dos homens:

\begin{abstract}
"Os indivíduos 'partiram', sempre e em quaisquer circunstâncias, 'deles próprios', mas eles não eram únicos no sentido de que não poderiam deixar de ter relações entre si; pelo contrário, suas necessidades, portanto a sua natureza, e a maneira de as satisfazer [modo de produção da vida material], tornava-os dependentes uns dos outros (relações entre os sexos, trocas, divisão do trabalho); era portanto inevitável que se estabelecessem relações entre eles" (Ideologia Alemã, v. II, p. 300).
\end{abstract}

Em uma passagem extremamente sarcástica e bem humorada da Sagrada Família, Marx reafirma a ideia de que a coesão entre os indivíduos é dada socialmente e não politicamente, mas agora referindo-se especificamente ao indivíduo egoísta da sociedade burguesa. Trata-se de uma critica à ideia de Bauer segundo a qual "a essência geral do Estado tem de manter a coesão dos átomos egoístas individuais" (Sagrada Família, p. 139). Aqui, por um lado, Marx traz à tona frutos de seus estudos sobre economia política que resultaram nos Manuscritos de 1844 e, por outro, "antecipa" a crítica da superstição política presente na Ideologia Alemã. Acompanhemos a sua argumentação na íntegra:

"A rigor, e falando em sentido prosaico, os membros da sociedade burguesa não são átomos. A qualidade característica do átomo consiste em não ter nenhuma qualidade e, portanto, nenhuma classe de relações, condicionadas por sua própria necessidade natural, com outros entes fora dele. $\mathrm{O}$ átomo carece de necessidades, basta-se a si mesmo; o mundo fora dele é o vazio absoluto; quer dizer, esse mundo carece de conteúdo e de sentido, não diz nada, precisamente porque possui em si mesmo toda a plenitude. $\mathrm{O}$ indivíduo egoísta da sociedade burguesa pode, em sua representação insensível e em sua abstração sem vida, enfunar-se até converter-se em átomo, quer dizer, em um ente bem-aventurado, carente de relações e de necessidades, que se basta a si mesmo e é dotado de plenitude absoluta. Mas a desditada realidade sensível faz pouco caso de 
sua representação; cada um de seus sentidos o obriga a acreditar no sentido do mundo e dos indivíduos fora dele, e inclusive seu estômago profano faz com que ele recorde diariamente que o mundo fora dele não é um mundo vazio, mas sim aquilo que ele na verdade preenche. Cada uma de suas atividades essenciais se converte em necessidade, em imperativo, que incita o seu egoísmo a buscar outras coisas e outros homens, fora de si mesmo. Todavia, como a necessidade de um determinado indivíduo não tem, para um outro indivíduo egoísta que possui os meios de satisfazer essa necessidade, um sentido que possa ser compreendido por si mesmo, como a necessidade não tem, portanto, relação imediata com sua satisfação, cada indivíduo tem de criar necessariamente essa relação, convertendo-se também em mediador entre a necessidade alheia e os objetos dessa necessidade." (Sagrada Família, p. 139).

O átomo é um ser autossuficiente, pleno e, portanto, carente de necessidades e relações. $O$ indivíduo da sociedade burguesa, por mais que na sua fantasia se represente como tal, está longe de ser um átomo, uma vez que ele possui necessidades, como a fome, que só podem ser satisfeitas através de objetos que estão fora dele e , por isso, precisa criar a relação com outros indivíduos que possuem esses objetos. Com base nisso, Marx apresenta a sua conclusão, que aliás é afirmada e reafirmada, não deixando margem para dúvidas:

\footnotetext{
"Por conseguinte, a necessidade natural, as qualidades essencialmente humanas, por estranhas que possam parecer umas às outras, e o interesse mantêm a coesão entre os membros da sociedade civil; e a vida civil e não a vida política é o seu vínculo real. Não é, pois, o Estado que mantém coesos os átomos da sociedade civil, mas eles são átomos apenas na representação, no céu de sua própria imaginação... na realidade, no entanto, eles são seres completa e enormemente diferentes dos átomos, ou seja, nenhuns egoístas divinos, mas apenas homens egoístas. Somente a superstição política ainda pode ser capaz de imaginar que nos dias de hoje a vida civil deve ser mantida em coesão pelo Estado, quando na realidade o que ocorre é o contrário, ou seja, é o Estado quem se acha mantido em coesão pela vida civil" (Sagrada Família, p. 139).
}

Aqui, Marx não deixa dúvidas: é a vida civil e não a vida política quem mantém a coesão entre os indivíduos; e o próprio Estado só se mantém coeso pela vida civil. Como vimos, ao longo de toda a Sagrada Família e de toda a sua obra, Marx insiste no fato de que o Estado tem como base real a sociedade civil e de que é um produto do desenvolvimento desta. Romper esta determinação fundamental só pode conduzir à superstição política, que 
considera o Estado como um ser autônomo, com fundamento próprio, que teria criado a sociedade civil e seria responsável por sua manutenção.

Não só os homens não se reúnem sem sociedade, uma vez que a sociedade é tão antiga quanto os homens, como a forma desta sociedade não pode ser escolhida livremente. Segundo Marx, a ideia de que a forma assumida pela sociedade em cada período pode ser determinada pela vontade livre dos homens ou por decisões políticas é mais um produto da superstição política. Não são as formas políticas que determinam as formas sociais, mas as formas sociais que determinam as formas políticas. E a forma assumida pela sociedade em cada caso é determinada pelo nível de desenvolvimento das forças produtivas. É o que sustenta Marx contra Proudhon em sua Carta a Annenkov. Vale retomar suas palavras, agora com este novo foco:

\begin{abstract}
"Que é a sociedade, qualquer que seja sua forma? O produto da ação recíproca dos homens. Podem os homens escolher, livremente, essa ou aquela forma social? Nada disso. A um determinado nível de desenvolvimento das forças produtivas dos homens, corresponde determinada forma de comércio e de consumo. A determinadas fases de desenvolvimento da produção, do comércio e do consumo, correspondem determinadas formas de constituição social, determinada organização da família, dos estamentos ou das classes; em uma palavra, uma determinada sociedade civil. A uma determinada sociedade civil, corresponde um determinado regime político, que não é mais do que a expressão oficial da sociedade civil. Isso é o que o Sr. Proudhon jamais chegará a compreender, pois acredita que fez uma grande coisa, apelando do Estado à sociedade civil, isto é, do resumo oficial da sociedade à sociedade oficial" (Carta a Annenkov, p. 170).
\end{abstract}

Nos Grundrisse, no trecho conhecido como Formações Econômicas Pré-Capitalistas, há diversas passagens em que Marx reafirma categoricamente essa crítica ao isolamento natural do indivíduo e à ideia de que a união em sociedade é um fruto da política. Segundo Marx,

"A filiação a uma sociedade naturalmente evoluída, uma tribo, etc., é uma condição natural de produção de um ser humano" (Formações Econômicas Pré-Capitalistas, p. 85). 
Marx chega a se referir ao ponto de vista do indivíduo isolado como um modo de ver estúpido. Segundo Marx, a sociedade, no sentido de vida em conjunto com outros homens, é dada naturalmente, de modo nenhum politicamente. Sendo assim, como ressaltou Marx na Introdução de 1857, o homem só é um zoon politikon no sentido literal do termo, ou seja, no sentido de animal social, no sentido de que o homem é dado naturalmente em conjunto com outros homens. Porém, de maneira nenhuma, no sentido político do termo. Como enfatiza Marx nessa passagem dos Grundrisse:

\begin{abstract}
"Naturalmente, é fácil imaginar uma pessoa poderosa, fisicamente superior, que primeiro captura animais e depois captura homens para fazêlos apanhar mais animais para si. Em suma, alguém que use os homens como uma condição natural preexistente de sua reprodução, como qualquer outro ser da natureza; seu próprio trabalho esgota-se no ato de dominação. Mas este modo de ver é estúpido, embora possa ser correto do ponto de vista de uma dada entidade tribal ou comuna, pois toma o homem isolado como ponto de partida. O homem só é individualizado, porém, mediante o processo histórico. Originalmente, ele se mostra como um ser genérico, um ser tribal, um animal de rebanho - embora, de modo algum, como um 'animal político' no sentido político do termo" (Formações Econômicas Pré-Capitalistas, p. 90).
\end{abstract}

\title{
1.2. Crítica da ideologia política
}

Já na Questão Judaica encontramos a crítica explícita de Marx aos limites da compreensão dos revolucionários franceses, que depois se desdobra consideravelmente nas Glosas de 1844, com a crítica do "entendimento político" ou "ponto de vista político", e também na Sagrada Família, com a crítica da "superstição política" e da "ilusão gigantesca dos terroristas revolucionários". Na Ideologia Alemã, Marx apresenta novos elementos para essa crítica, que agora se volta contra a "ideologia política", a "ilusão política", ou "as ilusões dos juristas, dos políticos (incluindo entre estes os estadistas práticos)".

Como vimos no primeiro capítulo, o foco principal da Ideologia Alemã é a crítica dos filósofos neo-hegelianos, chamados por Marx ao longo do texto de ideólogos. Os ideólogos são aqueles que compartilham de um modo de pensar idealista, que inverte as relações reais. Além dos filósofos neo-hegelianos, há uma outra categoria particular de ideólogos, 
que também é um alvo fundamental da crítica de Marx: os juristas e os políticos (incluindo os estadistas práticos).

Se o idealismo filosófico é característico dos "alemães", a ideologia política é própria aos "ingleses e franceses". Tanto os alemães quanto os ingleses e franceses são ideólogos, porém cada um à sua maneira. Há pontos comuns, mas sempre com suas particularidades. Em algumas passagens da Ideologia Alemã, ainda que por vezes de maneira implícita, Marx compara essas duas correntes de pensamento que são, simultaneamente, alvo de sua crítica. O principal ponto comum é que ambas padecem da desconsideração da base real da vida humana, isto é, das condições materiais de existência, da produção material da vida. A particularidade é que, se os alemães omitem completamente essa base, os ingleses e franceses a consideram como algo secundário, sem qualquer conexão com o curso da história. De um modo ou de outro, o resultado é o mesmo:

\footnotetext{
"Toda concepção histórica, até o momento, ou tem omitido completamente esta base real da história, ou a tem considerado como algo secundário, sem qualquer conexão com o curso da história. Isto faz com que a história deva sempre ser escrita de acordo com um critério situado fora dela. A produção da vida real aparece como algo separado da vida comum, como algo extra e supraterrestre. Com isto, a relação dos homens com a natureza é excluída da história, o que engendra a oposição entre natureza e história" (Ideologia Alemã, p. 57).
}

Como vimos no primeiro capítulo, o ponto de partida de toda concepção histórica, para Marx, é o reconhecimento do processo real de produção da vida humana através da relação fundamental do homem com a natureza (atividade sensível, trabalho), que é uma relação necessariamente consciente e social. A sociedade civil, definida como a "organização social que se desenvolve imediatamente a partir da produção e do intercâmbio", surge como o cenário real da história, como a base real de todas as produções humanas, incluindo o Estado e todas as formas de consciência.

Os alemães, ao omitirem essa base real, reduziam a história a uma sucessão de ideias puras. Já os ingleses e franceses, presos à ideologia política, ao considerarem essa base apenas de maneira secundária e sem conexão com a história, acabavam por reduzir a história aos acontecimentos políticos destacados de sua base real. Nestas concepções, tanto as ideias quanto as ações políticas estão distorcidas ideologicamente, na medida em que 
estão destacadas de sua base real, entendidas como seres autônomos, com história própria. Nas palavras de Marx:

"Vê-se, já aqui, que esta sociedade civil é a verdadeira fonte, o verdadeiro cenário de toda a história, e quão absurda é a concepção histórica anterior que, negligenciando as relações reais, limitava-se às ações altissonantes dos príncipes e dos Estados" (Ideologia Alemã, p. 53).

$E$, mais à frente:

"Consequentemente, tal concepção apenas vê na história as ações políticas dos príncipes e do Estado, as lutas religiosas e as lutas teóricas em geral, e vê-se obrigada, especialmente, a compartilhar, em cada época histórica, $a$ ilusão desta época. Por exemplo, se uma época imagina ser determinada por motivos puramente 'políticos' ou 'religiosos', embora a 'política' e a 'religião' sejam apenas formas de seus motivos reais, então o historiador da época considerada aceita essa opinião. A 'imaginação', a 'representação', que esses homens determinados fizeram de sua práxis real transforma-se na única força determinante e ativa que domina e determina a práxis desses homens. Quando a forma tosca sob a qual se apresenta a divisão do trabalho entre os hindus e entre os egípcios suscita nesses povos um regime de castas próprio de seu Estado e de sua religião, o historiador crê que o regime de castas é a força que engendrou essa forma social tosca" (Ideologia Alemã, p. 57-58).

Até aqui, a comparação foi apenas implícita, priorizando o resultado comum a ambas, isto é, a desconsideração da base real da história. Porém, quando a comparação se torna explícita e o foco é ressaltar a diferença, Marx chega a afirmar uma certa superioridade dos ingleses e franceses e em relação aos alemães: segundo Marx, os ingleses e franceses estão mais próximos da realidade do que os alemães, já que os acontecimentos políticos - embora distorcidos ideologicamente, isto é, destacados de sua base real e entendidos de maneira autônoma - estão mais próximos da realidade do que os pensamentos puros. Nas palavras de Marx,

"Enquanto os franceses e os ingleses se atêm à ilusão política, que está certamente mais próxima da realidade, os alemães se movem na esfera do 'espírito puro' e fazem da ilusão religiosa a força motriz da história" (Ideologia Alemã, p. 58).

E, logo adiante: 
"A filosofia hegeliana da história é a última consequência, levada à sua 'expressão mais pura', de toda esta historiografia alemã, que não gira em torno de interesses reais, sequer de interesses políticos, mas em torno de pensamentos puros [...]" (Ideologia Alemã , p. 58).

Reforçando a mesma posição, Marx reconhece que, mesmo presos à ideologia política, os ingleses e franceses foram os primeiros a tentar dar uma base materialista para a história:

\begin{abstract}
"Embora não tenham percebido a conexão deste fato [produção dos meios de vida, produção da própria vida material] com a assim chamada história senão de maneira extremamente unilateral, sobretudo quando se mantinham presos à ideologia política, os franceses e os ingleses, mesmo assim, realizaram as primeiras tentativas para dar à historiografia uma base materialista, ao escreverem as primeiras histórias da sociedade civil, do comércio e da indústria" (Ideologia Alemã, p. 40).
\end{abstract}

Se a ideologia política já é uma grande inversão das determinações reais, Marx acusa os alemães de "idealizar a ideologia", distanciando-se ainda mais da realidade:

“Hegel idealizava a representação do Estado própria dos ideólogos políticos, os quais ainda partiam dos indivíduos particulares, embora somente da vontade desses indivíduos, e fazia dessa vontade comum a vontade absoluta" (Ideologia Alemã, v. II, p. 165).

No Segundo Rascunho da Guerra Civil na França, Marx critica os contrarrevolucionários-escravocratas-restauradores por se aterem à superfície política, ignorando o condicionamento das formas políticas por seus respectivos corpos sociais, ou seja, ignorando que as mudanças das formas políticas são apenas a expressão política das mudanças da sociedade:

"Seus olhos turvos veem somente a superfície política dos regimes mortos e eles sonham em ressuscitá-los colocando um Henrique $V$ ou o conde de Paris em seu topo. Eles não veem que os corpos sociais que engendraram essas superestruturas políticas não existem mais, que esses regimes só foram possíveis em fases passadas da sociedade francesa, sob condições agora superadas [...]. Eles não veem que os ciclos das formas políticas foram 
apenas a expressão política das mudanças reais pelas quais a sociedade passou" (Segundo Rascunho, p. 175, grifos meus).

O equívoco fundamental da "ilusão política" ou "ideologia política" é a inversão das determinações reais entre Estado e sociedade civil, a desconsideração da sociedade civil enquanto base real do Estado, o qual é entendido como ser autônomo e determinante. Vale acompanhar novamente as já citadas palavras de Marx:

\begin{abstract}
"Quando se reduzem estas trivialidades a seu conteúdo efetivo, expressam mais do que seus pregadores sabem, isto é, cada forma de produção cria suas próprias relações de direito, formas de governo, etc. A grosseria e a incompreensão consistem em não relacionar, senão fortuitamente, uns aos outros, em não enlaçar, senão como mera reflexão, elementos que se acham unidos organicamente." (Introdução de 1857, p. 7).
\end{abstract}

Uma vez rompido ideologicamente esse vínculo orgânico fundamental, torna-se inevitável identificar a política como categoria inerente à vida social ou, nas palavras de Marx, como parte integrante da vida social, como categoria eterna. Na Carta a Annenkov, com sua ironia costumeira, Marx acusa Proudhon de incorrer justamente neste erro fundamental - erro característico do político doutrinário:

“Em seu desejo de conciliar as contradições, o Sr. Proudhon elude a pergunta: se não deverá ser destruída a própria base dessas contradições. Parece-se em tudo ao político doutrinário, para quem o Rei, a Câmara dos Deputados e o Senado são como partes integrantes da vida social, como categorias eternas. Só que ele busca uma nova fórmula para equilibrar esses poderes, cujo equilíbrio consiste, precisamente, no movimento atual, em que um desses poderes tão logo é vencedor como escravo do outro. Assim, no século XVIII, uma multidão de cabeças medíocres dedicaram-se a buscar a verdadeira fórmula para equilibrar os estamentos sociais, a nobreza, o rei, os parlamentos etc., e um belo dia, perceberam que já não havia nem rei, nem parlamento, nem nobreza. $O$ verdadeiro equilíbrio nesse antagonismo era a derrocada de todas as relações sociais, que serviam de base a essas instituições feudais e ao antagonismo entre elas." (Carta a Annenkov, p. 180-181). 


\subsection{Crítica da ilusão jurídica}

Na Ideologia Alemã, no item "A relação do Estado e do Direito com a Propriedade" do capítulo I - Feuerbach e nos itens "I. O Direito" e "II. A Lei" do capítulo sobre Max Stirner, Marx apresenta uma crítica da "concepção idealista do Estado" (Ideologia Alemã, v. II, p. 143). Trata-se da denúncia da "ilusão jurídica que reduz o direito à mera vontade" (Ideologia Alemã, p. 99-100), da "ilusão dos juristas e dos políticos no que respeita à concepção da vontade soberana" (Ideologia Alemã, v. II, p. 138), da "ilusão política de um reino do belprazer, da vontade ideológica" (Ideologia Alemã, v. II, p. 144) ou, mais precisamente, a “ilusão de que a lei se baseia na vontade e, mais ainda, na vontade destacada de sua base real - na vontade livre" (Ideologia Alemã, p. 98).

Essas passagens da Ideologia Alemã representam uma continuação e um aprofundamento da crítica do "entendimento político" ou do "ponto de vista político" das Glosas de 1844. Nas Glosas, Marx afirmava que

"O entendimento político o é, precisamente porque pensa dentro dos limites da política. E, quanto mais vivo e sagaz seja, mais incapacitado se encontrará para compreender os males sociais". (Glosas de 1844, p. 514)

E já denunciava incisivamente a crença política na onipotência da vontade:

"O princípio da política é a vontade. Quanto mais unilateral e, portanto, mais perfeito seja o entendimento político, tanto mais acreditará na onipotência da vontade, tanto mais resistirá a ver as barreiras naturais e espirituais que se levantam diante dela, mais incapaz será, por conseguinte, de descobrir a fonte dos males sociais" (Glosas de 1844, p. 514).

Na Ideologia Alemã, Marx inicia sua crítica à "ilusão política" demonstrando a semelhança entre o procedimento do idealismo no âmbito filosófico e no âmbito político, ou seja, demonstrado que a "ilusão política" não passa de uma variante da ideologia - no sentido de inversão idealista das determinações reais -, ao lado da ideologia filosófica. Assim como os filósofos destacam o pensamento de sua base real - os indivíduos e suas condições materiais de existência - e chegam a uma história do pensamento puro, os políticos e juristas "arrancam o direito de sua base real" e chegam a uma "vontade soberana". Esta "vontade soberana", ou seja, esta vontade arrancada de sua base real, teria uma história 
própria objetivada nas leis. A história real, ao invés de reduzir-se ao domínio das ideias, como para os filósofos, reduz-se agora, na "ideologia política", ao domínio das leis sucessivas. Segundo Marx, "É esta a ilusão específica dos juristas e dos políticos":

\begin{abstract}
"Tivemos já ocasião de verificar como foi possível surgir entre os filósofos, pelo fato de separarem os pensamentos dos indivíduos das condições empíricas em que estes se baseiam, uma evolução e uma história do pensamento puro. Desta forma, é igualmente possível arrancar o direito da sua base real, dele extrair uma 'vontade soberana' que se modifica conforme as épocas e que possui nas suas criações, que são o conjunto das leis, a sua própria história autônoma. Deste modo, a história civil e política resolve-se ideologicamente numa história do domínio das leis sucessivas. É esta a ilusão específica dos juristas e dos políticos [...]" (Ideologia Alemã, v. II, p. 137).
\end{abstract}

Como vimos, a "ilusão jurídica e política" não é apenas um equívoco da consciência, mas uma determinação da própria realidade. Consequentemente, a crítica da "ilusão jurídica" não é apenas crítica de um modo equivocado de compreender a realidade, mas também e ao mesmo tempo crítica do direito enquanto tal.

No primeiro capítulo da Ideologia Alemã, no item "A relação do Estado e do Direito com a Propriedade", Marx considera mais de perto o direito privado e analisa a ilusão contida no jus utendi et abutendi (direito de usar e abusar), isto é, no direito de propriedade privada.

"No direito privado, as relações de propriedade existentes são declaradas como sendo resultado da vontade geral. O próprio jus utendi et abutendi exprime, de um lado, o fato de que a propriedade privada tornou-se completamente independente da comunidade e, de outro, a ilusão de que a própria propriedade privada repousa unicamente na vontade privada, na disposição arbitrária da coisa" (Ideologia Alemã, p. 100).

Segundo Marx, porém, embora de direito ele possa usar e abusar da sua propriedade, é preciso considerar que uma coisa só se torna uma verdadeira propriedade na relação prática do comércio, relação esta que é independente do direito. Nas palavras de Marx:

"Na prática, o abuti (o abusar) tem limites econômicos muito bem determinados para o proprietário privado, se este não quer que sua propriedade, e com ela seu jus abutendi (direito de abusar), passe para 
outras mãos, já que a coisa, considerada simplesmente em relação com a sua vontade, não é inteiramente uma coisa, mas apenas se torna uma coisa, uma verdadeira propriedade, no comércio e independentemente do direito (uma relação, a que os filósofos chamam de ideia)" (Ideologia Alemã, p. 100).

Mas a ilusão não existe somente na cabeça do proprietário privado ou dos juristas, ou seja, não se trata apenas de uma compreensão equivocada da realidade. A ilusão jurídica é antes uma ilusão inerente às relações da propriedade privada, uma vez que efetivamente é possível ter o título jurídico de alguma coisa, sem ter de fato esta coisa.

"Esta ilusão jurídica, que reduz o direito à mera vontade, conduz necessariamente, no desenvolvimento ulterior das relações de propriedade, ao resultado de que uma pessoa pode ter um título jurídico em relação a uma coisa sem realmente ter a coisa. Assim, por exemplo, se a renda de um lote de terra é suprimida pela concorrência, o proprietário do mesmo conserva, sem dúvida, seu título jurídico, bem como o jus utendi et abutendi. Mas nada poderá fazer como ele: nada possuirá enquanto proprietário de terra se não possuir também capital suficiente para cultivar seu lote" (Ideologia Alemã, p. 100).

O esforço de Marx, nessas passagens, é justamente mostrar que o direito provém e é determinado pelas relações de propriedade, que são relações objetivas e que não dependem unicamente do arbítrio privado. A redução do direito à mera vontade, chamada por Marx de "ilusão jurídica", é portanto um procedimento característico da ideologia, na medida em que inverte as relações reais, omitindo a base real do direito, que é tratado como se possuísse uma existência autônoma e determinante.

No capítulo da Ideologia Alemã sobre Max Stirner, Marx retoma e aprofunda alguns aspectos de sua crítica da "ilusão jurídica". De acordo com Marx, para Stirner "O direito não nasce das condições materiais em que vivem os homens nem tão-pouco dos conflitos que resultam delas, nasce sim do conflito que os opõe à representação que se veem obrigados 'a tirar das suas cabeças"” (Ideologia Alemã, v. II, p. 118). Por isso, "O que desejamos é que São Sancho se disponha a verificar em que medida o direito está associado à propriedade privada e implica, além disso, toda uma série de outras relações jurídicas [...]" (Ideologia Alemã, v. II, p. 118-119). Porém, “Como não se ocupa absolutamente nada do conteúdo do direito, já não 
falando em fazer-Ihe crítica, a única coisa que lhe resta, para fingir que está a falar dele, é conservar, pelo menos, a palavra" (Ideologia Alemã, v. II, p. 122).

\begin{abstract}
"Tal atitude evita-Ihe ter de saber alguma coisa sobre o modo de produção medieval, que tem como expressão política o privilégio, e sobre o modo de produção moderno, que tem como expressão o direito puro e simples, o direito igual, e, também, sobre as relações entre estes dois modos de produção e as relações jurídicas que Ihes correspondem" (Ideologia Alemã, v. II, p. 133).
\end{abstract}

Como vimos no capítulo anterior, Marx critica a corrente filosófica que fundamenta o direito na vontade e se insere na corrente que entende a força como o fundamento do direito, no sentido de que as relações jurídicas são "o sintoma, a expressão de outras relações sobre que repousam o poder do Estado". E isso, de uma forma "perfeitamente independente da vontade dos indivíduos". Como podemos verificar desde o início deste capítulo, a crítica à ilusão jurídica que reduz o direito à mera vontade consiste, essencialmente, na reafirmação do primeiro pressuposto da crítica de Marx à política: o Estado não existe de maneira autônoma, mas tem como base real a sociedade civil, ou seja, a vida material dos indivíduos, o seu modo de produção e as suas formas de intercâmbio; são essas relações materiais que criam o poder de Estado, e não o contrário. Vale retomar as próprias palavras de Marx:

\footnotetext{
"Na história real, os teóricos que têm tomado o poder como fundamento do direito opuseram-se diretamente àqueles que consideravam a vontade como base [...]. Se tornarmos o poder, a força, no fundamento do direito, tal como fizeram Hobbes e outros mais, então o direito, a lei, etc., apenas são o sintoma, a expressão de outras relações sobre que repousam o poder do Estado. A vida material dos indivíduos, que não depende de modo nenhum apenas da sua 'vontade', o seu modo de produção e as suas modalidades de troca, que se condicionam reciprocamente, são a base real do Estado e continuarão a sê-lo em todos os estádios em que sejam ainda necessárias a divisão do trabalho e a propriedade privada, de uma forma perfeitamente independente da vontade dos indivíduos. Estas condições reais não são, de modo algum, criadas pelo poder do Estado, pelo contrário, são elas que criam este poder" (Ideologia Alemã, v. II, p. 135).
}

Vemos que, além da reafirmação do ponto de partida da crítica de Marx à política, a crítica da "ilusão jurídica" envolve ao mesmo tempo a denúncia específica da transfiguração ideológica da vontade, que consiste no procedimento idealista de arrancar a vontade de sua 
base real. Por isso, Marx se vê obrigado a reafirmar a base real da vontade, ou seja, as circunstâncias materiais que determinam a vontade dos indivíduos.

Para Marx, é preciso examinar o que os indivíduos "fazem na realidade e o que, em determinadas circunstâncias, são compelidos a fazer" (Ideologia Alemã, v. II, p. 16). Ou seja, determinadas circunstâncias criam formas necessárias de afirmação dos indivíduos, as quais não dependem unicamente da sua vontade. Por exemplo, nas palavras de Marx, "o egoísmo, assim como o devotamento, é uma das formas e, em certas condições, uma forma necessária da afirmação dos indivíduos" (Ideologia Alemã, v. II, p. 17).

No caso da política, verifica-se a mesma determinação. Sob o domínio da propriedade privada e da divisão do trabalho, o Estado é uma forma necessária assumida pelo poder da classe dominante. Isso não depende nem da vontade dos indivíduos que exercem o poder, nem dos indivíduos que compõem as classes dominadas. Como vimos no capítulo anterior, as condições materiais fazem com que os indivíduos da classe dominante sejam compelidos a dar à sua vontade média a expressão geral de uma vontade de Estado, ou seja, de lei. A lei, para Marx, não passa da expressão da vontade dos indivíduos da classe dominante, vontade que é determinada por condições objetivas comuns a esta classe. Se na forma, a lei tem caráter geral, ou seja, é válida para todos independente do seu bel-prazer, no conteúdo, ela é a expressão da vontade média da classe dominante, ou seja, dos interesses comuns a essa classe, determinados pelas condições comuns em que vivem seus membros.

Sempre enfatizando a determinação da vontade dos indivíduos pelas suas condições materiais de existência, Marx reafirma que a lei é uma forma necessária de afirmação da vontade dos indivíduos da classe dominante, porém não da vontade de cada um tomado isoladamente, mas apenas enquanto vontade média, ou seja, enquanto expressão dos interesses comuns de sua classe, os quais são determinados por condições materiais efetivamente comuns:

"Não depende da sua vontade idealista, do seu bel-prazer, o fato de o seu corpo ter ou não ter peso; tão-pouco depende deles impor a sua própria vontade sob a forma de lei ou não, e simultaneamente, afirmá-la como sendo independente do bel-prazer pessoal de cada um deles considerado individualmente. O seu domínio pessoal tem apenas possibilidade de se constituir, simultaneamente, como domínio médio. O seu domínio pessoal assenta sobre condições de existência comuns a um grande número de 
entre eles, condições de que eles, os que ascenderam ao poder, têm de assegurar a persistência contra os outros modos de vida e que, além disso, terão de afirmar como válidas para a generalidade. A expressão desta vontade determinada pelos seus interesses comuns é a lei" (Ideologia Alemã, v. II, p. 136).

Para as classes dominadas, mantém-se a mesma determinação: não depende de sua vontade nem a existência e nem a superação do Estado e da lei. Ambas são determinadas pelas condições materiais da produção da vida humana. Para Marx, a própria "vontade" de superação do Estado e da lei só pode surgir quando as forças produtivas atingem um alto nível de desenvolvimento, que torna possível a superação real da concorrência, e de par com ela do Estado e da lei ${ }^{32}$. Ou seja, segundo Marx, há condições materiais no interior das quais pode surgir determinada vontade, a qual por isso mesmo não é arbitrária, mas socialmente determinada. Entretanto, uma vez dadas as condições materiais para o surgimento dessa vontade, os ideólogos a destacam de sua base real e a transformam assim numa vontade arbitrária, que pode ser estendida a qualquer momento histórico. Nas palavras de Marx:

\begin{abstract}
"O mesmo acontece no que respeita às classes dominadas: tão pouco depende da sua vontade o fato de existir a lei e o Estado. Enquanto as forças produtivas não tiverem atingido um ponto de desenvolvimento que torne supérflua a concorrência - outra coisa não fariam, portanto, senão fazer renascer a concorrência - para as classes dominadas seria aspirar ao impossível ter apenas a 'vontade' de abolir a concorrência, e de par com ela o Estado e a lei. De resto, esta 'vontade' não existe, antes de o desenvolvimento das condições sociais a poder produzir realmente, senão na imaginação dos ideólogos. Uma vez que as condições suscetíveis de a produzir estejam suficientemente desenvolvidas, o ideólogo pode considerar esta vontade como uma vontade puramente arbitrária e, assim, possível de conceber em todos os tempos e em todas as circunstâncias históricas" (Ideologia Alemã, v. II, p. 136-137)
\end{abstract}

Aqui, trata-se de ressaltar a crítica específica de Marx a essa "vontade arbitrária", também chamada de "vontade ideológica", "vontade soberana", "vontade livre" e "reino do bel-prazer", uma vez que ela constitui o fundamento da "ilusão específica dos juristas e dos políticos". A “ilusão jurídica" é também referida ironicamente por Marx como "a imaginação fantástica que leva a ver, no direito e na lei, o domínio exercido por uma vontade geral

\footnotetext{
32 O tema da superação do Estado será abordado mais detalhadamente no próximo capítulo, sobre a emancipação humana.
} 
autônoma" (Ideologia Alemã, v. II, p. 137). Contra a "ilusão dos juristas e políticos", Marx sustenta incansavelmente que tanto a vontade dos indivíduos quanto o Estado não podem ser considerados como seres autônomos, com bases próprias, que determinam as relações sociais; mas que, ao contrário, são ambos provenientes do modo de existência material dos indivíduos:

\footnotetext{
"Ora, o Estado não existe em virtude de uma vontade soberana, mas o Estado, proveniente do modo de existência material dos indivíduos, assume além do mais a forma de uma vontade soberana. Se esta vontade perde alguma vez o seu poder, tal fato não envolve somente mudança da vontade, mas também da existência material, da vida dos indivíduos, e a esta mudança se deve ter mudado a sua vontade" (Ideologia Alemã, v. II, p. 137).
}

Marx apresenta dois exemplos que corroboram a sua crítica à vontade soberana e ainda demonstram que ela atinge não apenas os teóricos, mas também os políticos e estadistas práticos. O primeiro exemplo é de Frederico Guilherme IV, rei da Prússia à época, que, assim como Max Stirner,

\begin{abstract}
"também considerava as leis como expressão pura e simples da vontade soberana, surpreendendo-se em seguida, pelo fato de elas fracassarem sempre quando aplicadas a 'essa espécie de matéria informe' que é o mundo. Ele que veja se algum dos seus inocentes caprichos pode alguma vez alcançar a eficácia de um despacho ministerial. Que decrete, pois, um empréstimo de 25 milhões, a centésima décima parte da dívida pública da Inglaterra, e verá de onde provém a vontade soberana" (Ideologia Alemã, v. II, p. 138).
\end{abstract}

O segundo exemplo se refere à relação entre o Estado e a pobreza. Diz Marx:

\begin{abstract}
"Uma análise, mesmo superficial, da legislação, por exemplo da legislação sobre a questão da pobreza, em todos os países, demonstrar-nos-ia o que sucedeu aos governantes sempre que supuseram poder impor esta ou aquela medida unicamente pela sua 'vontade soberana', ou seja, por simples imposição do seu querer" (Ideologia Alemã, v. II, p. 138).
\end{abstract}

Os dois exemplos evidenciam o fato de que a crítica de Marx não se dirige unicamente aos teóricos e aos ideólogos da política e do direito, mas, ao contrário, atinge igualmente a atuação política prática dos estadistas e dos revolucionários. E é justamente a 
crítica da ilusão política do ponto vista prático que será o objeto da segunda parte deste capítulo, a começar pela relação entre o Estado e os governantes, de um lado, e os problemas sociais, especificamente a pobreza, de outro, tema que constitui o mote das Glosas Críticas de 1844.

\section{Superstição política prática}

\subsection{A ilusão dos estadistas: a impotência do Estado frente aos males sociais}

As Glosas Críticas ao artigo "O Rei da Prússia e a Reforma Social. Por Um Prussiano", aqui referida simplesmente como Glosas de 1844 ou Glosas Críticas, constituem dois artigos escritos por Marx em julho de 1844, por ocasião das revoltas dos tecelões silesianos, e publicados em agosto do mesmo ano no periódico Vorwärtz ("Avante!"). Nesse texto, que marca sua ruptura definitiva com Arnold Ruge, neo-hegeliano com quem idealizou e publicou os Anais Franco-Alemães, Marx apresenta uma verdadeira crítica do entendimento político ou crítica do ponto de vista político.

O tema central das Glosas de 1844 é a relação do Estado e da política com os problemas sociais, especificamente o pauperismo (isto é, a miséria). E, como de costume, Marx parte dos fatos. Para se opor à visão de Ruge, começa descrevendo historicamente as diversas tentativas de acabar com o pauperismo na Inglaterra, país político por excelência. Em seguida, cita o exemplo de Napoleão e, por fim, da Convenção, que era "o expoente máximo da energia política, do poder político e da inteligência política" (Glosas Críticas, p. 512). Com isso, Marx encontra fatos que explicitam a relação entre a política na sua forma mais desenvolvida, teórica e praticamente, e os problemas sociais, o que the permite demonstrar que a incapacidade de compreender a raiz dos problemas sociais e de solucionálos praticamente não é resultado da imperfeição ou da insuficiência políticas do Estado prussiano, mas sim uma imperfeição inerente à política enquanto tal, imperfeição da sua própria natureza. E que, portanto, quanto mais perfeita a política, prática e teoricamente, mais incapaz será de compreender e solucionar os problemas sociais. 
Na Inglaterra, a primeira ação contra o pauperismo foi a caridade legal, através da taxa dos pobres. Em seguida, como continuava crescendo, o pauperismo foi atribuído a uma falha na legislação vigente: "o que antes se explicava por uma falta de caridade se interpretava agora como um excesso dela". Era necessário reformar a administração da taxa dos pobres. Por fim, o pauperismo passou a ser visto não como uma desgraça, mas como um delito, que deveria ser punido. Daí surgiram as workhouses, asilos em que, nas palavras sarcásticas de Marx, "se combina engenhosamente a beneficência com a vingança exercida pela burguesia contra os desgraçados que apelam para a sua caridade" (Glosas Críticas, p. 510).

Com isso, o pauperismo acabou se transformando em uma instituição nacional, extremamente extensa e complexa, uma espécie de Ministério do pauperismo, que "já não tem mais como finalidade acabar com ele, mas sim discipliná-lo e eternizá-lo" (Glosas Críticas, p. 511). E, quando começa a brotar na superfície da vida oficial, o Estado se limita a escondê-lo, com "suavidade policial".

Napoleão, por sua vez, encarregou as autoridades de elaborarem um plano para acabar com a mendicância em toda a França. Como o projeto demorou, Napoleão se cansou de esperar e deu o prazo de um mês. Como resultado, foi decretada a lei de repressão da mendicância, através dos depósitos, que eram postos de vigilância policial. Essa medida, porém, apenas serviu para esconder a pobreza.

Também a Convenção ordenou que se acabasse com o pauperismo.

"E qual foi a consequência do decreto ditado pela Convenção? Que houvesse no mundo mais um decreto e que um ano depois a Convenção estivesse sitiada por uma multidão de mulheres famintas" (Glosas Críticas, p. 512).

Depois de apresentados os fatos, ou seja, as tentativas dos Estados considerados politicamente mais fortes de acabar com a miséria, Marx pode concluir, contra Ruge:

"todos os Estados que se ocuparam do pauperismo se limitaram a aplicar medidas administrativas e de beneficência ou a descer abaixo desta classe de medidas" (Glosas Críticas, p. 512). 
Porém, continua Marx: “E pode o Estado proceder de outro modo?" (Glosas Críticas, p. 512). Com esta pergunta, Marx inicia a exposição das relações gerais entre a política e os problemas sociais. Essa exposição constitui ao mesmo tempo a crítica do ponto de vista político ou entendimento político.

O ponto de vista político ou entendimento político - que não se refere, nas Glosas, apenas aos teóricos, mas principalmente aos políticos práticos, tanto os estadistas, como o rei da Prússia e Napoleão, quanto os políticos revolucionários, como Robespierre e Saint-Just - reduz a organização social ao Estado. Assim, a raiz de todos os problemas sociais estaria no próprio Estado, ou seja, numa imperfeição sua, que deve ser corrigida - seja no partido que está no poder, na pessoa do governante ou numa determinada forma de governo:

\begin{abstract}
"Onde quer que existam partidos políticos, cada um deles encontra a razão de todo mal no fato de que não seja ele, mas seu concorrente, quem empunha o timão do Estado. Até os políticos radicais e revolucionários buscam a razão do mal, não na essência do Estado, mas em uma determinada forma de governo, que tratam de substituir por outra" (Glosas Críticas, p. 512-3).
\end{abstract}

Se as mudanças na esfera política não são suficientes para resolver os problemas sociais, então a causa é atribuída a uma lei natural, à vida privada ou à transgressão de seus fins pela administração:

\begin{abstract}
"Do ponto de vista político, o Estado e a organização da sociedade não são duas coisas distintas. O Estado é a organização da sociedade. Quando o Estado reconhece a existência de anomalias sociais, trata de encontrá-las ou em leis naturais, às quais nenhum poder humano pode fazer frente, ou na vida privada, independente dele, ou na transgressão de seus fins pela administração que dele depende" (Glosas Críticas, p. 513).
\end{abstract}

Do ponto de vista político, o Estado é a organização da sociedade. Isso significa que, segundo esse ponto de vista, as mudanças na organização social só podem ocorrer a partir da esfera política, ou seja, a solução dos problemas sociais está no aperfeiçoamento do Estado. Aquilo que foge à alçada do Estado é visto como algo natural, sobre o que a ação humana não tem poder algum. Por isso,

"todos os Estados buscam nos defeitos casuais ou intencionais da administração a causa de seus males e recorrem, portanto, a medidas 
administrativas para remediá-los. Por quê? Precisamente porque a administração é a atividade organizativa do Estado" (Glosas Críticas, p. 513).

Para Marx, entretanto, a raiz dos males sociais está fora do Estado, ou seja, na atual organização da sociedade. Estado e organização social, ao contrário do que afirma o ponto de vista político, são duas coisas distintas: a sociedade civil é o fundamento natural, o princípio, a essência do Estado; e o Estado é a expressão ativa, consciente de si mesma e oficial da sociedade civil. O entendimento político, justamente porque pensa dentro dos limites da política, reduzindo a organização social ao Estado, é incapaz de encontrar a raiz dos males sociais. Marx é categórico ao ressaltar os limites do entendimento político:

"Quando mais poderoso seja o Estado e quanto mais político seja, portanto, o país, menos se inclinará a buscar no princípio do Estado e, portanto, na atual organização da sociedade, cuja expressão ativa, consciente de si mesma e oficial é o Estado, o fundamento dos males sociais e a compreender seu princípio geral. O entendimento político é político precisamente porque pensa dentro dos limites da política. E, quanto mais vivo e sagaz seja, mais incapacitado se encontrará para compreender os males sociais" (Glosas Críticas, p. 514).

Para Marx, quanto mais perfeito, vivo e sagaz seja o entendimento político, mais limitado e unilateral, uma vez que ele se fundamenta na onipotência da vontade ${ }^{33}$ :

“O princípio da política é a vontade. Quanto mais unilateral e, portanto, mais perfeito seja o entendimento político, tanto mais acreditará na onipotência da vontade, tanto mais resistirá a ver as barreiras naturais e espirituais que se levantam diante dela, mais incapaz será, por conseguinte, de descobrir a fonte dos males sociais" (Glosas Críticas, p. 514).

Para Marx, porém, a vontade política possui limites objetivos. Não basta a disposição e a boa vontade da administração para resolver os problemas sociais. Ao contrário, para Marx, a administração é intrinsecamente impotente diante dos males sociais, uma vez que a raiz destes está na própria base do Estado: o Estado descansa justamente sobre os males sociais, isto é, sobre a atual organização social. Assim, o Estado só pode superar os

\footnotetext{
${ }^{33}$ Como vimos acima, essa determinação é posteriormente desdobrada na Ideologia Alemã, especialmente no capítulo contra Max Stirner, onde Marx apresenta sua crítica à vontade ideológica, isto é, à vontade arrancada de sua base real, entendida como fundamento da ilusão jurídica.
} 
problemas sociais destruindo seu próprio fundamento e, portanto, destruindo-se a si mesmo. Diz Marx:

\begin{abstract}
"O Estado não pode superar a contradição entre a disposição e a boa vontade da administração, de um lado, e de outra seus meios e sua capacidade sem destruir-se a si mesmo, já que descansa sobre esta mesma contradição. Descansa sobre a contradição entre a vida pública e a vida privada, sobre a contradição entre os interesses gerais e os interesses particulares. Daí que a administração deva limitar-se a uma atividade formal e negativa, pois sua ação termina ali onde começa a vida civil e seu trabalho. Mais ainda, frente às consequências que se derivam do caráter anti-social desta vida civil, desta propriedade privada, deste comércio e desta indústria, deste mútuo saqueio dos diversos círculos da sociedade civil, é a impotência a lei natural da administração" (Glosas Críticas, p. 513).
\end{abstract}

Segundo Marx, o Estado não é um ser autônomo, com bases próprias; ao contrário, é produto de uma organização social limitada e contraditória. Longe de ser visto como a esfera da liberdade, o Estado é denunciado por Marx como um produto da escravidão, isto é, da ausência de liberdade. Vale retomar as incisivas palavras de Marx:

\begin{abstract}
"Com efeito, essa dilaceração, esta infâmia, esta escravidão da sociedade civil, constitui o fundamento natural em que se baseia o Estado moderno, assim como a sociedade civil da escravidão constituía o fundamento sobre o qual descansava o Estado antigo. A existência do Estado e a existência da escravidão são inseparáveis. O Estado antigo e a escravidão antiga - francos e sinceros antagonismos clássicos - não se encontravam fundidos entre si mais estreitamente do que o Estado moderno e o moderno mundo das trocas, hipócritas antagonismos cristãos" (Glosas Críticas, p. 513).
\end{abstract}

Para superar a sua impotência diante dos males sociais, o Estado teria que acabar com o seu próprio fundamento. E, acabando com seu fundamento, ele mesmo iria pelos ares. Porém, como "o suicídio é contrário à natureza", o Estado não pode acreditar que sua impotência lhe seja intrínseca. Se não consegue resolver algum problema, este é atribuído a uma lei natural ou divina, ou à vontade corrompida dos particulares. Isso significa que o entendimento político não pode ser visto como um simples equívoco da subjetividade, mas sim como um produto da limitação objetiva da própria esfera política. Diz Marx:

"Se o Estado moderno quisesse acabar com a impotência de sua administração, teria que acabar com a atual vida privada. E, se quisesse acabar com a vida privada, teria que destruir-se a si mesmo, pois o Estado 
só existe por oposição a ela. Mas nenhum ser vivo crê que os defeitos de sua existência radiquem no princípio de sua vida, na essência de sua vida, mas sim em circunstâncias exteriores a ela. O suicídio é contrário à natureza. Daí que o Estado não possa crer na impotência interior de sua administração, ou seja, na sua própria impotência. Só pode reconhecer e tratar de corrigir seus defeitos puramente formais e fortuitos. E, se estas modificações resultam ser estéreis, concluirá que os males sociais são uma imperfeição natural, independente do homem, uma lei de Deus, ou que a vontade dos particulares está demasiado corrompida para acomodar-se aos excelentes fins da administração" (Glosas Críticas, p. 513-4).

\subsection{A ilusão gigantesca do terrorismo revolucionário francês}

Embora o Estado se erga sobre a base da sociedade burguesa e embora ele tenha como objetivo justamente para a sua garantia, Marx reconhece que há momentos particulares em que o Estado age de um modo bem diferente: ao invés de aceitar tacitamente seus pressupostos e deixá-los agir da sua maneira particular na sociedade civil, o Estado procura abafá-los com todos os seus meios. Nesses momentos, nas palavras de Marx, o Estado procura se impor como a "genuína e harmoniosa vida genérica do homem", o que só pode fazer através da supressão violenta de seus próprios pressupostos, ou seja, da sociedade civil e seus elementos. Porém, segundo Marx, por mais que haja vontade política e por mais que se utilizem os meios mais violentos, por mais que a vida política queira se impor como a "genuína e harmoniosa vida genérica do homem", o "drama político" termina necessariamente com a restauração dos elementos que buscava suprimir, uma vez que a sociedade civil e seus elementos constituem de fato as condições de existência, isto é, os pressupostos sobre os quais se ergue a vida política, o Estado. Com isso, Marx não apenas indica as trágicas consequências da tentativa de realizar a autolibertação do homem sob a forma da emancipação política, como também reafirma sua posição segundo a qual a emancipação política é incapaz de realizar a emancipação real do homem. Nas palavras de Marx:

"Sem dúvida, nos períodos em que o Estado político como tal nasce violentamente na sociedade civil, em que a autolibertação humana procura realizar-se sob a forma da auto-emancipação política, o Estado pode e deve prosseguir na abolição e na destruição da religião; mas só da maneira como realiza a abolição da propriedade privada, pela declaração de um máximo, 
por confiscação ou por taxação progressiva, ou da maneira como decide abolir a vida, por meio da guilhotina. Nos momentos de seu especial amor próprio [Selbstgefühl], a vida política procura abafar os próprios pressupostos - a sociedade civil e seus elementos - e estabelecer-se como a genuína e harmoniosa vida genérica do homem. Mas só conseguirá isso através da contradição violenta com as próprias condições de existência, declarando a revolução como permanente. Assim, o drama político termina necessariamente com a restauração da religião, da propriedade privada, de todos os elementos da sociedade civil, tal como a guerra termina com a paz" (Questão Judaica, p. 48).

Nesta passagem, está condensada o fundamento da crítica de Marx à emancipação política. O Estado possui pressupostos, que são verdadeiras condições de existência para ele, sua base real. Essa base real é constituída pela sociedade civil e seus elementos. Isso significa, antes de tudo, que o Estado não é um ente autônomo, mas ao contrário possui uma base real e só pode ser corretamente compreendido na sua determinação por ela. Com isso, Marx denuncia o fato de que o Estado é indissociável de todos os elementos alienados da sociedade civil, ou seja, de todos os "constrangimentos seculares" da "ordem mundana existente" - em especial, da propriedade privada, do dinheiro e da troca, apresentados na Questão Judaica como a base da sociedade civil.

O que aqui aparece apenas como característica dos momentos de "especial amor próprio" da vida política, dos momentos em que o Estado nasce violentamente da sociedade civil, ou seja, dos momentos revolucionários, será nas Glosas Críticas denunciado como característica geral do ponto de vista político, tanto teórico quanto prático, como vimos acima. O equívoco fundamental desta posição seria considerar o Estado como independente da sociedade civil, ou seja, partir do Estado como se ele tivesse bases próprias e como se ele fosse capaz de superar as contradições da sociedade civil, quando na verdade ele se funda sobre essas contradições a tal ponto de elas serem verdadeiras condições de existência para ele.

O Estado e a vida política em geral surgem no texto de Marx não como esfera independente, responsável pela organização ou desorganização da sociedade; ele também não aparece como o local e nem como o agente da autolibertação do homem. Ao contrário, o Estado político, inclusive e especialmente na sua forma mais desenvolvida, a democracia, aparece como um constrangimento, um dos elementos alienados da organização da nossa sociedade que, por isso mesmo, não apenas é incapaz de realizar a emancipação real do 
homem, como, mais ainda, precisa necessariamente ser superado para que seja possível alcançá-la.

Na Sagrada Família, Marx retoma e aprofunda essa crítica aos revolucionários franceses, ou seja, a ilusão gigantesca dos terroristas - que é como Marx designa Robespierre, Saint-Just e seu partido. Segundo Marx, a ilusão dos terroristas é a de ter tentado sacrificar a moderna sociedade burguesa a uma vida política antiga e, portanto, de ter tentado estabelecer um Estado democrático antigo sobre relações sociais e econômicas que já não eram mais as da Antiguidade. Isso gerou a contradição violenta entre o Estado e seus pressupostos reais, manifesta na contradição entre os direitos do homem solenemente proclamados e a sua supressão na prática. Nas palavras de Marx:

\begin{abstract}
"Robespierre, Saint-Just e seu partido sucumbiram por terem confundido antiga comunidade realista-democrática, baseada na real escravidão, com o moderno Estado representativo espiritualista-democrático, que descansa sobre a escravidão emancipada, sobre a sociedade burguesa. Que ilusão gigantesca ter de reconhecer e sancionar nos direitos humanos a moderna sociedade burguesa, a sociedade da indústria, da concorrência geral, dos interesses privados que perseguem com liberdade seus próprios fins, da anarquia, da individualidade natural e espiritual alienada de si mesma e, ao mesmo tempo, anular a posteriori em alguns indivíduos concretos as manifestações de vida dessa sociedade, e ao mesmo tempo formar a cabeça política dessa sociedade à maneira antiga!"

"Parece trágica essa ilusão, quando Saint-Just, no dia de sua execução, apontando para a grande tabela pendurada na sala da Conciergerie, exclama com orgulhoso amor-próprio: 'C'est pourtant moi que ai fait cela' ${ }^{34} \mathrm{E}$ justo aquela tabela proclamava o direito de um homem, que já não pode ser o homem da comunidade antiga, do mesmo modo que suas relações econômicas e industriais já não são as da Antiguidade" (Sagrada Familia, p. 141).
\end{abstract}

Napoleão, segundo Marx, significa a última batalha do terrorismo revolucionário contra a sociedade burguesa. Porém, não se trata mais de um terrorismo fanático $e$ sonhador, como o de Robespierre e Saint-Just, pois Napoleão já compreende que o Estado moderno é baseado no movimento desenfreado da sociedade civil e se propõe a defender seus fundamentos. Porém, ainda é terrorista na medida em que considera o Estado como

\footnotetext{
34 "No entanto, fui eu que fiz isso."
} 
um fim em si mesmo e a sociedade civil como um subalterno seu, sem direito a ter vontade própria. Nas palavras de Marx:

\begin{abstract}
"Napoleão foi a última batalha do terrorismo revolucionário contra a sociedade burguesa, também proclamada pela Revolução, e sua política. É certo que Napoleão já possuía também o conhecimento da essência do Estado moderno, e compreendia que este tem como base o desenvolvimento desenfreado da sociedade burguesa, o livre jogo dos interesses privados etc. Ele decidiu-se a reconhecer esses fundamentos e a protegê-los. Não era nenhum terrorista fanático e sonhador. Porém, ao mesmo tempo, Napoleão seguia considerando o Estado como um fim em si e via na vida burguesa apenas um tesoureiro e um subalterno seu, que não tinha o direito de possuir uma vontade própria. E levou a cabo o terrorismo ao pôr no lugar da revolução permanente a guerra permanente. Satisfez até a saciedade o egoísmo do nacionalismo francês, mas reclamou também o sacrifício dos negócios, o desfrute, a riqueza etc. da burguesia, sempre que assim o exigisse a finalidade política da conquista. E, se reprimiu despoticamente o liberalismo da sociedade burguesa - o idealismo político de sua prática cotidiana -, não poupou também seus interesses materiais essenciais, o comércio e a indústria, quando estes se chocavam com seus interesses políticos" (Sagrada Família, p. 142).
\end{abstract}

\title{
2.3. Crítica do viés democrático: as ilusões do proletariado e da pequena-burguesia
}

A superstição política não é exclusividade das classes dominantes. Também a classe trabalhadora e a pequena-burguesia, enquanto classe intermediária, têm suas ilusões. Marx denuncia essas ilusões em diversas passagens de sua obra, mas especialmente nas Glosas Críticas e em suas análise sobre o 1848 francês, isto é, na Nova Gazeta Renana, nas Lutas de Classes na França e no 18 de Brumário.

Como vimos, a ilusão política é uma ilusão gerada pela realidade constantemente, dado que o Estado de fato se destaca da sociedade e se instaura ao lado e fora dela, como se fosse algo independente. Ele aparece de fato, na realidade, como a esfera responsável pela organização da vida social. Assim, os próprios trabalhadores, ao pensarem sob a forma política, compartilham da ilusão política e em suas revoltas confundem o alvo: ao invés de atuar na base da sociedade burguesa, na organização da propriedade, na reorganização da produção da vida material, se dirigem apenas contra suas formas políticas, contra uma determinada forma de Estado que querem substituir por outra. 
Assim, cometem um erro semelhante ao dos revolucionários franceses de 1789 , pois não entendem a base real dos problemas sociais, não entendem a indissociabilidade entre o Estado e a sociedade burguesa, portanto entre o Estado e os problemas sociais contra os quais se revolta, e acaba por desperdiçar suas energias em revoltas estéreis.

\begin{abstract}
"Quanto mais desenvolvido e generalizado se acha o entendimento político de um povo, mais o proletariado desperdiça suas energias - pelo menos, no começo do movimento - em revoltas incompreensíveis, estéreis e afogadas em sangue. Como pensa sob a forma política, vê o fundamento de todos os males na vontade e os meios para remediá-los na força e no derrocamento de uma determinada forma de governo. A prova disso a encontramos nas primeiras explosões do proletariado francês. Os operários de Lyon só acreditavam perseguir fins políticos, ser soldados da república, quando na realidade eram soldados do socialismo. [...] $O$ entendimento político não Ihes permitia ver claramente as raízes da penúria social, os impedia de penetrar em sua verdadeira finalidade: o entendimento político enganava, pois, seu instinto social" (Glosas Críticas, p. 518-519).
\end{abstract}

Nos textos sobre o 1848 francês, Marx se refere a uma variante específica da superstição política, a superstição democrática, também chamada de prisma democrático e viés democrático. Essa superstição, gestada pelos ideólogos da burguesia, mas assentada principalmente sobre a pequena-burguesia, é especialmente perversa para os trabalhadores, justamente na medida em que quebra a ponta revolucionária de suas reivindicações, fazendo com que sua luta não se dirija mais à superação do conflito entre trabalho assalariado e capital, mas apenas à sua atenuação, em busca de uma piedosa e ilusória harmonia.

Nas Lutas de Classes na França, Marx se refere a uma das mais caras flores da superstição democrática, que embriagou os operários franceses em fevereiro de 1848: a fraternidade. Esta ilusão poderosa, que se fundamenta na abstração dos antagonismos de classe, atinge não apenas os operários, mas também as diversas camadas da classe dominante. A fraternidade é talvez a ilusão republicana por excelência, porque, ao anular a existência das classes, faz com que a república apareça como o governo de todos, e não apenas de uma classe, a burguesia. Segundo esta ilusão, as classes estariam dividas apenas por um mal-entendido. Acompanhemos as palavras de Marx, com seu costumeiro sarcasmo:

"Na ideia dos proletários, que confundiam a aristocracia financeira com a burguesia em geral; na imaginação pedante dos republicanos bem- 
pensantes, que negavam a própria existência das classes ou, quando muito, a admitiam como consequência da monarquia constitucional; na fraseologia hipócrita das frações burguesas até esse momento excluídas do poder fora abolida a dominação da burguesia com a instauração da República. Todos os realistas [Royalisten] se converteram então em republicanos e todos os milionários de Paris em operários. A frase que correspondia a esta imaginária abolição das relações entre classes era fraternité, a fraternidade universal, o amor entre irmãos. Esta cômoda abstração dos antagonismos de classes, esta conciliação sentimental dos interesses de classe contraditórios, esta visionária elevação acima da luta de classes, a fraternité era na verdade a palavra-chave da revolução de Fevereiro. As classes estavam divididas por um simples mal-entendido. Em 24 de fevereiro, Lamartine batizou assim o Governo provisório: 'un gouvernment qui suspend ce malentendu terrible qui existe entre les differentes classes'. O proletariado de Paris regalou-se nesta generosa embriaguez de fraternidade." (As Lutas de Classes na França, p. 219-220).

Na Nova Gazeta Renana, Marx é ainda mais incisivo:

\begin{abstract}
"A Fraternité, a fraternidade das classes antagônicas, uma das quais explora a outra, esta Fraternité proclamada em fevereiro, escrita com grandes letras maiúsculas na testa de Paris, em todas as prisões, em todas as casernas - sua expressão verdadeira, não falsificada, sua expressão prosaica é a guerra civil, a guerra civil em sua figura mais terrível, a guerra do trabalho contra o capital. Esta fraternidade chamejava diante de todas as janelas de Paris na noite de 25 de junho e iluminava a Paris da burguesia, enquanto a Paris do proletariado queimava, sangrava, agonizava. A fraternidade durou enquanto o interesse da burguesia esteve irmanado ao interesse do proletariado. [...] 0 que ele odiava instintivamente em Luís Filipe não era Luís Filipe, mas sim a dominação coroada de uma classe, o capital no trono. Mas, generoso como sempre, julgou ter aniquilado seu inimigo uma vez que derrubara o inimigo de seu inimigo, o inimigo comum" (Nova Gazeta Renana, p. 126-127, n. 29).
\end{abstract}

Apenas uma observação antes de prosseguir. A ilusão da fraternidade, assim como todas as ilusões políticas em geral, não é um simples erro do entendimento. Trata-se de uma ilusão gerada constantemente pela realidade, que tem como fundamento a relação de troca de mercadorias, que gera a aparência de igualdade entre todos, na medida em que realiza efetivamente essa igualdade formal. Porém, em fevereiro de 1848, há ainda um agravante: o antagonismo entre a burguesia e o proletariado ainda não estava completamente desenvolvido. Só a partir de fevereiro é que a dominação política da burguesia se consolida e o proletariado passa então de aliado a inimigo expressamente declarado, o que culmina nas jornadas de junho. Essa ilusão, portanto, nesse contexto específico, possui uma 
determinação social bem evidente. Como fica claro na comparação que Marx faz entre a revolução de fevereiro e a de junho:

"A revolução de fevereiro foi a bela revolução, a revolução da simpatia geral, porque os antagonismos que eclodiram nela contra a realeza, não desenvolvidos, dormitavam em comum acordo um ao lado do outro, porque a luta social que constituía seu fundamento alcançara apenas uma existência etérea, a existência de uma frase, da palavra. A revolução de junho é a revolução odiosa, a revolução repulsiva, porque o fato ocupou o lugar da frase, porque a república desnudou a própria cabeça do monstro, ao derrubar-Ihe a coroa protetora e dissimuladora" (Nova Gazeta Renana, p. 127, n. 29)

Ao longo de toda Nova Gazeta Renana, Marx ironiza diversas flores da fantasia popular que, ao lado na fraternidade, compõem essa variante específica da superstição política, que é a superstição democrática. Desde os primeiros artigos, Marx é explícito em sua recusa dos chamados esforços democráticos, que visam o bem-estar do povo, a felicidade de todos sem distinção. Segundo Marx, para solucionar o conflito entre as classes, ao invés de mascará-lo com abstrações piedosas ou conciliações hipócritas, é preciso ao contrário explicitá-lo na luta efetiva:

\begin{abstract}
"Importa-nos que o partido democrático tome consciência de sua situação. Perguntarão por que nos voltamos para um partido ${ }^{35}$, por que não temos em vista preferencialmente o objetivo dos esforços democráticos, o bemestar do povo, a felicidade de todos sem distinção? Tal é o direito e o hábito da luta, e apenas da luta dos partidos pode resultar a felicidade do novo tempo, não de compromissos aparentemente sagazes, de uma hipócrita aliança entre opiniões, interesses e fins antagônicos" (Nova Gazeta Renana, p. 82, n. 2).
\end{abstract}

Outra flor da fantasia democrática desmistificada especificamente por Marx é o sufrágio universal e, consequentemente, a própria ideia de povo. Mais uma vez, trata-se de demonstrar que o povo, longe de ser uma massa homogênea, na realidade é formado por

\footnotetext{
${ }^{35}$ Observe-se que a palavra partido, aqui, como ao longo de toda a obra de Marx, inclusive no Manifesto do Partido Comunista, não tem o sentido de partido político formalmente instituído e organizado, como foi disseminado a partir de Lenin e da Revolução Russa, e nem o sentido de partidos políticos tal como existem atualmente. Ao contrário, em Marx, partido se refere a uma posição determinada no conflito social entre as classes. Daí Marx opor, nesta passagem, o partido aos esforços democráticos, ao bem-estar do povo e à felicidade de todos sem distinção: o partido se refere a uma parte do povo, e não ao povo como um todo, essa abstração típica da superstição democrática.
} 
diferentes classes sociais que possuem interesses contraditórios e inconciliáveis. É nesse contexto que Marx desmistifica a ideia tão cara à tradição do pensamento político moderno de vontade de povo ou vontade da maioria. Como acontece em todo a sua obra, e como temos visto especialmente neste capítulo, o esforço de Marx está em demonstrar que a vontade não pode ser arrancada de sua base real e que, portanto, a vontade de um indivíduo é condicionada pela sua posição social e pelas suas condições de existência. Acompanhemos na íntegra a argumentação de Marx, voltada contra um artigo da Gazeta Nacional:

"O sufrágio universal, diz ela, nos deve desvendar qual é a vontade, não de um estamento ou classe singular, mas de todo o povo.

Muito bem! E de que consiste 'todo o povo'?

De 'estamentos e classes singulares'.

E de que consiste 'a vontade de todo o povo'?

Das 'vontades' singulares e mutuamente contraditórias de 'estamentos e classes singulares', portanto, exatamente da vontade que a Gazeta Nacional apresenta como a direta contraposição da 'vontade de todo o povo'.

Grande lógica, a da Gazeta Nacional!

Mas para a Gazeta Nacional existe uma vontade de todo o povo, que não é a soma de vontades contraditórias, mas sim uma vontade única, determinada. Qual?

É a vontade da maioria.

E o que é a vontade da maioria?

É a vontade que resulta dos interesses, da posição social, das condições de existência da maioria.

Portanto, para se ter uma única e mesma vontade, os membros da maioria devem ter os mesmos interesses, a mesma posição social, as mesmas condições de existência ou estar ainda provisoriamente encadeados a seus interesses, a sua posição social, a suas condições de existência.

Em termos claros: a vontade do povo, a vontade da maioria, é a vontade não de estamentos ou classes singulares, mas sim de uma única classe e daquelas outras classes e frações de classe que são socialmente, isto é, industrial e comercialmente, subordinadas àquela classe dominante.

'Mas o que queremos dizer com isso?' A vontade de todo o povo é a vontade de uma classe dominante?

Certamente, e o próprio sufrágio universal é a agulha magnética que, embora só após diversas oscilações, finalmente aponta para a classe chamada a dominar.

E esta boa Gazeta Renana ainda fantasia, como acontecia em 1847, com uma imaginária 'vontade de todo o povo'!" (Nova Gazeta Renana, p. 397398, n. 205). 
Nas Lutas de Classes na França, Marx retoma o tema do sufrágio universal, demonstrando a mesma ideia de uma outra maneira: na sociedade capitalista, o sufrágio universal só é autorizado na medida em que traduz a vontade da burguesia e, portanto, em que ratifique a sua dominação enquanto classe. A partir do momento em que ele a contradiz, deve ser suprimido:

"O domínio burguês como efluente e resultado do sufrágio universal, como ato declarado da vontade soberana do povo: esse é o sentido da Constituição burguesa. Porém, a partir do momento em que o teor desse sufrágio, dessa vontade soberana, não é mais a dominação dos burgueses, que sentido ainda teria a Constituição? Não seria dever da burguesia regulamentar esse sufrágio de tal maneira que ele queira o que é razoável, isto é, a sua dominação?" (As Lutas de Classes na França, Boitempo, p. 143).

No 18 de Brumário, Marx retoma e aprofunda essa crítica do viés democrático, especialmente na sua crítica da social-democracia francesa recém-nascida, começando por caracterizar o fundamento social real do prisma democrático, isto é, a pequena-burguesia.

"Porém, por representar a pequena burguesia, ou seja, uma classe de transição, na qual os interesses de duas classes se embotam de uma só vez, o democrata tem a presunção de se encontrar acima de toda e qualquer contradição de classe. Os democratas admitem que o seu confronto é com uma classe privilegiada, mas pensam que eles é que constituem o povo junto com todo o entorno restante da nação, que eles representam o direito do povo, que o seu interesse é o interesse do povo." (18 de Brumário, p. 67-68).

E, assim como os operários citados nas Glosas Críticas, limitados pelo entendimento político, os pequenos-burgueses atribuem qualquer falha na sua ação a motivos exteriores e particulares, mas nunca ao seu velho ponto de vista, ou seja, em resumo, a democracia permanece como um valor sagrado universal, apenas as condições exteriores é que não estariam maduras o suficiente para a sua realização efetiva. Nas palavras de Marx:

"Mas quando, no momento da ação concreta, os seus interesses se revelam desinteressantes e o seu poder se revela impotente, atribuem esse fato ou a sofistas perniciosos que dividem o povo indivisivel em diversas frentes hostis ou ao exército que estava por demais abestalhado e ofuscado para compreender os fins puros da democracia como a melhor coisa para si mesmo, ou tudo falhou em algum detalhe de execução ou então algum imprevisto pôs a perder essa rodada do jogo. Como quer que seja, o 
democrata sai da derrota mais vergonhosa tão imaculado quanto era inocente ao nela entrar, agora renovado em sua convicção de que ele deverá triunfar, não de tal modo que ele próprio e o seu partido tenham de renunciar ao seu velho ponto de vista, mas, ao contrário, de tal modo que as condições amadureçam no sentido por ele pretendido" (18 de Brumário, p. 67-68).

Essa crítica fica ainda mais explícita quando Marx aborda o Partido Social-Democrata, surgido logo após as jornadas de 1848 na França, de uma aliança entre os trabalhadores e a pequena-burguesia. Nessa caracterização, Marx evidencia nitidamente como os interesses dos trabalhadores, isto é, suas exigências revolucionárias, restam substancialmente limitados pelo viés democrático.

\footnotetext{
"Para enfrentar a burguesia coligada, formara-se uma coalizão de pequenoburgueses e trabalhadores, o chamado Partido Social-Democrata. [...] Um programa comum foi elaborado, comitês eleitorais comuns foram instituídos e candidatos comuns lançados. A ponta revolucionária das exigências sociais do proletariado foi quebrada e foi-lhe dado um viés democrático, as reivindicações democráticas da pequena-burguesia foram despidas de sua forma meramente política e a sua ponta socialista voltada para fora. Assim surgiu a social-democracia" (18 de Brumário, p. 62-63).
}

Marx é categórico: a ponta revolucionária das exigências sociais foi quebrada pelo viés democrático. Assim como em outros momentos de sua obra, o ponto de vista democrático aparece aqui em oposição frontal ao ponto de vista revolucionário. Do outro lado, para que as reivindicações democráticas da pequena-burguesia adquiram uma ponta socialista, é preciso que se dispam de sua forma meramente política. Porém, ainda que essas reivindicações democráticas pudessem incomodar e tenham de fato incomodado a dominação da burguesia, Marx demonstra que a social-democracia não poderia nunca transpor os limites da própria pequena-burguesia e, portanto, os limites do viés democrático. Ou seja, ainda que apareça vestida de cores revolucionárias mais ou menos intensas, a social-democracia não passa de uma ilusória tentativa de atenuar o conflito estrutural entre capital e trabalho assalariado, propondo uma piedosa harmonia.

"O caráter peculiar da social-democracia se resumia aos seguintes termos: reivindicavam-se instituições republicanas democráticas, não como meio de suprimir dois extremos, o capital e o trabalho assalariado, mas como meio de atenuar a sua contradição e transformá-la em harmonia. Quaisquer que sejam as medidas propostas para alcançar esse propósito, por mais que ele 
seja ornado com concepções mais ou menos revolucionárias, o teor permanece o mesmo. Esse teor é a modificação da sociedade pela via democrática, desde que seja uma modificação dentro dos limites da pequena-burguesia." (18 de Brumário, p. 63).

Em outra passagem, Marx repreende severamente os democratas, justamente por canalizarem a energia revolucionária das massas para o jogo eleitoral, ao invés de as levarem ao enfrentamento direto:

"em vez de forçar o adversário à luta no momento do entusiasmo popular e na disposição favorável das Forças Armadas, o partido democrata estafou Paris durante os meses de março e abril com uma nova agitação eleitoral, fez com que as paixões populares em polvorosa se desgastassem nesse renovado jogo provisório de votos, com que a energia revolucionária se saciasse com êxitos constitucionais e se queimasse em intrigas menores, declamações vazias e movimentos ilusórios [...]”" (18 de Brumário, p. 84).

E, logo à frente:

"Na mesma medida em que os democratas se exaltaram e vociferaram em termos revolucionários durante a campanha eleitoral constitucional, eles passaram a pregar em termos constitucionais; quando teria sido preciso comprovar com as armas na mão a seriedade daquelas vitórias eleitorais, eles passaram a pregar ordem, calma majestosa (calme mafesteueux), postura legal, isto é, submissão cega à vontade da contrarrevolução, que se disseminava em forma de lei." (18 de Brumário, p. 85).

\section{Fechamento}

A crítica da superstição política, como pudemos perceber, é antes de tudo a reafirmação do ponto de partida fundamental de toda a crítica de Marx à política, ou seja, a reafirmação de que a política não pode ser compreendida a partir de si mesma, mas apenas a partir de sua base real, ou seja, das relações sociais que conformam uma determinada maneira de produzir a vida material. Trata-se, portanto, de sempre demonstrar a determinação efetiva entre os elementos da relação, que na superstição política aparecem arbitrariamente invertidos ou ilusoriamente abstraídos. 
A superstição política reúne um conjunto de ilusões específicas, como por exemplo a onipotência da vontade, a crença no Estado e no direito como instrumentos de realização da liberdade humana, instrumentos neutros que podem ser infinitamente aperfeiçoados, a abstração ou distorção dos antagonismos estruturais da sociedade capitalista, a crença absoluta na democracia e nos direitos humanos como valores universais etc. Porém, sempre com o denominador comum de entender a esfera política como a esfera determinante, que teria poder de dar qualquer forma à sociedade, desde que houvesse vontade política para tanto. Essas ilusões são compartilhadas em maior ou menor grau tanto pelos teóricos da política, incluindo os filósofos, os cientistas políticos e os juristas, quanto pelos políticos práticos, o que inclui os estadistas, como Napoleão e Federico Guilherme IV, os revolucionários de 1789, assim como os próprios levantes operários. Afinal, como vimos, não se trata de um simples erro individual de compreensão, mas sim de ilusões geradas constantemente pela própria realidade.

Toda a análise de Marx a esse respeito apenas reitera e aprofunda a ideia de que o Estado e o direito são verdadeiros obstáculos, que se opõem frontalmente à realização da liberdade humana. E hoje, mais do nunca, a ruptura dessas ilusões, na teoria e na prática, é a condição imprescindível para o questionamento efetivo e radical da sociedade capitalista. A crítica da superstição política, que hoje embriaga a quase totalidade dos grupos sociais, é o ponto de partida para a reafirmação da necessidade da revolução social como único meio capaz de superar as contradições da sociedade capitalista. 


\section{POLÍTICA E EMANCIPAÇÃO HUMANA}

Neste capítulo, será analisado o modo como Marx compreende a emancipação humana. O capítulo será divido em duas grandes partes: uma sobre a emancipação em geral e outra sobre a emancipação humana especificamente no que diz respeito à sua relação com a política.

A primeira parte tomará como ponto de partida a análise do sentido geral da emancipação para Marx, enquanto restituição do mundo humano ao próprio homem. Em segundo lugar, a abolição da propriedade privada será apresentada como a condição fundamental para a emancipação humana e será desdobrada em alguns de seus aspectos mais concretos, como a socialização dos meios de produção e a consequente emancipação do trabalho, isto é, da atividade que é o fundamento de toda a existência humana. Esta socialização será identificada como a base da apropriação da totalidade das forças produtivas pelo conjunto dos indivíduos associados, apropriação esta que, por não se realizar somente no sentido do ter, implica o desenvolvimento de múltiplas capacidades humanas e, portanto, permite o desenvolvimento integral do indivíduo - sendo este o fim último da emancipação humana para Marx. Em terceiro lugar, serão analisadas as condições materiais da emancipação humana, que compreendem essencialmente um alto grau de desenvolvimento das forças produtivas, o desenvolvimento de uma classe revolucionária e uma revolução social radical. Neste contexto, será apresentada a crítica de Marx aos socialistas utópicos e será explicitado em que sentido Marx afirma que a emancipação humana assume a forma política da emancipação dos trabalhadores, ou seja, em que sentido os trabalhadores são os agentes da emancipação humana geral.

A segunda parte, voltada à emancipação humana especificamente em sua relação com a política, terá como ponto de partida a distinção entre revolução meramente política e revolução social radical, bem como a identificação da necessidade do momento político da revolução social, o momento de transição. Em segundo lugar, será desenvolvida a incompatibilidade que existe para Marx entre política e liberdade humana, a necessidade da extinção da política em geral, bem como o significado específico dessa extinção, ou seja, o fato de que o poder social, ao ser reabsorvido pela própria sociedade, perde o caráter 
político, e as funções públicas perdem o caráter de funções governamentais e se transformam em simples funções administrativas. Esse tema será desenvolvido particularmente nas análises de Marx sobre a Comuna de Paris. Com isso, retornamos à definição da Questão Judaica de emancipação humana, que tão bem sintetiza seu significado: reabsorção do cidadão abstrato pelo homem real e individual; transformação do indivíduo em verdadeiro ser genérico; reconhecimento de suas próprias forças - atualmente separadas de si enquanto força política - como forças sociais.

\section{Emancipação humana: significado geral e condições materiais}

Em seu significado mais geral, segundo Marx, emancipação significa a restituição do mundo humano e das relações humanas ao próprio homem.

"Toda emancipação constitui uma restituição do mundo humano e das relações humanas ao próprio homem." (Questão Judaica, p. 63)

Neste sentido, a emancipação é o antídoto da alienação. A alienação, definida como a prática da exteriorização, como a afirmação da essência humana através de um intermediário, e portanto de um ser estranho, é denunciada por Marx tanto na esfera da consciência e do sentimento, como vemos em sua crítica da filosofia especulativa, da religião e da moral, quanto na esfera da atividade prática, como vemos em sua crítica da política e da economia política.

\footnotetext{
"A exteriorização é a prática da alienação. Assim como o homem, enquanto permanece absorto na religião, só pode objetivar a sua essência através de um ser estranho e fantástico, assim sob a dominação da necessidade egoísta só pode afirmar-se a si mesmo e produzir objetos na prática, subordinando os produtos e a própria atividade ao domínio de uma entidade alheia, e atribuindo-Ihes o significado de uma entidade estranha, a saber, o dinheiro" (Questão Judaica, p. 73).
}

Nos Manuscritos de 1844, Marx concretiza significativamente essa definição, identificando a propriedade privada como a causa principal da alienação humana e, consequentemente, a sua abolição como a condição fundamental da emancipação. Todas as 
formas de alienação têm o seu fundamento na alienação prática, na alienação econômica, aqui traduzida por Marx como a propriedade privada.

"O comunismo é a abolição positiva da propriedade privada enquanto autoalienação humana e, deste modo, a real apropriação da essência humana pelo e para o homem. É, portanto, o retorno do homem a si mesmo como ser social, quer dizer, verdadeiramente humano, retorno esse pleno, consciente, que assimila toda a riqueza do desenvolvimento anterior" (Manuscritos de 1844, p. 192).

O comunismo é descrito como a emancipação do homem, ou seja, como a abolição de toda alienação, seja ela religiosa, política ou econômica. Como a alienação econômica está na base de todas as outras, a sua abolição envolve todos os outros aspectos.

A abolição é caracterizada por Marx como abolição positiva na medida em que não nega, mas, ao contrário, assimila toda a riqueza do desenvolvimento anterior. Isso pressupõe o reconhecimento de que a propriedade privada é a objetivação da vida humana, ainda que na forma da alienação. Segundo Marx,

A propriedade privada material, imediatamente perceptível, é a expressão material e sensível da vida humana alienada. O seu movimento - a produção e o consumo - é a manifestação sensível do movimento de toda a produção anterior, quer dizer, a realização ou realidade do homem" (Manuscritos de 1844, p. 193).

Para Marx, todas as manifestações de vida dos homens estão atualmente subordinadas ao movimento da propriedade privada. Sendo assim, o comunismo, ou seja, a emancipação, significa a reintegração desse desenvolvimento anterior realizado sob a forma da alienação ao próprio homem. Esse desenvolvimento inclui não apenas a produção material da vida, mas todas as esferas de atividade humana, deste a religião, a arte e a ciência, até a moral, a família, o direito e o Estado. Diz Marx:

A religião, a família, o Estado, o Direito, a moral, a ciência, a arte, etc., constituem apenas modos particulares da produção e submetem-se à sua lei geral. A abolição positiva da propriedade privada, tal como a apropriação da vida humana, constitui portanto a abolição positiva de toda a alienação, o regresso do homem a partir da religião, da família, do Estado, etc., à sua existência humana, isto é, social" (Manuscritos de 1844, p. 193). 
Segundo Marx, de maneira geral, a forma da propriedade é determinada pela relação entre os trabalhadores e as condições de trabalho. Na medida em que as condições de trabalho são separadas dos próprios trabalhadores, transformam-se em propriedade privada ou, mais precisamente, em capital. Para Marx, o capital constitui fundamentalmente a apropriação privada dos meios de produção. A abolição da propriedade privada a que se refere Marx, portanto, se refere aos meios de produção, e não aos meios individuais de consumo. Trata-se de uma transformação radical não apenas do processo de distribuição, mas fundamentalmente do próprio processo de produção. Como explica Marx na Crítica de Gotha,

\begin{abstract}
"é equivocado, em geral, tomar como essencial a chamada distribuição e aferrar-se a ela como se fosse o mais importante. A distribuição dos meios dos meios de consumo é, em cada momento, um corolário da distribuição das próprias condições de produção. E esta é uma característica do modo mesmo de produção. Por exemplo, o modo capitalista de produção repousa no dato de que as condições materiais de produção são entregues aos que não trabalham sob a forma de propriedade do capital e propriedade do solo, enquanto a massa é proprietária apenas da condição pessoal de produção, a força de trabalho. Distribuídos deste o modo os elementos de produção, a atual distribuição dos meios de consumo é uma consequência natural. Se as condições materiais de produção fossem propriedade coletiva dos próprios operários, isto determinaria, por si só, uma distribuição dos meios de consumo diferentes da atual. O socialismo vulgar (e através dele uma parte da democracia) aprendeu com os economistas burgueses a considerar e tratar a distribuição como algo independente do modo de produção, e, portanto, a expor o socialismo como uma doutrina que gira principalmente em torno da distribuição. Uma vez que desde há muito tempo já está elucidada a verdadeira relação das coisas, por que voltar a marchar para trás?" (Crítica de Gotha, p. 233).
\end{abstract}

Assim, a abolição da propriedade privada pressupõe uma nova organização da produção, que tenha como ponto de partida a apropriação social das condições ou meios de produção. Não se trata, portanto, de abolir toda e qualquer propriedade individual. Pelo contrário, trata-se de abolir a forma classista da propriedade, para que seja possível a realização efetiva da propriedade individual. Como afirma Marx no texto final sobre a Comuna:

"A Comuna, exclamam eles, tenciona abolir a propriedade, base de toda a civilização! Sim, senhores, a Comuna tencionava abolir toda essa propriedade de classe que faz do trabalho de muitos a riqueza de poucos. 
Ela aspirava à expropriação dos expropriadores. Queria fazer da propriedade individual uma realidade transformando os meios de produção, terra e capital, agora principalmente meios de escravizar e explorar o trabalho, em meros instrumentos de trabalho livre e associado" (A Guerra Civil na França, Avante, p. 244).

Já aqui fica claro que para Marx a emancipação humana só pode ser a emancipação do indivíduo ou, como veremos adiante, a realização do indivíduo integral. Em momento algum se trata da realização da propriedade coletiva em detrimento da propriedade individual, como insiste o socialismo vulgar até hoje. E em momento algum, tampouco, se trata da abolição da propriedade em geral, como brada o pânico burguês. Trata-se, antes, de uma mudança radical na forma social da propriedade, justamente com o objetivo de realizar a efetiva emancipação do indivíduo. Como afirma Marx, com sua costumeira ironia, no Primeiro Rascunho do texto sobre a Comuna:

\footnotetext{
"Falam em tom depreciativo da ameaça da abolição da 'propriedade' porque a atual forma classista da propriedade - uma forma transitória - é, para eles, a propriedade ela mesma, de modo que a abolição dessa forma significaria a abolição da propriedade. [...] Não sabem sequer que toda forma social de propriedade tem sua própria 'moral', e que a forma de propriedade social que faz da propriedade o atributo do trabalho, longe de criar 'constrangimento morais' individuais, emancipará a 'moral' do indivíduo de seus constrangimentos morais" (Primeiro Rascunho, p. 144)
}

Além disso, a emancipação humana não significa para Marx a dominação da classe trabalhadora sobre o restante da sociedade, mas sim a abolição de todas as classes e, portanto, da própria classe trabalhadora, na medida em que o trabalho deixa de ser um atributo de classe. Isso só é possível na medida em que, para Marx, o trabalho é identificado como a condição fundamental e natural da vida individual e social. Assim, a libertação do trabalho não significa a libertação da classe trabalhadora, e sim a libertação do homem enquanto homem.

É nesse sentido que, no Primeiro Rascunho, Marx identifica a emancipação social como a "libertação do trabalho da usurpação dos monopolistas dos meios de trabalho, sejam esses meios criados pelos próprios trabalhadores ou dados pela natureza" e, consequentemente, como a 
"abolição de todas as classes e, portanto, de toda [dominação de] classe (porque ela não representa um interesse particular, mas a liberação do 'trabalho', isto é, a condição fundamental e natural da vida individual e social que apenas mediante usurpação, fraude e controles artificiais pode ser exercida por poucos sobre a maioria) [...]" (Primeiro Rascunho, p. 131).

Já no texto final, Marx é tão conciso quanto preciso. A condição da emancipação social é

\begin{abstract}
"extirpar os fundamentos econômicos sobre os quais assenta a existência de classes e, por conseguinte, a dominação de classe. Emancipado o trabalho, todo o homem se torna um trabalhador e o trabalho produtivo deixa de ser um atributo de classe." (A Guerra Civil na França, Avante, p. 243).
\end{abstract}

Positivamente, a abolição da propriedade privada significa a apropriação do conjunto das forças produtivas pelos indivíduos associados. E a apropriação dessa produção multiforme significa, concretamente, o desenvolvimento de capacidades humanas correspondentes. Neste sentido, a abolição da propriedade privada é literalmente a restituição do mundo humano e das relações humanas do próprio homem.

"Com a apropriação das forças produtivas totais pelos indivíduos unidos, termina a propriedade privada" (Ideologia Alemã, p. 107).

Antes de tudo, portanto, deve-se grifar o caráter universal da apropriação. Universal tanto no sentido de que inclui o conjunto das forças produtivas, ou seja, uma massa de instrumentos de produção, quanto no sentido de que deve ser apropriada por todos os indivíduos. Marx é enfático: só é possível realizar a verdadeira apropriação individual através da apropriação universal. Como afirma na Ideologia Alemã,

\footnotetext{
"tal apropriação deve necessariamente apresentar um caráter universal correspondente às forças produtivas e ao intercâmbio. [...] Em todas as apropriações anteriores, uma massa de indivíduos permanecia subsumida a um único instrumento de produção; na apropriação por parte dos proletários, uma massa de instrumentos de produção deve ser subsumida a cada indivíduo, e a propriedade a todos. O moderno intercâmbio universal não pode ser subsumido aos indivíduos senão quando for subsumido a todos." (Ideologia Alemã, p. 106).
} 
A apropriação do conjunto das forças produtivas pela totalidade dos indivíduos não é apenas uma apropriação no sentido do ter, ou seja, não deve ser considerada apenas no sentido material. Ao contrário, a universalidade da apropriação se revela também no fato de que, em contato efetivo com o conjunto das forças produtivas, o que inclui também as criações espirituais dos homens, os indivíduos são libertados de suas limitações locais e nacionais e se transforma em indivíduo universal.

\begin{abstract}
"Pelo que já foi exposto, é claro que a verdadeira riqueza espiritual do indivíduo depende da riqueza de suas relações reais. É apenas desta forma que os indivíduos singulares são libertados das diversas limitações nacionais e locais, são postos em contato prático com a produção (inclusive a espiritual) do mundo inteiro e em condições de adquirir a capacidade de desfrute desta multiforme produção do mundo inteiro (as criações dos homens)." (Ideologia Alemã, p. 54)
\end{abstract}

De maneira ainda mais direta e concreta, Marx não deixa dúvidas sobre o significado efetivo da apropriação das forças produtivas pelo conjunto dos indivíduos:

\begin{abstract}
"A apropriação destas forças produtivas nada mais é do que o desenvolvimento de capacidades individuais correspondentes aos instrumentos materiais de produção. A apropriação de uma totalidade de instrumentos materiais de produção é, exatamente por isso, o desenvolvimento de uma totalidade de capacidades nos próprios indivíduos" (Ideologia Alemã, p. 105).
\end{abstract}

Isso significa que a apropriação não pode ser considerada apenas no sentido do ter, apenas no sentido da posse de objetos. A apropriação efetiva da totalidade de forças produtivas, para Marx, implica necessariamente a criação de uma totalidade de capacidades nos próprios indivíduos, ou seja, implica necessariamente a criação do indivíduo integral ou indivíduo social, isto é, o desenvolvimento pleno do indivíduo.

Em resumo, para Marx, a emancipação do homem só é possível através da abolição da propriedade privada, que positivamente significa a apropriação do conjunto das forças produtivas pela totalidade dos indivíduos, que concretamente significa a criação de uma totalidade de capacidades nos próprios indivíduos, isto é, a criação de indivíduos sociais.

Como dizia Marx nos Manuscritos de 1844, se a propriedade privada é a objetivação alienada do homem, a abolição da propriedade privada só pode ser a verdadeira apropriação 
humana. E é nesta verdadeira apropriação humana que consiste a emancipação de que fala Marx.

Entretanto, como insiste Marx ao longo de toda sua obra, sempre se diferenciando radicalmente dos socialistas utópicos, existem condições materiais imprescindíveis para que tal emancipação possa se efetivar.

"O comunismo não é para nós um estado que deve ser estabelecido, um ideal para o qual a realidade terá que se dirigir. Denominamos comunismo o movimento real que supera o estado de coisas atual. As condições desse movimento resultam de pressupostos atualmente existentes" (Ideologia Alemã, p. 52).

Entre esses pressupostos, estão o alto grau de desenvolvimento das forças produtivas, o desenvolvimento de uma classe revolucionária e a revolução social radical.

Segundo Marx, o grau de emancipação possível em cada período histórico é determinado pelo nível de desenvolvimento das forças produtivas. Um desenvolvimento limitado das forças produtivas, pelo fato de não ser capaz de satisfazer toda a sociedade, gera necessariamente uma situação de antagonismo em que uns (uma minoria) se apropriam das forças produtivas enquanto outros (a maioria) são excluídos dessa apropriação e têm de lutar pelo necessário. Isso significa que a propriedade privada e, de par com ela, o Estado e a lei são produtos necessários do desenvolvimento limitado das forças produtivas. Cada grau de emancipação conquistado ao longo da história foi fruto da criação de novas forças produtivas, que permitiram e impulsionaram o revolucionamento do modo anterior de satisfação das necessidades, isto é, da organização social anterior. Porém, até hoje, segundo Marx, toda emancipação conquistada foi limitada justamente porque foi realizada na base de forças produtivas insuficientes:

"os homens atingiram de cada vez um grau de emancipação que lhes era prescrito e permitido, não pelo seu ideal de homem, mas pelas forças produtivas existentes. No entanto, todas as emancipações se realizaram até hoje na base de forças produtivas limitadas, cuja produção, incapaz de satisfazer toda a sociedade, só permitia o progresso se uns satisfizessem as suas necessidades a expensas dos outros, o que dava a uns - a minoria - o monopólio do progresso, enquanto os outros - a maioria - devido à sua luta continua pela satisfação das necessidades mais elementares eram, entretanto (ou seja, até à criação de novas forças produtivas de caráter 
revolucionário), excluídos de todo o progresso. Assim, a sociedade evoluiu sempre no quadro de um antagonismo, o dos homens livres e dos escravos na antiguidade, dos nobres e dos servos na idade média, da bourgeoisie e do proletariado nos tempos modernos" (Ideologia Alemã, v. II, p. 291).

Isso significa, dizendo de maneira mais concreta, que

"somente é possível realizar a libertação real no mundo real e através de meios reais; que não se pode superar a escravidão sem a máquina a vapor e a Mule-Jenny ${ }^{36}$, nem a servidão sem melhorar a agricultura; e que não é possível libertar os homens enquanto não estiverem em condições de obter alimentação e bebida, habitação e vestimenta, em qualidade e quantidade adequadas. A 'libertação' é um ato histórico e não um ato de pensamento, e é efetivada por condições históricas" (Ideologia Alemã, p. 65).

Sendo assim, a superação da propriedade privada só é possível com um altíssimo desenvolvimento das forças produtivas, que segundo Marx já existia na sua época. Sem esse desenvolvimento, a "vontade" de superação da propriedade privada não passaria de uma aspiração ao impossível. Mais ainda, uma tentativa de superação "na base de forças produtivas limitadas" teria como resultado necessário o renascimento da propriedade privada. Nas palavras de Marx:

\footnotetext{
"Enquanto as forças produtivas não tiverem atingido um ponto de desenvolvimento que torne supérflua a concorrência - outra coisa não fariam, portanto, senão fazer renascer a concorrência - para as classes dominadas seria aspirar ao impossível ter apenas a 'vontade' de abolir a concorrência, e de par com ela o Estado e a lei" (Ideologia Alemã, v. II, p. 136-137).
}

Em outra passagem, Marx reafirma que "um grande incremento da força produtiva, ou seja, um alto grau de seu desenvolvimento" é um "pressuposto prático absolutamente necessário" para a libertação do homem, uma vez que, sem isso, ou seja, com um nível produtivo ainda incapaz de satisfazer toda sociedade, "apenas generalizar-se-ia a escassez e, portanto, com a carência, recomeçaria novamente a luta pelo necessário e toda a imundície anterior seria restabelecida". Vale acompanhar a passagem na íntegra:

\footnotetext{
${ }^{36}$ Nome da primeira máquina de tecer automática.
} 
“Essa 'alienação' - para usar um termo compreensível aos filósofos - pode ser superada, naturalmente, apenas sob dois pressupostos práticos. Para que ela se torne um poder 'insuportável', isto é, um poder contra o qual se faz uma revolução, é necessário que tenha produzido a massa da humanidade como massa totalmente 'destituída de propriedade'; e que se encontre, ao mesmo tempo, em contradição com um mundo de riquezas e de cultura existente de fato - coisas que pressupõem, em ambos os casos, um grande incremento da força produtiva, ou seja, um alto grau de seu desenvolvimento; por outro lado, este desenvolvimento das forças produtivas (que contém simultaneamente uma verdadeira existência humana empírica, dada num plano histórico-mundial e não na vida puramente local dos homens) é um pressuposto prático, absolutamente necessário, porque, sem ele, apenas generalizar-se-ia a escassez e, portanto, com a carência, recomeçaria novamente a luta pelo necessário e toda a imundície anterior seria restabelecida" (Ideologia Alemã, p. 50).

O segundo pressuposto é o desenvolvimento de uma classe revolucionária, identificada por Marx com o proletariado industrial. Como afirma na Introdução de 1844, trata-se

\begin{abstract}
"de uma classe com cadeias radicais, de uma classe da sociedade civil que não é uma classe da sociedade civil; de um estamento que é a dissolução de todos os estamentos; de uma esfera que possui um caráter universal por seus sofrimentos universais e que não reclama para si nenhuma justiça especial, porque não se comete contra ela nenhuma injustiça especial, mas a injustiça pura e simples; que já não pode reclamar um título histórico, mas simplesmente o título humano; [...] de uma esfera, enfim, que não pode emancipar-se sem emancipar-se de todas as outras esferas da sociedade e, ao mesmo tempo, emancipar todas elas; que é, numa palavra, a perda total do homem e que, portanto, só pode se recuperar a si mesma através da recuperação total do homem. Esta dissolução da sociedade como um estamento particular é o proletariado" (Introdução de 1844, p. 12-13).
\end{abstract}

Na Ideologia Alemã, Marx reafirma a mesma ideia:

"Esta subsunção dos indivíduos a determinada classe não pode ser superada até que se forme uma classe que já não tenha qualquer interesse particular de classe a impor à classe dominante" (Ideologia Alemã, p. 119).

Como vimos acima, numa passagem do Primeiro Rascunho do texto sobre a Comuna, a emancipação do trabalho não é a defesa de um interesse de classe e, portanto, não representa um interesse particular, justamente na medida em que a libertação do trabalho 
significa a libertação da condição fundamental e natural da vida individual e social. Sendo assim, a emancipação do trabalho em relação a seu caráter de classe significa a emancipação do homem enquanto homem.

Nos Manuscritos de 1844, Marx é incisivo a esse respeito:

\begin{abstract}
"Da relação do trabalho alienado com a propriedade privada também decorre que a emancipação da sociedade da propriedade privada, da servidão, assume a forma política de emancipação dos trabalhadores; não no sentido de só estar em jogo a emancipação destes, mas por essa emancipação abranger a de toda a humanidade. Pois toda servidão humana está enredada na relação do trabalhador com a produção, e todos os tipos de servidão são somente modificações ou corolários desta relação." (Manuscritos de 1844, Trabalho Alienado, p. 170).
\end{abstract}

A emancipação humana assume, segundo Marx, a forma política da emancipação dos trabalhadores, pois esta implica a emancipação de toda a humanidade, na medida em que o trabalho é a condição fundamental e natural da vida individual e social e que, portanto, toda a servidão humana está enredada na relação do trabalhador com a produção. O cerne de toda a teoria de Marx é a atividade humana. O modo como o homem produz a sua vida material é a base de toda a existência humana, pois essa é a base da produção da vida total. As representações, as relações sociais e as formas políticas de dominação são determinadas pelo modo como se realiza a atividade humana vital, o trabalho, e portanto pela relação do trabalhador com a produção. Isso significa que, com a efetivação da emancipação real do homem, o proletariado não estabelece uma nova dominação de classe, mas, ao contrário, ao abolir as classes e as próprias condições da dominação de classe, abole a si mesmo enquanto proletariado, e só então os indivíduos podem se desenvolver integralmente enquanto indivíduos.

O terceiro pressuposto prático para a efetivação da emancipação humana, segundo Marx, é uma revolução, que além de tudo precisa ser radical. Como diz na Ideologia Alemã:

“Ora, tal transformação só se pode operar por um movimento prático, por uma revolução; esta revolução é necessária, entretanto, não só por ser o único meio de derrubar a classe dominante, mas também porque apenas uma revolução permitirá à classe que derruba a outra varrer toda a podridão do velho sistema e tornar-se capaz de fundar a sociedade sobre bases novas" (Ideologia Alemã, p. 109). 
Trata-se, portanto, de uma revolução que não apenas derruba a classe dominante, mas, com ela, derruba também todo o velho sistema e funda a sociedade em bases novas. Por isso Marx chama esta revolução de revolução radical. De maneira mais concreta e sintética:

\footnotetext{
"uma revolução que, de um lado, derrube o poder do modo de produção e de intercâmbio anterior e da estrutura social, e que desenvolva, de outro lado, o caráter universal e a energia do proletariado necessária para a realização da apropriação; e na qual, além disso, o proletariado despoja-se de tudo o que nele ainda resta de sua anterior posição na sociedade" (Ideologia Alemã, p. 106).
}

Já aqui fica claro que, para Marx, a revolução não compreende somente o seu aspecto negativo, ou seja, a destruição das velhas relações, mas também o seu momento positivo, ou seja, o desenvolvimento das condições de apropriação do conjunto das forças produtivas, isto é, o desenvolvimento das capacidades individuais, do indivíduo integral. E, para não restar dúvidas, Marx é categórico ao afirmar que com esta revolução o proletariado despoja-se de tudo o que nele ainda resta de sua anterior posição na sociedade, ou seja, o proletariado deixa de ser proletariado.

\section{Revolução política $X$ revolução social}

Feita essa breve introdução sobre os principais aspectos da emancipação humana para Marx, passamos agora à consideração da relação específica que existe entre a política e a emancipação humana.

O primeiro aspecto a ressaltar é diferenciação entre revolução política e revolução social. Já nas Glosas de 1844, Marx é categórico:

"por parcial que seja uma insurreição industrial, terá sempre uma alma universal, e por universal que seja uma insurreição política terá sempre, sob a mais colossal das formas, um espírito estreito" (Glosas Críticas, p. 519). 
A revolução meramente política é uma revolução parcial, pois deixa em pé os pilares do edifício, ou seja, não age sobre a estrutura da organização social, mas apenas altera quem está no poder ou a forma do Estado, pressupondo sempre o domínio de uma parte da sociedade sobre as demais. Já a revolução social é a revolução radical, que abala os pilares do edifício, ou seja, atua na base da organização social, no modo de produção da vida material e, ao suprimir a propriedade privada, abole as próprias condições da dominação política em geral.

Na Questão Judaica, referindo-se à Revolução Francesa - o caso clássico de revolução política -, Marx afirma que a revolução política não revoluciona a estrutura da organização social, mas, ao contrário, a considera como um pressuposto inteiramente subsistente, como sua base natural. Retomemos as palavras de Marx, já citadas no Capítulo 3, agora com outro foco:

\footnotetext{
"A revolução política dissolve a sociedade civil nas suas componentes sem revolucionar estas componentes e as submeter à crítica. Esta revolução considera a sociedade civil, o mundo das necessidades, o trabalho, os interesses privados e a lei civil como a base da sua própria existência, como um pressuposto inteiramente subsistente, portanto, como a sua base natural" (Questão Judaica, p 62).
}

Limitada e parcial na medida em que deixa em pé os pilares do edifício, a revolução meramente política estabelece o domínio de uma parte da sociedade civil sobre as demais, de uma classe que impõe suas condições específicas como condições gerais da sociedade:

\footnotetext{
"Sobre o que descansa uma revolução parcial, uma revolução meramente política? Sobre parte da sociedade civil que se emancipa e instaura sua dominação geral; sobre uma determinada classe que parte de sua situação especial e empreende a emancipação geral da sociedade. Esta classe emancipa toda a sociedade, mas somente se toda a sociedade se encontra na mesma situação desta classe, ou seja, se possui, por exemplo, o dinheiro e a cultura ou pode adquiri-los a seu bel-prazer" (Introdução de 1844, p. 1011).
}

Se a revolução política reage contra a separação em relação à comunidade política, a revolução social reage contra a separação em relação à comunidade humana. A comunidade política, o Estado, é uma comunidade abstrata e limitada, que está em contraposição ao indivíduo real, enquanto a comunidade humana é a própria vida, a vida física e espiritual, a 
essência humana, a verdadeira comunidade dos homens. Assim, uma revolução política, por maior que seja, será sempre limitada; enquanto uma revolução social, por menor que seja, será sempre universal. A revolução política estabelece a dominação de uma classe sobre o resto da sociedade, enquanto a revolução social abole as condições da dominação de classe.

Sobre a revolução política, Marx afirma:

"A alma política de uma revolução consiste [...] na tendência das classes carentes de influência política a superar seu isolamento em relação ao Estado e ao poder. Seu ponto de vista é o do Estado, o de um todo abstrato, que só existe graças à separação da vida real, que é inconcebível sem a contraposição organizada entre a vida genérica do homem e sua existência individual. Portanto, uma revolução com alma política organiza também, em consonância com a natureza limitada e dual desta alma, um círculo dirigente da sociedade, à custa da sociedade mesma" (Glosas Críticas, p. 520)

Já sobre a revolução social, Marx sustenta:

"Uma revolução social se situa no ponto de vista do todo porque - mesmo que só se produza em um distrito fabril - entranha um protesto do homem contra a vida desumanizada, porque arranca do ponto de vista do indivíduo real, porque a comunidade contra cuja separação do indivíduo este reage é a verdadeira comunidade do homem, a essência humana" (Glosas Críticas, p. 520).

Ou seja,

"a comunidade de que se acha isolado o trabalhador não é uma comunidade política. Esta comunidade, da qual o separa seu próprio trabalho, é a vida mesma, a vida física e espiritual, a moral humana, o gozo humano, a essência humana. A essência humana é a verdadeira comunidade dos homens. E assim como o irremediável isolamento em relação a esta essência é incompreensivelmente mais total, mais insuportável, mais espantoso e mais contraditório que o isolamento em relação à comunidade política, assim também a superação deste isolamento e inclusive uma reação parcial diante dele constitui uma sublevação contra ele muito mais infinita, assim como o homem é mais infinito que o cidadão e a vida humana mais infinita que a vida política. Assim, pois, por parcial que seja uma insurreição industrial, terá sempre uma alma universal, e por universal que seja uma insurreição política terá sempre, sob a mais colossal das formas, um espírito estreito" (Glosas Críticas, p. 519).

A revolução social, portanto, é uma revolução radical na medida em que se volta 
"não só contra as condições particulares da sociedade existente até então, mas também contra a própria 'produção da vida' vigente, contra a 'atividade total' sobre a qual se baseia" (Ideologia Alemã, p. 57).

A revolução social, portanto, é caracterizada como a revolução industrial, no sentido de que atua nos fundamentos da sociedade burguesa, no modo de produção da vida material, e não apenas sobre suas formas políticas. Nas palavras de Marx, trata-se de identificar

"até que ponto essas revoluções põem realmente em causa as relações da vida burguesa, ou até que ponto só atingem as suas formações políticas" (As Lutas de Classes na França, p. 298, grifos meus).

E, segundo Marx, a revolução francesa de junho de 1848 foi a primeira a realmente colocar em xeque não apenas uma forma política de dominação, mas a própria ordem social burguesa.

\footnotetext{
"Nenhuma das inúmeras revoluções da burguesia francesa desde 1789 foi um atentado à ordem, pois deixaram subsistir a dominação de classe, a escravidão do trabalhador, a ordem burguesa, por mais que a forma política dessa dominação e dessa escravidão mudasse. Junho atentou contra esta ordem. Ai de junho!" (Nova Gazeta Renana, p. 128, n. 29).

"E depois de Junho revolução significava: transformação da sociedade burguesa, enquanto antes de Fevereiro tinha significado: transformação da forma de Estado" (As Lutas de Classes na França, p. 233).
}

No mesmo sentido, Marx distingue as lutas revolucionárias das lutas puramente legais, as lutas que agem somente no "terreno do direito" das lutas que atingem "o terreno em que esse direito assenta, a propriedade burguesa" (As Lutas de Classes na França, p. 300). E denuncia o fato de que, ao restringir-se ao terreno do direito, à esfera legal, a luta revolucionária é enfraquecida: "a energia do povo foi afrouxada, este foi habituado a triunfos legais em vez
de revolucionários" (As Lutas de Classes na França, p. 299). 
Ao dirigir suas revoluções somente às formas políticas, à forma de Estado, ao direito etc., o proletariado acaba por perpetuar a sua escravidão, ainda que esta assuma uma forma política diferente.

Entretanto, como veremos mais adiante, ao dirigir a sua luta contra o próprio poder de Estado, e não apenas contra esta ou aquela forma assumida por ele, tal como fez a Comuna de Paris, os trabalhadores colocam-se no terreno revolucionário e põem em xeque o poder do capital. Nas palavras do 18 de Brumário, a partir do momento em que a dominação da classe burguesa se organiza totalmente e adquire a sua expressão política pura, o antagonismo de classe aparece também em sua forma pura, podendo então

\footnotetext{
"assumir aquela versão perigosa que transforma toda luta contra o poder estatal em luta contra o capital" (18 de Brumário, p. 81).
}

\section{O momento político da revolução social: a ditadura do proletariado}

Entretanto, inclusive a revolução socialista necessita de um momento político. Embora o momento político seja de fato imprescindível, corresponde apenas à dissolução e à destruição do velho poder e das velhas relações. Na construção positiva da nova sociedade, a revolução se despoja de sua envoltura política. Trata-se, portanto, de uma prática política orientada para a superação da própria política - ou, no dizer de José Chasin, de uma prática metapolítica.

Na Ideologia Alemã, Marx enfatiza a necessidade do momento político da revolução:

\footnotetext{
"toda classe que aspira à dominação, mesmo que essa dominação, como no caso do proletariado, exija a superação de toda a antiga forma de sociedade e de dominação em geral, deve conquistar primeiro o poder político, para apresentar seu interesse como interesse geral, ao que está obrigada no primeiro momento" (Ideologia Alemã, p. 49).
}

Nas Glosas Críticas, encontramos uma das formulações mais incisivas a esse respeito:

\footnotetext{
"Toda revolução dissolve a velha sociedade, e assim considerada, é uma revolução social. Toda revolução derroca o velho poder, e neste sentido é uma revolução política. [...] A revolução em geral - o derrocamento do
} 
poder existente e a dissolução das velhas relações - é um ato político. E sem revolução não pode realizar-se o socialismo. Este necessita do referido ato político, enquanto necessita da destruição e da dissolução. Mas, ali onde começa sua atividade organizadora, ali onde se manifesta seu fim em si, sua alma, o socialismo se despoja de sua envoltura política" (Glosas Críticas, p. 520).

Isso significa que, segundo Marx, a classe trabalhadora, no primeiro momento, precisa necessariamente se apropriar do poder político e apresentar seu interesse como interesse geral. Mas, então, quer dizer que Marx defende a dominação da classe trabalhadora sobre o resto da sociedade? Essa questão, que costuma causar calafrios nos democratas de esquerda e de direita, é respondida pelo próprio Marx, sem rodeios, em seu Conspecto sobre o livro de Bakunin "Estatismo e Anarquia", escrito em 1874 e 1875.

Perguntemos com Bakunin: “O que significa o proletariado 'organizado como classe dominante'?".

\footnotetext{
"[Marx] Significa que o proletariado - em vez de lutar, fragmentadamente, contra as classes economicamente privilegiadas - adquiriu forças e organização suficientes para aplicar contra elas meios gerais de coerção. Porém, o proletariado pode apenas aplicar meios econômicos que suprimem seu próprio caráter de salariat e, portanto, de classe. Portanto, com sua completa vitória, terminará também sua dominação, pois que desaparecerá seu caráter de classe." (Conspecto, vesão online).
}

Como já observamos acima, a dominação política da classe trabalhadora tem como objetivo a extinção dos fundamentos econômicos da dominação de classe e, portanto, a extinção da própria classe trabalhadora enquanto tal. Uma vez desaparecido seu caráter de classe, termina também a sua dominação. Ou seja, trata-se de um período de transição, em que se exerce uma dominação para se acabar com a própria dominação. Mas de onde vem a necessidade de, nesse primeiro momento, exercer meios gerais de coerção, ou seja, dominação política, sobre as classes economicamente privilegiadas? Por que a classe trabalhadora não pode simplesmente extinguir toda a dominação de imediato? No mesmo Conspecto, Marx dá diversas respostas igualmente categóricas para essa questão. Acompanhemos uma delas:

"[Bakunin] Já afirmamos a nossa profunda oposição à teoria de Lassalle e Marx, que recomenda aos operários, se não como ideal último pelo menos 
como o próximo grande objetivo - a fundação de um Estado popular que, como eles o expressaram, não será nada além do que o proletariado organizado como a classe dominante. Surge a questão: se o proletariado se tornar a classe dominante, sobre quem governará? Isso significa que ainda haverá outro proletariado, que estará sujeito a esta nova dominação, a este novo Estado.

"[Marx] Isso significa que, enquanto as outras classes, especialmente a classe capitalista, continuarem existindo, enquanto o proletariado luta contra ela (pois quando ele alcança o poder do governo, seus inimigos e a velha organização da sociedade ainda não desapareceram), deve empregar meios coercitivos, portanto meios governamentais. Ele próprio é ainda uma classe, e as condições econômicas das quais derivam a luta de classes e a existência de classes ainda não desapareceram e devem ser à força removidas do caminho ou transformadas, sendo esse processo de transformação acelerado pela força" (Conspectus, vesão online, tradução livre do inglês).

Marx não deixa dúvidas: enquanto houver classes, não será possível acabar com a dominação política e, portanto, com a necessidade do emprego da força. Nesse primeiro momento, ou seja, logo que a classe trabalhadora conquista o poder de governo, a burguesia e a velha organização da sociedade ainda não desapareceram, e a própria classe trabalhadora ainda é uma classe. Ou seja, ainda não desapareceram as condições econômicas das quais derivam a dominação de classe e a própria existência das classes. Esse primeiro momento da revolução, identificado com o momento negativo, da destruição das velhas relações, é caracterizado aqui por Marx justamente pela necessidade do emprego da força, ou seja, de meios coercitivos, e portanto governamentais, para acelerar esse processo de extinção das condições econômicas da dominação de classes. Sendo assim, a dominação política, mesmo que seja a dominação da classe trabalhadora, só pode deixar de existir, segundo Marx, quando este fundamento econômico tiver sido completamente varrido junto com as próprias classes.

Justamente por isso, como acontece ao longo de toda a sua obra, Marx enfatiza que essa transição não pode acontecer da noite para o dia, ou seja, que será necessariamente um longo período. De qualquer maneira, o que determina a sua duração não é a simples vontade, mas sim a persistência ou não de seu fundamento econômico. Segundo Bakunin, os marxistas "consolam-se com a ideia de que essa Ditadura será apenas curta e passageira", ao que Marx responde: 
"Non, mon cher! A dominação de classe dos trabalhadores sobre as camadas da velha sociedade que contra ele combatem poderá apenas existir enquanto o fundamento econômico da existência das classes não for eliminado." (Conspecto, vesão online).

Sendo assim, ao contrário do que pode parecer à primeira vista, a crítica de Marx à política não o leva, em absolutamente nenhum momento de sua obra, à recusa ou à indiferença em relação à luta política. Pelo contrário, é ele quem geralmente denuncia isso em outros teóricos, como acontece no Conspecto em relação ao próprio Bakunin. Para Marx, imaginar que uma revolução seria capaz de varrer do dia para a noite toda a forma de dominação política não passa de um sonho piedoso. E isso, justamente por causa do fundamento de sua crítica da política, ou seja, por compreender o vínculo orgânico existente entre as formas de dominação política e as formas de produção da vida material. Assim como a propriedade não pode ser socializada por um decreto, assim também as formas políticas não podem desaparecer sem que desapareça o seu fundamento real. E, para que isso aconteça, é necessário um longo e doloroso parto, durante o qual ainda persistirão inevitavelmente diversos elementos da velha sociedade. Isso, para Marx, significa apenas que a nova sociedade não pode ser criada a partir do nada, de um ideal ou uma vontade piedosa, mas sim a partir das próprias condições reais geradas pela velha sociedade. Com sua ironia costumeira, Marx afirma no Conspecto:

\footnotetext{
"Durante o período da luta para a derrubada da velha sociedade, como o proletariado ainda atua sobre a base dessa velha sociedade, movimentando-se, por isso, também no interior de formas políticas que ainda pertencem mais ou menos a ela, não atingiu ainda, ao longo desse mesmo período de luta, sua complexão definitiva e emprega meios de libertação que deixarão de existir, depois da libertação. Por isso, o Sr. Bakunin conclui que é mais aconselhável não se fazer absolutamente nada... e esperar o Dia da Liquidação Geral - o Dia do Juízo Final." (Conspecto, vesão online).
}

Aqui, é preciso fazer uma observação sobre a expressão utilizada por Marx para designar esse período de transição: a ditadura do proletariado. Para determinar o seu sentido específico, é preciso compreender o que significa ditadura para Marx, nesse contexto.

Em Marx, o termo ditadura tem um sentido muito distinto do que utilizamos atualmente. Para nós, ditadura significa essencialmente um governo não democrático ou 
antidemocrático, sem mecanismos de participação popular e sem liberdades civis ou individuais. Ditadura é hoje o oposto de democracia. Atualmente, portanto, ditadura designa uma forma de governo.

Em Marx, porém, a coisa se passa de maneira bem diferente. O que chamamos hoje de ditadura é o que Marx chamaria de Estado bonapartista. Em nenhum momento, entretanto, Marx opõe o Estado bonapartista à democracia. E por quê? Pois, para Marx, tanto o Estado democrático quanto o Estado bonapartista são formas políticas do domínio da burguesia como classe e, enquanto tais, formas da ditadura da burguesia. Em Marx, portanto, ditadura significa dominação de classe, independentemente da forma política específica que esta venha a assumir.

Assim, por exemplo, nas Lutas de Classes na França Marx se refere à república constitucional de fevereiro de 1848 como "a ditadura burguesa oficialmente reconhecida" (As Lutas de Classes na França, Boitempo, p. 64). República burguesa que, em sua forma pura, se manifesta como "o Estado cujo propósito confesso é eternizar o domínio do capital, a escravidão do trabalho" (As Lutas de Classes na França, Boitempo, p. 64). Neste sentido, a república constitucional é uma forma específica da ditadura burguesa, isto é, do domínio da burguesia enquanto classe e, portanto, da escravização do trabalho pelo capital.

No texto Indiferentismo Político, de 1873, portanto já depois da Comuna de Paris, Marx ironiza aqueles que recusam qualquer forma de luta política, como alguns socialistas e anarquistas de sua época. Nesse texto, a certa altura, Marx opõe explicitamente a ditadura revolucionária dos trabalhadores à ditadura da burguesia e caracteriza a primeira como uma forma revolucionária e transitória do Estado. Colocando ironicamente palavras na boca de seus adversários, Marx afirma:

"Quando a luta política da classe trabalhadora adquire formas violentas, quando os trabalhadores erigem a sua ditadura revolucionária, em vez da ditadura da burguesia, cometem, então, o terrível crime de violação dos princípios, porque, para satisfazer suas necessidades quotidianas, miseráveis e profanas, para quebrar a resistência da burguesia, conferem ao Estado uma forma revolucionária e transitória, em vez de baixar as armas, abolindo o próprio Estado." (Indiferentismo Político, versão online).

A ditadura do proletariado, portanto, é a dominação do proletariado enquanto classe, dominação que só pode ter como objetivo a abolição de todas as classes, inclusive da 
sua própria, e portanto, embora não possa acontecer da noite para o dia, só pode ser transitória. Nas Lutas de Classes na França, referindo-se ao socialismo revolucionário, identificado ao comunismo, em oposição ao socialismo doutrinário, Marx afirma:

\begin{abstract}
"Esse socialismo é a declaração de permanência da revolução, a ditadura classista do proletariado como ponto de transição necessário para a abolição de todas as diferenças de classe, para a abolição da totalidade das relações de produção em que estão baseadas, para a abolição da totalidade das relações sociais que correspondem a essas relações de produção, para a convulsão da totalidade das ideias, que se originam dessas relações sociais." (As Lutas de Classes na França, Boitempo, p. 138-139).
\end{abstract}

Sendo assim, quando afirma que o período de transição socialista assume necessariamente a forma de uma ditadura revolucionária do proletariado, Marx se refere ao fato de que, nesse período o proletariado estará organizado enquanto classe dominante e precisará garantir o seu poder contra as antigas classes dominantes, o que, como vimos, só é possível através da força e, portanto, de maneira política.

Com base nesse esclarecimento, podemos acompanhar a passagem clássica da Crítica de Gotha sobre o tema sem correr o risco de distorcer o seu sentido:

\footnotetext{
"Entre a sociedade capitalista e a sociedade comunista medeia o período da transformação revolucionária da primeira na segunda. A este período, corresponde também um período político de transição, cujo Estado não pode ser outro senão a ditadura revolucionária do proletariado." (Crítica de Gotha, p. 239).
}

Entretanto, é preciso observar que, com essa expressão, Marx não se refere de maneira nenhuma à forma política específica dessa dominação. Ou seja, o que Marx chama de ditadura do proletariado não é uma forma de governo, muito menos uma forma de governo necessariamente antidemocrática, que nega as liberdades civis, mas apenas a dominação do proletariado enquanto classe.

Qual é, então, a forma política específica do governo dos trabalhadores? Marx nunca se propôs a responder essa pergunta, pois, para ele, trata-se de uma questão histórica e não teórica. E foi exatamente o que aconteceu com a Comuna de Paris, o primeiro governo operário da história. Voltaremos à Comuna com mais detalhes no final deste capítulo. Por ora, basta apenas ressaltar que Marx a identifica como um governo da classe operária e, 
mais precisamente, como uma forma política inteiramente nova, descoberta na prática pelos trabalhadores, para realizar a emancipação do trabalho. A Comuna, portanto, segundo Marx, é a forma política específica em se realizou na prática o que ele chamou algumas vezes de ditadura revolucionária do proletariado, isto é, o governo da classe trabalhadora. E, curiosamente, trata-se de uma forma de governo reconhecidamente democrática. Nas palavras de Marx, ainda que isso não fosse o seu alvo último, ainda que isso lhe fosse meramente concomitante, o fato é que a Comuna "fornecia à República a base de instituições realmente democráticas" (A Guerra Civil na França, p. 243). Isso significa que a ditadura revolucionária do proletariado se realizou pela primeira vez na história na forma política democrática representada pela Comuna.

Entretanto, nem a Comuna e nem suas instituições verdadeiramente democráticas são o alvo último de Marx. Como ele enfatiza ao longo de toda a sua obra, o governo da classe trabalhadora não tem como objetivo criar uma nova dominação de classe, mas sim extinguir toda dominação política, até atingir a emancipação econômica do trabalho, que implica necessariamente a liberdade do indivíduo.

\section{Para além da política}

Como vimos, para Marx a emancipação política, mesmo na sua forma mais completa e acabada, a democracia, representa apenas o grau máximo de liberdade possível dentro da sociedade capitalista. Em outras palavras, a emancipação política representa a forma final da emancipação humana sob o domínio do capital. Vale retomar as palavras de Marx já em 1843, na Questão Judaica:

\footnotetext{
"A emancipação política representa, sem dúvida, um grande progresso. Não constitui, porém, a forma final de emancipação humana, mas é a forma final de emancipação humana dentro da ordem mundana até agora existente." (Questão Judaica, p. 47).
}

Em nenhum momento Marx recusa ou se mostra indiferente ao aperfeiçoamento da emancipação política. Porém, também em nenhum momento deixa de ressaltar seus limites intrínsecos. Assim, embora nunca despreze a luta no interior das formas políticas da 
sociedade capitalista e ainda demonstre a inevitabilidade disso inclusive no primeiro momento de um processo revolucionário, Marx é categórico na denúncia dos limites intrínsecos da liberdade política e na afirmação de que o prosseguimento da construção da liberdade humana só pode se dar para além da política e, portanto, para além do capital. Trata-se, portanto, de uma reformulação completa do problema, que exige agora a consideração de uma nova qualidade de liberdade, que só pode ser encontrada para além da política.

\subsection{Contradição radical entre política e liberdade humana}

Como vimos, o Estado é força social alienada, é expressão prático-idealista do poder social, ou seja, do conjunto das forças produtivas, que estão separadas da maior parte dos indivíduos e concentradas nas mãos de uma classe dominante, na qualidade de propriedade privada. Isso significa que o Estado é indissociável da propriedade privada e, por conseguinte, desaparece juntamente com ela. Sendo assim, a apropriação do conjunto das forças produtivas pelos indivíduos associados implica não apenas o desaparecimento da propriedade privada como também, juntamente com ela, o desaparecimento do Estado. Uma vez superada a base do modo de vida atual, supera-se ao mesmo tempo e por consequência o Estado que Ihe corresponde, o direito e a própria necessidade da política. $\mathrm{O}$ controle sobre seu modo de vida é apropriado pelos indivíduos associados, deixando de existir de maneira autônoma, como uma esfera à parte, estranha, enquanto Estado, sob o domínio de uma pequena parcela da sociedade.

Assim, no lugar da comunidade aparente, da comunidade meramente política, estabelece-se a comunidade real, condição para a verdadeira liberdade do indivíduo, ou seja, para o seu desenvolvimento integral. Marx é incisivo: na comunidade real, os indivíduos adquirem a sua liberdade simultaneamente com a sua associação, graças a esta associação e dentro dela. Assim, o Estado, entendido enquanto comunidade meramente política ou comunidade aparente, surge nitidamente como um obstáculo ao livre desenvolvimento do indivíduo. A realização da comunidade real implica necessariamente o desaparecimento da política. Como diz Marx na Ideologia Alemã: 
"A transformação das forças pessoais (relações) em forças objetivas, através da divisão do trabalho, não pode ser abolida extirpando do cérebro essa representação geral, mas unicamente através de uma nova submissão das forças objetivas e da abolição da divisão do trabalho por parte dos indivíduos. Ora, isto não é possível sem a comunidade [suprimido do manuscrito: e sem o completo e livre desenvolvimento do indivíduo que ela implica]; é somente em comunidade [com outros que cada] indivíduo tem os meios necessários para desenvolver as suas faculdades em todos os sentidos; a liberdade pessoal só é, portanto, possível na comunidade. Nos sucedâneos de comunidade que até agora existiram, no Estado, etc., a liberdade pessoal só existia para os indivíduos que se tinham desenvolvido nas condições da classe dominante e somente na medida em que eram indivíduos dessa classe. A comunidade aparente, anteriormente constituída pelos indivíduos, adquire sempre perante eles uma existência independente e, simultaneamente, porque significa a união de uma classe face a uma outra, representa não apenas uma comunidade ilusória para a classe dominada, mas também uma nova cadeia. Na comunidade real, os indivíduos adquirem a sua liberdade simultaneamente com a sua associação, graças a esta associação e dentro dela" (Ideologia Alemã, p. 80).

Em outra passagem, compreendendo o trabalho enquanto a forma negativa da autoatividade, ${ }^{37}$ Marx afirma categoricamente que o Estado está em oposição direta à verdadeira liberdade pessoal, ou seja, à realização da personalidade humana, à realização dos indivíduos enquanto indivíduos. Assim, ao contrário do que reza a vulgata marxista e antimarxista, ao mesmo tempo em que Marx enfatiza o caráter pessoal da liberdade humana, a realização da liberdade plena como liberdade do indivíduo e da sua personalidade, sustenta a incompatibilidade desta com o Estado.

\begin{abstract}
"os proletários, se pretendem afirmar-se como pessoas, devem abolir a sua própria condição de existência anterior, que é simultaneamente a de toda a sociedade até aos nossos dias, isto é, devem abolir o trabalho [como forma negativa da auto-atividade, ou seja, o trabalho assalariado]. Por este motivo, eles encontram-se em oposição direta à forma que os indivíduos da sociedade escolheram até hoje para expressão de conjunto, quer dizer, em oposição ao Estado, sendo-lhe necessário derrubar esse Estado para realizar a sua personalidade" (Ideologia Alemã, v. I, p. 82-83).
\end{abstract}

\footnotetext{
${ }^{37}$ Nesta passagem, Marx explicita o sentido das expressões autoatividade e trabalho, neste contexto: "a vida material aparece como a finalidade, e o criador desta vida material, o trabalho (agora a única forma possível mas, como veremos, negativa, da auto-atividade), aparece como meio" (Ideologia Alemã, p. 104-105).
} 
De acordo com Marx, a conquista da liberdade humana envolve necessariamente a superação do Estado, do direito e de todas as instituições políticas. Ou seja, há uma incompatibilidade radical entre emancipação humana plena, de um lado, e Estado, política e direito, de outro. No que toca ao direito, vale relembrar as palavras incisivas de Marx, ao ressaltar

"a oposição entre o comunismo e o direito, quer se trate do público, do privado ou da sua formulação mais genérica enquanto direitos do homem" (Ideologia Alemã, v. I, p. 265).

Nos Manuscritos de 1844, Marx cita algumas formas de "comunismo grosseiro", ou seja, algumas formulações precárias sobre o comunismo. Entre elas está a seguinte:

\footnotetext{
“O comunismo $\alpha$ ) ainda de natureza política, democrático ou despótico; $\beta$ ) com a abolição do Estado, mas ao mesmo tempo realidade ainda incompleta e afetada pela propriedade privada, isto é, pela alienação do homem" (Manuscritos de 1844, p. 192).
}

Essa é uma das passagens mais condensadas sobre a crítica de Marx à política. Ainda que de maneira muito breve, Marx é categórico na afirmação da incompatibilidade radical entre comunismo e política, seja na sua forma democrática ou despótica. Ao falar de uma forma de comunismo limitada porque ainda de natureza política, Marx deixa claro que o comunismo, em sua formulação correta, não possui natureza política. Isso significa que, para Marx, a discussão sobre se o comunismo é despótico ou democrático não faz o menor sentido, pois para ele o comunismo simplesmente não tem natureza política. Com pouquíssimas palavras, e de maneira negativa, Marx evidencia que o comunismo envolve não apenas a abolição da propriedade privada, como também a abolição da política enquanto tal, o inclui tanto a sua forma despótica quanto a democrática. 


\subsection{Abolição positiva da política: reabsorção das funções legítimas pelo corpo social}

No capítulo da Ideologia Alemã contra Max Stirner, Marx retoma os princípios fundamentais de sua crítica à política ao demonstrar que as instituições políticas só são necessárias no quadro da divisão do trabalho e que a revolução comunista, uma vez que suprime a divisão do trabalho, suprime igualmente as próprias instituições políticas. Com isso, não só se reafirma que as instituições políticas, em geral, são expressão de uma limitação social e são elas próprias limitadas, como também que a superação dessa limitação envolve precisamente o desaparecimento das próprias instituições políticas. Nas palavras de Marx:

\footnotetext{
"Daquilo que atrás dissemos contra Feuerbach [capítulo I], conclui-se que as revoluções até hoje verificadas no quadro da divisão do trabalho conduziram necessariamente a novas instituições políticas; conclui-se igualmente que a revolução comunista, que abole a divisão do trabalho, dá afinal origem ao desaparecimento das instituições políticas" (Ideologia Alemã, v. II, p. 213).
}

Na Miséria da Filosofia e no Manifesto do Partido Comunista, encontramos a sustentação categórica de que a abolição das classes implica a abolição do poder político propriamente dito. Sendo assim, a abolição das classes significa ao mesmo tempo a abolição do Estado político e da sociedade civil, pois implica o surgimento de uma nova forma de associação, sem classes, na qual o poder social não se constitui independentemente da própria sociedade e, portanto, não tem caráter político. Na Miséria da Filosofia, Marx escreve:

"Isto quer dizer que, após a derrocada da velha sociedade, sobrevirá nova dominação de classe, traduzida em novo poder político? Não.

"A condição de emancipação da classe operária é a abolição de todas as classes, do mesmo modo que a condição da emancipação do terceiro estado, da ordem burguesa, foi a abolição de todos os estados e de todas as ordens.

"No transcurso de seu desenvolvimento, a classe operária substituirá a antiga sociedade civil, por uma associação que exclua as classes e seu antagonismo; e não existirá já um poder político propriamente dito, pois o poder político é, precisamente, a expressão oficial do antagonismo de classe, dentro da sociedade civil." (Miséria da Filosofia, p. 165, grifos meus). 
No Manifesto Comunista, Marx é igualmente incisivo:

\begin{abstract}
"Desaparecidas no curso do desenvolvimento as diferenças de classes e concentrada toda a produção nas mãos dos indivíduos associados, o poder público perde o caráter político. Em sentido próprio, o poder político é o poder organizado de uma classe para a opressão de uma outra. Se o proletariado na luta contra a burguesia necessariamente se unifica em classe, por uma revolução se faz classe dominante e como classe dominante suprime pela força as velhas relações de produção, então suprime juntamente com estas relações de produção as condições de existência do antagonismo de classes, as classes em geral, e, com isto, o seu próprio domínio como classe." (Manifesto Comunista, p. 125, grifos meus).
\end{abstract}

A abolição do Estado e do poder político enquanto tal não significa, entretanto, que as funções relativas à comunidade desaparecerão. Pelo contrário, elas serão reabsorvidas pela comunidade real, isto é, pelos indivíduos associados. Sendo assim, mesmo na sociedade comunista continuarão existindo algumas funções sociais análogas às atuais funções do Estado. Como afirma Marx na Crítica de Gotha:

\footnotetext{
"Cabe então a pergunta: que transformação sofrerá o ordenamento estatal [Staatswesen] na sociedade comunista? Ou, em outros termos: que funções sociais, análogas às atuais funções do Estado, subsistirão então? Esta pergunta só pode ser respondida cientificamente, e por mais que combinemos a palavra povo e a palavra Estado, não nos aproximaremos um milímetro da solução do problema." (Crítica de Gotha, p. 239, grifos meus).
}

Note-se que, ao se questionar sobre a sociedade comunista, Marx não usa a palavra Estado (Staat), mas sim ordenamento estatal (Staatswesen). E, para não deixar dúvidas, logo em seguida reformula completamente a questão, perguntando agora sobre as funções sociais, análogas às atuais funções do Estado. Ou seja, se não haverá Estado na sociedade comunista, isso não significa que não haverá funções sociais relativas à comunidade. E, além disso, se não é possível saber previamente quais serão essas funções, ao menos é possível determinar o seu caráter, ou seja, o fato de não terem mais natureza política.

Nas Cisões Fictícias na Internacional, escrito em 1872, Marx é taxativo a esse respeito: 
"uma vez atingido o objetivo do movimento proletário - isto é, a abolição das classes -, desaparece o poder do Estado, que serve para manter a grande maioria dos produtores submetida a uma pequena minoria de exploradores, e as funções do governo se tornam simples funções administrativas" (Cisões Fictícias na Internacional, Avante, II, p. 310, grifos meus).

Com a abolição do poder de Estado, portanto, as funções de governo se transformam em simples funções administrativas. Funções de governo são funções administrativas com caráter político. Simples funções administrativas são funções administrativas despidas de seu caráter político.

No Conspecto, há passagens esclarecedoras a esse respeito, especialmente porque Marx responde sem rodeios a questões específicas colocadas por Bakunin, questões que até hoje assombram o marxismo. Acompanhemos uma dessas passagens na íntegra:

\footnotetext{
"'[Bakunin] Há cerca de quarenta 40 milhões de alemães. Serão, p.ex., todos esses 40 milhões membros do governo?'

[Marx] Certainly! Pois a coisa toda começa com o autogoverno da commune.

'[Bakunin] Todo o povo irá governar e não existirá nenhum governado.'

[Marx] Quando um homem governa a si mesmo, não o faz segundo esse princípio, pois ele é apenas ele próprio e nenhuma outra pessoa.

'[Bakunin] Então, não existirá nenhum governo, nenhum Estado. Porém, se existir Estado, haverá também governados e escravos.'

[Marx] ou seja, apenas se a dominação de classe tiver desaparecido, e não haverá Estado no atual sentido político." (Conspecto, vesão online).
}

Nas palavras incisivas de Marx, a coisa toda começa com o autogoverno da commune, isto é, da comunidade. Pois dizer que as funções comunitárias possuem caráter político significa precisamente que estas funções estão separadas da comunidade, numa instância à parte, estranha à própria comunidade. Por isso sua crítica não se dirige somente ao Estado, mas à política em geral. Em outras palavras, a crítica de Marx não se dirige apenas a uma forma de ser e de fazer política, mas à política enquanto tal, inclusive àquela que é imprescindível enquanto primeiro momento de uma revolução social radical. $\mathrm{O}$ autogoverno da comunidade significa precisamente a reabsorção da força social alienada sob a forma política.

Entretanto, como acontece em todas as passagens do Conspecto e de sua obra, o autogoverno da comunidade não é pensado nunca como uma forma de organização a ser 
implantada a partir de um ideal. Ao contrário, ele possui pressupostos materiais, sem os quais não passa de um sonho piedoso. Trata-se, aqui como em toda a sua obra, de enfatizar o vínculo orgânico existente entre a forma de organanização social e a forma de produção da vida material. Por isso Marx enfatiza, contra Bakunin, que não haverá nenhum Estado e nenhum governo apenas quando a dominação de classe tiver desaparecido, ou seja, apenas depois de desaparecido o seu fundamento real.

E continua: e não haverá Estado no atual sentido político (und es keinen Staat im jetzigen politischen Sinne geben [wird]). Esta frase, que isolada poderia até causar alguma confusão, significa apenas que a abolição do Estado não implica de maneira nenhuma a abolição das funções sociais relativas à comunidade, mas apenas a abolição do seu caráter político. Ou seja, trata-se aqui da mesma questão colocada na Crítica de Gotha sobre quais modificações o Estado sofreria numa sociedade comunista ou, segundo a reformulação do próprio Marx, sobre quais funções sociais, análogas às atuais funções do Estado, subsistirão. No Conspecto, Marx afirma que Bakunin, ao invés de ficar às voltas com "os seus sonhos sobre dominação",

"Deveria perguntar a si mesmo: qual é a forma que as funções de administração poderão assumir, sobre o fundamento desse Estado dos Trabalhadores - se assim o pretende designar?" (Conspecto, versão online).

Essa passagem deixa claro que a questão central, para Marx, é uma mudança na forma assumida pelas funções de administração. Ou seja, continuarão existindo funções de administração ou funções gerais, isto é, funções sociais relativas à comunidade. A abolição do Estado e da política significa "apenas" uma mudança na forma dessas funções, que perdem o caráter político na exata medida em que são reabsorvidas pelo corpo da sociedade. "Apenas" entre aspas pois, como veremos adiante na análise da Comuna, grande parte das funções estatais serão sumariamente suprimidas, restando apenas o que Marx chama de funções legítimas.

Aqui, é preciso fazer uma observação. Ao afirmar que não haverá Estado apenas no atual sentido político, Marx utiliza o termo Estado num sentido mais amplo, com o signficado geral de administração dos interesses coletivos ou funções sociais relativas à comunidade independetemente da forma específica que venha a assumir, seja ela política ou não. Esse 
sentido, raridade absoluta em sua obra, também aparece por exemplo na seguinte passagem da Critica de Gotha:

\begin{abstract}
"O Partido Operário Alemão - pelo menos se fizer seu este programa demonstra como as ideias do socialismo não the deixaram sequer marcas superficiais; pois que, em vez de tomar a sociedade existente (e o mesmo podemos dizer de qualquer sociedade no futuro) como base do Estado existente (ou do futuro, para uma sociedade futura), considera mais o Estado como um ser independente, com seus próprios fundamentos espirituais, morais e liberais." (Crítica de Gotha, p. 238-239).
\end{abstract}

Nessa passagem, Marx reafirma o princípio fundamental de sua crítica da política, conquista original da Crítica de 1843 já desdobrada no primeiro capítulo: o Estado não é um ser autônomo, com bases próprias; a sociedade é base do Estado. A diferença, aqui, está precisamente na extrapolação dessa definição para qualquer sociedade futura, ou seja, Marx não se refere apenas às formas sociais baseadas na propriedade privada, mas também a uma eventual sociedade comunista. E, curiosamente, utiliza a palalvra Estado para se referir também à administração dos interesses públicos nessa sociedade futura.

Isso significa que, assim como Marx utiliza a expressão sociedade civil para designar tanto a sociedade especificamente burguesa como o conjunto das relações materiais de produção independentemente de sua forma histórica específica, aqui, como em outros raríssimos casos, Marx utiliza a palavra Estado no sentido genérico de funções sociais relativas à comunidade indepedentemente de sua forma específica, ou seja, incluindo também a sua forma não política. E isso, grife-se, mesmo após a Comuna de Paris.

Porém, é preciso não perder de vista que, na Crítica de Gotha, exatamente como no caso citado mais acima, nos momentos em que Marx se refere à sociedade comunista ou à sociedade futura, ele não utiliza a palavra Staat (Estado), mas sim Staatswesen, termo que pode ser traduzido, embora ainda não de maneira exata, por ordenamento estatal. ${ }^{38}$

Feita essa observação, voltemos ao Conspecto. A certa altura, Marx apresenta um exemplo que demonstra nitidamente qual é o alvo específico de sua crítica: a eleição. Acompanhemos a sua irônica indignação contra Bakunin:

\footnotetext{
${ }^{38}$ A maioria das edições em língua portuguesa da Crítica do Programa de Gotha, porém, traduzem Staatswesen pura e simplesmente como Estado, o que, além de causar enorme confusão, atesta o desconhecimento generalizado da especificidade da crítica de Marx à política.
} 
"'[Bakunin] Esse dilema dissolve-se facilmente na teoria dos marxistas. Por Governo do Povo, os marxistas entendem' (isto é, Bakunin) 'o Governo do Povo por meio de um número ínfimo de superiores, escolhidos (eleitos) pelo o povo.'

[Marx] Asine! Toda essa baboseira democrática, essa imbecilidade política! A eleição é a forma política que existe até na mais ínfima comuna russa e no artiel. O caráter da eleição não depende do seu nome, mas sim do fundamento econômico, das correlações econômicas, existentes entre os eleitores.

$E$, logo que as funções deixarem de ser políticas: 1. não existirá nenhuma função de governo; 2 . a repartição das funções gerais tornar-se-á questão operacional que não gera dominação; 3 . a eleição não possuirá nada do caráter político atual." (Conspecto, versão online).

Antes de tudo, ressaltemos que Marx qualifica as asneiras de Bakunin como baboseira democrática e imbecilidade política, expressões que têm um único e mesmo sentido: a desconsideração do fundamento material da esfera política, no caso, da eleição. Marx é categórico: o caráter da eleição não depende de seu nome, mas sim do fundamento econômico, das correlações econômicas, existentes entre os eleitores. Ou seja, a eleição não implica necessariamente dominação política, como quer Bakunin. Ao contrário, uma vez abolidas as condições materiais que geram a dominação de classe, ou seja, o fundamento econômico de toda dominação política, a eleição perde o caráter político e, portanto, não gera mais dominação.

A eleição é um exemplo do que acontecerá com todas as funções gerais. E aqui Marx é igualmente incisivo: uma vez abolido o fundamento econômico da dominação de classe, as funções gerais deixarão de ser funções políticas, e isso significa que a sua divisão entre os membros da sociedade será uma simples questão operacional, que portanto não gera dominação. Isso significa, também, que não existirá mais nenhuma função de governo, uma vez que função de governo, para Marx, é uma função administrativa com caráter político, a qual implica necessariamente o uso da força e, portanto, gera dominação política.

Assim, quando falamos em abolição do Estado, é preciso ressaltar, contra os anarquistas, que no Estado há um núcleo insuprimível, constituido justamente pelas funções legítimas, funções gerais ou funções sociais relativas à comunidade, que portanto existirão mesmo numa sociedade futura. Toda a questão, para Marx, concentra-se no fato de que essas funções serão despidas de seu caráter político. Por isso, assim como nos Manuscritos de 1844 Marx falava da abolição positiva da propriedade privada, falamos aqui da abolição positiva da política. E, para falar de abolição da política e reabsorção das forças sociais, nada 
melhor do que trazer à tona a primeira e mais rica experiência histórica nesse sentido: a Comuna de Paris.

\title{
4.3. A Comuna de Paris: forma política não estatal e reabsorção das forças sociais
}

\author{
"Qualquer que seja o andar das coisas no futuro \\ imediato, o certo o é que se conquistou um novo \\ ponto de partida de importância histórico- \\ mundial" (Marx a Ludwig Kugelmann, 17 de abril \\ de 1871 , p. 209).
}

Nos textos sobre a Comuna, ou seja, na Guerra Civil na França e nos dois Rascunhos, encontramos formulações preciosas de Marx sobre a relação entre política e emancipação humana, especialmente no que se refere aos últimos temas desenvolvidos acima: a incompatibilidade radical entre o Estado e a liberdade humana, o momento político da revolução social e, especialmente, a reabsorção das forças sociais pelo corpo da sociedade.

\footnotetext{
"Era esse o seu verdadeiro segredo: ela era essencialmente um governo da classe operária, o produto da luta da classe produtora contra a apropriadora, a forma política, finalmente descoberta, com a qual se realiza a emancipação econômica do trabalho. [...] A dominação política do produtor não pode coexistir com a perpetuação da sua escravidão social. A Comuna havia pois de servir como uma alavanca para extirpar os fundamentos econômicos sobre os quais assenta a existência de classes e, por conseguinte, a dominação de classe. Emancipado o trabalho, todo o homem se torna um trabalhador e o trabalho produtivo deixa de ser um atributo de classe." (A Guerra Civil na França, p. 243).
}

Segundo Marx, a Comuna é a forma política descoberta na prática pelos trabalhadores para levar a cabo a emancipação do trabalho. O alvo efetivo da Comuna, segundo Marx, é a emancipação do trabalho, ou seja, a reorganização radical da sociedade, através da socialização dos meios de produção (terra e capital) e a consequente abolição da dominação de classe em geral. Nesse sentido, ela não foi uma revolução meramente política, mas sim o início de uma revolução social radical, voltada para a emancipação humana geral.

Entretanto, é preciso não confundir a Comuna com a própria emancipação. Mesmo tomado pelo entusiasmo, escrevendo no calor da hora, Marx enfatiza categoricamente, e 
não poucas vezes, o fato de que a Comuna é apenas a forma política da emancipação do trabalho, e não a própria emancipação do trabalho; apenas a alavanca para extirpar a dominação de classe, e não a própria abolição da dominação de classe; numa palavra, apenas o meio, e não o fim. Isso fica particularmente nítido, por exemplo, quando Marx afirma que a Comuna não abole a luta de classes, mas apenas fornece o meio propício para que ela se desenvolva da maneira mais racional e humana até chegar ao seu fim. As palavras de Marx no Primeiro Rascunho não deixam dúvidas a esse respeito:

\begin{abstract}
"Isso é a Comuna: forma política da emancipação social, libertação do trabalho usurpado pelos monopolistas dos instrumentos de trabalho, instrumentos criados pelos próprios trabalhadores ou que são dádivas da natureza. Porém, assim como a máquina do Estado e o parlamentarismo não constituem a vida real das classes dominantes, mas somente organismos gerais pelos quais exercem o domínio, somente garantias e formas políticas da velha ordem das coisas, assim, também, a Comuna não constitui o movimento social de regeneração universal da humanidade, somente o meio organizado de ação. A Comuna não acaba com a luta de classes, por meio das quais as classes trabalhadoras se esforçam para obter a abolição de todas as classes, portanto, de toda a dominação de classe [...] Mas a Comuna propicia o meio racional em que essa luta de classes pode atravessar suas diversas fases de modo mais racional e humano." (Primeiro Rascunho, p. 131, tradução de José Chasin).
\end{abstract}

Assim, a Comuna não significa o fim da luta de classes, mas apenas o meio político encontrado pela classe trabalhadora para levar a cabo essa luta até extirpar completamente os fundamentos da dominação de classe. A Comuna, portanto, não é o objetivo da revolução social, mas apenas o meio organizado de ação, e só é necessária (e possível) enquanto persistirem os fundamentos da sociedade burguesa. Por isso, nas palavras das Glosas de 1844, podemos dizer que a Comuna é uma revolução política com alma social ou, em outra formulação, a primeira experiência histórica do momento político da revolução social. Tratase, portanto, como dizia Marx no Conspecto, do proletariado organizado enquanto classe dominante, com o objetivo de extirpar os fundamentos econômicos da dominação de classe e, consequentemente, a própria dominação de classe em geral.

Vejamos, então, um pouco mais de perto algumas características dessa forma política específica, que evidenciam mais concretamente em que sentido, para Marx, a Comuna 
significa a abolição da maquinaria Estatal e a consequente reabsorção do poder social pela própria sociedade.

\begin{abstract}
"O que é a Comuna, essa esfinge que atormenta o espírito burguês?
"Em sua mais simples concepção, [ela é] a forma sob a qual a classe trabalhadora assume o poder político em seus baluartes sociais, Paris e outros centros industriais" (Segundo Rascunho, p. 168).
\end{abstract}

Não se pode negar que a Comuna representa de fato a tomada do poder pela classe trabalhadora. No entanto, essa tomada de poder tem uma forma peculiar, sem precedentes na história. Isso porque, como enfatiza Marx, a condição para essa tomada de poder é justamente a destruição de sua forma estatal. Acompanhamos duas formulações igualmente esclarecedoras do Segundo Rascunho a esse respeito:

\begin{abstract}
"Mas o proletariado não pode, como o fizeram as classes dominantes e suas diferentes frações rivais nos sucessivos momentos de seu triunfo, simplesmente se apossar desse corpo estatal existente e empregar esse aparato pronto para seu próprio objetivo. A primeira condição para a manutenção do poder político é transformar [a] maquinaria estatal e destruí-la - um instrumento de domínio de classe" (Segundo Rascunho, p. 169).
\end{abstract}

E, logo adiante:

"Mas a classe operária não pode simplesmente se apossar da maquinaria estatal tal como ela se apresenta e dela servir-se para seus próprios objetivos. $O$ instrumento político de sua escravização não pode servir como o instrumento político de sua emancipação" (Segundo Rascunho, p. 169).

Por esse motivo, poucas páginas adiante, no Segundo Rascunho, o próprio Marx reformula a sua resposta inicial à questão sobre o que é a Comuna, ressaltando imediatamente que faz parte da sua natureza a destruição preliminar da velha maquinaria governamental e a sua substituição por um verdadeiro autogoverno da classe trabalhadora:

"Em sua mais simples concepção, a Comuna visava a destruição preliminar da velha maquinaria governamental em suas sedes centrais - Paris e as outras grandes cidades da França - e sua substituição por um verdadeiro autogoverno que, em Paris e nas grandes cidades, bastiões da classe trabalhadora, era o governo da classe trabalhadora" (Segundo Rascunho, p. 172). 
Sendo assim, a Comuna demonstrou na prática que esse primeiro momento da revolução social, esse momento político imprescindível, não pode ser confundido de maneira nenhuma com a apropriação pura e simples do poder estatal tal como ele se apresenta. E isso pelo simples motivo de que, como temos enfatizado ao longo dessa tese, esse poder não é um instrumento neutro de organização da sociedade, mas sim um instrumento forjado e aperfeiçoado justamente para a escravização do trabalho pelo capital. A apropriação e a manutenção do poder político pela classe trabalhadora, portanto, tem como condição primeira a destruição da sua forma estatal. Sendo assim, a Comuna se configura antes de tudo como uma revolução contra o próprio Estado. Nas palavras de Marx no Primeiro Rascunho:

\footnotetext{
"Todas as revoluções anteriores só haviam transferido o poder organizado - essa forma organizada de escravidão do trabalho - de uma mão para a outra. A Comuna não foi uma revolução contra esta ou aquela forma de poder de estado - legitimista, constitucional, republicada ou imperial. Foi uma revolução contra o próprio estado, esse aborto prodigioso da sociedade; foi a retomada pelo povo, para o povo, de sua própria vida social. Não transferiu essa máquina terrível de dominação de classe de uma fração das classes dominantes para outra, mas uma revolução que demoliu a própria máquina. [...] A Comuna foi a negação clara da usurpação estatal, por isso o início da revolução social do século XIX." (Primeiro Rascunho, p. 127, tradução de José Chasin).
}

Em outras palavras, ainda no Primeiro Rascunho:

\begin{abstract}
"Só os trabalhadores, inflamados pelo cumprimento de uma tarefa social nova para toda a sociedade - acabar com todas as classes, com toda a dominação de classe - eram os homens que podiam quebrar o instrumento dessa dominação - o Estado, o poder governamental centralizado e organizado, que, usurpador, se pretende senhor e não servidor da sociedade." (Primeiro Rascunho, p. 128).
\end{abstract}

Mas o que significa, concretamente, demolir a maquinaria estatal? Significa a retomada pelo povo, para o povo, de sua própria vida social, ou seja, a reabsorção do poder de estado pela sociedade. Ainda no Primeiro Rascunho, encontramos uma formulação incipiente no que se refere à forma, mas profundamente esclarecedora no que se refere ao conteúdo, justamente pela sua ênfase no fato de que o poder estatal é a força da própria 
sociedade, porém organizada contra ela mesma, e que, portanto, quebrar o poder estatal implica precisamente a reabsorção dessas forças pela sociedade como suas próprias forças vitais.

"A Comuna - a reabsorção, pela sociedade, pelas próprias massas populares, do poder estatal como suas próprias forças vitais em vez de forças que a controlam e subjugam, constituindo sua própria força em vez da força organizada de sua supressão -, a forma política de sua emancipação social, no lugar da força artificial (apropriada por seus opressores) (sua própria força oposta a elas e organizada contra elas) da sociedade erguida por seus inimigos para sua opressão" (Primeiro Rascunho, p. 129).

Entretanto, é preciso enfatizar que demolir o Estado, para Marx, não significa de maneira nenhuma extirpar toda e qualquer função social relativa à comunidade, que no Conspecto Marx chama de funções gerais e aqui, como na Crítica de Gotha, de funções legítimas. No que se refere à breve existência da Comuna, concretamente, essa destruição do Estado significou, antes de tudo, a amputação de seus órgãos meramente repressivos (polícia e exército) e do funcionalismo estatal, bem como o início do processo de restituição de suas funções legítimas ao corpo da sociedade.

\begin{abstract}
"Enquanto os órgãos meramente repressivos do velho poder governamental [a polícia e o exército] haviam de ser amputados, as suas funções legítimas haviam de ser arrancadas a uma autoridade que usurpava a preeminência sobre a própria sociedade e restituídas aos agentes responsáveis da sociedade." (A Guerra Civil na França, Avante, p. 241).
\end{abstract}

Ou, na formulação do Segundo Rascunho:

\begin{abstract}
"A força governamental de repressão e autoridade sobre a sociedade seria, assim, quebrada em seus órgãos meramente repressivos e, onde houvesse legítimas funções a preencher, estas não seriam exercidas por um corpo superior à sociedade, mas pelos próprios agentes responsáveis da sociedade." (Segundo Rascunho, p. 173).
\end{abstract}

Além da amputação dos órgãos meramente repressivos, Marx se refere também diversas vezes à supressão dos parasitas estatais, isto é, do funcionalismo estatal. Ele 
considera que o Estado moderno constituído tornou-se, além de instrumento de dominação da burguesia enquanto classe, também

"um meio de acrescentar à exploração econômica direta uma segunda exploração do povo garantindo às famílias dessa classe todos os ricos cargos do aparato estatal" (Primeiro Rascunho, p. 126).

No Segundo Rascunho, Marx se refere aos parasitas estatais como uma forma de opressão econômica indireta:

\footnotetext{
"Em oposição à classe trabalhadora, a classe até então dominante, seja qual for a forma em que ela possa apropriar o trabalho das massas, tem um e o mesmo interesse econômico: manter a escravização do trabalho e colher seus frutos diretamente - como proprietário fundiário ou capitalista - ou indiretamente - como parasitas estatais do proprietário fundiário e do capitalista [...]" (Segundo Rascunho, p. 183).
}

Assim, ao acabar com o funcionalismo estatal, a Comuna acaba também com essa forma de exploração econômica indireta do trabalho pelo capital. E ela acaba com o funcionalismo estatal substituindo-o pelos próprios trabalhadores, membros da Comuna, que realizam, como enfatiza Marx, o verdadeiro trabalho de administração, recebendo salários de operários.

\footnotetext{
"Ela inaugura a emancipação do trabalho - seu grande objetivo -, por um lado, ao remover a obra improdutiva e danosa dos parasitas estatais, cortando a fonte que sacrifica uma imensa da produção nacional para alimentar o monstro estatal, e, por outro lado, ao realizar o verdadeiro trabalho de administração, local e nacional, por salários de operários. Ela dá início, portanto, a uma imensa economia, a uma reforma econômica, assim como a uma transformação política." (Primeiro Rascunho, p. 131)
}

A economia financeira é evidente, mas o que significa para Marx essa transformação política iniciada pela Comuna?

Ao transformar as funções públicas, antes propriedade privada de uma corja de parasitas estatais, em funções de trabalhadores reais, agentes comunais responsáveis e revogáveis a qualquer momento, sob a supervisão pública e ganhando salários de operários, a Comuna desmistifica na prática a aura misteriosa e transcendente do poder estatal. 
Acompanhemos as palavras de Marx no Primeiro Rascunho, carregadas com seu ferino sarcasmo:

\begin{abstract}
"Cai a ilusão de que a administração e o governo político seriam mistérios, funções transcendentes, a serem confiadas apenas a uma casta de iniciados - parasitas estatais, sicofantas ricamente remunerados e sinecuristas ocupando altos postos, absorvendo a inteligência das massas e voltando-as contra si mesmas nos extratos mais baixos da hierarquia. Elimina-se a hierarquia estatal de cima a baixo e substituem-se os arrogantes senhores do povo por servidores sempre removíveis, uma responsabilidade de mentira por uma responsabilidade real, uma vez que eles passam a agir continuamente sob supervisão pública. Eles são pagos como operários, 12 libras por mês, o mais alto salário não excedendo 240 libras por ano, uma quantia que, segundo uma autoridade no assunto, o professor Huxley, chega a pouco mais do que $1 / 5$ daquela que satisfaz um secretário do Metropolitan School Boards. Toda a fraude dos mistérios e pretensões do Estado foi eliminada por uma Comuna que consistia em sua maior parte de simples trabalhadores [...] agindo à luz do dia, sem nenhuma pretensão à infalibilidade, sem se esconder atrás de balcões de procrastinação, sem escrúpulos de confessar seus erros no ato de corrigi-los. Fazendo das funções públicas - militares, administrativas, políticas - funções de trabalhadores reais em vez de atributos ocultos de uma casta treinada" (Primeiro Rascunho, p. 130).
\end{abstract}

Quebra-se, portanto, essa faceta da divisão do trabalho, na medida em que as funções públicas deixam de ser propriedade privada de um governo central e se tornam responsabilidade real de trabalhadores reais, membros da sociedade, sob contínua supervisão pública.

"As funções públicas deixaram de ser propriedade privada dos fantoches do governo central. Não só a administração municipal, mas toda a iniciativa exercida até então pelo Estado foi posta nas mãos da Comuna" ( $A$ Guerra Civil na França, Boitempo, p. 57)

Ou, como afirma no Segundo Rascunho:

"A iniciativa em todas as matérias da vida social estava reservada à Comuna. Em uma palavra, todas as funções públicas, mesmo aquelas poucas que caberiam ao governo central, eram executadas pelos agentes comunais e, portanto, estavam sob o controle da Comuna. É um absurdo dizer que as funções centrais - não da autoridade governamental sobre o povo, mas aquela necessária para os anseios gerais e comuns do país - se tornariam impossíveis. Essas funções existiriam, mas os próprios funcionários não poderiam, como na velha maquinaria governamental, 
sobrepor-se à sociedade real, porque suas funções seriam executadas por agentes comunais e, portanto, estariam sempre sob um controle real. As funções públicas cessariam de ser uma propriedade privada conferida a partir de um governo central a controlar suas ferramentas" (Segundo Rascunho, p. 173)

Note-se, aqui, a ênfase de Marx no fato de que as funções centrais, ou seja, as funções públicas que caberiam ao governo central: 1) continuariam existindo, 2) seriam muito poucas e 3) não podem nunca ser confundidas com a autoridade governamental sobre o povo.

Assim, a forma política peculiar constituída pela Comuna de Paris efetivou na realidade o que as revoluções burguesas sempre prometeram em vão: governo barato e instituições verdadeiramente democráticas. Entretanto, enfatizemos com Marx, nem o governo barato e nem a verdadeira democracia eram o seu objetivo final: eram-lhe meramente concomitantes.

"A Comuna fez uma realidade dessa deixa das revoluções burguesas governo barato - destruindo as duas maiores fontes de despesa: o exército permanente e o funcionalismo de Estado. A sua própria existência pressupunha a não existência de monarquia, a qual, pelo menos na Europa, é o lastro normal e o disfarce indispensável da dominação de classe. Ela fornecia à República a base de instituições realmente democráticas. Mas nem governo barato nem 'República verdadeira' eram o seu alvo último; eram-Ihe meramente concomitantes" (A Guerra Civil na França, p. 243).

A finalidade verdadeira da Comuna, segundo Marx, é a abolição da dominação de classe. A Comuna, enquanto forma política, enquanto governo barato e democrático, não é em momento nenhum exaltado e muito menos confundido por Marx com a sua finalidade. Ou seja, a socialização da propriedade privada envolve um longo e doloroso processo que, embora tenha sido iniciado pela Comuna através da demolição do poder estatal, não pode de maneira alguma ser confundido com ela. O próprio Marx reconhece, mesmo no calor da hora, que nas medidas da Comuna não há "nada de socialista a não ser sua tendência" (Primeiro Rascunho, p. 139). Ou seja, está claro para ele que a Comuna representa apenas o meio propício para iniciar um longo processo, que tem como objetivo a abolição do capital e, portanto, das classes e da dominação de classe. 
"As classes trabalhadoras sabem que têm de passar por diferentes fases da luta de classe. Sabem que a substituição das condições econômicas da escravidão do trabalho pelas condições do trabalho livre e associado só pode ser o trabalho progressivo do tempo [...] mediante um longo processo de desenvolvimento de novas condições [...]. Mas elas sabem, ao mesmo tempo, que grandes passos podem ser dados desde já pela forma comunal de organização política e que é chegada a hora de iniciar esse movimento para elas mesmas e para o gênero humano" (Primeiro Rascunho, p. 131132).

Identificada por Marx como forma comunal de organização política, a Comuna, grifese, ainda constitui uma forma política, pois significa precisamente a classe trabalhadora organizada enquanto classe dominante, ou seja, o início de uma longa guerra do trabalho contra os monopolistas dos meios do trabalho, contra o capital (Primeiro Rascunho, p. 140). Porém, não constitui uma forma política estatal. Estado e Comuna são, portanto, para Marx, diferentes formas políticas. Uma vez alcançado o objetivo final, a socialização efetiva da propriedade privada, as classes deixam de existir e, junto elas, a própria Comuna enquanto forma de organização política.

\section{Fechamento}

Essa definição de emancipação enquanto reabsorção das forças sociais pela própria sociedade já se encontra precisa e explicitamente formulada 30 anos antes dos textos sobre a Comuna de Paris, em 1843, na Questão Judaica, em uma passagem que condensa o significado da emcipação humana para Marx, especialmente no que se refere à sua relação com a política. Acompanhemos a passagem na íntegra:

"Toda emancipação constitui uma restituição do mundo humano e das relações humanas ao próprio homem.

"A emancipação política é a redução do homem, por um lado, a membro da sociedade civil, indivíduo independente e egoísta e, por outro, a cidadão, a pessoa moral.

"A emancipação humana só será plena quando o homem real e individual tiver em si o cidadão abstrato; quando como homem individual, na sua vida empírica, no trabalho e nas suas relações individuais, se tiver tornado um ser genérico; e quando tiver reconhecido e organizado as suas próprias forças (forces propres) como forças sociais, de maneira a nunca mais separar de si esta força social como força política." (Questão Judaica, p. 63). 
Como vimos no início, emancipação, em geral, significa para Marx a reabsorção ou restituição do que é humano (do mundo humano e das relações humanas) ao próprio homem, ou seja, daquilo que é próprio do homem mas está separado dele, colocado fora dele como algo estranho, isto é, daquilo que foi alienado. A emancipação é o antídoto para a alienação.

A emancipação política implica a duplicação da existência do homem: por um lado, indivíduo independente e egoísta e, por outro, cidadão abstrato, pessoa moral. Sendo assim, o homem individual só existe na forma do homem egoísta e o homem genérico apenas na forma do cidadão abstrato. Diante disso, Marx não opta por nenhum dos lados, nem por um pretenso equilíbrio entre eles, ou qualquer outra forma de aperfeiçoamento da emancipação política.

A emancipação humana plena seria, portanto, a reabsorção do cidadão abstrato pelo homem real e individual. Ou seja, a emancipação humana só será plena quando o indivíduo real, na sua vida cotidiana, no trabalho e nas suas relações individuais, tiver se tornado um ser genérico. Isso significaria justamente a superação da contradição entre indivíduo e gênero tal como posta na ordem mundana existente. Seria a transformação do homem em real ser genérico, isto é, a criação do indivíduo social.

Como vimos no Capítulo 3, se Marx denuncia a liberdade como direito do homem, não é por ser a liberdade do indivíduo, mas sim deste indivíduo, ou seja, do indivíduo egoísta, tal como existe e é gerado pela ordem mundana existente. Aqui, Marx não deixa dúvidas quanto a isso ao enfatizar até exageradamente que a emancipação do homem é a emancipação do homem real e individual, do homem individual na sua vida empírica, no trabalho e nas suas relações individuais. Em outras palavras, para Marx a emancipação real do homem é a emancipação do homem individual, ou seja, é a liberdade do indivíduo, na sua vida real e cotidiana.

Na última frase dessa passagem, Marx sustenta que a emancipação do homem só será plena quando o homem real e individual tiver reconhecido e organizado as suas próprias forças como forças sociais, de maneira a nunca mais separar de si esta força social como força política. Em referência direta aos termos utilizados por Rousseau, Marx afirma que, na ordem mundana existente, as forças sociais estão separadas do próprio homem como algo estranho a ele. Essas forças sociais alienadas assumem a forma de força política. 
Força política, portanto, é força social alienada, ou seja, separada do próprio homem, do indivíduo real. Sendo assim, a emancipação plena do homem implicaria a efetiva reabsorção das forças sociais, hoje alienadas sob a forma política, pelos próprios indivíduos.

Depois de demonstrar diversas vezes ao longo do texto que se trata de uma insuficiência própria da natureza da emancipação política, ou seja, de uma deficiência intrínseca ao modo político de se emancipar, Marx aponta para uma perspectiva de emancipação que não é mais, e nem poderia ser, de caráter político. Trata-se de uma nova qualidade de emancipação, que transcende os limites da política.

"Somente uma ordem de coisas na qual já não existam classes e antagonismos de classes, as evoluções sociais deixarão de ser revoluções políticas." (Miséria da Filosofia, p. 166).

Assim, o que Marx chama de comunismo, está longe ser algo como o fim da história. Pelo contrário, no dizer do próprio Marx, trata-se do fim da pré-história da humanidade e portanto do início de sua verdadeira história, justamente porque só então o homem adquire o controle consciente sobre a sua própria forma de vida social. Da mesma maneira, o comunismo também está longe de ser para Marx o paraíso na terra, ou a forma definitiva da sociedade humana.

"O comunismo é a forma necessária e o princípio dinâmico do futuro imediato, mas o comunismo não constitui em si mesmo o objetivo da evolução humana - a forma da sociedade humana" (Manuscritos de 1844, p. 205).

Ou seja, o comunismo não é compreendido por Marx como uma formação social sem contradições. Ao contrário, como enfatiza Chasin, a emancipação do homem não é algo que aconteça da noite para o dia e nem de uma vez por todas, mas uma luta infinita do homem contra os estranhamentos:

\footnotetext{
"a revolução social 'não implica o céu na terra, a ausência absoluta de entraves sociais, de estranhamentos, no prosseguimento infinito da humanização daí para a frente, não significa a supressão definitiva de toda ordem de empecilhos na universalização dos indivíduos de uma vez por todas, mas que a vida humano-societária é uma luta infinita contra os estranhamentos, ou seja, essa luta coincide com a infinitude do processo de hominização'" (CHASIN, Rota e Prospectiva de um Projeto Marxista, p. 63).
} 


\section{CONCLUSÃO}

O primeiro e mais evidente resultado desse estudo é a demonstração de que a crítica de Marx à política, embora se encontre esparsa ao longo de seus escritos, possui um caráter bem definido e coerente, que se mantém ao longo de toda a sua obra a partir da Questão Judaica (1843) até a Crítica de Gotha (1875), ainda que em diferentes graus de concretização. A falta de unidade na forma, nesse caso, é acompanhada de uma profunda unidade no conteúdo.

Segundo Marx, a política - e portanto o Estado e o direito em todas as suas formas não é um atributo inerente à vida social. A política é uma forma assumida pelas relações sociais, devido a circunstâncias históricas determinadas e, enquanto tais, transitórias. Sendo assim, a política é tão transitória quanto a propriedade privada e a divisão do trabalho, ou seja, tão transitória quanto a sociedade capitalista. Entretanto, ao mesmo tempo, a política é indissociável da sociedade capitalista. Não depende da vontade do indivíduo ou de um movimento social constituir as suas relações ou suas lutas enquanto relações e lutas políticas. Trata-se de uma necessidade incontornável, determinada pelo fundamento econômico da sociedade capitalista. Enquanto houver propriedade privada e portanto divisão de classes, inevitavelmente haverá política. Isso significa que, sob o domínio do capital, não apenas as relações sociais, mas também as lutas pela superação dessa forma social assumirão necessariamente uma forma política. Vimos no último capítulo como Marx afirma, no enfrentamento com Bakunin, a necessidade incontornável de um momento político da revolução social.

A crítica de Marx à política é de fato radical, na medida em que denuncia os limites intrínsecos e, portanto, intransponíveis da política em geral, o que inclui o Estado e o direito em todas as suas formas, bem como as ilusões teóricas e práticas a seu respeito. Entretanto, a radicalidade dessa crítica não deve ser confundida, de maneira nenhuma, com uma recusa da luta política em geral e nem com o desprezo das conquistas parciais proporcionadas por ela. O aperfeiçoamento da emancipação política, por exemplo através da abolição do censo eleitoral e da conquista cidadania, embora intrinsecamente limitado, não é nunca recusado, nem sequer menosprezado por Marx. O mesmo acontece com a luta mais imediata dos trabalhadores, como pro exemplo pela redução da jornada de trabalho ou por melhores 
salários. Embora seja evidente para Marx que uma jornada de trabalho reduzida e maiores salários não alteram a relação de exploração fundamental do capital pelo trabalho, embora seja evidente que, por melhor remunerado que seja, o trabalho assalariado será sempre uma forma de escravidão, em momento nenhum Marx recusa ou menospreza a luta imediata por salários.

A própria atuação prática de Marx nas lutas sociais de sua época, como no 1848 alemão através da Nova Gazeta Renana e na I Internacional, por exemplo, já seria suficiente para desfazer essa confusão. Porém, seus escritos são igualmente claros a esse respeito. Esse duplo movimento, em que se reconhecem os progressos parciais ao mesmo tempo em que se denunciam os limites intrínsecos das lutas políticas, é uma constante na obra de Marx pelo menos desde a Questão Judaica (1843):

“A emancipação política representa, sem dúvida, um grande progresso. Não constitui, porém, a forma final de emancipação humana [...]" (Questão Judaica, p. 47).

$\mathrm{Na}$ Ideologia Alemã (1846), por sua vez, Marx se refere especificamente à importância da qualidade de cidadãos, isto é, da cidadania para os proletários. Ou seja, mesmo perfeitamente ciente de seus limites intrínsecos, ou seja, mesmo sem alimentar ilusões a seu respeito, Marx não se furta a reconhecer a importância dessa conquista parcial para os trabalhadores. Em resposta a Max Stirner, Marx afirma:

\footnotetext{
“Diga-se de passagem que aquele 'que tem muitos bens' pensa que a qualidade de cidadãos é indiferente aos proletários, depois de ter afirmado que eles têm em princípio essa qualidade, tal como mais atrás pensava que a forma de governo era indiferente aos bourgeois. Os operários dão tanta importância à qualidade de cidadão ativo que, quando a têm, como na América, 'fazem-na valer' e, quando não a têm, querem-na adquirir. Vejamse as negociações dos operários na América do Norte e a história do cartismo inglês e do comunismo e reformismo na França." (Ideologia Alemã, v. I, p. 277).
}

Se, diante das ilusões dos democratas e socialistas franceses e dos equívocos do movimento operário, vimos Marx ressaltar o caráter intrinsecamente limitado das conquistas meramente legais, pelo fato de enfraquecerem a energia revolucionária, diante 
dos anarquistas e dos socialistas de seu tempo Marx defende enfaticamente a importância e a necessidade da luta política, inclusive no seu sentido mais imediato.

Na Miséria da Filosofia (1847), escrita contra Proudhon, Marx dedica o último capítulo inteiro, intitulado "As greves e as coalizões de operários", à demonstração da importância e da necessidade da luta política, voltando-se igualmente contra os socialistas utópicos, como Owen e Fourier, e os economistas políticos. Com sua costumeira ironia, Marx afirma:

\begin{abstract}
"Os socialistas [discípulos de Fourier e Owen] dizem aos operários: não vos unais em coalisões porque, ao fim de contas, que ganhareis? Um aumento de salários? Os economistas nos demonstram até a evidência que os escassos cêntimos que poderíeis ganhar por uns momentos em caso de êxito seriam seguidos de uma baixa definitiva do salário. Hábeis calculadores vos demonstrarão que seriam necessários muitos anos para que o aumento dos salários pudesse compensar, ainda que somente os gastos necessários para $r$ e manter as coalisões. E nós, na qualidade de socialistas, vos diremos que, independentemente dessa questão de dinheiro, com as coalisões não deixareis de ser operários, e os patrões serão sempre patrões, como antes. Portanto, nada de coalisões, nada de política, pois organizar coalisões não significa, por acaso fazer política?" (Miséria da Filosofia, p. 162).
\end{abstract}

Depois de demonstrar que na realidade as coalisões só aumentaram na época, especialmente na Inglaterra, Marx afirma (com enorme otimismo, por sinal):

\footnotetext{
"Nessa luta - verdadeira guerra civil - vão-se unindo e desenvolvendo todos os elementos para a batalha futura. Ao chegar a esse ponto, a coalisão toma caráter político. [...] Os interesses que defende convertem-se em interesse de classe. Mas a luta de classe contra classe é uma luta política" (Miséria da Filosofia, p. 164).
}

Nessas passagens, Marx sublinha a importância "das greves, da coalisões e de outras formas nas quais o proletariados efetua, ante nossos olhos, sua organização como classe", para refutar aqueles que, como Proudhon e os socialistas de seu tempo, diante dessas lutas "fazem alarde de um desdém transcendental" (Miséria da Filosofia, p. 164).

Logo em seguida, entretanto, seguindo o duplo movimento característico de sua crítica, Marx demonstra que, embora a luta de classes tenha que assumir necessariamente a forma política, isso não significa de maneira nenhuma que, após a derrocada do capitalismo 
"sobrevirá nova dominação de classe, traduzida em novo poder político", tema que já desenvolvemos no Capítulo 5. Aqui, interessa-nos justamente a ênfase dada por Marx à importância das lutas imediatas e parciais, assim como a reafirmação categórica de seu caráter político como uma necessidade incontornável da sociedade capitalista:

\begin{abstract}
"Não digais que o movimento social exclui o movimento político. Não existe, jamais, movimento político que, ao mesmo tempo, não seja social. "Somente uma ordem de coisas na qual já não existam classes e antagonismos de classes, as evoluções sociais deixarão de ser revoluções políticas." (Miséria da Filosofia, p. 166).
\end{abstract}

Mais tarde, no texto Indiferentismo Político (1873), Marx se dirige com profunda ironia àqueles que recusam toda a luta política dos trabalhadores, seja por aumento de salário, seja pela redução da jornada de trabalho, especialmente Proudhon e seus discípulos, John Francis Bray, um discípulo de Owen, e os anarquistas. Marx abre o texto colocando diversas frases na boca dos partidários do indiferentismo político, de maneira profundamente sarcástica. Acompanhemos algumas delas:

\footnotetext{
"Os trabalhadores não devem fazer greves, pois, nelas, dissipam as suas forças, visando a alcançar um aumento de seus salários ou impedir a sua redução, reconhecendo assim, portanto, o sistema de trabalho assalariado, e isso está em contradição com os eternos princípios da emancipação da classe trabalhadora! [...]

"Os trabalhadores não devem dissipar as suas forças, lutando pela obtenção do limite legal da jornada de trabalho, pois isso significa celebrar acordos com os empresários que, então, podem ainda os explorar por 10 ou 12 horas, em vez de 14 ou 16.

"Os trabalhadores não devem formar nenhum sindicato específico para cada uma das profissões, porque, assim, eternizam a divisão social do trabalho - tal qual existe na sociedade burguesa.

"Em uma palavra: os trabalhadores devem cruzar os braços, não desperdiçando seu tempo com movimentos econômicos e políticos.

"Todos esses movimentos não lhes pode proporcionar nada senão resultados imediatos.

"Como pessoas verdadeiramente religiosas, devem desprezar suas necessidades do dia-a-dia, proclamando em alta voz, inteiramente persuadida: "Nossa classe pode ser crucificada, podendo perecer a nossa raça, porém os princípios eternos hão de permanecer imaculados!" (Indiferentismo Político, versão online).
}

Em relação aos pais do socialismo, Marx afirma: 
"Os primeiros socialistas - Fourier, Owen, Saint-Simon etc. - tiveram de se limitar à elaboração de sonhos sobre a sociedade modelo do futuro, pois que as relações sociais ainda não estavam suficientemente desenvolvidas, para possibilitar à classe trabalhadora sua formação como partido político, sendo levados a condenar todas as tentativas, empreendidas pelos trabalhadores - tais quais greves, coalizões, ações políticas -, visando a melhorar em algo a sua situação." (Indiferentismo Político, versão online).

Em relação a um de seus discípulos, Bray, Marx afirma:

"Em um de seus capítulos sobre a ineficiência de todos os meios de cura que se pretendem alcançar através da luta atual, Bray formula uma crítica amarga, dirigida tanto contra os movimentos econômicos quanto contra os movimentos políticos dos trabalhadores ingleses.

"Condena o movimento político, as greves, a redução da jornada de trabalho, a regulação do trabalho fabril das mulheres e das crianças, porque, em seu parecer, tudo isso, em vez de nos conduzir para fora da atual situação social, tão somente nos acorrenta a ela, apenas aguçando ainda mais os seus antagonismos." (Indiferentismo Político, versão online).

Em relação a Proudhon, Marx afirma, por exemplo:

"Para impedir que a classe trabalhadora saia de sua situação assim denominada de humilhação social, o mestre Proudhon execra as coalizões que estruturam a classe trabalhadora em classe que se posiciona de modo hostil em face da respeitável categoria dos senhores de fábrica, empresários, burgueses - categoria essa que, certamente, do mesmo modo que Proudhon, prefere a polícia do Estado ao antagonismo de classe."

"Os ataques do mestre Proudhon apresentavam-se tão ao gosto da burguesia que o The Times concedeu a honra a Proudhon de traduzi-lo, em 1866, por ocasião da grande greve dos alfaiates de Londres, para condenar os grevistas, com as próprias palavras de Proudhon." (Indiferentismo Político, versão online).

Depois de ironizar profundamente esses partidários do indiferentismo político, e exatamente como fez com Bakunin no Conspecto, como vimos no último capítulo, Marx reitera a necessidade incontornável de utilizar os meios de luta efetivamente existentes, ou seja, os recursos internos à própria sociedade capitalista, como as greves, os sindicatos, as negociações para reduzir a jornada de trabalho etc., por mais parciais e limitados que sejam em sua natureza. Aqui, em confronto direto com os anarquistas, Marx qualifica ironicamente esses recursos como condições fatais da luta: 
"todos esses meios de luta têm de ser subtraídos à atual sociedade, uma vez que as condições fatais dessa luta possuem a desgraça de não se adaptarem às fantasias idealistas que esses Doutores das Ciências Sociais erigiram à condição de divindades, sob os nomes deliberdade, autonomia e anarquia. (Indiferentismo Político, versão online).

Mas é no texto conhecido como Salário, Preço e Lucro (1865), originalmente um discurso feito ao Conselho Geral da I Internacional contra um discípulo de Owen, que encontramos as indicações mais claras e diretas a esse respeito, particularmente no que se refere à luta por salários e à atuação dos sindicatos.

Depois de demonstrar que a tendência geral da produção capitalista é a diminuição dos salários e que a luta pela não redução ou pelo aumento destes é inerente à condição dos operários, Marx se pergunta explicitamente sobre a relevância dessa luta. Acompanhemos a passagem na íntegra:

\footnotetext{
"Essas poucas indicações bastam para mostrar que o próprio desenvolvimento da indústria moderna deve progressivamente favorecer o capitalista em detrimento do trabalhador, e que consequentemente a tendência geral da produção capitalista é não aumentar, mas diminuir o nível médio dos salários, ou empurrar o valor do trabalho mais ou menos para seu limite mínimo. Sendo essa a tendência das coisas nesse sistema, isso significa dizer que a classe trabalhadora deveria renunciar sua resistência contra as ingerências do capital e abandonar suas tentativas de obter o melhor resultado possível das chances ocasionais de que dispõe para obter uma melhoria temporária? Se o fizesse, ela se degradaria a uma massa informe de homens famintos e arrasados, sem possibilidade de salvação. Creio haver demonstrado que as lutas da classe operária pelo padrão dos salários são incidentes inseparáveis do conjunto do sistema de trabalho assalariado, que, em $99 \%$ dos casos, seus esforços para elevar os salários são apenas esforços destinados a manter o valor dado do trabalho e que a necessidade de disputar seu preço com o capitalista é inerente à condição dos operários de ter de vender a si mesmos como mercadorias. Caso cedessem covardemente em seu conflito diário com o capital, eles certamente se desqualificariam para a iniciativa de qualquer movimento de maior envergadura." (Salário, Preço e Lucro, p. 77).
}

Aqui, Marx demonstra a necessidade incontornável das lutas por salário, pois, caso os trabalhadores renunciem a ela, se degradariam a uma massa informe de homens famintos $e$ arrasados, sem possibilidade de salvação. Mais do que isso, demonstra que essas lutas são parte inseparável do conjunto do sistema de trabalho assalariado, na medida em que são 
inerentes à condição dos operários de ter de vender a si mesmos como mercadorias. Entretanto, seguindo o duplo movimento que permeia toda a sua obra, depois de afirmar a necessidade e a relevância da luta imediata por salários, Marx faz a seguinte ponderação:

\begin{abstract}
"Ao mesmo tempo, e abstraindo totalmente da servidão geral que o sistema de trabalho assalariado implica, as classes trabalhadoras não devem exagerar para si mesmas o resultado final dessas lutas diárias. Não devem esquecer que estão lutando contra os efeitos, mas não contra as causas desses efeitos; que estão retardando o movimento descendente, mas não alterando sua direção; que estão aplicando paliativos, mas não curando a doença. Não devem, portanto, deixar-se absorver exclusivamente por essas inevitáveis lutas de guerrilhas, provocadas continuamente pelos abusos incessantes do capital ou pelas flutuações do mercado. Elas devem entender que o sistema atual, mesmo com todas as misérias que lhe impõe, engendra simultaneamente as condições materiais e as formas sociais necessárias para uma reconstrução econômica da sociedade. Em vez do lema conservador: 'Um salário justo por uma jornada de trabalho justa!', devem inscrever em sua bandeira a divisa revolucionária: 'Abolição do sistema de trabalho assalariado!'” (Salário, Preço e Lucro, p. 77).
\end{abstract}

Em resumo, se a luta por salários é necessária e inevitável, e seus resultados não são de maneira nenhuma desprezíveis, ao mesmo tempo, as classes trabalhadoras não devem exagerar para si mesmas o resultado final dessas lutas diárias. Assim, se diante dos anarquistas e dos socialistas utópicos Marx enfatiza a necessidade da luta política imediata, diante dos sindicatos, diferentemente, Marx ressalta os limites dessa guerra de guerrilha contra os efeitos do sistema e a necessidade de ir além, lutando contra a sua causa, isto é, usando a sua luta como uma alavanca para a abolição do sistema de salários e, portanto, para a superação do sistema capitalista.

\footnotetext{
"Os sindicatos [Trade Unions] funcionam bem como centros de resistência contra as investidas do capital. Fracassam parcialmente por um uso não judicioso do seu poder. Fracassam geralmente por se limitarem a uma guerra de guerrilha contra os efeitos do sistema existente, em vez de simultaneamente o tentarem mudar, em vez de usarem as suas forças organizadas como uma alavanca para a emancipação final da classe operária, isto é, para a abolição última do sistema de salários" (Salário, Preço e Lucro, p. 78).
}

Diferentemente do otimismo da Miséria da Filosofia, como vimos acima, aqui, ao mesmo tempo em que reconhece a eficácia dos sindicatos como centros de resistência 
contra as investidas do capital, e portanto como uma luta essencialmente defensiva, Marx condena a sua ação justamente por se limitar a uma guerra de guerrilha contra os seus efeitos, ao invés de agir sobre a sua causa.

Aqui, a ponderação que importa ressaltar é apenas a seguinte: não exagerar e portanto não se iludir com os resultados das lutas imediatas não implica de maneira nenhuma, pelo menos não para Marx, a recusa ou o desprezo dessas lutas. Trata-se, não de recusá-las ou desprezá-las, mas de incansavelmente denunciar seus limites para levá-las além.

A crítica de Marx, portanto, não se dirige à luta política enquanto tal, mas sim à luta meramente política, que se restringe às formas políticas, à luta política sem alma social. E só tem alma social a luta política que atinge não apenas o terreno do direito, as formas políticas, mas também o seu fundamento social, ou seja, a dominação da classe burguesa e, consequentemente, o fundamento da sociedade capitalista.

Entretanto, no contexto atual, muito mais inóspito que o de Marx, em que toda a luta social tem se restringido à perspectiva da socialdemocracia tal como descrita por Marx no 18 de Brumário, ou seja, à reivindicação de instituições democráticas, não como meio de suprimir dois extremos, o capital e o trabalho assalariado, mas como meio de atenuar a sua contradição e transformá-la em harmonia, por mais que ela seja ornada com concepções mais ou menos revolucionárias - nesse contexto sombrio, é imprescindível denunciar os limites das lutas diárias e reafirmar a necessidade da revolução social. E, para tanto, como sustenta Chasin, a crítica de Marx à política surge como condição incontornável.

\footnotetext{
"À época de Marx, a superação da Economia Política foi a condição de possibilidade do pensamento científico, o acesso para o exame de rigor da sociabilidade.

“Hoje, para o mesmo fim, é necessário renovar a superação da política, que Marx efetuara na transição de seu pensamento original (1843/1844). A superação da política é a condição necessária da reposição do imperativo da revolução social." (CHASIN, "Ad Hominem - Rota e Prospectiva de um Projeto Marxista", 2000).
} 


\title{
REFERÊNCIAS BIBLIOGRÁFICAS
}

\author{
I. Obras de Marx
}

MARX, Karl e outros. Trabalhadores, uni-vos!: antologia política da I Internacional. São Paulo: Boitempo, 2014.

MARX, Karl. A Burguesia e a Contra-Revolução. São Paulo: Ensaio, 1987.

MARX, Karl. A Guerra Civil em França. In: MARX; ENGELS. Obras Escolhidas. Lisboa: Avante, 1983, tomo II.

MARX, Karl. A Guerra Civil na França. São Paulo: Boitempo, 2011.

MARX, Karl. A Questão Judaica. In: Manuscritos Económico-Filosóficos. Lisboa: Edições 70, 1993.

MARX, Karl. As Lutas de Classes em França de 1848 a 1850. In: Obras Escolhidas. Lisboa: Avante, 1982, tomo I.

MARX, Karl. As Pretensas Cisões na Internacional. In: Obras Escolhidas. Lisboa: Avante, 1983, tomo II.

MARX, Karl. Carta a Annenkov. In: A Sagrada Família. São Paulo: Grijalbo, 1976.

MARX, Karl. Carta a W. Liebknecht, de 6 de abril de 1871. In: MARX; ENGELS. Correspondencia. México: Edições de Cultura Popular, 1977.

MARX, Karl. Chapter 47. Genesis of Capitalist Ground-Rent. In: Capital, v. 3, parte 4.

Disponível em: <https://www.marxists.org/archive/marx/works/1894-c3/ch47.htm>. Acesso em: 22 nov 2016.

MARX, Karl. Comentários ao Livro de Bakunin "Estatalidade e Anarquia". Disponível em: <http://www.scientific-socialism.de/FundamentosMarxEngelsLuta1874.htm>. Acesso em: 23 nov 2016.

MARX, Karl. Conspectus of Bakunin's Statism and Anarchy. Disponível em: <http://www.scientific-socialism.de/FundamentosMarxEngelsLuta1874.htm>. Acesso em: 23 nov 2016.

MARX, Karl. Contribuição à Crítica da Filosofia do Direito de Hegel - Introdução. In: Manuscritos Econômico-Filosóficos. Lisboa: Edições 70, 1989.

MARX, Karl. Crítica ao Programa de Gotha. In: Textos. São Paulo: Edições Sociais, 1975, v. I. 
MARX, Karl. Crítica da Filosofia do Direito de Hegel - Introdução. In: Temas de Ciências Humanas, v. 2, São Paulo: Grijalbo, 1977.

MARX, Karl. Crítica do Programa de Gotha. São Paulo: Boitempo, 2012.

MARX, Karl. Extracto dos Comentários ao Livro de Bakúnine "Estatalidade e Anarquia". In: Obras Escolhidas. Lisboa: Avante, 1983, tomo II.

MARX, Karl. Formações Econômicas Pré-Capitalistas. Rio de Janeiro: Paz e Terra, 1981.

MARX, Karl. Glosas Críticas al Artículo "El Rey de Prusia y la Reforma Social. Por un Prusiano". In: Carlos Marx e Frederico Engels: obras fundamentales. México, Fondo de Cultura Económica, 1987, vol. 1.

MARX, Karl. Grundrisse: manuscritos econômicos de 1857-1858. São Paulo: Boitempo, 2011.

MARX, Karl. Manuscritos Econômico-Filosóficos. In: Manuscritos Econômico-Filosóficos. Lisboa: Edições 70, 1989.

MARX, Karl. Marx a Ludwig Kugelmann, 17 de abril de 1871. In: A Guerra Civil na França. São Paulo: Boitempo, 2011.

MARX, Karl. Miséria da Filosofia. São Paulo: Grijalbo, 1976.

MARX, Karl. 018 de Brumário de Luís Bonaparte. São Paulo: Boitempo, 2011.

MARX, Karl. O Capital. Rio de Janeiro: Bertrand Brasil, 1996. 3v.

MARX, Karl. Prefácio de 1859 a Para a Crítica da Economia Política. In: Marx. São Paulo: Nova Cultural, 1987. (Col. Os Pensadores).

MARX, Karl. Primeiro Manifesto do Conselho Geral da Associação Internacional dos Trabalhadores sobre a guerra franco-prussiana. In: Marx; Engels. Obras Escolhidas. São Paulo: Alfa-Ômega, [s/d], v. 2

MARX, Karl. Primeiro Rascunho. In: A Guerra Civil na França. São Paulo: Boitempo, 2011.

MARX, Karl. Salário, Preço e Lucro. In: Obras Escolhidas. Lisboa: Avante, 1983, tomo II.

MARX, Karl. Segundo Rascunho. In: A Guerra Civil na França. São Paulo: Boitempo, 2011.

MARX, Karl. Sobre o Indiferentismo Político. Disponível em: <http://www.scientificsocialism.de/FundamentosMarxEngelsLuta18721873Indiferentismo.htm>. Acesso em: 23/11/2016.

MARX, Karl. Troca, Igualdade, Liberdade [trecho dos Grundrisse]. In: Temas de Ciências Humanas, v. 3, São Paulo: Grijalbo, 1978. 
MARX, Karl; ENGELS, F. A Ideologia Alemã. Lisboa: Presença/Martins Fontes, 1980, 2v.

MARX, Karl; ENGELS, F. A Ideologia Alemã: (I - Feuerbach). São Paulo: Hucitec, 1984.

MARX, Karl; ENGELS, F. A Sagrada Família. São Paulo: Boitempo, 2003.

MARX, Karl; ENGELS, F. A Sagrada Família. São Paulo: Grijalbo, 1976.

MARX, Karl; ENGELS, F. Manifesto do Partido Comunista. In: Obras Escolhidas. Lisboa: Avante, 1982, tomo I.

\section{Demais obras}

ARTOUS, Antoine. Marx, l'État et la politique. Paris: Sillepse, 1999.

ASSUNÇÃO, Vânia Noeli Ferreira de. Pandemônio de Infâmias: classes sociais, estado e política nos estudos de Marx sobre o bonapartismo. Tese (Doutorado em Ciências Sociais). São Paulo, PUC-SP, 2005.

BOITO JR., Armando (org.). A Comuna de Paris na História. São Paulo: Xamã, 2001.

BRECHT, Bertolt. Os Dias da Comuna. In: Teatro Completo. Rio de Janeiro: Paz e Terra, 1993, v. 10.

COGGIOLA, Osvaldo. Escritos sobre a Comuna de Paris. São Paulo: Xamã, 2002.

COTRIM, Lívia Cristina de Aguiar. Marx: Política e Emancipação Humana: 1848-1871. Tese (Doutorado em Ciências Sociais). São Paulo, PUC-SP, 2007.

CHASIN, José. Ad Hominem: rota e prospectiva de um projeto marxista. In: Ensaios Ad Hominem. São Paulo: Ad Hominem, 2000, n. 1, tomo III (Política).

CHASIN, José. Ensaios Ad Hominem. São Paulo: Ad Hominem, 2000, n. 1, tomo III (Política).

CHASIN, José. Marx: a determinação onto-negativa da politicidade. In: Ensaios Ad Hominem. São Paulo: Ad Hominem, 2000, n. 1, tomo III (Política).

CHASIN, José. Marx: Estatuto Ontológico e Resolução Metodológica. Posfácio. In: TEIXEIRA, F. J. Pensando com Marx. São Paulo: Ensaio, 1995.

CHASIN, José. O Futuro Ausente. In: Ensaios Ad Hominem. São Paulo: Ad Hominem, 2000, n. 1, tomo III (Política).

DEUS, Leonardo Gomes de. Soberania Popular e Sufrágio Universal: o pensamento político de Marx na Crítica de 43. Dissertação (Mestrado em Filosofia). Belo Horizonte, FAFICHUFMG, 2001. 
DRAPER, Hal. The "dictatorship of the proletariat" from Marx to Lenin. Nova lorque: Monthly Review, 1987.

ENDERLE, Rúbens Moreira. Ontologia e Política: a formação do pensamento marxiano de 1842 a 1846. Dissertação (Mestrado em Filosofia). Belo Horizonte, 2000.

ENGELS, F. Introdução à edição de 1891 de A Guerra Civil na França. In: Textos. São Paulo: Edições Sociais, 1975, v. I.

ENGELS, Friedrich; KAUTSKY, Karl. O Socialismo Jurídico. São Paulo: Ensaio, 1991.

FINE, Robert. Democracy and the rule of law: Marx's critique of the legal form. Caldwell: Blackburn Press, 2002.

GOULD, Roger V. Insurgent Identities: class, community and protest in Paris from 1848 to the Commune. Chicago/Londres: Chicago University Press, 1995.

KURTZ, Robert. Os últimos combates. Petrópolis: Vozes, 1997.

LENIN, V. I. O Estado e a revolução: o que ensina o marxismo sobre o Estado e o papel do proletariado na revolução. São Paulo: Hucitec, 1987.

LISSAGARAY, H. Prosper-Olivier. História da Comuna de 1871. São Paulo: Ensaio, 1995.

LUKÁCS, G. Ontologia do Ser Social: os princípios ontológicos fundamentais de Marx. São Paulo: Ciências Humanas, 1979.

MASCARO, Alysson Leandro. Estado e forma política. São Paulo: Boitempo, 2013.

MÉSZÁROS, István. Filosofia, ideologia e ciência social: ensaios de afirmação e negação. São Paulo: Ensaio, 1993.

MÉSZÁROS, István. Marx: a teoria da alienação. Rio de Janeiro: Zahar, 1981.

MÉSZÁROS, István. O poder da ideologia. São Paulo: Ensaio, 1996.

PASUKANIS, Eugeny Bronislanovich. A teoria geral do direito e o marxismo. Rio de Janeiro: Renovar, 1989.

POGREBINSCHI, Thamy. O Enigma do político. Rio de Janeiro: Civilização Brasileira, 2009.

RIHS, Charles. La commune de Paris 1871: sa structure et ses doctrines. Paris: Seuil, 1973.

ROSSI, M. La Génesis del Materialismo Histórico: el joven Marx. Madrid: Alberto Corazón, 1971.

ROUGERIE, Jacques. La commune de 1871. Paris : PUF, 1988. 
ROUGERIE, Jacques. Le procés des communards. Paris: Julliard, 1964.

ROUGERIE, Jacques. Paris libre 1871. Paris: Seuil, 1971.

RUBEL, Maximilien. Crônica de Marx. São Paulo: Ensaio, 1991.

TARTAKOWSKY, Danielle. As análises tradicionais e a bibliografia recente sobre a Comuna. In: BOITO JR., Armando (org.). A Comuna de Paris na História. São Paulo: Xamã, 2001.

TOMBS, Robert. The war against Paris, 1871. Nova lorque: Cambridge University Press, 1981.

VAISMAN, Ester. A Determinação Marxiana da Ideologia. Tese (Doutorado em Filosofia). Belo Horizonte, Faculdade de Educação-UFMG, 1996.

VALLÈS, Jules et al. Crônicas da Comuna. São Paulo: Ensaio, 1992. 